DOE/EI/219.52-. T1

$\mathrm{DOE} / \mathrm{EI} / 21952--\mathrm{T} 1$

DE92 006541

\title{
Coal Reserves Data Base Report
}

Final Report on the

Demonstrated Reserve Base (DRB) of

Coal in Wyoming

FCO1-90EI 21952

Prepared by

Richard W. Jones and Gary B. Glass

The Geological Survey of Wyoming

December 5, 1991

DISTHIBUTHON OF: THIS DOOUMENA IS UNLIMITED MASTER 
Coal Reserves Data Base Report

Final Report on the Demonstrated Reserve Base (DRB) of Coal in Wyoming

Prepared by

Richard W. Jones and Gary B. Glass The Geological Survey of Wyoming

in cooperation with the U.S. Department of Energy,

Energy Information Administration Coal Division

Cooperative Agreement DE-FG01-90EI21952

December 5, 1991 


\section{Table of Contents}

Section

Page

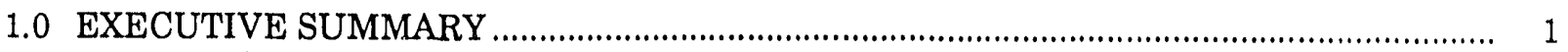

2.0 INTRODUCTION

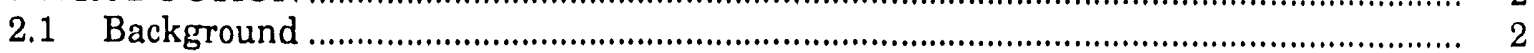

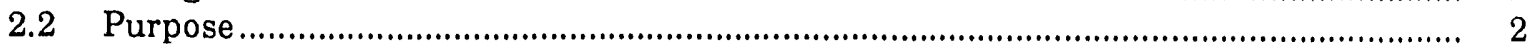

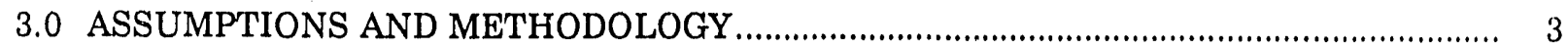

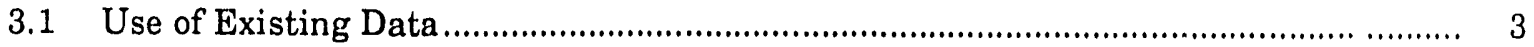

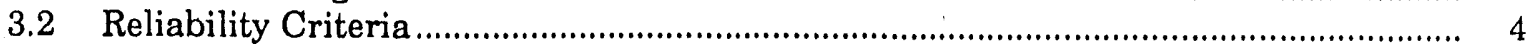

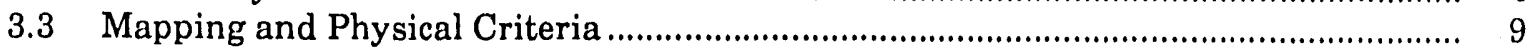

S.4 Selection and Integration of Coal Quality Data ............................................................ 9

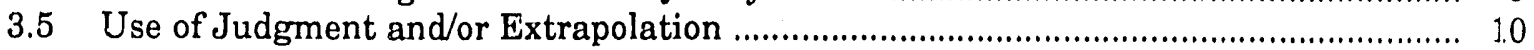

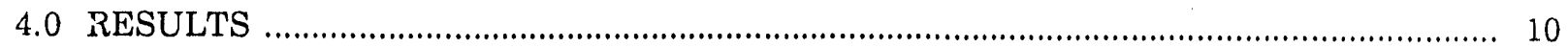

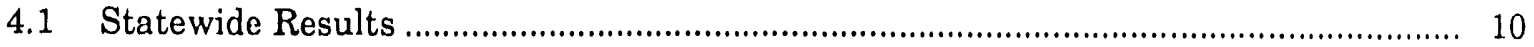

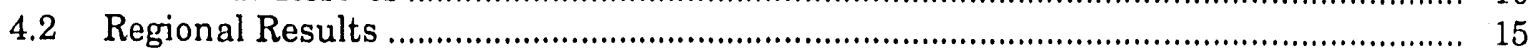

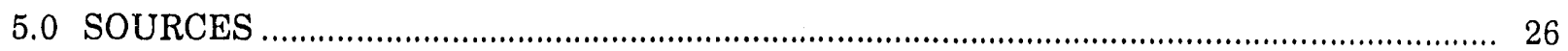

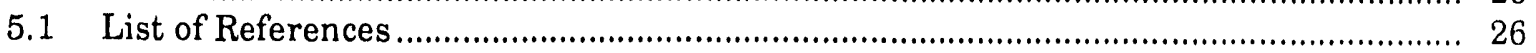

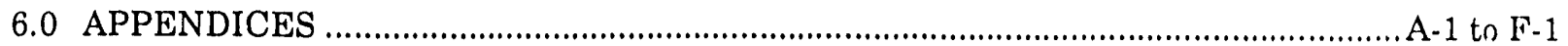

Appendix A. Dave Johnston strippable deposit ............................................................... A-1

Appendix B. Wyodak-Caballo Creek strippable deposit ..................................................

Appendix C. Other strippable deposits in the Powder River Coal Field ............................... C-1

Appendix D. Adaville Formation strippable deposits ...................................................... D -1

Appendix E. Strippable deposits in the Green River Coal Field ....................................... E-1

Appendix F. Strippable deposits in the Hanna and Bighorn Coal Fields .............................. F-1

\section{List of Tables}

Table 1. Estimated original and remaining demonstrated reserve base (DRB) of strippable coal in Wyoming, through December 31 , 1990 (in millions of short tons). Numbers in parentheses are negative

Table 2. Summary of the GSW's estimate of remaining demonstrated reserve base (DRB) of strippable coal deposits in Wyoming coal fields through December 31, 1990 (in million short tons)

Table 3A. Summary of GSW's estimated economic resources of strippable coal in Wyoming, as of January 1, 1991 (in million short tons)

Table 3B. Summary of GSW's estimate of minable reserve base (MRB) of strippable coal in Wyoining, as of January 1, 1991 (in million short tons).

Table 3C. Summary of GSW's estimate of recoverable strippable coal in Wyoming, as of January 1, 1991 (in million short tons) 
Table 4A. Summary of EIA's estimated economic resources of underground coal in Wyoming, as of January 1, 1991 (in million short tons)...........

Table 4B. Summary of EIA's estimate of minable reserve base of underground coal in Wyoming, as of e'anuary 1, 1991 (in million short tons).

Table 4C. Summary of EIA's estimate of recisverable underground coal in Wyoming, as of January 1, 1991 (in million short tons)

Table 5. EIA coal reserves data base - data matrix

\section{List of Figures}

Figure 1. Index map of Wyoming coal fields and location of strippable coal deposits 


\subsection{EXECUTIVE SUMMARY}

The Geological Survey of Wyoming's new estimate of the remaining demonstrated reserve base (or estimated economic resources) of strippable coal in Wyoming, through December 31, 1990 (or, as of January 1, 1991), is 26.998 billion short tons. This new estimate also incorporates an analysis of all available sulfur contents and heating values appropriate for characterizing the State's remaining strippable coal reserves. These analytical data were used in conjunction with the revised demonstrated reserve base to allocate coal reserves to categories of sulfur content and Btu value. This new allocation places 5.2 billion short tons, or 19.2 percent, of the demonstrated strippable reserve base in Wyoming into the Energy Information Administration's lowest sulfur category, $(\leq 0.40$ pounds sulfur/million Btu). It also places 2.6 billion short tons, or 9.8 percent, of the demonstrated reserve base of strippable coal in Wyoming into the Energy Information Administration's highest sulfur category ( $>2.50$ pounds sulfur/million Btu).

The Geological Survey of Wyoming evaluated accessibility for mining in the areas of the demonstrated reserve base of strippable coal, and derived an estimated "minable reserve base" of 26.351 billion short tons. This tonnage, adjusted by various local recovery factors, yields estimated strippable reserves, or "recoverable coal," of 23.314 billion short tons.

The demonstrated reserve base for underground mining was not analyzed as part of this study, but previously derived estimates of the Energy Information Administration were updated to reflect depletion adjustments based on recent mining. The adjusted data, as of January 1, 1991, for underground coal resources include 42.545 billion short tons in the demonstrated reserve base, 38.290 billion short tons in the minable reserve base, and 22.974 billion short tons of recoverable coal. 


\subsection{INTRODUCTION}

2.1 Background. The Coal Reserves Data Base (CRDB) Program is a cooperative data base development program sponsored by the Energy Information Administration (EIA). The objective of the CRDB Program is to involve knowledgeable coal resource authorities from the major coal-bearing regions in EIA's effort to update the Nation's coal reserves data. This report describes one of two prototype studies to update Statelevel reserve estimates.

The Geological Survey of wyoming (GSW) entered into Cooperative Agreement DEFG01-90EI21952 with the U.S. Department of Energy, Energy Information Administration, to update reserve estimates for Wyoming. The 12-month project began on September 5, 1990, and ended on September 4, 1991. This project used funds furnished by the EIA and the GSW.

The CRDB uses an updated set of criteria designed to be nationally consistent but flexible. This program is needed because the traditional source of EIA coal reserve estimates, the demonstrated reserve base (DRB) of coal, is adapted from older published studies from various contributors. Many of the older published studies followed somewhat different criteria than those preferred for the DRB. Further, those studies did not usually contain point source data and coal characterization data that are needed for current coal reserve evaluations.

2.2 Purpose. The CRDB data are intended for use in coal supply analyses and to support analyses of policy and legislative issues. They will be available to both Government and nun-Government analysts. The data also wili be part of the information used to supply United States energy data for international data bases and for inquiries from private industry and the public.

The EIA recognizes that maps of coal beds and deposits, drilling records, historical mine maps, site specific analytical data, and structural geology are critical to reliable characterizations of coal reserves. These types of data have been used to various extents in the current study, as described in the following sections. In accordance with the terms of this prototype study, the supporting information and detailed documentation will remain with the GSW, where it will serve as the basis for future updates and revisions by the technical staff who developed the data. 
The information in this report was compiled under guidelines that emphasize utilization of readily available coal resource and coal analytical data that can be assimilated during a short-term (12-month) project. This GSW project addresses only the revision of the the CRDB for strippable coal deposits in Wyoming. The resulting State-level data base for strippable coal deposits conforms to the criteria of a CRDB Phase I level of effort. Data on underground-minable coal deposits are based on the EIA underground DRB, and on EIA coal quality allocations and accessibility and recovery rate adjustments. They are included in this report in order to present in one place the complete summary of data, updated to the base year 1991, that EIA currently has available in Wyoming for analyses of coal supply.

A Phase II level of effort may be indicated in Wyoming to recalculate the DRB for specific strippable coal deposits and to recalculate, using updated information, the quantities and quality of coal deposits for underground mining. This would be optional and predicated on EIA priorities and funding availability. Phase II projects would permit development of updated coal resource and reserve estimates and coal characterizations that draw on available but previously unused data that would require relatively extensive analysis. This level of effort will especially benefit areas currently lacking in reliable or complete coal reserve data, which includes many of the major strippable and all of the underground coal deposits in Wyoming. No Phase II projects are authorized at this time.

\subsection{ASSUMPTIONS AND METHODOLOGY}

3.1 Use of existing data. With some minor exceptions, no recalculation or redelineation of strippable coal resources was attempted during this Phase I study. Coal resources or reserves added to previous estimates were based on reinterpretation or correction of errors in existing data. Revised coal recovery factors for some coal deposits resulted in new estimates of depleted resources. The revised DRB tonnages were allocated to appropriate categories of sulfur content and heating value on the basis of all the coal quality data available to the GSW. The EIA term "estimated economic resources" was specified in this project to indicate resource quantities that may result from special procedures and/or data in order to calculate an estimate that is considered equivalent to measured and indicated in reliability. Since all resource mapping data used are, in fact, believed to be measured and indicated under conventional U.S. Geological Survey critcria, the estimated econominic resources in this study are wholily 
equivalent to a demonstrated reserve base, or DRB, and the two terms are used interchangeably.

Estimates of original, in-place DRB quantities for each strippable coal deposit in Wyoming were compiled, where possible, from the original published sources (Table 1). Revisions, corrections, and additions to the original sources of data are also noted on Table 1. Section 5.0 SOURCES (below) lists all references used to compile Table 1 and the rest of this report, plus other reports on individual strippable deposits. Section 4.0 also discusses specific problems and/or corrections in the data used to compile this report. Production and mining losses in Table 1 for those strippable deposits (or coal beds within a deposit) that have had significant amounts of coal mining were calculated using recovery factors appropriate to the specific deposit rather than using a statewide average. The remaining DRB for each coal deposit (or coal bed) was calculated by subtracting production and mining losses from the original DRB.

All the strippable deposits in Wyoming, which occur in five of W'yoming's ten coal fields, were evaluated by GSW, using its own data, judgments, and calculations (see Figure 1 and Section 6.0 APPENDICES). In the Powder River Coal Field, nine specific strippable coal deposits were examined, including the Dave Johnston deposit (Appendix A), the Wyodak-Caballo Creek deposit (Appendix B), and seven other deposits (Appendix C). Two strippable coal deposits in the Hams Fork Coal Field (Appendix D), seven strippable deposits in the Green River Coal Field (Appendix E), four strippable deposits in the Hanna Coal Field, (Appendix F), and one strippable deposit in the Bighorn Coal Field (Appendix F) were examined. Each report on a strippable deposit(s) contains a detailed discussion of the data sources used, assumptions and methodology, and a description of any revisions to previous coal reserve estimates.

Estimates of coal resources and reserves for underground mining were not calculated by GSW. The estimates of underground DRB and the associated minable reserve base and recoverable coal (reserves), are based on EIA data and derivations (Energy Information Administration, 1989), updated to January 1, 1991, with depletion adjustment for limited deep mining from 1987 through 1990.

3.2 Reliability Criteria. Only estimates of coal tonnages considered to be in the "demonstrated" reliability category (includes both measured and indicated coal reserve base) were used in this study. However, chemical analyses from data points beyond the 
Table 1. Estimated original and remaining demonstrated reserve base (DRB) of strippable coal in Wyoming, through December 31, 1990 (in millions of short tons). Numbers in parentheses are negative.

Strippable Deposit/ Original Production \& Pomaining Coal Beds Strippable DRB Mining Losses Strippable DRE

References

\section{Powder River Coal Field}

Dave Johnston/Glenrock

$\begin{array}{lr}\text { Badger } & 9.5 \\ \text { School } & 126.2\end{array}$

subtotal all beds

9.5

135.7

$(6.6)$

$(85.4$

$(92.0)$

$(1,473.7)$

$17,526.3$

- $\quad(1,012.6)$

$-$

$(1,473.7)$

$19,360,5$

subtotal Wyodak

Felix

Lower UIm

Scott

C'

'

C subtotal entire deposit

26.3

$1,060.0$

43.8

13.5

11.1

115.2

$20,630.4$

Canyon
Canyon

184.9

Dry Cheyenne

$F$

179.5

Lake DeSmet/Healy Lake DeSmot/Healy

Other Wasatch Fm. coals subtotal all beds

210.0

$1,000.0$

Acme-Keenbum

Monarch \& Dietz\#3

125.0

(45.7)

79.3

Glass, 1985

Spotted Horso

Truman 74.5

Pamell $\quad 30.6$

$\begin{array}{ll}\text { Scott } & 17.9\end{array}$

Daly 11.2

Folix 821.3

Other Ft. Union Fm. cools $\quad 58.3$

Other Wasatch Fm. coals

Smith

subtotal all bods

4.8

178.0

$1,196.6$

Sussex

Fort Union Fm, coals

13.6

$-$

13.6

Smith and others, 1972

Wyamo-Verona

PK

UIm 1

UIm 2

200.0

543.0

990.0

Other Wasatch Fm. coals subtotal all beds

67.0

$1,800.0$

$\begin{array}{lr}- & 74.5 \\ - & 30.6 \\ - & 17.9 \\ - & 11.2 \\ - & 821.3 \\ - & 58.3 \\ - & 4.8 \\ - & 178.0 \\ - & 1,196.6\end{array}$

178.0

74.5

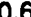

11.2

21.3

58.3

Kent and others, 1977

Kent and others, 1977
Smith and others, 1972

Kent and others, 1977 and

) Haddock and others, 1976

Glass, 1985

Smith and others 1972

Coal fiold total $\quad 25,255 . ? \quad(1,611,4) \quad 23,654,3$

Smith and others, 1972

Smith and others, 1972 Jones and Glass, this report Grazis, 1977

Grazis, 1977

Mapel, 1959, and Smith and others, 1972

Smith and others, 1972

$$
\text { 2 }
$$

Smith and others, 1972

Smith and others, 1972 
South Haystack

Adaville Fm, coals

$1,000.0$

(130.3)

869.7

Smith and others, 1972

Coal field total

64.9

64.9

Cumberland Coal Co., 1977

1,064

$(130.3)$

934.6

Red Desert

Hadsell 2

Battle 283

39.8

Green River Coal Field

Sourdough, Monument, \& Tiemey

Creston 283

458.9

125.6

Latham $3 \& 4$

70.7

subtotal all bods

733.1

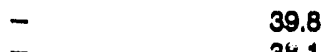

458.9

$\begin{array}{ll}- & 125.6 \\ - & \end{array}$

\begin{tabular}{l}
- \\
$-\quad 70.7$ \\
\hline
\end{tabular}

733.1
Smith and others, 1972

Smith and others, 1972

Smith and others, 1972

Smith and others, 1972

Smith and others, 1972

\section{Creston-Cheroke日}

Cherokee B\&C

Other Fort Union Fm. coals $\quad 159.1$

subtotal all bods

\begin{tabular}{rr}
- & 200.9 \\
- & 159.1 \\
\hline
\end{tabular}

Smith and others, 1972

Jones and Glass, this report

Northem Little Snake River

Fort Union \& Lanco Fm.

$\frac{\text { Mesaverde Fm. coals }}{\text { subtotal all beds }}$

223.

269.6

250.0

(98.8)

(5.8)

$\begin{array}{r}223.6 \\ -\quad 46.0 \\ \hline\end{array}$

168.0

151.2

Smith and others, 1972

Almond Fm. coals

79.2

48.8

17.6

145.6

Fort Union Fm. coals

Lance Fm. coals

Almond Fm. coals

subtotal all bods
(42.1)

(2.2)

(57.1)
60.0

Almond Fm. coals

Coal fiold total

$1,986.3$

Hanna Coal Field

Corral Creok District Medicine Bow Fm. cosls Almond Fm. coals subtotal all bods

Carbon Mining District Hanna Fm. coals

(45.4)

Hanna Mining District Hanna Fm. coals

$\begin{array}{rrr}1.1 & - & 1.1 \\ 16.0 & - & 16.0\end{array}$

17.1

Sominoo Priining District 


\begin{tabular}{lrrrr}
$\begin{array}{l}\text { Hanna Fm. coals } \\
\text { Ferris Fm. coals }\end{array}$ & $\begin{array}{r}5.3 \\
233.2\end{array}$ & $\begin{array}{r}5.3 \\
(36.9)\end{array}$ & $\begin{array}{r}\text { Glass and Roberts, } 1979 \\
\text { Glass and Roberts, 1979 }\end{array}$ \\
\hline subtotal all bods & 238.5 & $(39.9)$ & 201.6 & \\
\hline Coal field total & 648.4 & $(82.3)$ & 566.1
\end{tabular}

Grass Creok

Bighorn Coal Field

\begin{tabular}{llllll} 
Fort Union Fm. coals & 18.6 & $(0.6)$ & 18.0 & Glass and others, 1975 \\
\hline Coal feld total & 18.6 & $(0.6)$ & 18.0 & \\
\hline Grand total, all coal fields $28,983.8$ & $(1,986.3)$ & $26,997.5$
\end{tabular}
Additional reserves determined by planimetering orginal isopach map of Wyodak coal bed by
Smith and others, 1972 .

Reserves in Caballo Creok area determined by planimetering original isopach map of Wyodak coal bed by Smith and others, 1972.

Reserves added in Caballo Creek area to replace those subtracted above.

Based on a percentage of the entire reserve within 1,000 foet of the surface in the demonstrated category for that coal bed.

Local coal beds below the Smith coal bed.

Local coal beds above and below the Felix coal bed. 


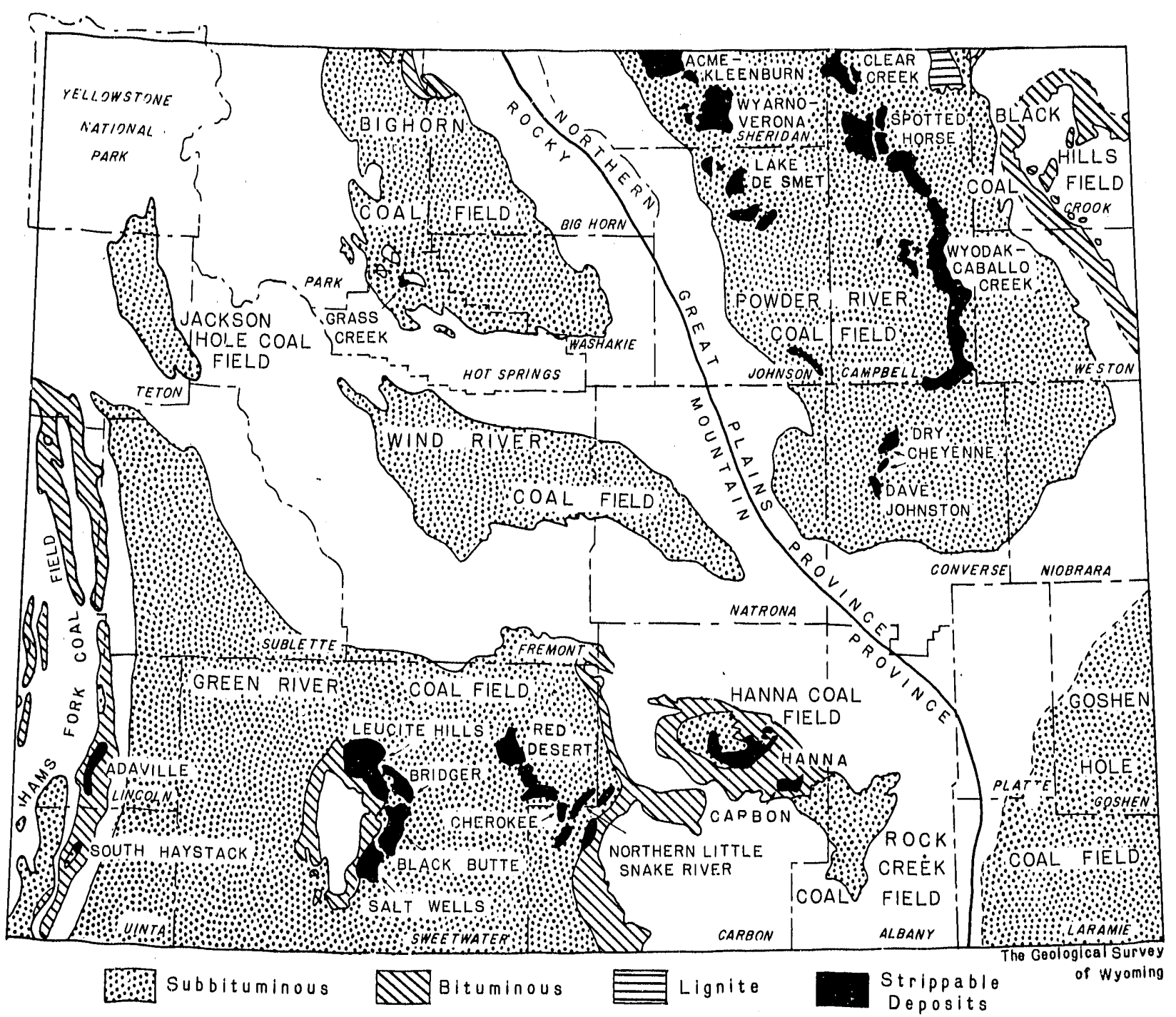

Figure 1. Index map of Wyoming coal flelds and location of strippable coal deposits. 
boundaries of demonstrated reserves were also used to place the reserves into categories of coal quality. In areas of intensive drilling, such as in mine permit areas and within detailed coal exploration projects, the number and spacing of data points was assumed to be sufficient for characterization of the demonstrated reserves without using data points beyond the explored areas. All data sources for this study that used measured, indicated, and demonstrated reserve base definitions are believed to be consistent with U.S. Geological Survey Circular 891 (Wcod, and others, 1983).

3.3 Mapping and Physical Criteria. All mapping and physical criteria for tonnage estimates are given in the sources used to compile the DRB for each strippable coal deposit. Criteria for classifying reserves as "strippable" are those in the original references and the criteria vary from one coal field to another and in many instances vary between :oal deposits within a coal field. No additional or new physical criteria or strippable coal definitions were introduced in this report.

3.4 Selection and Integration of Coal Quality Data. Information on coal quality came from site specific data from drill holes, outerops, and mines; tipple and delivered coal analyses; mine permit and coal development projects; and both publicallyavailable and proprietary data available in the GSW files. The proprietary data were aggregated or averaged to avoid disclosure of individual data. The type of sampling represented by these data ranges from small, incremental coal analyses from coal cores to delivered coal quality data representative of millions of tons of coal produced during several years. Only analyses on an "as-received" or "as-delivered" basis were used in this report. Analyses used to characterize the coal in a particular deposit included solitary sulfur analyses and/or heating values, short proximate analyses, standard proximate analyses, or ultimate and proximate analyses plus heating values. Questionable data or data that could not be l vated accurately in a geographic or stratigraphic sense were not used. Coal analyses derived from weathered, burned, or oxidized coal beds and from significant non-coaly materials present in sampled coal beds were not used to characterize a coal deposit. The reliability of the coal quality data as it pertains to a specific coal deposit is discussed in the individual reports on strippable deposits (Section 4.0 RESULTS).

Coal beds, groups of coal beds, or coal zones in each coal deposit were assigned to an appropricice category of sulfur content and heating value used by the EIA for resource and reserve characterization. Sulfur contents and heating values for an individual coal 
bed, a group of related coal beds, or a coal zone were determined by one of several methods, described below, depending on the coal deposit. The different methods are considered compatible for resource characterization, even though different levels of reliability and accuracy may exist.

In some deposits, variation in sulfur contents and heating values of a coal bed(s) or coal zone was determined by constructing iso-sulfur and iso-Btu maps and calculating the percentage of the total resources contained in a particular coal quality category. This method is best suited for coal deposits with a large number of coal analyses and a wide range of sulfur contents and heating values.

In other coal deposits, coal quality variation within a coal bed(s) or coal zone was not large enough to assign more than one coal quality category to the resources. The data that was used included aggregated data from detailed ind:istry development projects (based on hundreds or thousands of coal analysee from drill holes and/or historical coal production and delivery data), numerous coa'! analyses from regional exploration programs, or widely-spaced coal analyses from reconnaissance-type exploration programs. Average or weighted average sulfur contents and heating values were determined and each coal bed(s) or coal zone was assigned tc an appropriate coal quality category. In all cases, the available coal quality data are considered representative of production attainable from resources and reserves.

3.5 Use of Judgment and/or Extrapolation. For all coal deposits evaluated in this report, professional judgment was used in both the resource assessment techniques and in determining the reliability and usefulness of the available data. Resource estimation methods and projections of data used in this study are discussed in the reports on each strippable deposit (see Section 4.0 RESULTS).

\subsection{RESULTS}

4.1 Statewide Results. A summary of the revised DRB of strippable coal in Wyoming, by coal field and category of coal quality, through December 31,1990 , is given in Table 2. This table was compiled from the reports for individual coal deposits (Table 1, above, and Appendices A through F below). All the GSW estimates of demonstrated strippable reserve base can be equated with "estimated economic resources". 
Table 2. Summary of the GSW's estimate of remaining demonstrated reserve base (DRB) of strippable coal deposits in Wyoming coal fields, through December 31, 1990 (in million short tons).

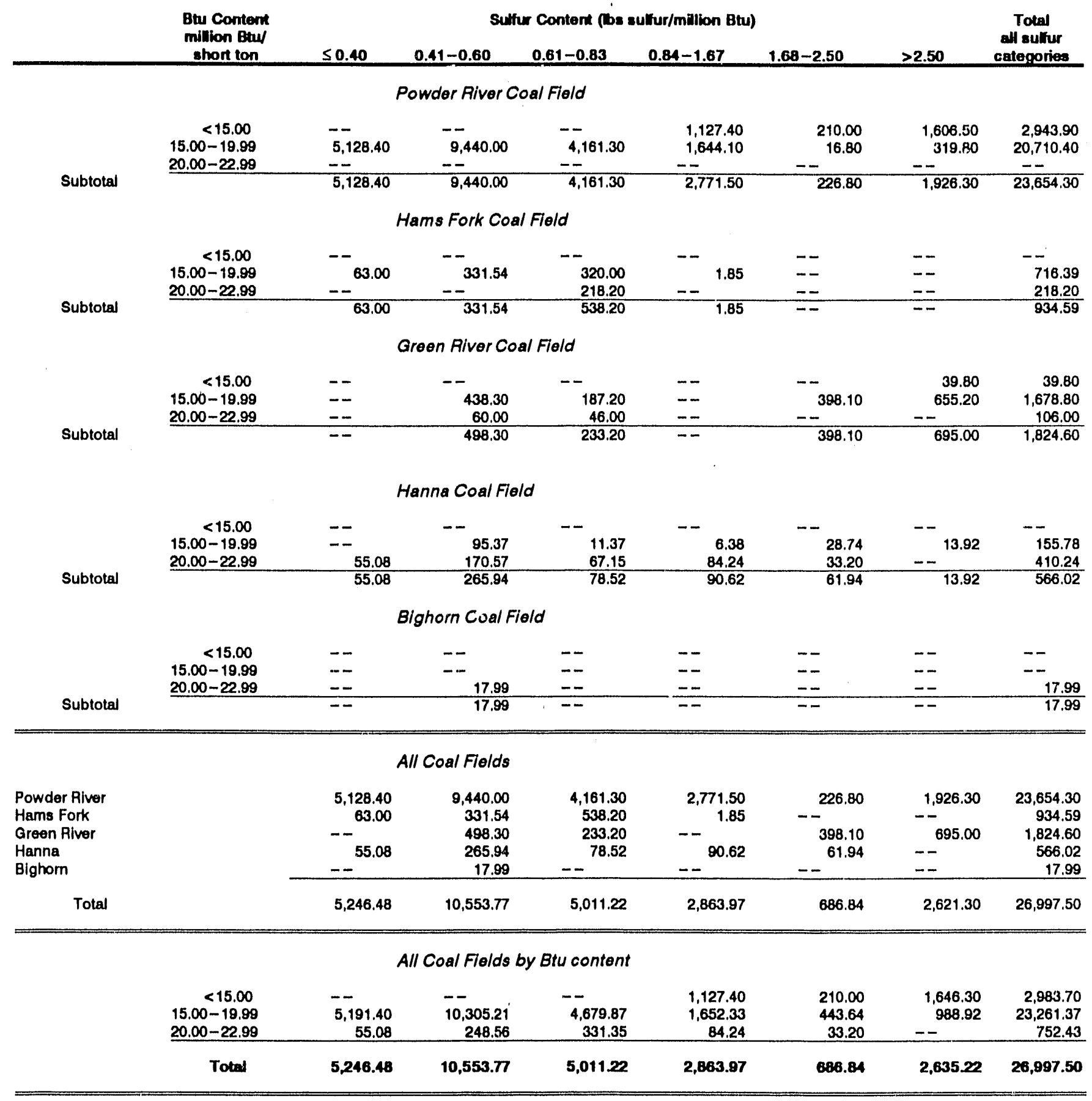


About 15.8 billion tons, or 58 percent, of Wyoming's strippable DRB occurs in EIA's two lowest sulfur categories. The GSW's estimate also places 2.6 billion tons, or 9.8 percent, of the strippable DRB coal into the highest sulfur category. While only about 3.0 billion short tons of Wyoming's strippable DRB occur in the lowest heating value category ( $<15.00$ million Btu/short ton), 86 percent or 23.3 billion tons occur in the 15.00 19.99 million Btu/short ton category. According to GSW's estimates, no strippable coal occurs in the highest heating value category, (23.00-25.99 million Btu/short ton).

The Powder River Coal Field contains about 23.7 billion short tons, or 87.6 percent, of Wyoming's total remaining strippable DRB. The Green River Coal Field contains about 1.8 billion short tons, or 6.8 percent, of the State's remaining strippable DRB; the Hams Fork Coal Field contains 935 million short tons, or 3.5 percent, of the strippable DRB; and the Hanna Coal Field contains 566 million short tons, or 2.1 percent, of the State's remaining strippable DRB.

The DRB, or estimated economic resources, of strippable coal in Wyoming is summarized in Table $3 \mathrm{~A}$ by rank of coal and ranges of Btu and sulfur content. In Table $3 \mathrm{~B}$ the state's minable reserve base of strippable coal comprises the portions of the DRB estimated to be free of land-use and regulatory restrictions, and therefore considered accessible for mining. The derivation of the minable reserve base estimates is discussed below.

In Table 3C the recoverable coal (or reserves) of strippable coal is summarized. These data represent the amount of coal in each rank and Btu or sulfur range that is expected to be recoverable from in-place deposits of the minable reserve base. The recoverable coal estimates were compiled by applying estimated recovery factors for individual coal deposits, as described below.

Tables 4A, 4B, and 4C contain estimates for underground coal resources and reserves in Wyoming. The distribution of these reserves by coal rank, Btu range, and sulfur range is primarily that used by the Energy Information Administration (1989); minor adjustments for recent underground coal production have veen incorporated into these estimates by the GSW. The GSW did not develop the underground reserve base data and has neither reviewed nor verified its accuracy or validity. In addition, the GSW has neither evaluated the inaccessible percentages for underground minable coals nor assessed the recovery factors for underground coal as used by the EIA for Wyoming coal 
Table 3.A. Summary of GSW's estimated economic resources of strippable coal in Wyoming, as of January 1, 1991 (in million short tons).

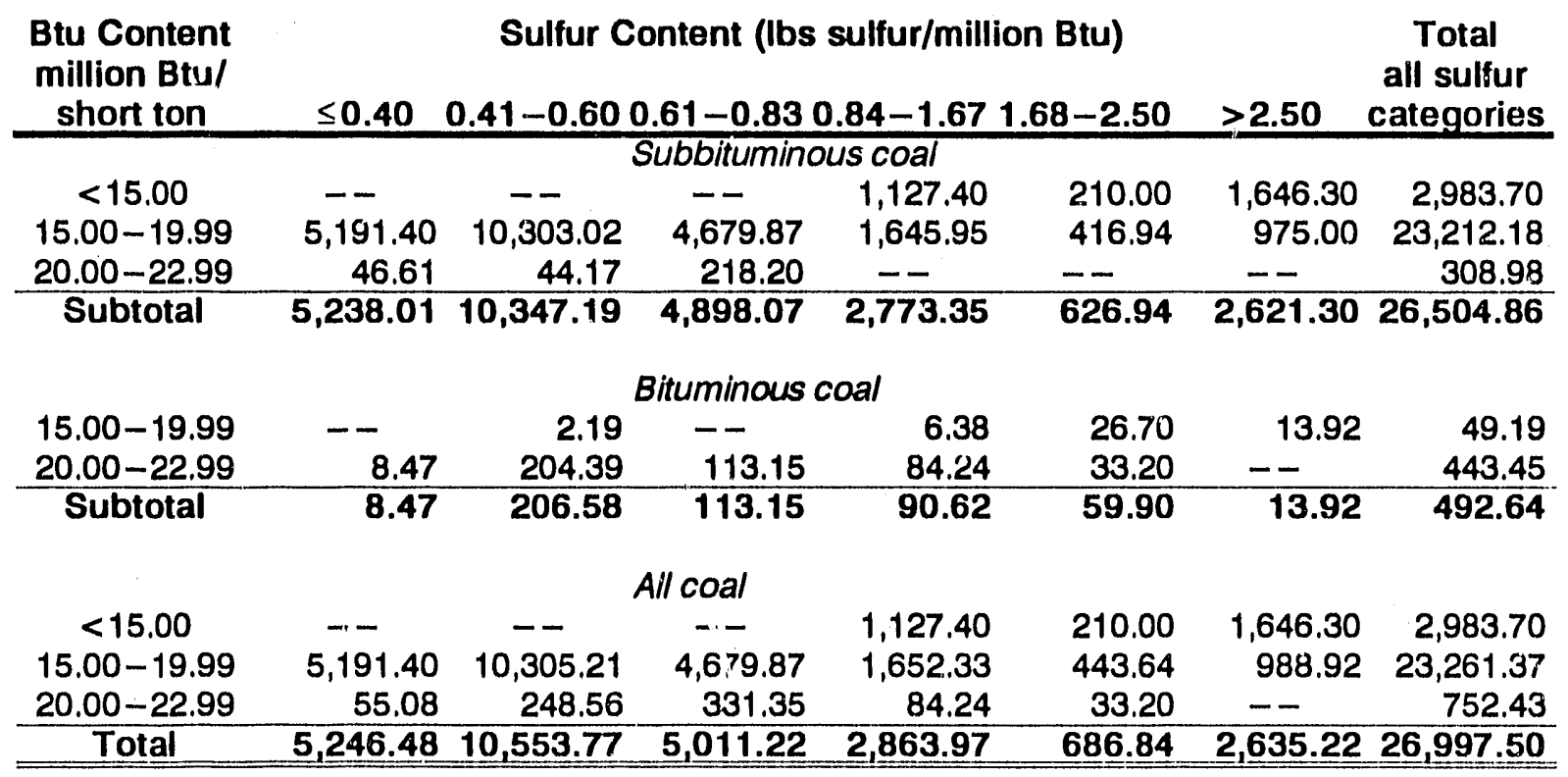

Table 3B. Summary of GSW's estimate of minable reserve base of strippable coal in Wyoming, as of January 1, 1991 (in million short tons).

\begin{tabular}{|c|c|c|c|c|c|c|c|}
\hline \multirow{2}{*}{$\begin{array}{l}\text { Btu Content } \\
\text { million Btu/ } \\
\text { short ton }\end{array}$} & \multicolumn{6}{|c|}{ Sulfur Content (Ibs sulfur/million Btu) } & \multirow{2}{*}{$\begin{array}{c}\text { Total } \\
\text { all sulfur } \\
\text { categories }\end{array}$} \\
\hline & $\leq \mathbf{0 . 4 0}$ & $0.41-0.60$ & $.61-0.83$ & $.84-1.67$ & $1.68-2.50$ & $>2.50$ & \\
\hline & & & \multicolumn{3}{|c|}{ subbituminous coal } & & \\
\hline$<15.00$ & -- & -- & -- & $1,018.40$ & 189.00 & $1,639.00$ & $2,846.40$ \\
\hline $15.00-19.99$ & $5,081.60$ & $10,077.01$ & $4,592.30$ & $1,603.95$ & 387.72 & 970.90 & $22,713.48$ \\
\hline $20.00-22.99$ & 46.14 & 43.73 & 217.55 & -- & -- & -- & 307.42 \\
\hline Subtotal & $5,127.74$ & $10,120.74$ & $4,809.85$ & $2,622.35$ & 576.72 & $2,609.30$ & $25,867.30$ \\
\hline \multicolumn{8}{|c|}{ Bituminous coal } \\
\hline $15.00-19.99$ & -- & 2.17 & -- & 6.32 & 26.63 & 13.92 & 49.04 \\
\hline 20.00 & 8.39 & 199 & 110.18 & 83.40 & 32.87 & -- & 434.78 \\
\hline Subtotal & 8.39 & 202.i1 & 110.18 & 89.72 & 59.50 & 13.92 & 483.82 \\
\hline \multicolumn{8}{|c|}{ All coal } \\
\hline$<15.00$ & -- & -- & -- & $1,018.40$ & 189.00 & $1,639.00$ & $2,846.40$ \\
\hline $15.00-19.9 s$ & $5,081,60$ & $10,079.18$ & $4,592.30$ & $1,610.27$ & 414.35 & 984.82 & $22,762.52$ \\
\hline $20.00-22.9$ & 54.53 & 243.67 & 327.73 & 83.40 & 32.87 & -- & 742.20 \\
\hline Total & $5,136.13$ & $10,322.85$ & $4,920.03$ & $2,712.07$ & 636.22 & $2,623.82$ & $26,351.12$ \\
\hline
\end{tabular}

Table 3C. Summary of GSW's estimate of recoverable strippable coal in Wyoming, as of January 1, 1991 (in million short tons).

\begin{tabular}{|c|c|c|c|c|c|c|c|}
\hline \multirow{2}{*}{$\begin{array}{c}\text { Btu Content } \\
\text { million Btu/ } \\
\text { short ton }\end{array}$} & \multicolumn{6}{|c|}{ Sulfur Content (Ibs sulfur/million Btu) } & \multirow{2}{*}{$\begin{array}{l}\text { Total } \\
\text { all sulfur } \\
\text { categories }\end{array}$} \\
\hline & $\leq 0.40$ & 04 & 0.61 & 84 & $68-2.50$ & $>2.50$ & \\
\hline & & & subbitumin & us coal & & & \\
\hline $\begin{array}{c}<15.00 \\
15.00-19.99 \\
20.00-22.99\end{array}$ & $\begin{array}{r}\overline{--} \\
4,555.60 \\
36.91\end{array}$ & $\begin{array}{r}-\overline{8,986.18} \\
34.98\end{array}$ & $\begin{array}{r}-\overline{-} \\
4,095.94 \\
174.04\end{array}$ & $\begin{array}{r}909.80 \\
1,402.28 \\
--\end{array}$ & $\begin{array}{l}170.10 \\
330.32 \\
--\end{array}$ & $\begin{array}{c}1,393.40 \\
831.10 \\
--\end{array}$ & $\begin{array}{r}2,473.30 \\
20,201.42 \\
245.93\end{array}$ \\
\hline Subtotal & $4,592.51$ & $9,021.16$ & $4,269.98$ & $2,312.08$ & 500.42 & $2,224.50$ & $22,920.65$ \\
\hline
\end{tabular}




\begin{tabular}{|c|c|c|c|c|c|c|c|}
\hline & & & coal & & & & \\
\hline 300 & $5, \overline{191.40}$ & $10,305,21$ & $4,-679.87$ & & & $\begin{array}{r}1,646.30 \\
988.92\end{array}$ & $\begin{array}{r}2,983.70 \\
23,261.37 \\
752\end{array}$ \\
\hline Total & $\begin{array}{r}55.08 \\
5.246 .48\end{array}$ & & $\begin{array}{r}331.35 \\
5.011 .22\end{array}$ & $\begin{array}{r}84.24 \\
2.863 .97\end{array}$ & & $\frac{--}{2.635 .22}$ & $\begin{array}{r}752.43 \\
26.997 .50\end{array}$ \\
\hline
\end{tabular}

Table 3B. Summary of GSW's estimate of minable reserve base of strippable coal in Wyoming, as of January 1, 1991 (in million short tons).

\begin{tabular}{|c|c|c|c|c|c|c|c|}
\hline \multirow{2}{*}{$\begin{array}{l}\text { Btu Content } \\
\text { million Btu/ } \\
\text { short ton }\end{array}$} & \multicolumn{6}{|c|}{ Sulfur Content (lbs sulfur/million Btu) } & \multirow{2}{*}{$\begin{array}{c}\text { Total } \\
\text { all sulfur } \\
\text { categories }\end{array}$} \\
\hline & $\leq 0.40$ & $0.41-0.60$ & $.61-0.83$ & $.84-1.67$ & $.68-2.50$ & $>2.50$ & \\
\hline & & & \multicolumn{3}{|c|}{ Subbituminous coal } & & \\
\hline$<15.00$ & -- & -- & -- & $1,018.40$ & 189.00 & $1,639.00$ & $2,846.40$ \\
\hline $15.00-19.99$ & $5,081.60$ & $10,077.01$ & $4,592.30$ & $1,603.95$ & 387.72 & 970.90 & 22,7 \\
\hline $20.00-22.99$ & 46.14 & 43.73 & 217.55 & -- & -- & -- & 307.42 \\
\hline Subtotal & $5,127.74$ & $10,120.74$ & $4,809.85$ & $2,622.35$ & 576.72 & $2,609.90$ & $25,867.30$ \\
\hline \multicolumn{8}{|c|}{ Bituminous coal } \\
\hline $15.00-19.99$ & -- & 2.17 & -- & 6.32 & 26.63 & 13.92 & 49.04 \\
\hline $20.00-22.99$ & 8.39 & 199.94 & 110.18 & 83.40 & 32.87 & -- & 434.78 \\
\hline Subtotal & 8.39 & 202.11 & 110.18 & 89.72 & 59.50 & 13.92 & 483.82 \\
\hline \multicolumn{8}{|c|}{ All coal } \\
\hline$<15.00$ & -- & -- & -- & $1,018.40$ & 189.00 & $1,639.00$ & $2,846.40$ \\
\hline $15.00-19.99$ & $5,081,60$ & $10,079.18$ & $4,592.30$ & $1,610.27$ & 414.35 & 984.82 & $22,762.52$ \\
\hline $20.00-22.99$ & 54.53 & 243.67 & 327.73 & 83.40 & 32.87 & -- & 742.20 \\
\hline Total & $5,136.13$ & $10,322.85$ & $4,920.03$ & $2, \overline{712.07}$ & 636.22 & $2,623.82$ & $26,351.12$ \\
\hline
\end{tabular}

Table 3C. Summary of GSW's estimate of recoverable strippable coal in Wyoming, as of January 1, 1991 (in million short tons).

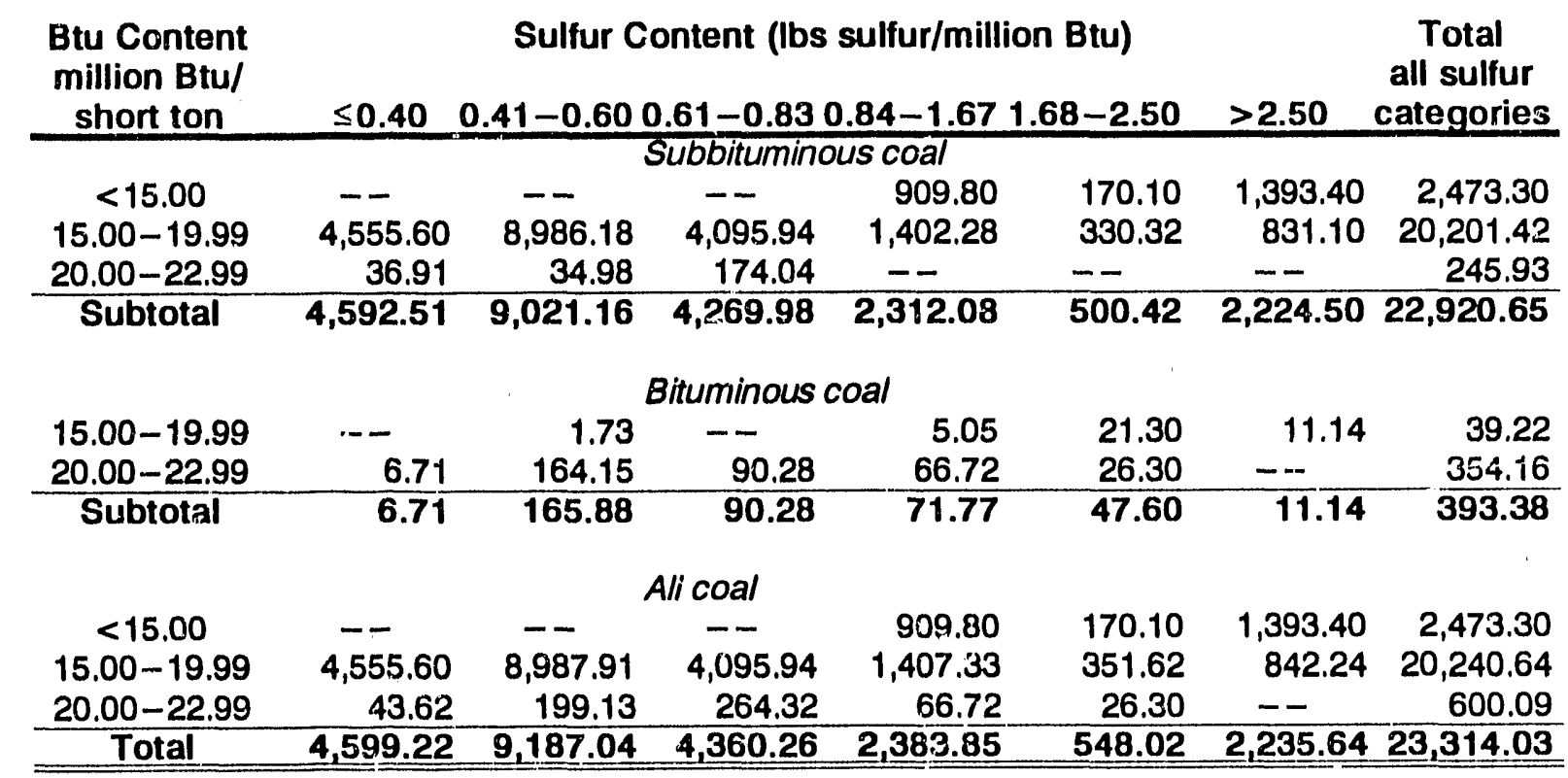


Table 4A. Summary of ElA's estimated economic resources of underground coal in Wyoming, as of January 1, 1991 (in million short tons).

\begin{tabular}{|c|c|c|c|c|c|c|c|}
\hline \multirow{2}{*}{$\begin{array}{l}\text { Btu Content } \\
\text { million Btu/ } \\
\text { short ton }\end{array}$} & \multicolumn{6}{|c|}{ Sulfur Content (Ibs sulfur/million Btu) } & \multirow{2}{*}{$\begin{array}{c}\text { Total } \\
\text { all sulfur } \\
\text { categories }\end{array}$} \\
\hline & $\leq 0.40$ & $0.41-0.60$ & $0.61-0.83$ & $.84-1.67$ & $.68-2.50$ & $>2.50$ & \\
\hline \multicolumn{8}{|c|}{ Sisbbituminous coal } \\
\hline 5.00 & $3,781,40$ & 15 & $9,691.90$ & $8,780.70$ & $1,186.10$ & -- & 38,6 \\
\hline Subt & $3,781.40$ & 15,2 & $9,691.90$ & $8,780.70$ & 1,1 & 0.00 & 38 \\
\hline \multicolumn{8}{|c|}{ Bituminous coal } \\
\hline 20.00 & 493.70 & 504 & 687.40 & 36 & -- & 61.10 & .00 \\
\hline 23.00 & 82.70 & & & & -- & -- & 7.60 \\
\hline Subtc & 576.40 & $1,011.50$ & $1,522.40$ & 71 & 0.00 & 61.10 & $3,881.60$ \\
\hline \multicolumn{8}{|c|}{ All coal } \\
\hline $15.00-19.99$ & $3,781,40$ & $15,223.00$ & $9,691 . S$ & $8,780.70$ & $1,186.10$ & -- & $38,663.10$ \\
\hline $20.00-22.99$ & 493.70 & 504.70 & 687.40 & & -- & 61.10 & $2,114.00$ \\
\hline $23.00-25.99$ & 82.70 & 506.80 & 835.00 & 343.10 & $-\cdots$ & -- & $1,767.60$ \\
\hline Total & $4,357.80$ & $16,234.50$ & $11,214.30$ & $9,490.90$ & $1,186.10$ & 61.10 & $42,544.70$ \\
\hline
\end{tabular}

Table 4B. Summary of EIA's estimate of minable reserve base of underground coal in Wyoming, as of January 1, 1991 (in million short tons).

\begin{tabular}{|c|c|c|c|c|c|c|c|}
\hline \multirow{2}{*}{$\begin{array}{l}\text { Btu Content } \\
\text { million Btu/ } \\
\text { short ton }\end{array}$} & \multicolumn{6}{|c|}{ Sulfur Content (Ibs sulfur/million Btu) } & \multirow{2}{*}{$\begin{array}{c}\text { Total } \\
\text { all sulfur } \\
\text { categories }\end{array}$} \\
\hline & $\leq 0.40$ & $0.41-0.60$ & $0.61-0.83$ & $.84-1.67$ & $.68-2.50$ & 2.50 & \\
\hline \multicolumn{8}{|c|}{ Subbituminous coal } \\
\hline $15.00-19.99$ & $3,403.26$ & $13,700.70$ & $8,722.71$ & $7,902.63$ & $1,067.49$ & -- & $34,796.79$ \\
\hline Subtotal & $3,403.26$ & $13,700.70$ & $8,722.71$ & 7,90 & $1,067.49$ & 0.00 & $\mathbf{3 4 , 7}$ \\
\hline \multicolumn{8}{|c|}{ Bituminous coal } \\
\hline $20.00-22.99$ & 444.33 & 454.23 & 618.66 & 330.39 & -- & 54.99 & $1,902.50$ \\
\hline $23.00-$ & 74.43 & & & 9 & -- & -- & .84 \\
\hline Subtotal & 518.76 & 910.35 & $1,370.16$ & 18 & 0.00 & 54.99 & $3,493.44$ \\
\hline \multicolumn{8}{|c|}{ All coal } \\
\hline $15.00-19.99$ & $3,403.26$ & $13,700.70$ & $8,722.7$ & $7,902.63$ & $1,067.49$ & -- & $34,796.79$ \\
\hline $20.00-22.99$ & 444.33 & 454.23 & 618.6 & & -- & 54.99 & $1,902.60$ \\
\hline 23.00 & 74.43 & 456.12 & 751.50 & 308.79 & -- & -- & $1,590.84$ \\
\hline Total & $3,922.02$ & $14,611.05$ & $0,092.87$ & $8,541.81$ & $1,067.49$ & 54.99 & 0.23 \\
\hline
\end{tabular}

Table 4C. Summary of EIA's estimate of recoverable underground coal in Wyoming, as of January 1, 1991 (in million short tons).

\begin{tabular}{|c|c|c|c|c|c|c|c|}
\hline \multirow{2}{*}{$\begin{array}{l}\text { Btu Content } \\
\text { million Btu/ } \\
\text { short ton }\end{array}$} & \multicolumn{6}{|c|}{ Sulfur Content (Ibs sulfur/million Btu) } & \multirow{2}{*}{$\begin{array}{c}\text { Total } \\
\text { all sulfur } \\
\text { categories }\end{array}$} \\
\hline & $\leq 0.40$ & $0.41-0.60$ & $0.61-0.83$ & $0.84-1.67$ & $1.68-2.50$ & $>2.50$ & \\
\hline \multicolumn{8}{|c|}{ Subbituminous coal } \\
\hline $15.00-19.99$ & $2,041.96$ & $8,220.42$ & $5,233.63$ & $4,741.58$ & 640.49 & -- & 3.08 \\
\hline Subtotal & $2,041.96$ & $8,220.42$ & $5,233.63$ & $4,741.58$ & 640.49 & 0. & $20,878.08$ \\
\hline
\end{tabular}


Btu Content Subbituminous coal

\begin{tabular}{|c|c|c|c|c|c|c|c|}
\hline \multicolumn{8}{|c|}{ Subbituminous coal } \\
\hline $5.00-1$ & $3,403.26$ & $13,700.70$ & $8,722.71$ & $7,902.63$ & $1,067.49$ & - & $34,796.79$ \\
\hline Subtotal & $3,403.26$ & $13,700.70$ & $8,722.71$ & $7,902.63$ & $1,067.49$ & 0.00 & $34,796.79$ \\
\hline \multicolumn{8}{|c|}{ Bituminous coal } \\
\hline $20.00-22.99$ & 444.33 & 454.23 & 618.66 & 330.39 & -- & 54.99 & $1,902.6$ \\
\hline $23.00-25.99$ & 74.43 & 456.12 & 751.50 & 308.79 & -- & -- & $1,590.8$ \\
\hline Subtotal & 518.76 & 910.35 & $1,370.16$ & 639.18 & 0.00 & 54.99 & $3,493.4$ \\
\hline
\end{tabular}

\begin{tabular}{crrrrrrr} 
& \multicolumn{1}{c}{ All coal } \\
$15.00-19.99$ & $3,403.26$ & $13,700.70$ & $8,722.71$ & $7,902.63$ & $1,067.49$ & - & $34,796.79$ \\
$20.00-22.99$ & 444.33 & 454.23 & 618.66 & 330.39 & -- & 54.99 & $1,902.60$ \\
$23.00-25.99$ & 74.43 & 456.12 & 751.50 & 308.79 & -- & -- & $1,590.84$ \\
\hline Total & $\mathbf{3 , 9 2 2 . 0 2}$ & $\mathbf{1 4 , 6 1 1 . 0 5}$ & $\mathbf{1 0 , 0 9 2 . 8 7}$ & $\mathbf{8 , 5 4 1 . 8 1}$ & $\mathbf{1 , 0 6 7 . 4 9}$ & $\mathbf{5 4 . 9 9}$ & $\mathbf{3 8 , 2 9 0 . 2 3}$
\end{tabular}

Table 4C. Summary of EIA's estimate of recoverable underground coal in Wyoming, as of January 1, 1991 (in million short tons).

\begin{tabular}{|c|c|c|c|c|c|c|c|}
\hline \multirow{3}{*}{$\begin{array}{c}\text { Btu Content } \\
\text { million Btu/ } \\
\text { short ton } \\
\end{array}$} & \multicolumn{6}{|c|}{ Sulfur Content (Ibs sulfur/million Btu) } & \multirow{2}{*}{$\begin{array}{c}\text { Total } \\
\text { all sulfur } \\
\text { categories }\end{array}$} \\
\hline & $\leq 0.40$ & $0.41-0.60$ & $0.61-0.83$ & $.84-1.67$ & $1.68-2.50$ & $>2.50$ & \\
\hline & \multicolumn{7}{|c|}{ Subbituminous coal } \\
\hline 15.00 & $2,041.96$ & .42 & $5,233.63$ & $4,741.58$ & 64 & -- & $20,878.08$ \\
\hline Subtotal & $2,041.96$ & $8,220.42$ & $5,233.63$ & 1.58 & .49 & 0.00 & 20,8 \\
\hline \multicolumn{8}{|c|}{ Bituminous coal } \\
\hline $20.00-22.99$ & 266.60 & 272.54 & 371.20 & 198 & -- & 32.99 & $1,141.56$ \\
\hline $23.00-25.99$ & 44.65 & 273.67 & & & -- & -- & 954.49 \\
\hline Subtotal & 311.25 & 546.21 & 822.10 & 383.50 & 0.00 & 32.99 & $2,096.05$ \\
\hline \multicolumn{8}{|c|}{ All coal } \\
\hline $15.00-19.99$ & $2,041.96$ & $8,220.42$ & $5,233.63$ & $4,741.58$ & 640.49 & -- & $20,878.08$ \\
\hline $20.00-22.99$ & 266.60 & 272.54 & 371.20 & 198.23 & -- & 32.99 & $1,141.56$ \\
\hline $23.00-25.9$ & 44.65 & 273.67 & 450. & 185.27 & -- & -- & 954.49 \\
\hline Total & $2,353.21$ & $8,766.63$ & $6,055.73$ & $5,125.08$ & 640.49 & 32.99 & $22,974.13$ \\
\hline
\end{tabular}


deposits. Those areas of information were beyond the scope of study of this project, but are included to permit a statewide summary of the data currently available.

Table 5 contains a detailed assessment of estimated economic resources, minable reserve base, and recoverable coal reserves for strippable coal. To calculate minable reserve base, the inaccessible percentages for land usage and for environmental restrictions were first determined separately, using map measurements, field observations, and published land use plans for individual coal deposits. Once this was done, the remaining reserves were aggregated and averaged in Table 5 according to coal rank, Btu range, and sulfur range. Similarly, recovery factors (for calculated recoverable coal) were first determined for individual coal deposits, based on published and unpublished data and GSW's best estimates, and then aggregated and averaged in Table 5.

The inaccessible percentages and recovery factors for strippable coal reported in Table 5 are averages derived from aggregating the various resources and reserves for all sulfur ranges within a standard Btu range. The average inaccessible percentage or recovery factor as reported in Table 5 cannot be used to derive individual minable reserve base or recoverable coal for a particular Btu and sulfur range.

Table 5 also contains estimates for underground coal reserves in Wyoming. Inaccessible underground coal due to land usage and environmental restrictions was calculated using factors developed by EIA; recovery factors for underground coal are also those used by EIA. The GSW can neither agree nor disagree with the accuracy or validity of these factors.

The last two pages of Table 5 summarize all Wyoming coal resources and reserves by ranges of Btu content and by ranges of sulfur content. These two pages contain statewide totals for all categories of coal reserves as well as final totals for estimated economic resources, minable reserve base, and recoverable coal reserves.

4.2 Regional Results by Strippable Coal Deposit. The individual reports on coal fields and deposits in Appendices A through $\mathrm{F}$ form the basis for the GSW revisions to the remaining strippable DRB for Wyoming. 


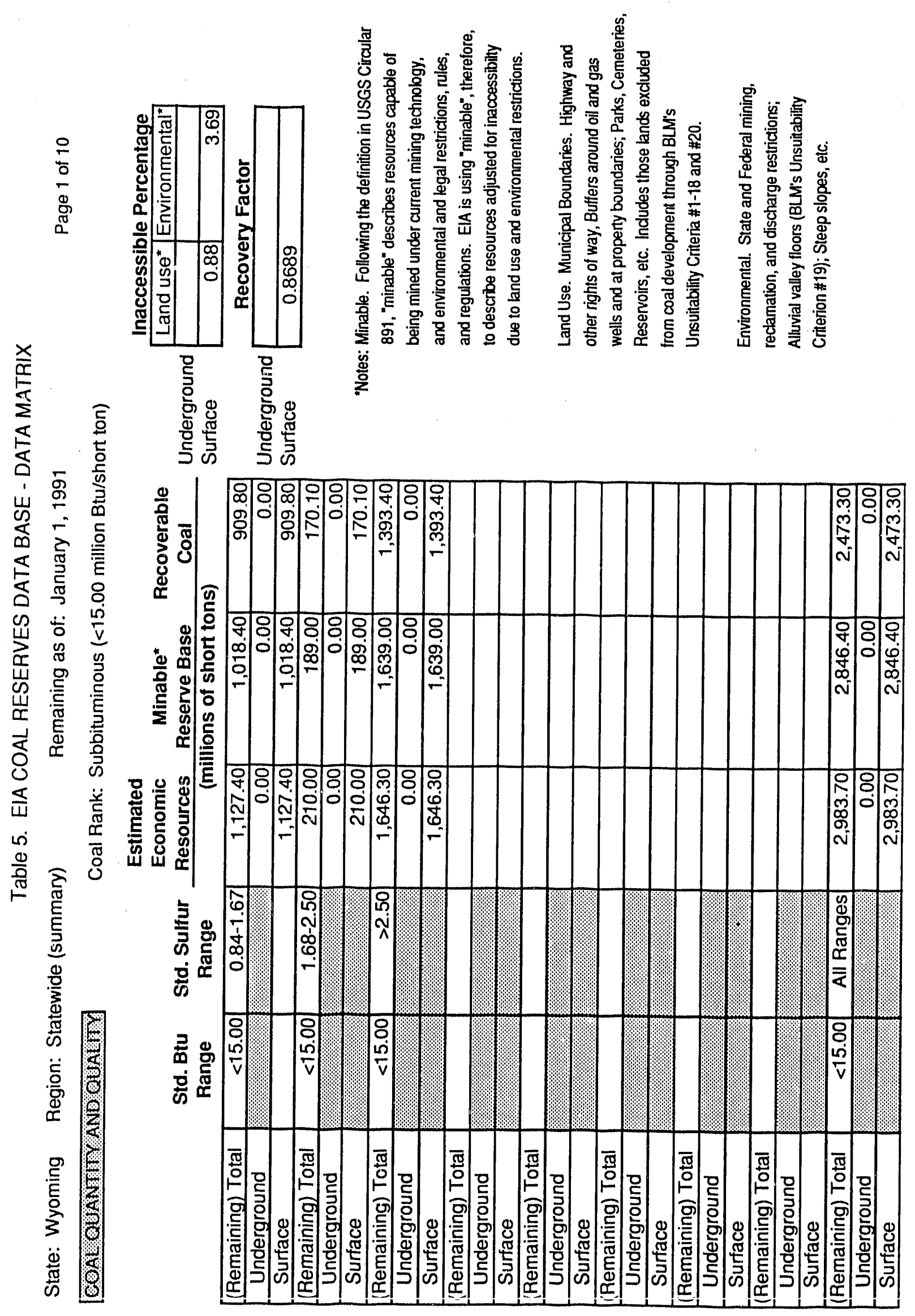




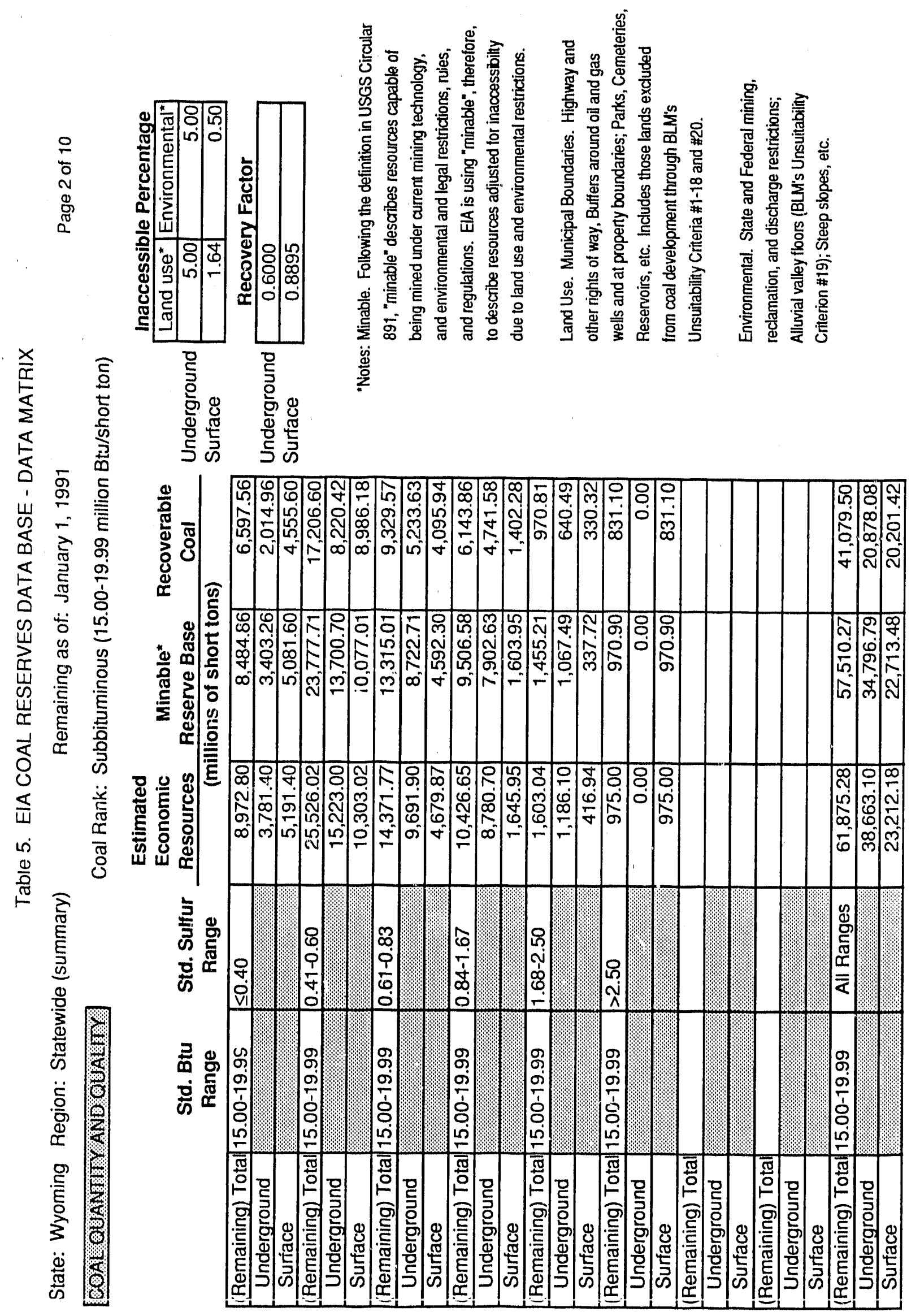




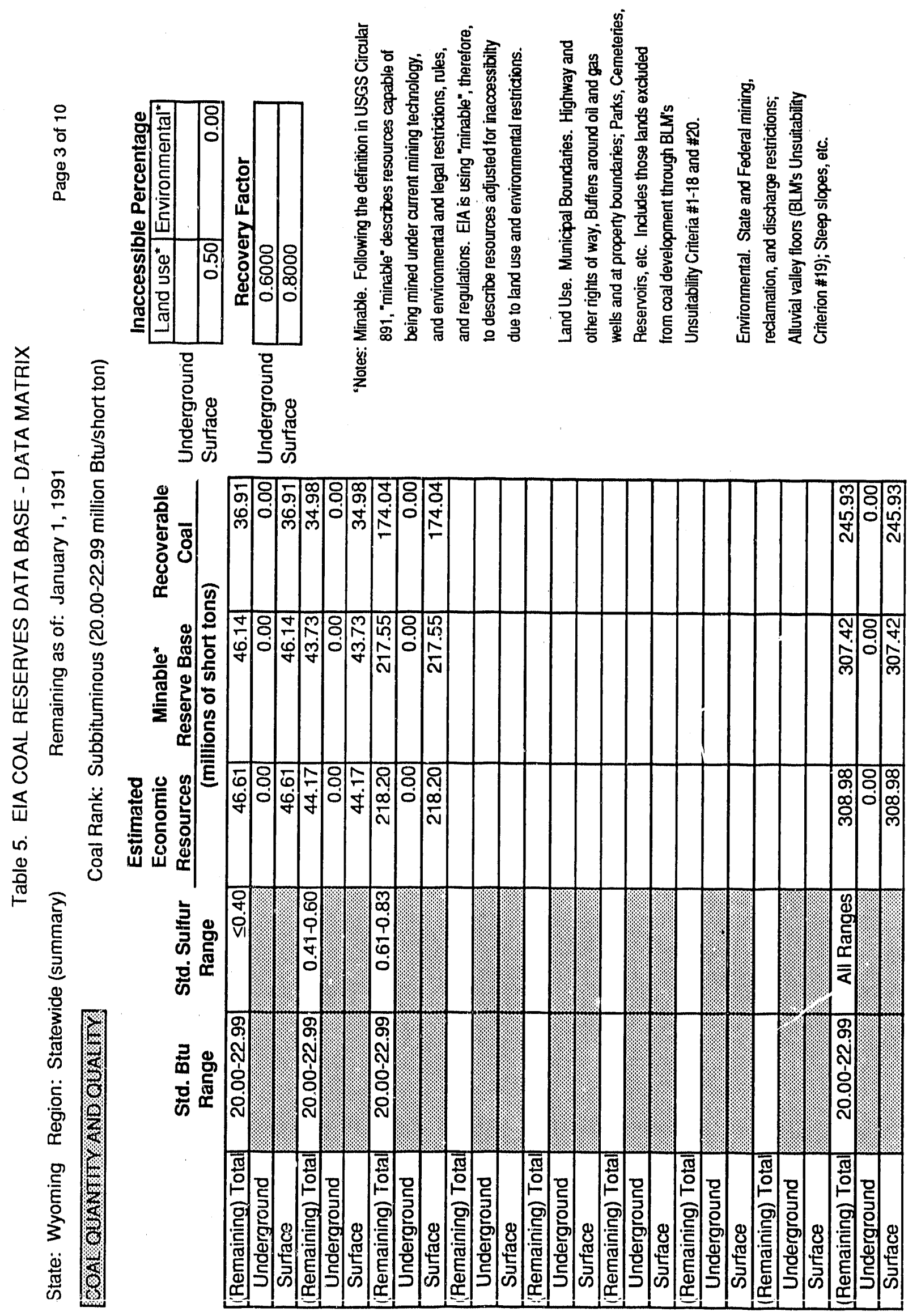




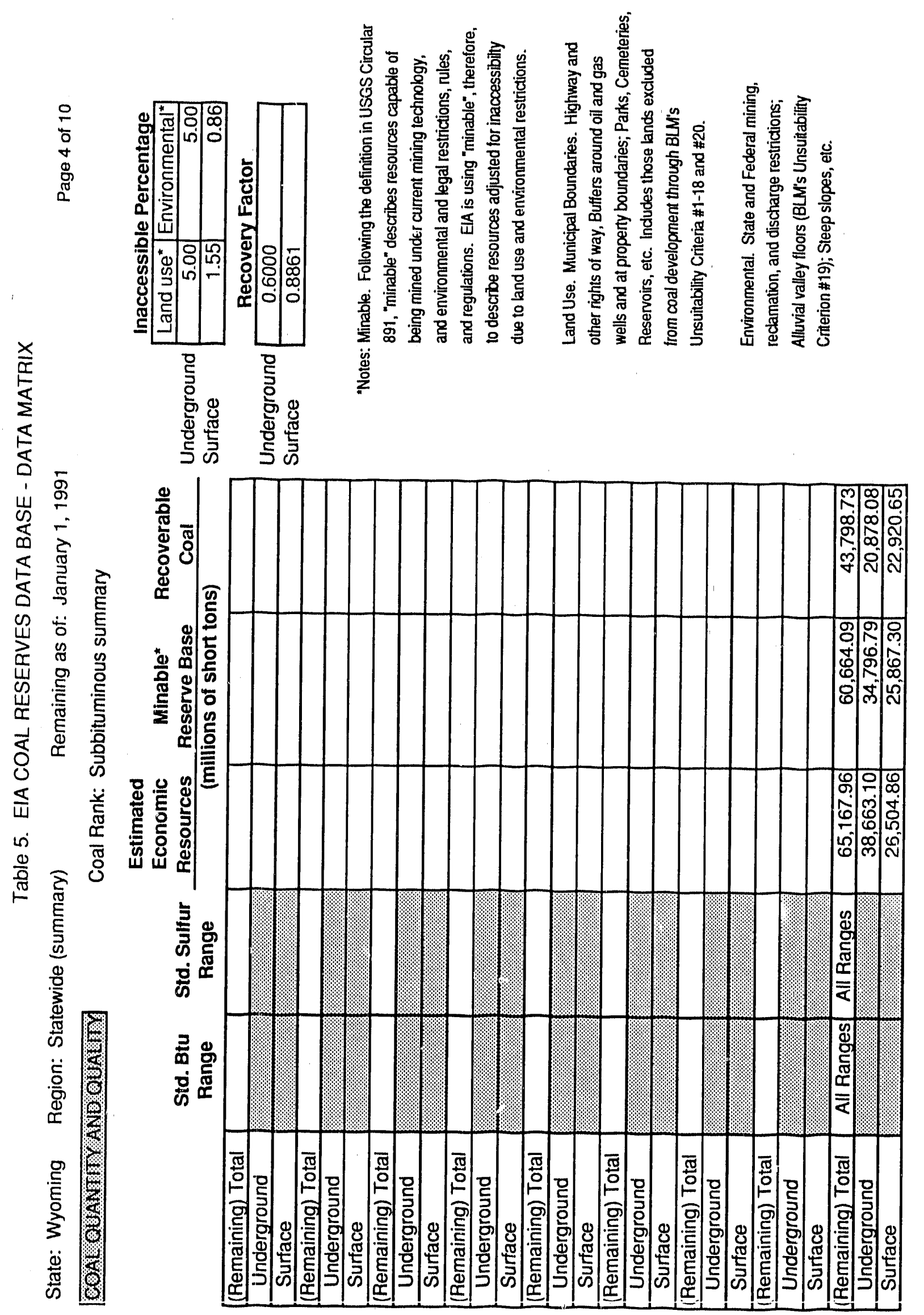




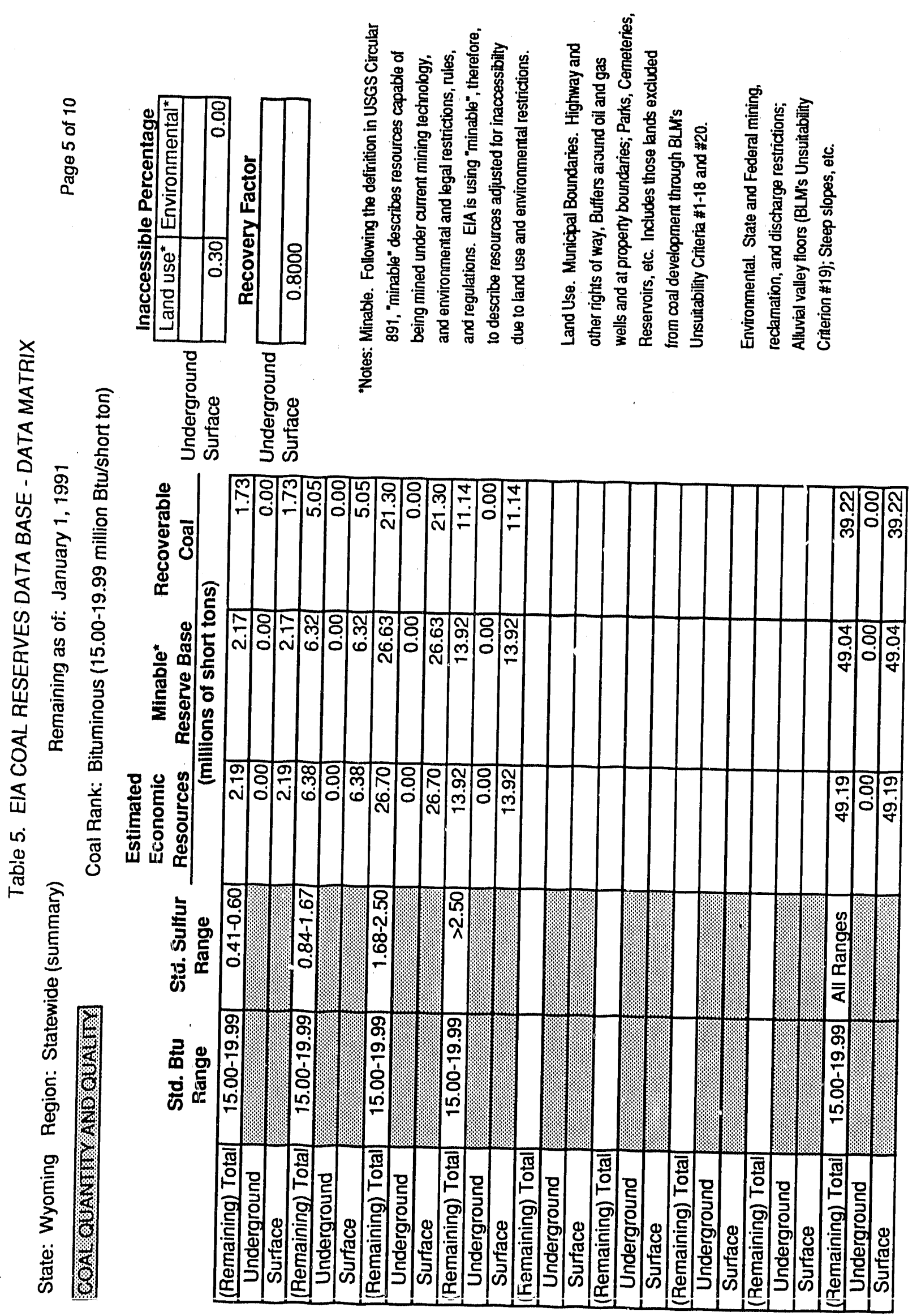




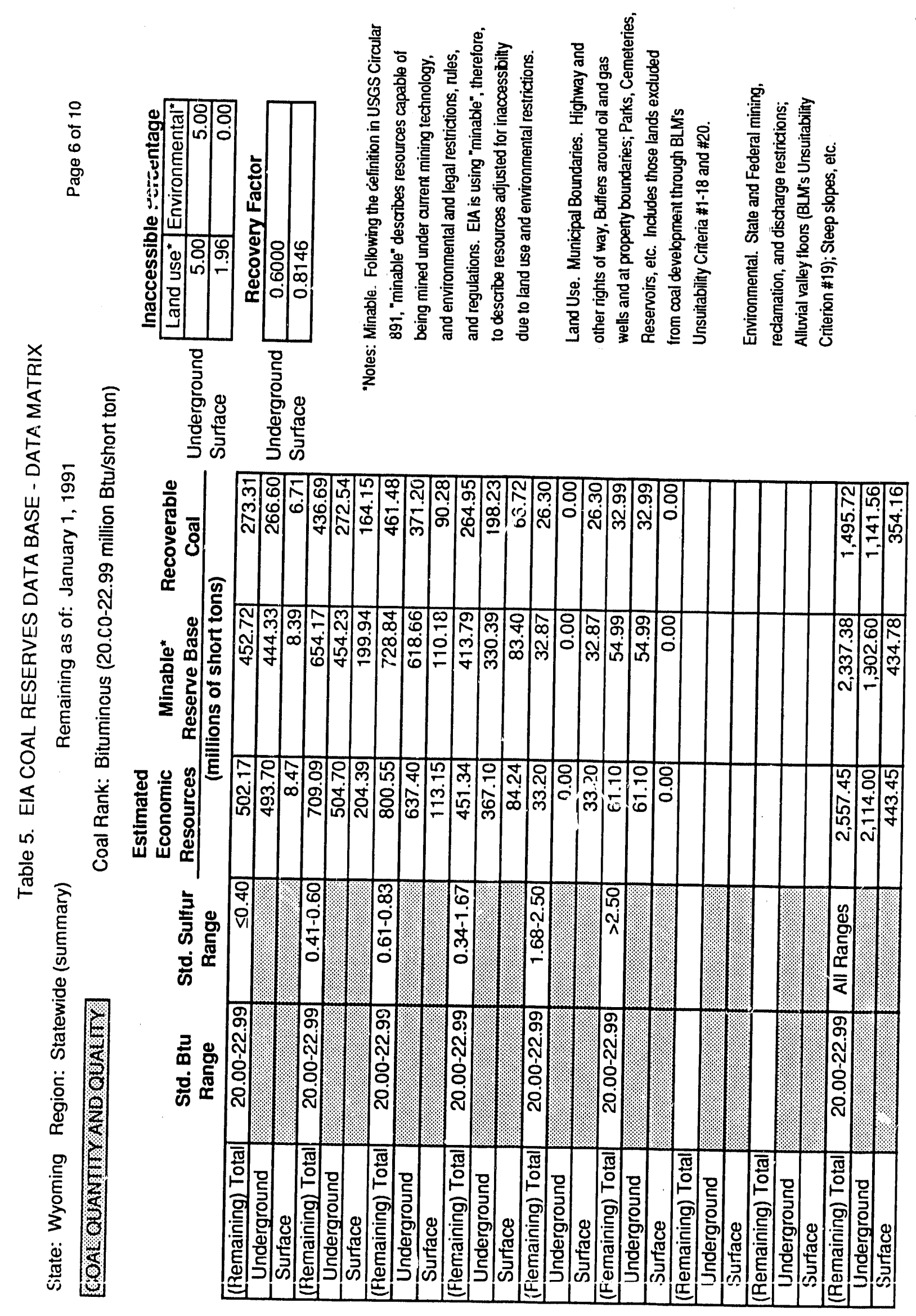




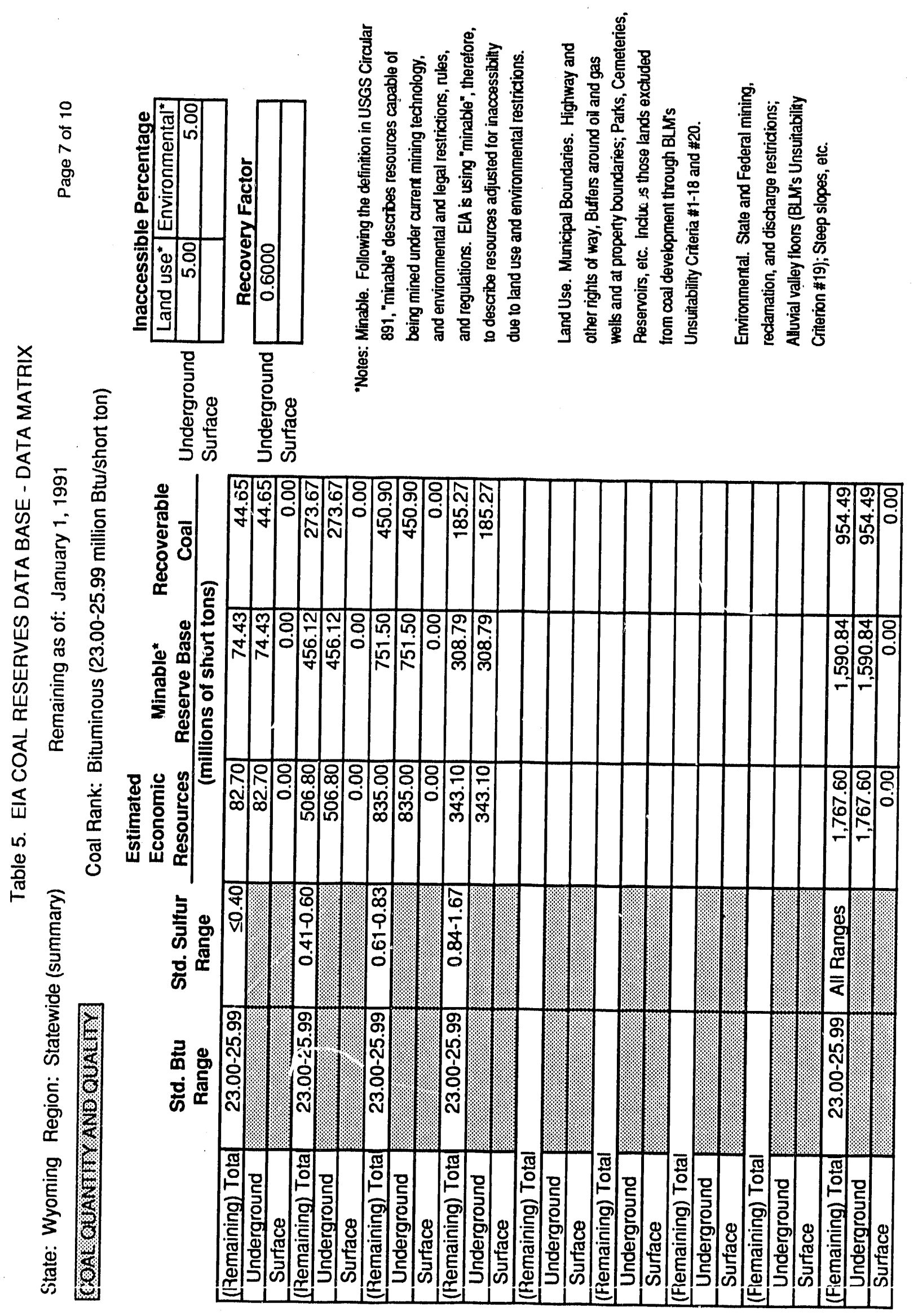




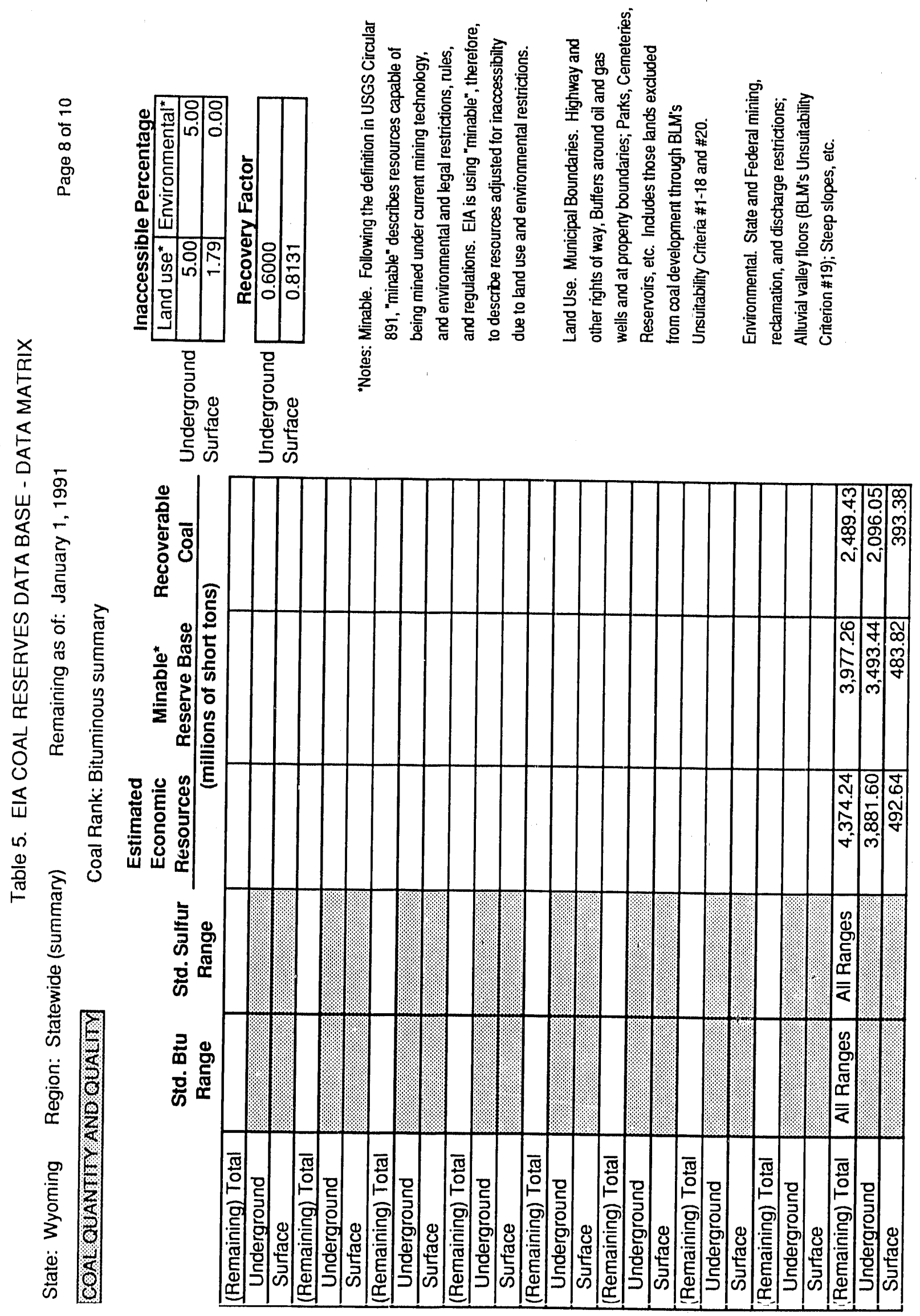




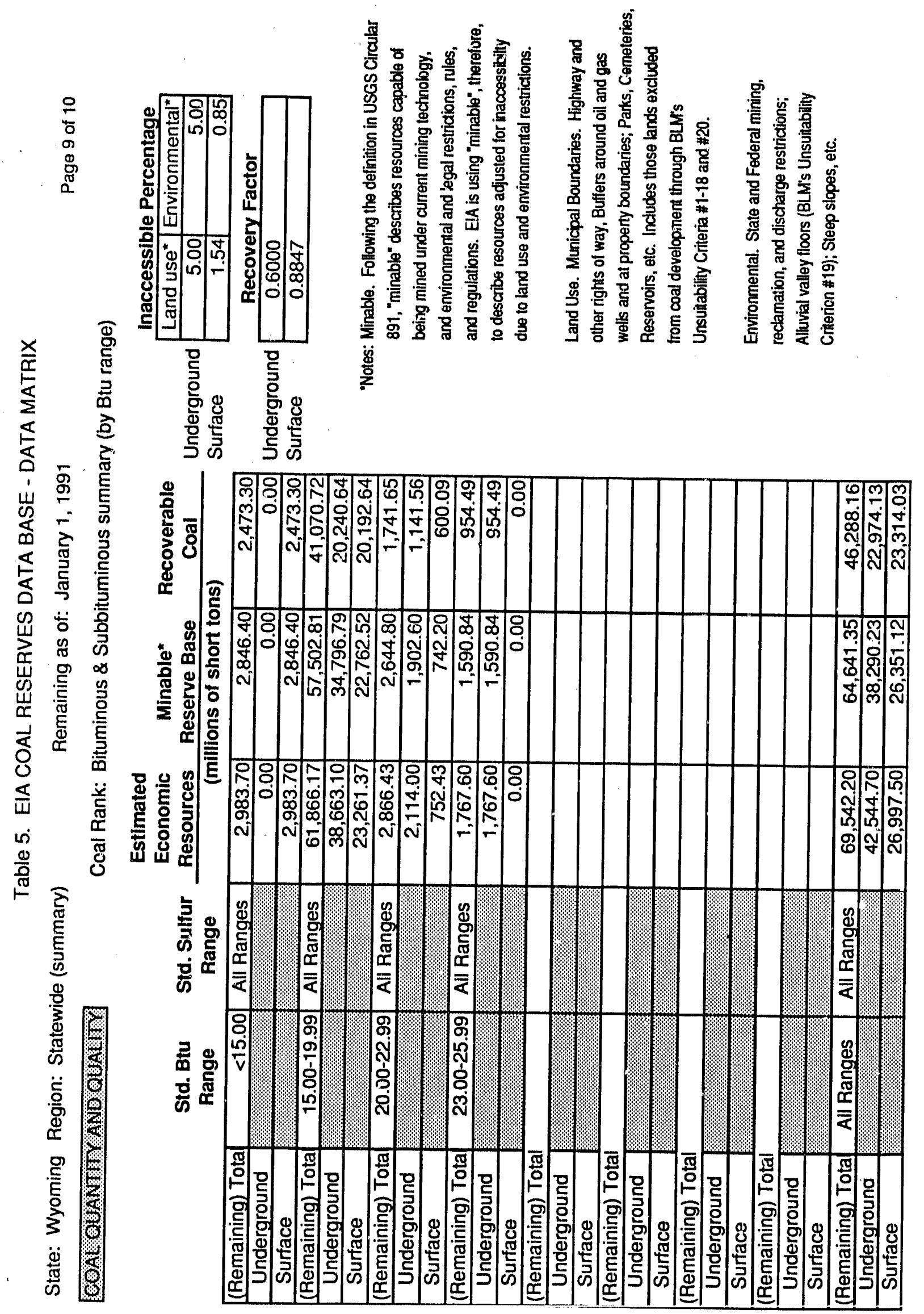




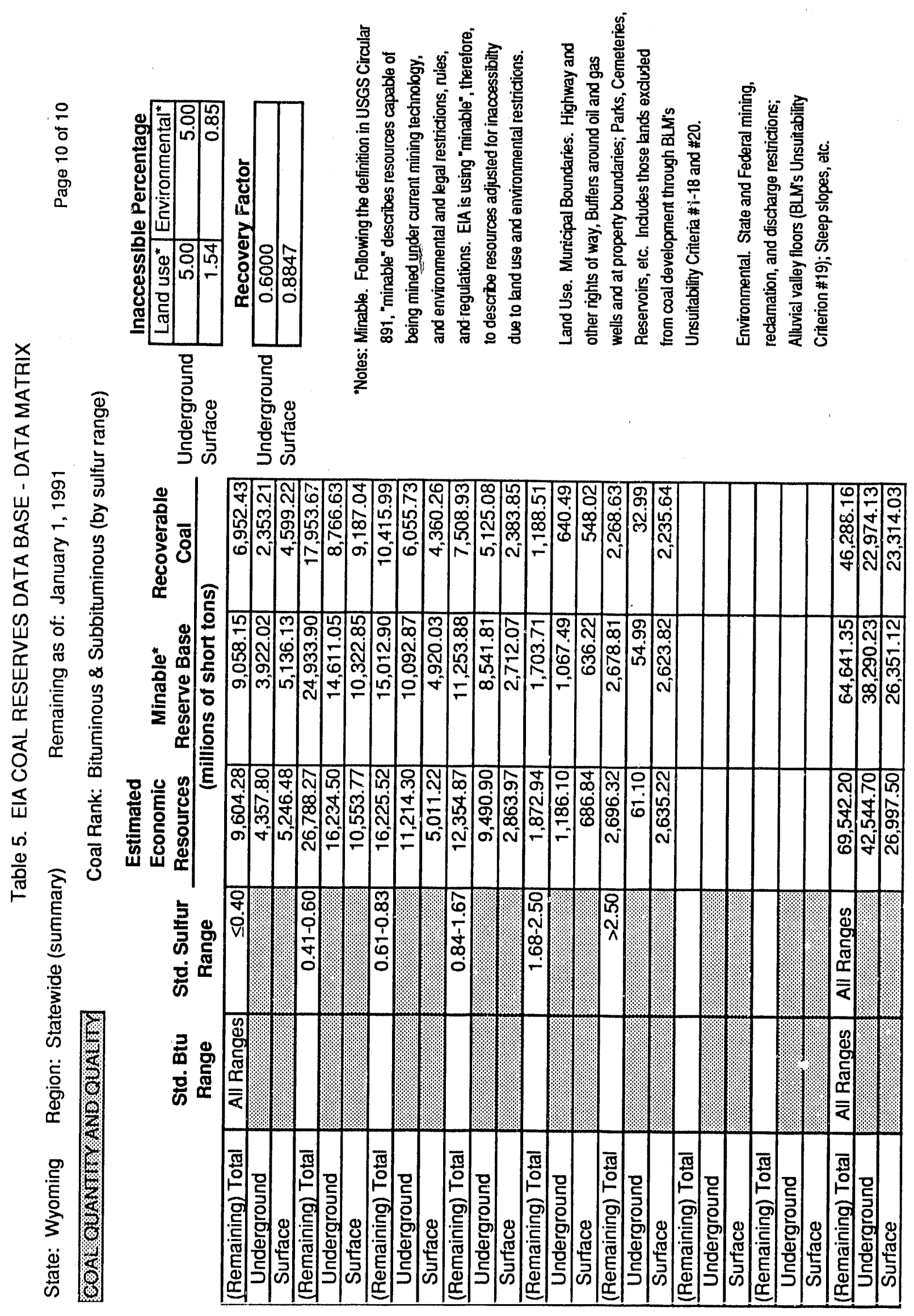




\subsection{SOURCES}

Many of the sources of data used to estimate the original demonstrated reserve base (DRB) tonnages for strippable coal deposits in Wyoming are no longer accurate, reliable, or adequate. Recent geologic and coal resource mapping, as well as numerous coal analyses and drill holes must all be incorporated into any new reserve base estimates. Detailed coal deposit maps that did not exist at the time many of the original DRB reports were written can now be constructed and used to redefine and recalculate the DRB. This Phase I project could only incorporate the recent coal quality data into the reserve base. A Phase II project would allow this new coal quality data to be matched with new tonnage estimates to redefine both the strippable and underground DRB.

This report used coal analyses from at least 5,230 channel, tipple, and core samples and over 1,500 delivered samples. Those data are derived from a variety of different sources which are shown on the tables of analytical data presented in the reports on individual coal deposits. Other references used to compile this report are listed below.

\subsection{List of References}

Black Butte Coal Company, 1976, Surface mine permit application and mine plan, Volume 1: submitted to the State of Wyoming, Department of Environmental Quality and the U.S. Geological Survey, Conservation Division.

Culbertson, W.C., and Mapel, W.J., 1976, Coal in the Wasatch Formation, northwest part of the Powder River Basin, near Sheridan, Sheridan County, Wyoming: Wyoming Geological Association 28th Annual Field Conference Guidebook, p. 193201.

Cumberland Coal Company, 1977, Mining plan for proposed South Haystack mine, Permit No. TFN1 6/294: submitted to State of Wyoming, Department of Environmental Quality, 6 volumes.

Energy Information Administration, 1989, Estimation of U.S. coal reserves by coal type - heat and sulfur content: Department of Energy, Energy Information Administration DOE/EIA-0529, $57 \mathrm{p}$. 
Glass, G.B., 1976, Update on the Powder River coal basin: Wyoming Geological Association 28th Annual Field Conference Guidebook, p. 289-220.

Glass, G.B., 1981, Coal deposits of Wyoming: Wyoming Geological Association 32nd Annual Field Conference Guidebook, p. 181-236.

Glass, G.B., 1983, Coal deposits of Wyoming, in Keystone Coal Industry Manual: McGraw-Hill, New York, p. 651-676.

Glass, G.B., 1985, Coal deposits of Wyoming, in Keystone Coal Industry Manual: McGraw-Hill, New York, p. 610-636.

Glass, G.B., and Jones, R.W., 1991, Coal fields and coal beds of Wyoming: Wyoming Geological Association 42nd Field Conference Guidebook, p. 133-167.

Glass, G.B., and Roberts, J.T., 1979, Remaining strippable coal resources and strippable reserve base of the Hanna Coal Field in southcentral Wyoming: Geological Survey of Wyoming Report of Investigations 17, $166 \mathrm{p}$.

Glass, G.B., Westervelt, K., and Oviatt, C.G., 1975, Coal mining in the Bighorn Coal Basin of Wyoming: Wyoming Geological Association 27th Annual Field Conference Guidebook, p. 221-228.

Grazis, S.L., 1977, Geologic map and coal resources of the Scaper Reservoir Quadrangle, Campbell County, Wyoming: U.S. Geological Survey Coal Investigations Map C-77, scale $1: 24,000,3$ sheets.

Haddock, D.R., Kent, B.H., and Bohor, B.F., 1976, Geologic map and coal sections of the Croton Quadrangle, Campbell County, Wyoming: U.S. Geological Survey Miscellaneous Field Studies Map MF-826, scale 1:24,000.

Honey, J.G., and Hettinger, R.D., 1989, Stratigraphic sections showing coal correlations within the lower coal zone of the Paleocene Fort Union Formation, Fillmore Ranch and Seaverson Reservoir Quadrangles, Carbon County, Wyoming: U.S. Geological Survey Coal Investigations Map C-127. 
Kent, B.H., Haddock, D.R., and Bohor, B.F., 1977, Geologic map and coal sections of the Truman Draw Quadrangle, Campbell County, Wyoming: U.S. Geological Survey Miscellaneous Field Studies Map MF-917, scale 1:24,000.

Mapel, W.J., 1959, Geology and coal resources of the Buffalo-Lake DeSmet area, Johnson and Sheridan Counties, Wyoming: U.S. Geological Survey Bulletin 1078, $148 \mathrm{p}$.

Masursky, Harold, 1962, Uranium-bearing coal in the eastern part of the Red Desert area, Wyoming: U.S. Geological Survey Bulletin 1099-B, p. B1-B52.

Northern Energy Resources Company, 1977a, [Coal] Exploration license application, Cherokee coal field: submitted to Wyoming Department of Environmental Quality, Figure 8, p. 21.

Northern Energy Resources Company, 1977b, Update and amendment of Mining Permit No. 338C: submitted to State of Wyoming, Department of Environmental Quality for Jim Bridger mine, Sweetwater County, Wyoming, Figure 17.

Pipiringos, G.N., 1961, Uranium-bearing coal in the central part of the Great Divide Basin; U.S. Geological Survey Bulletin 1099-A, 104 p.

Rocky Mountain Energy Company, 1976, Coal development program, southwestern Wyoming: Rocky Mountain Energy Company informational publication, $39 \mathrm{p}$.

Rocky Mountain Energy Company, 1981, Project activity update, March, 1981: Rocky Mountain Energy Company informational publication, $32 \mathrm{p}$.

Rocky Mountain Energy Company, 1982, Project activity update, July, 1982: Rocky Mountain Energy Company informational publication, 45 p.

Roehler, H.W., 1974, Geologic map of the Burley Draw Quadrangle, Sweetwater County, Wyoming: U.S. Geological Survey Geologic Quadrangle Map GQ-1200, scale 1:24,000.

Roehler, H.W., 1979a, Geologic map of the Camel Rock Quadrangle, Sweetwater

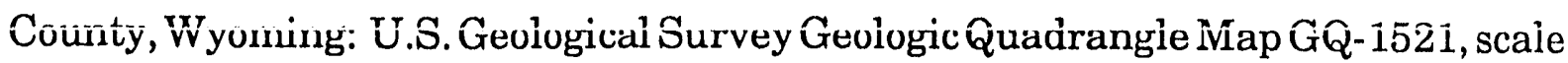
$1: 24,000$. 
Roehler, H.W., 1979b, Geology of the Cooper Ridge NE Quadrangle, Sweetwater County, Wyoming: U.S. Geological Survey Professional Paper 1065-B, 45 p.

Roehler, H.W., 1979c, Geology and mineral resources of the Mud Springs Ranch Quadrangle, Sweetwater County, Wyoming: U.S. Geological Survey Professional Paper 1065-C, $35 \mathrm{p}$.

Smith, J.B., Ayler, M.F., Knox, C.C., and Pollard, B.C., 1972, Strippable coal reserves of Wyoming: U.S. Bureau of Mines Information Circular 8538, 51 p.

U.S. Geological Survey, 1974, Minutes of the Mineral Land Evaluation Committee, Grass Creek Known Coal Leasing Area, Hot Springs County, Wyoming: Wyoming Coal Land Leasing Minutes, No. 5, 6 p.

Warwick, P.D., 1985, Depositional environments and petrology of the Felix coal interval (Eocene), Powder River Basin, Wyoming: Ph.D. Dissertation, University of Kentucky, $349 \mathrm{p}$.

Wood, G.H., Jr., Kehn, T.M., Carter, M.D., and Culbertson, W.C., 1983, Coal resource classification system of the U.S. Geological Survey: U.S. Geological Survey Circular $891,65 \mathrm{p}$.

Wyoming Department of Environmental Quality and U.S. Office of Surface Mining Reclamation and Enforcement, 1983, [Draft] Red Rim, Wyoming, petition evaluation document/environmental impact statement: 35-11-425 WEQA 522 SMCRA Evaluation DEQ/OSM-PE-5, p. III-7 to III-9.

\subsection{APPENDICES}

The individual reports on various coal deposits or coal fields in Appendices A through $\mathrm{F}$ detail the assumptions, methodology, and data used to derive and or/revise resources, remaining $\mathrm{DRB}$, and recoverable reserves of strippable coal in Wyoming. 
APPENDIX A. DEMONSTRATED RESERVE BASE OF STRIPPABLE COAL IN THE DAVE JOHNSTON DEPOSIT, POWDER RIVER COAL FIELD, WYOMING. 


\section{List of Tables}

Table 1. Summary table of remaining demonstrated resource base of coal in the Dave Johnston strippable deposit, through December 31, 1990

(in millions of tons)

Table 2. Original and remaining DRB of strippable coal in the Dave

Johnston coal deposit, through December 31, 1990 (in millions of tons)

Table 3. Analyses of School and Badger seams combined

A-5

Table 4. Analyses of Badger seam

Table 5. Analyses of School seam

\section{List of Figures}

Figure 1. Map of the Dave Johnston strippable coal deposit,

Converse County, Wyoming (from Smith and others, 1972).

A-8 
1. Summary. The Dave Johnston coal deposit contains a total of 43.7 million tons of remaining demonstrated reserve base (DRB) of coal through December 31, 1990 (or as of January 1, 1991). All the coal resources contain $15.00-19.99$ million Btu/short ton. The Badger coal seam contains 2.9 million tons of coal with $0.41-0.60 \mathrm{lbs}$ sulfur/million Btu and and the School coal seam contains 40.8 million tons of coal with $0.61-0.83 \mathrm{lbs}$ sulfur/million Btu (Table 1).

Table 1. Summary table of remaining demonstrated resource base of coal in the Dave Johnston strippable deposit, through December 31, 1990 (in millions of tons).

\begin{tabular}{|c|c|c|c|c|}
\hline Seam & $\begin{array}{c}\text { Btu content } \\
\text { (million Btu/shont ton) }\end{array}$ & \multicolumn{2}{|c|}{$\begin{array}{c}\text { Sulfur Content } \\
\text { (lbs sulfur/million Btu) }\end{array}$} & $\begin{array}{c}\text { Total all } \\
\text { Categories }\end{array}$ \\
\hline $\begin{array}{l}\text { Badger } \\
\text { School }\end{array}$ & $\begin{array}{l}15-19.99 \\
15-19.99\end{array}$ & 2.9 & $\overline{40.8}$ & $\begin{array}{r}2.9 \\
40.8\end{array}$ \\
\hline Total & $15-19.99$ & 2.9 & 40.8 & 43.7 \\
\hline
\end{tabular}

2. Methodology and Assumptions. The original strippable coal resources for this deposit were taken from Smith and others (1972). The School and the overlying Badger coal beds occur in the Eocene Wasatch Formation in the southern part of the Powder River Coal Field. Correlation of these coal beds with other named coal beds to the north has not been established. The Badger coal bed averages about 17 feet in thickness and is considered strippable under less than 80 feet of overburden. The School coal bed averages 33.6 feet in thickness and is considered strippable under less than 140 feet of overburden. The interburden between the Badger and the School coal beds ranges from 110 to 180 feet. An additional 45 million tons of reserves in the School coal bed occurs where overburden on top of the School exceeds 140 feet. In this case, overburden above the Badger coal bed is included as part of the overburden above the School and both coal beds can be recovered by multiple-seam mining.

After determining the sulfur contents and heating values for each coal bed (see part 3 , Analyses, below), the reserves for each coal bed were assigned an appropriate heating value and sulfur content category. The remaining strippable resources (DRB) for both beds were determined by subtracting coal production and mining losses from the original strippable coal reserves ('Tâble 2). 
Table 2. Original and remaining DRB of strippable coal in the Dave Johnston coal deposit, through December 31, 1990 (In millions of tons). Numbers in parentheses are negative.

\begin{tabular}{lccc}
\hline & Badger & School & Total \\
\hline $\begin{array}{c}\text { Original strippable DRB } \\
\text { (from Smith, 1972) }\end{array}$ & 9.5 & 126.2 & 135.7 \\
$\begin{array}{l}\text { Production and mining losses } \\
\text { Coal production through 1990 }\end{array}$ & & & \\
Mining losses (80\%) & $(5.3)$ & $(68.3)$ & $(73.6)$ \\
\hline Total coal depleted & $(1.3)$ & $(17.1)$ & $(18.4)$ \\
\hline $\begin{array}{l}\text { Remaining strippable DRB } \\
\text { (through December 31, 1990) }\end{array}$ & $(6.6)$ & $(85.4)$ & $(92.0)$ \\
\hline
\end{tabular}

Production losses were calculated by assuming that the coal actually produced (reported as cumulative production) represents 80 percent of the coal removed from this deposit; the remaining 20 percent of the coal removed represents coal lost or not recovered during mining. Cumulative production and mining losses for each coal bed in the deposit were calculated assuming that the amount of coal from the Badger seam accounts for an average of 7.5 percent of the total coal produced each year.

3. Analyses. Coal analyses used in this report were taken from various sources as detailed on Tables 3,4 , and 5 and plotted on Figure 1. Analyses related only to specific beds were used to categorize the remaining reserve. Seven analyses of the School seam (Table 5) included a weighted average of 12 monthly coal deliveries in 1989. All of the seven analyses had a heating value in the $15-19.99$ million Btu/short ton range. Sulfur contents varied from 0.37 to $1.01 \mathrm{lbs}$ sulfur/million Btu; the average, the weighted average, and the average without using the delivered samples were all in the $0.61-0.83$ lbs sulfur/million Btu range. Because the highest sulfur content sample only represents one-sixth of the total School seam thickness, the value reported is probably anomalous, is not typical of the entire coal seam, and probably doesn't represent a significant area of higher sulfur content. Fourteen analyses of the Badger seam (Table 4) had an average sulfur content of $0.55 \mathrm{lbs}$ sulfur/million Btu and a heat content of 15.93 million Btu/short ton. One analysis from the Badger showed a higher sulfur content than the average but because that analysis came from only one-third of the coal bed, the values reported for this sample are probably anomalous or not indicative of the entire seam. 


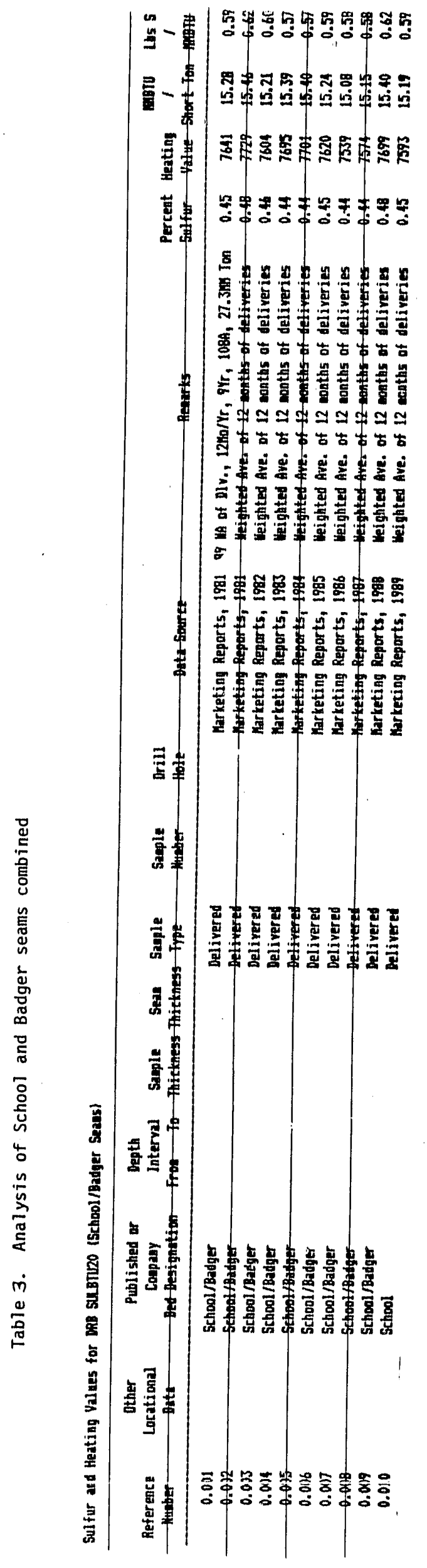




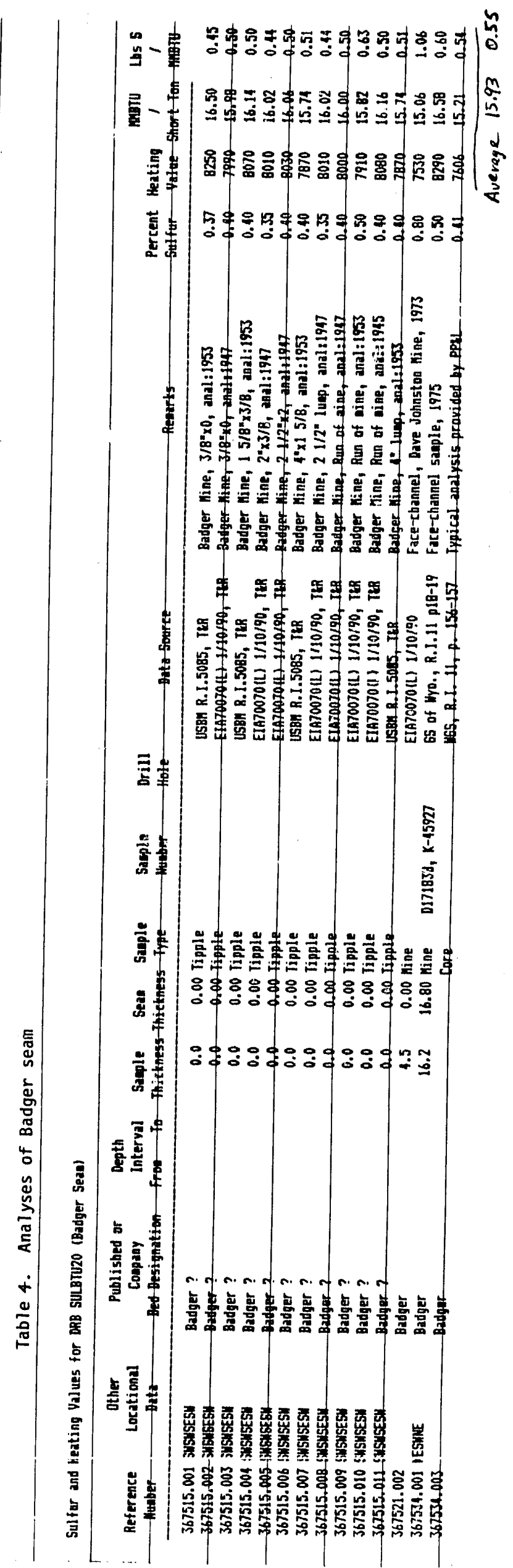




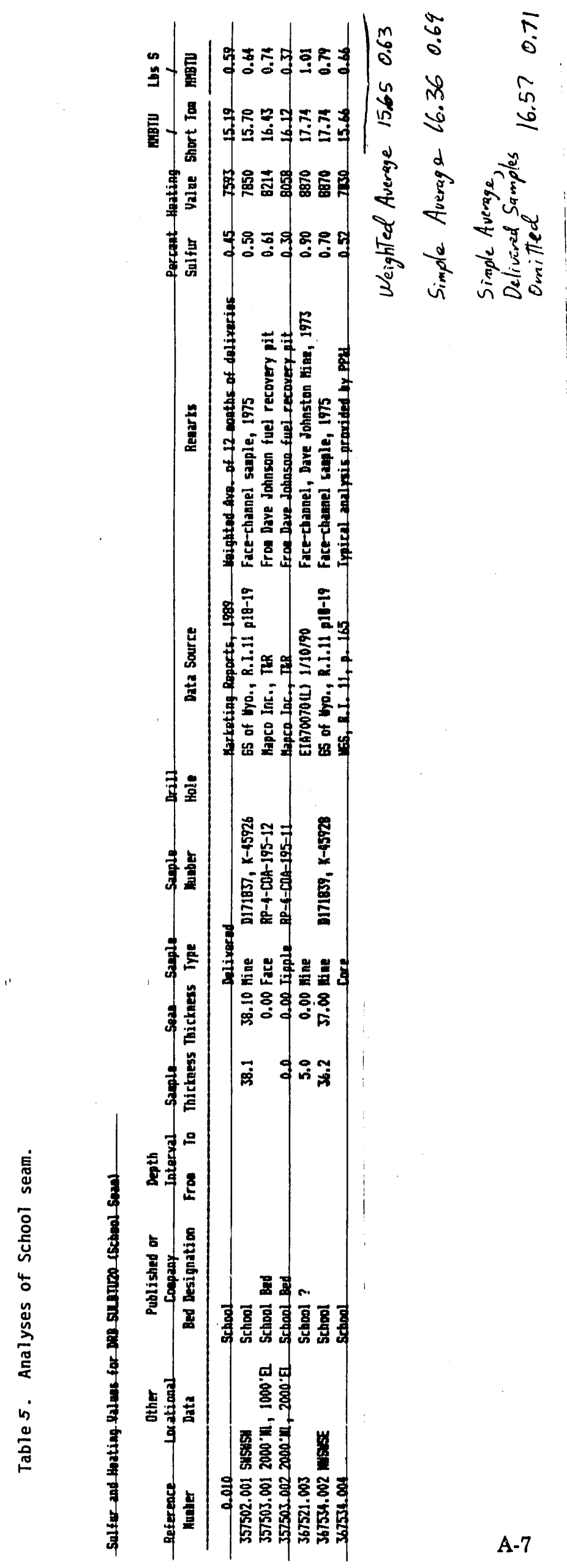




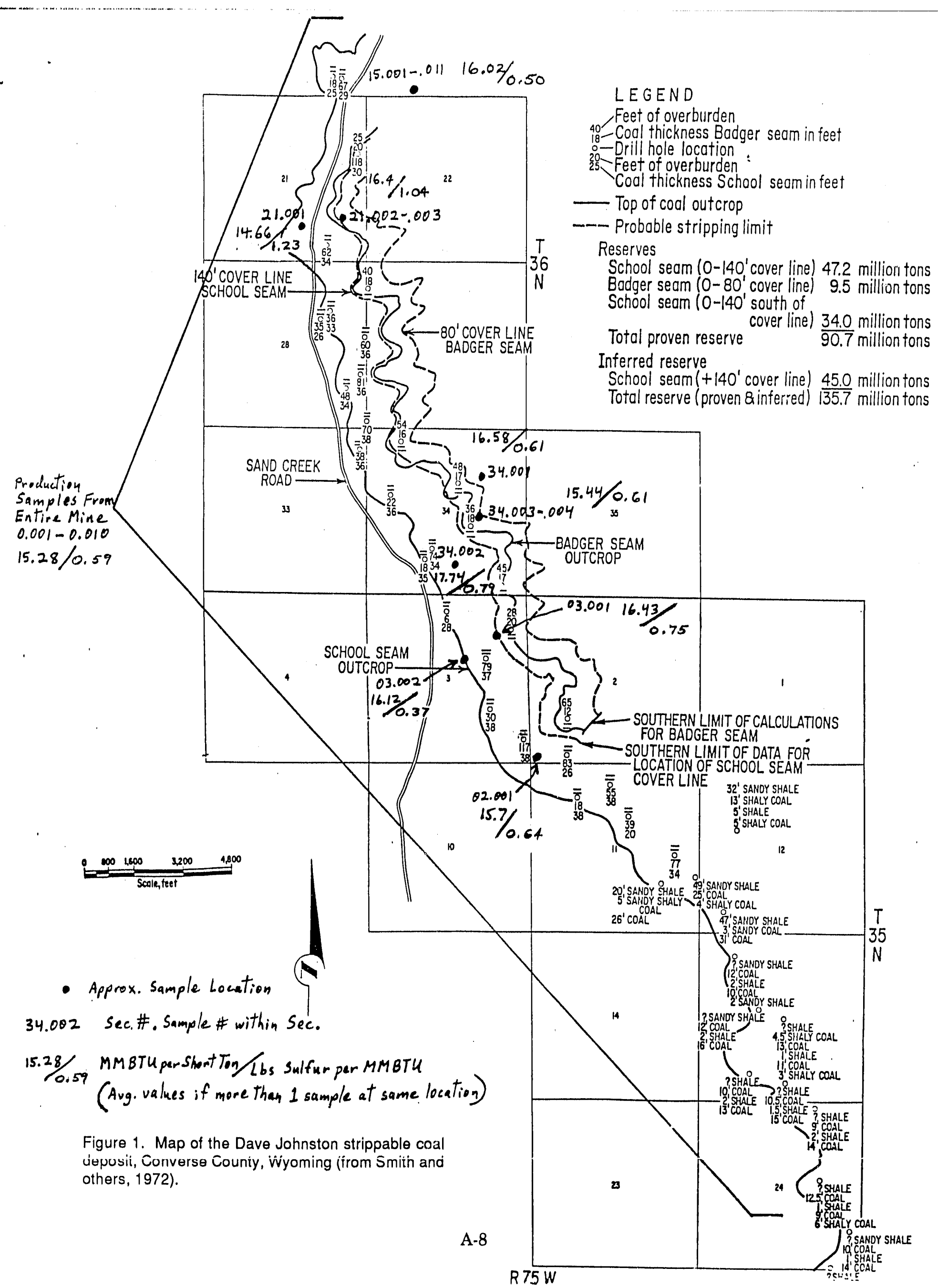


As a check on the coal quality of the entire deposit, 108 analyses from coal delivered between 1981 and 1989 were included as blended coal from both the Badger and the School seams (Table 3). The weighted average for these analyses was 15.28 million Btu/ short ton and 0.59 pounds sulfur/million Btu. Although the blended coal samples are from two separate coal beds, the beds are very similar in composition and are very close to each other stratigraphically. Even though the blended coal samples were only used as a check on the separate bed analyses and were not used to assign the final quality categories to this deposit, it is felt that the blended coal analyses in this case are representative of both the Badger and the School coal seams and the entire strippable deposit.

\section{REFERENCE CITED}

Smith, J.B., Ayler, M.F., Knox, C.C., and Pollard, B.C., 1972, Strippable coal reserves of Wyoming: U.S. Bureau of Mines Information Circular 8538, 51 p. 
APPENDIX B. DEMONSTRATED RESERVE BASE OF STRIPPABLE COAL IN THE WYODAK-CABALLO CREEK DEPOSIT, EASTERN POWDER RIVER COAL FIELD, WYOMING. 


\section{List of Tables}

Page

Table 1. Summary of remaining demonstrated reserve base (DRB)

of the Wyodak and other coal seams in the Wyodak-Caballo

Creek deposit through December 31, 1990 (in million short tons)

Table 2. In-place and remaining DRB for the Wyodak coal

bed in the Wyodak-Caballo Creek deposit, eastern part

of the Powder River Coal Field (in million short tons)

Table 3. Coal production and mining for the Wyodak

coal bed by sulfur contents (in million short tons)

Table 4A-G. Sulfur and heating values for the Wyodak,

Felix, C", C', C, Lower Ulm, and Scott coal beds

Table 5. Delivered sulfur and heating values, by mine, for Wyodak coal production

\section{List of Figures}

Figure 1. Sulfur contents and isopach map of the Wyodak-Caballo

Creek deposit (modified from Smith and others, 1972).

Figure 2. Weighted average sulfur and heating contents, by

Township, for the Caballo Creek area, Felix coal bed

Figure 3. Weighted average sulfur and heating contents, by Township,

for the Caballo Creek area, C', C', C, Lower Ulm, and Scott coal beds

Figure 4. Sulfur contents of delivered coal, by mine, for

the Wyodak coal bed, Wyodak-Caballo Creek deposit.

Figure 5. Correlation of coal beds in the Wasatch and Fort Union

Formations, Powder River Coal Field, Wyoming (from Glass and Jones, 1991) 
1. Summary. The remaining demonstrated reserve base (DRB) of strippable coal in the Wyodak and other coal beds in the Wyodak-Caballo Creek deposit is about 19.2 billion tons (see Table 1). The DRB includes the Wyodak coal bed under less than 200 feet of cover within the eastern part of the Powder River Coal Field plus additional strippable coal beds within the Caballo Creek area (see Figures 1-3). The Wyodak coal bed alone accounts for about 17.9 billion tons or 94 percent of the total.

The entire DRB for the Wyodak is in the heating value category of 15 - 19.99 million Btu/short ton (Table 1). Of the 17.9 billion short tons of coal in the Wyodak DRB, about 4.9 billion tons (or 28 percent ) of the coal contains less than $0.40 \mathrm{lbs}$ sulfur/million Btu, about 9.2 billion tons (or 51 percent) contains $0.41-0.60 \mathrm{lbs}$ sulfur/million Btu, and about 3.8 billion tons (or 21 percent) contains $0.61-0.83 \mathrm{lbs}$ sulfur/million Btu.

The DRB for other coal beds (stratigraphically above the Wyodak) in the Caballo Creek area is about 1.3 billion tons. Like the Wyodak, most of the coal in this area is also in the heating value category of $15-19.99$ million Btu/short ton (Table 1). Most of the 1.3 billion tons contains $0.61-1.67 \mathrm{lbs}$ sulfur/million Btu; about 11 percent of the 1.3 billion tons of coal contains more than $1.68 \mathrm{lbs}$ sulfur/million Btu.

Table 1. Summary of remaining demonstrated reserve base (DRB) of the Wyodak and other coal seams in the Wyodak-Caballo Creek deposit through December 31, 1990 (in million short tons).

\begin{tabular}{|c|c|c|c|c|c|c|c|c|}
\hline \multirow[b]{2}{*}{ Seam } & \multirow{2}{*}{$\begin{array}{l}\text { Btu Content } \\
\text { (million Btu/ } \\
\text { sliort ton) }\end{array}$} & \multicolumn{6}{|c|}{$\begin{array}{l}\text { Sulfur Content: } \\
\text { (lbs sulfur/million Btu) }\end{array}$} & \multirow{2}{*}{$\begin{array}{c}\text { Total } \\
\text { All Sulfur } \\
\text { Categories }\end{array}$} \\
\hline & & $\leq 0.40$ & $0.41-0.60$ & $0.61-0.83$ & $0.84-1.67$ & $1.68-2.50$ & $>2.50$ & \\
\hline Wyodak & $15-19.99$ & $4,892.1$ & $9,178.3$ & $3,816.4$ & - & - & - & $17,886.8$ \\
\hline Fellix & $15-19.99$ & - & - & 304.1 & 755.9 & - & - & $1,060.0$ \\
\hline Lower UIm & $15-19.99$ & - & - & - & 27.0 & 16.8 & - & 43.8 \\
\hline Scott & $<15$ & - & - & - & 13.5 & - & - & 13.5 \\
\hline \multirow[t]{2}{*}{ C" bed } & $<15$ & - & - & - & - & - & 6.5 & 6.5 \\
\hline & $15-19.99$ & - & - & - & - & - & 4.6 & 4.6 \\
\hline C' bed & $15-19.99$ & - & - & - & - & - & 115.2 & 115.2 \\
\hline $\mathrm{C}$ bed & $15-19.99$ & - & - & - & 26.3 & - & - & 26.3 \\
\hline Total & $<15$ & - & - & - & 13.5 & - & 6.5 & 20.0 \\
\hline \multirow[t]{3}{*}{ All beds } & $15-19.99$ & $4,892.1$ & $9,178.3$ & $4,120.5$ & 809.2 & 16.8 & 119.8 & $19,136.7$ \\
\hline & Total All & & & & & & & \\
\hline & Btu Categories & $4,892.1$ & $9,178.3$ & $4,120.5$ & 822.7 & 16.8 & 126.3 & $19,156.7$ \\
\hline
\end{tabular}




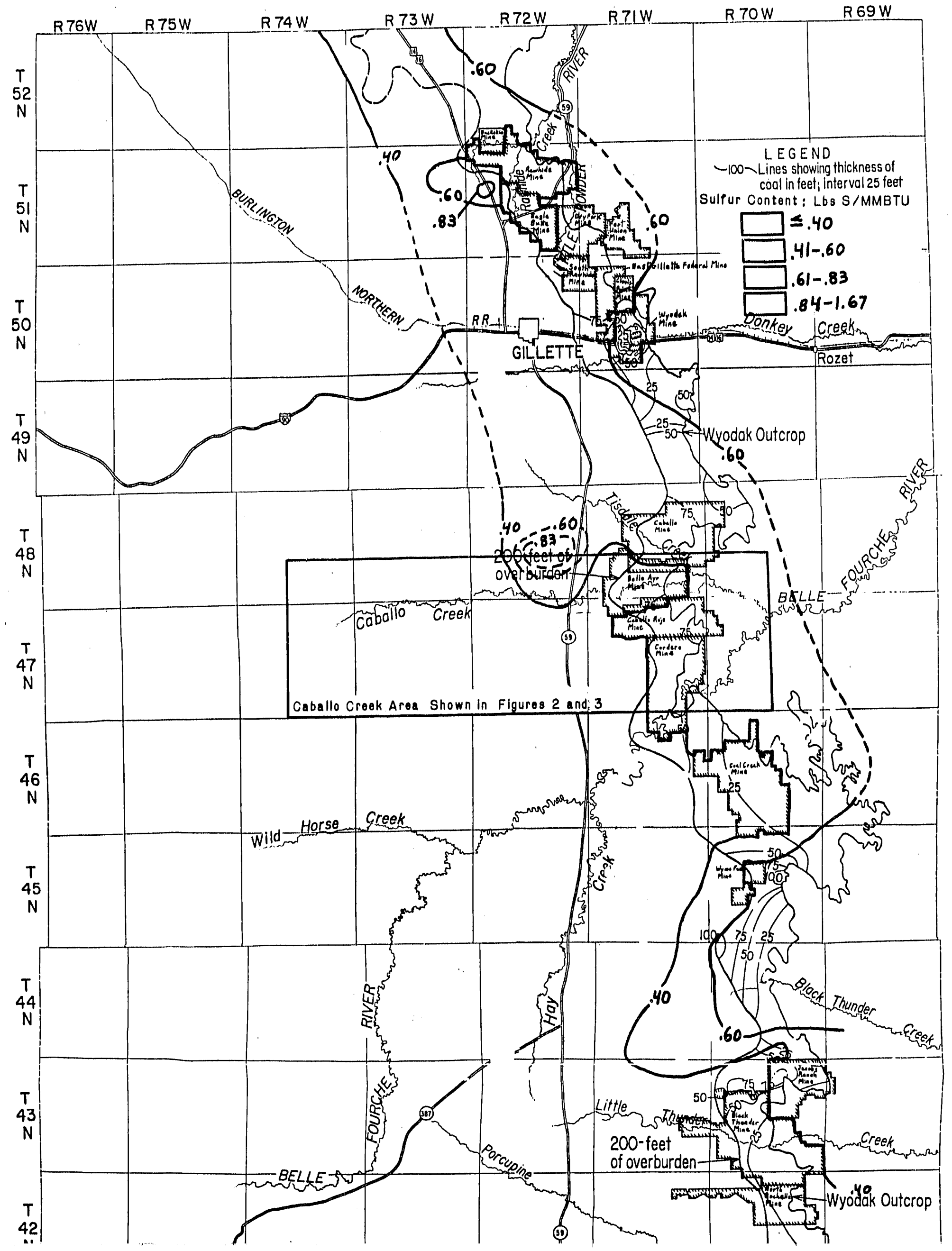




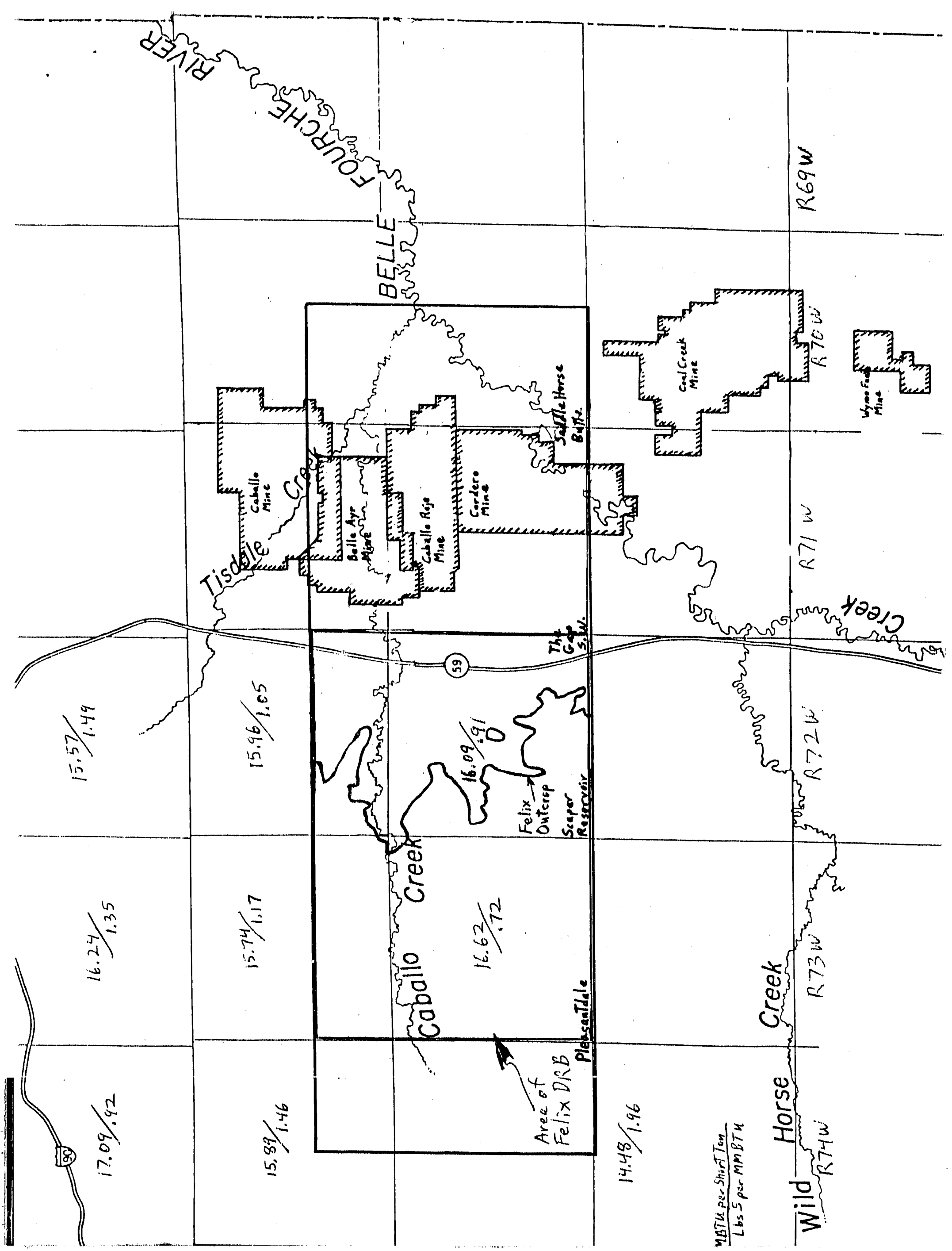




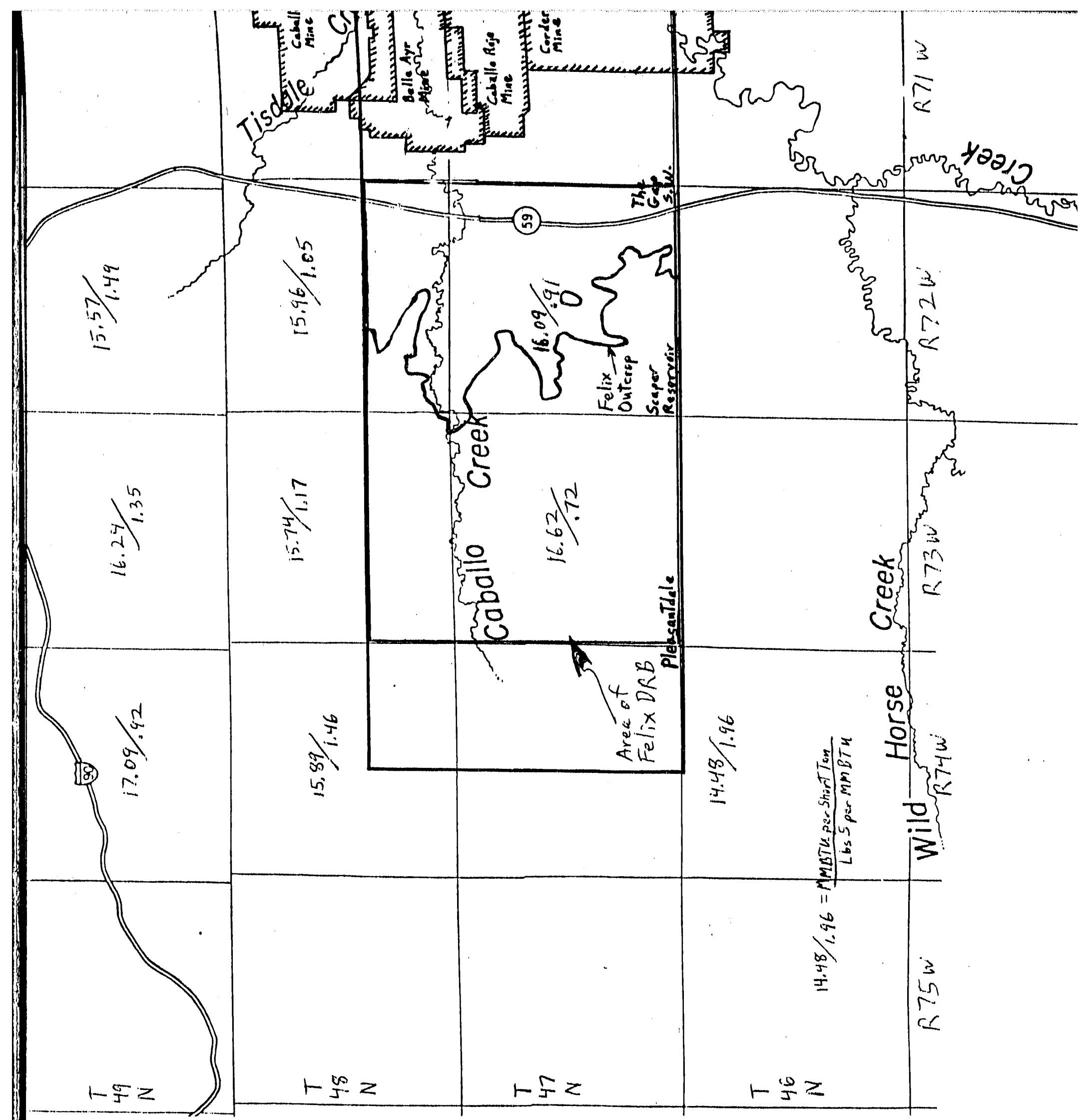

Figure 2. Weighted average sulfur and heating contents, by Township, for the Caballo Creek area, Fellx coal bed. 


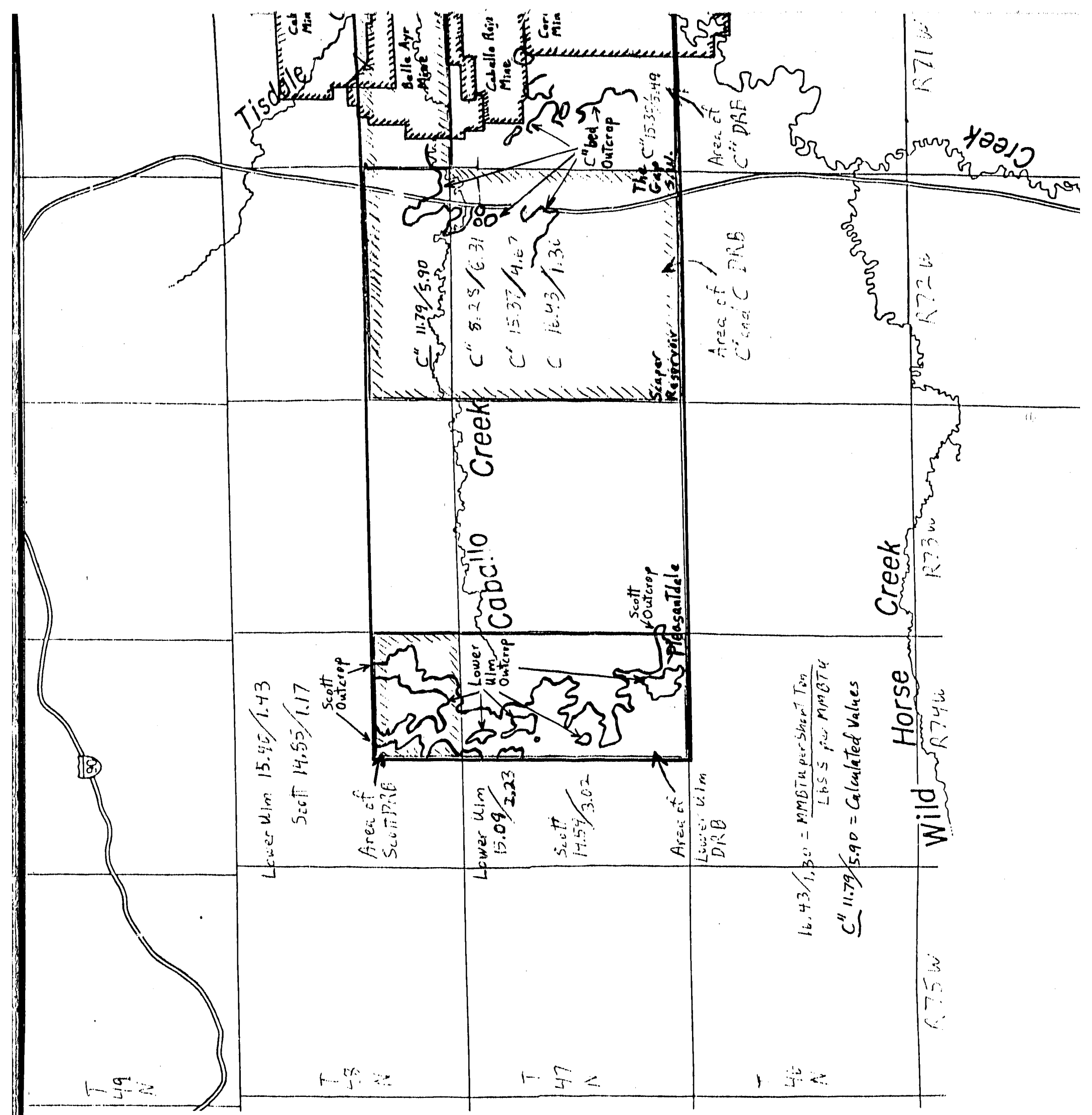

Figure 3. Welghted average sulfur and heating contents, by Township, for the Caballo Creek area, C", C', C, Lower Uim, and Scott coal beds. 
2. Methodology and Assumptions. Original strippable DRB by sulfur content for the Wyodak was derived by planimetering the original coal resource map (Figure 1) from Smith and others (1972), on which were superimposed iso-sulfur lines that subdivide the different sulfur content categories. Original resources for the Wyodak coal bed present in the Caballo Creek area were subtracted from the original strippable DRB and replaced with new coal resources estimated by Grazis (1977) for that area. Calculations for remaining strippable DRB for the Wyodak coal bed are shown in Table 2. Mining and production losses for the Wyodak coal bed (Table 3 ) were subtracted from the adjusted DRB to calculate the remaining strippable DRB.

Table 2. In-place and remaining DRB for the Wyodak coal bed in the Wyodak-Caballo Creek deposit, eastern part of the Powder River Coal Field (in million short tons). Numbers in parentheses are negative.

\begin{tabular}{|c|c|c|c|c|c|c|c|c|}
\hline & \multirow{2}{*}{$\begin{array}{l}\text { Btu Content } \\
\text { (milllon Btu/ } \\
\text { short ton) }\end{array}$} & \multicolumn{6}{|c|}{$\begin{array}{l}\text { Sulfur Content } \\
\text { (lbs sulfur/million Btu) }\end{array}$} & \multirow{2}{*}{$\begin{array}{l}\text { Total } \\
\text { All Sulfur } \\
\text { Categories }\end{array}$} \\
\hline & & $\leq 0.40$ & $0.41 \cdot 0.60$ & $0.61-0.83$ & $0.84-1.67$ & $1.68 \cdot 2.50$ & $>2.50$ & \\
\hline $\begin{array}{l}\text { A. Original strippable } \\
\text { DRB from Smith, } \\
\text { et.al. (1972) }\end{array}$ & $15-19.99$ & $5,856.9$ & $9,263.7$ & $3,873.2$ & - & - & - & $19,003.8$ \\
\hline \multicolumn{9}{|c|}{ Caballo Creok Adjustment } \\
\hline $\begin{array}{l}\text { B. Subtract Smith, et.a } \\
\text { (1972) }\end{array}$ & $15-19.99$ & (970.5) & (42.1) & - & - & - & - & $(1,012.6)$ \\
\hline $\begin{array}{l}\text { C. Add Grazis } \\
(1977)\end{array}$ & $15-19.99$ & 890.0 & 479.3 & - & $\cdots$ & - & - & $1,369,3$ \\
\hline $\begin{array}{l}\text { D. Total adjustment } \\
(B+C)\end{array}$ & $15-19.99$ & $(80.5)$ & 437.2 & - & - & - & - & 356.7 \\
\hline $\begin{array}{l}\text { E. Adjusted original } \\
\text { DRB }(A+D)\end{array}$ & $15-19.99$ & $5,786.4$ & $9,700.9$ & $3,873.2$ & - & - & - & $19,360.5$ \\
\hline $\begin{array}{l}\text { F. Coal production } \\
\text { through } 1990\end{array}$ & $15-19.99$ & (804.9) & $(470.3)$ & $(51.1)$ & - & - & - & $(1,326.3)$ \\
\hline $\begin{array}{l}\text { G. Mining losses } \\
(90 \% \text { recovery) }\end{array}$ & 15-19.99 & (89.4) & (42.3) & $(5.7)$ & - & - & - & $(147.4)$ \\
\hline $\begin{array}{l}\text { H. Total coal } \\
\text { depleted }(F+G)\end{array}$ & $15-19.99$ & $(894.3)$ & $(522.6)$ & $(56.8)$ & - & - & - & $(1,473,7)$ \\
\hline $\begin{array}{l}\text { I. Remaining } \\
\text { strippable DRB } \\
\text { through } 12 / 31 / 90 \\
(E+H)\end{array}$ & & $4,892.1$ & $9,178.3$ & $3,816.4$ & - & - & - & $17,886.8$ \\
\hline
\end{tabular}


Table 3. Coal production and mining for the Wyodak coal bed by sulfur contents ${ }^{1}$ (in million short tons).

\begin{tabular}{|c|c|c|c|c|c|}
\hline \multirow[b]{2}{*}{ Mine Name } & \multirow{2}{*}{$\begin{array}{l}\text { Average } \\
\text { Sulfur Content }{ }^{1} \\
\text { (lbs sulfur/ } \\
\text { million Btu) }\end{array}$} & \multicolumn{3}{|c|}{$\begin{array}{c}\text { Sulfur Content } \\
\text { (lbs sulfur/million Btu) }\end{array}$} & \multirow{2}{*}{$\begin{array}{c}\text { Total } \\
\text { all sulfur } \\
\text { Categories }\end{array}$} \\
\hline & & $\leq 0.40$ & $0.41-0.60$ & $0.61-0.83$ & \\
\hline Belle Ayr & 0.39 & 215.6 & & & 215.6 \\
\hline Eagle Butte & 0.38 & 132.7 & & & 132.7 \\
\hline Caballo & 0.52 & & 95.2 & & 95.2 \\
\hline Rawhide & 0.40 & 112.3 & & & 112.3 \\
\hline Cordero & 0.45 & & 124.3 & & 124.3 \\
\hline Dry Fork & 0.45 & & 0.8 & & 0.8 \\
\hline Ft. Union & 0.48 & & 2.6 & & 2.6 \\
\hline Clovis Point & 0.52 & & 18.1 & & 18.1 \\
\hline Jacobs Ranch & 0.55 & & 142.3 & & 142.3 \\
\hline Caballo Rojo & 0.42 & & 43.7 & & 43.7 \\
\hline N. Antelope & 0.22 & 41.1 & & & 41.1 \\
\hline Rochelle & 0.26 & 41.8 & & & 41.8 \\
\hline N. Rochelle & 0.29 & 0.0 & & & 0.0 \\
\hline Black Thunder & 0.39 & 233.4 & & & 233.4 \\
\hline Coal Creek & 0.39 & 11.8 & & & 11.8 \\
\hline Buckskin & 0.57 & & 43.3 & & 43.3 \\
\hline Wyodak & 0.75 & & & 51.1 & 51.1 \\
\hline Antelope (NERCO) & 0.32 & 16.2 & & & 16.2 \\
\hline Antelope (Brannon) & 0.32 & 0.0 & & & 0.0 \\
\hline Total production & . & 804.9 & 470.3 & 51.1 & $1,326.3$ \\
\hline Total mining loss 2 & & 89.4 & 42.3 & 5.7 & 147.4 \\
\hline \multicolumn{6}{|l|}{ Total production } \\
\hline and mining loss & & 894.3 & 522.6 & 56.8 & $1,473.7$ \\
\hline
\end{tabular}

'Based on selected delivery analyses 1986-1990.

2 Based on $90 \%$ recovery factor.

Because mine-specific recovery factors were not available, it was assumed that surface mines in this portion of the Powder River Coal Field recover about 90 percent of the total coal in-place; the remaining 10 percent of the coal in-place is not recovered because of mining losses and other inefficiencies. For the Wyodak coal bed, it was possible to categorize the coal production and mining losses by sulfur content, using coal delivery data (Table 3). 
Estimates of strippable DRB for other coal beds in the Caballo Creek deposit (Figures 2 and 3) were taken from Grazis, 1977. Sulfur contents and heating values were assigned to each coal bed by determining weighted averages for each Township underlain by strippable coal beds. See Tables $4 \mathrm{~B}$ (Felix coal bed), 4C (C" coal bed), 4D (C) cnal hed), 4F, (C, rnal bed), 4F (Lower Ulm), and 4G (Scott coal bed). Because none of these coal beds have been mined, no adjustments to the original strippable DRB were necessary. A total remaining strippable DRB for the entire area, including the coal beds in the Caballo Creek area plus the Wyodak, was also calculated (Table 1).

3. Analyses. Coal analyses used in this report were taken from various sources as detailed in Tables 4 and 5 . Selected coal delivery data from producing coal mines were used for characterizing mine permit areas (Figure 4). Analyses related only to the specific coal beds included in the DRB were used to assign coal quality categories to the DRB. Analyses from more than 700 core, channel, and tipple samples were examined for this strippable deposit. The lateral variation in sulfur content (in lbs sulfur/million Btu) and heating content (in million Btu/short ton) for the Wyodak coal bed was determined by constructing iso-Btu and iso-sulfur maps from the coal quality data.

All analyses were evaluated on an individual basis. Analyses from unknown coal beds or poorly located data points were not used. Where only partial thicknesses of a coal bed were sampled and analyzed and no other information was available nearby, the data were not considered representative of the entire coal bed and were not used in this study. Where only partial thicknesses of a coal bed were sampled and analyzed and there was other information on coal thickness and quality (of complete coal beds) available nearby, the analyses were weighted by linear footage sampled.

4. Wyodak. The Wyodak coal bed occurs at or near the top of the Paleocene Fort Union Formation and is found in a large area both north and south of Gillette (Figure 5). The Wyodak can occur as a single thick coal bed or as a coal zone with as many as five individual coal beds. Because it splits into two major coal seams both south and west of the Gillette area, the Wyodak is also called the Anderson-Canyon or the WyodakAnderson (Glass ana Jones, 1991). The total thickness of the Wyodak coal bed (or coal beds in the zone) ranges from 25 to 175 feet. 


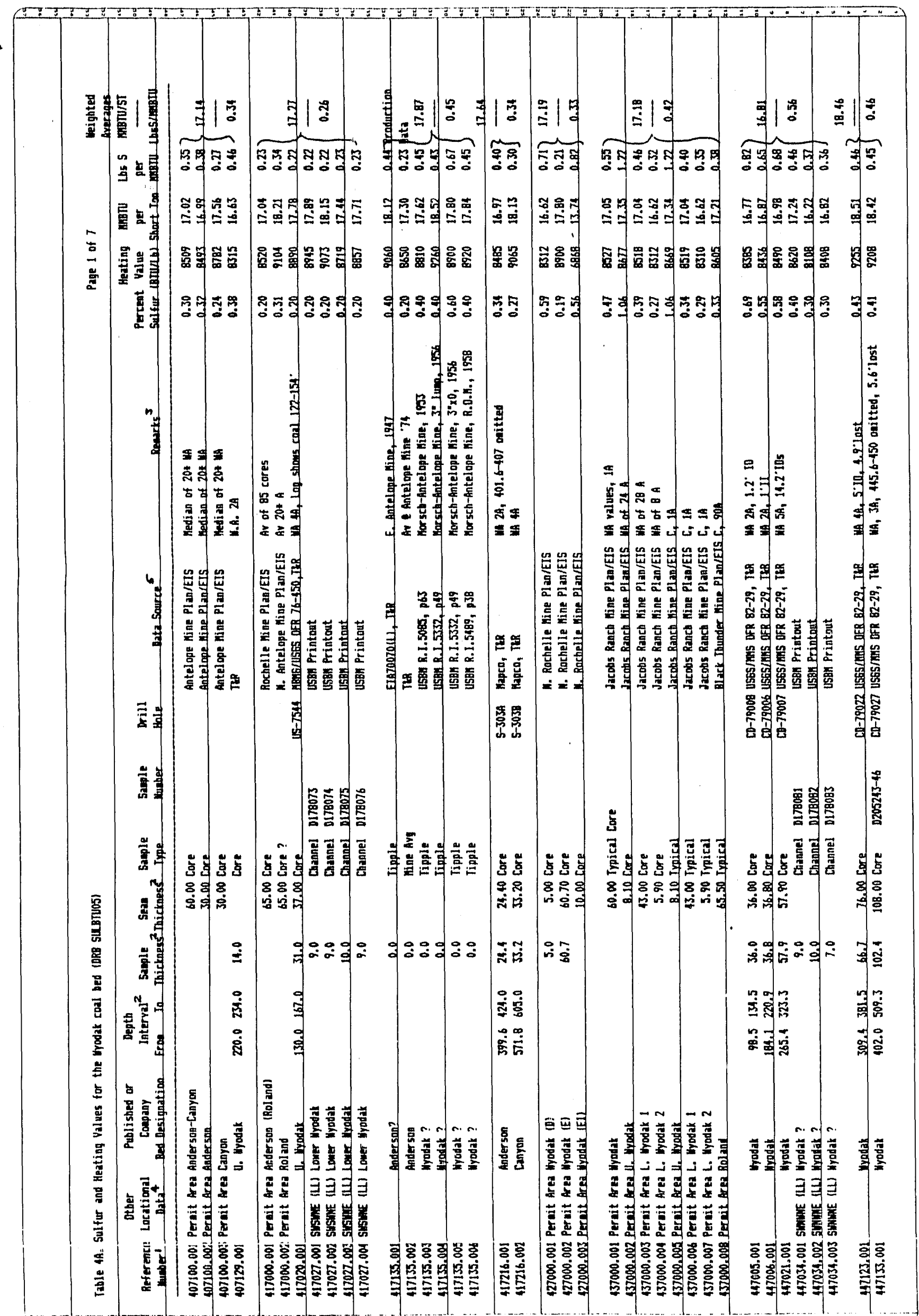

B-10 


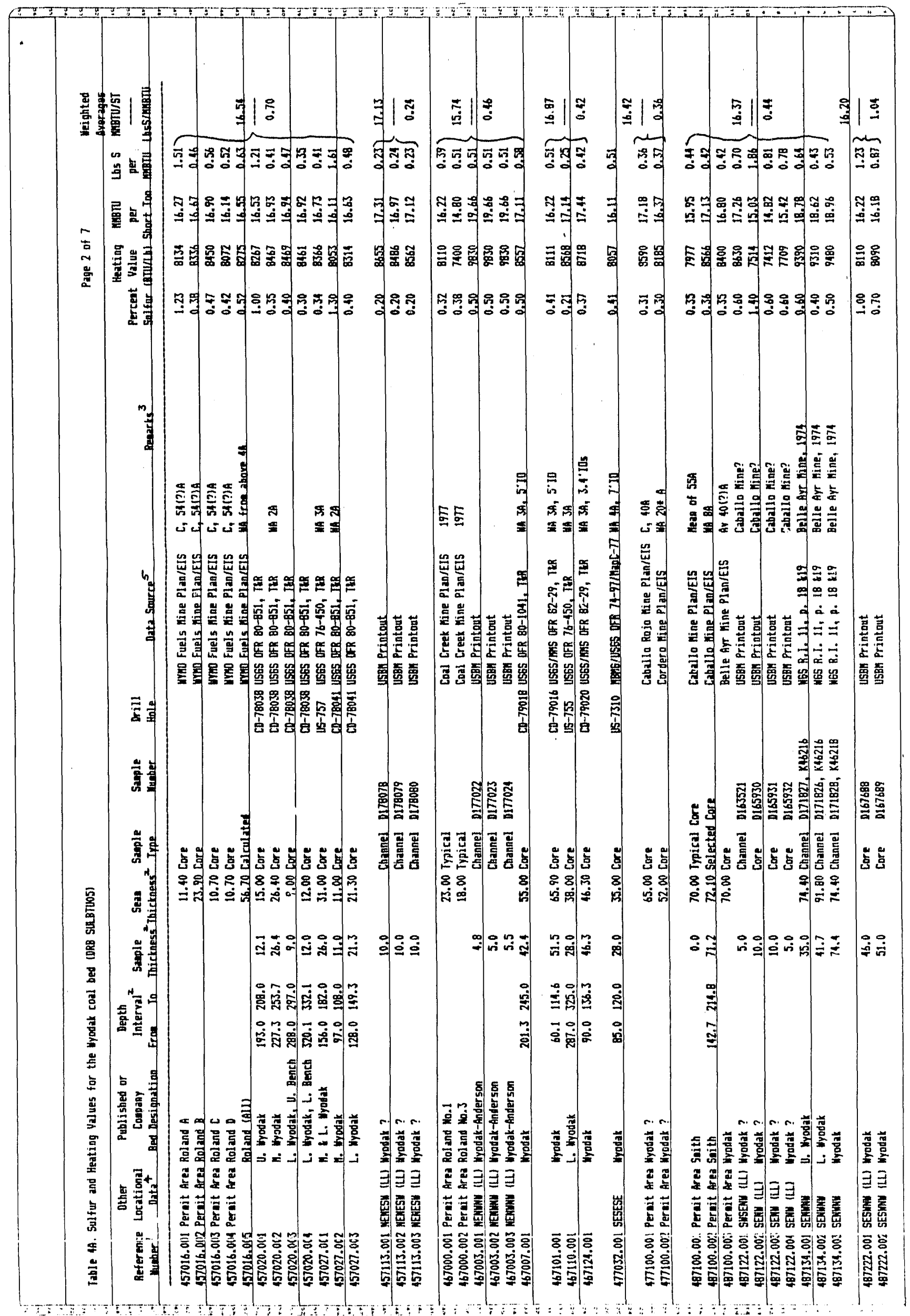

B. 11 


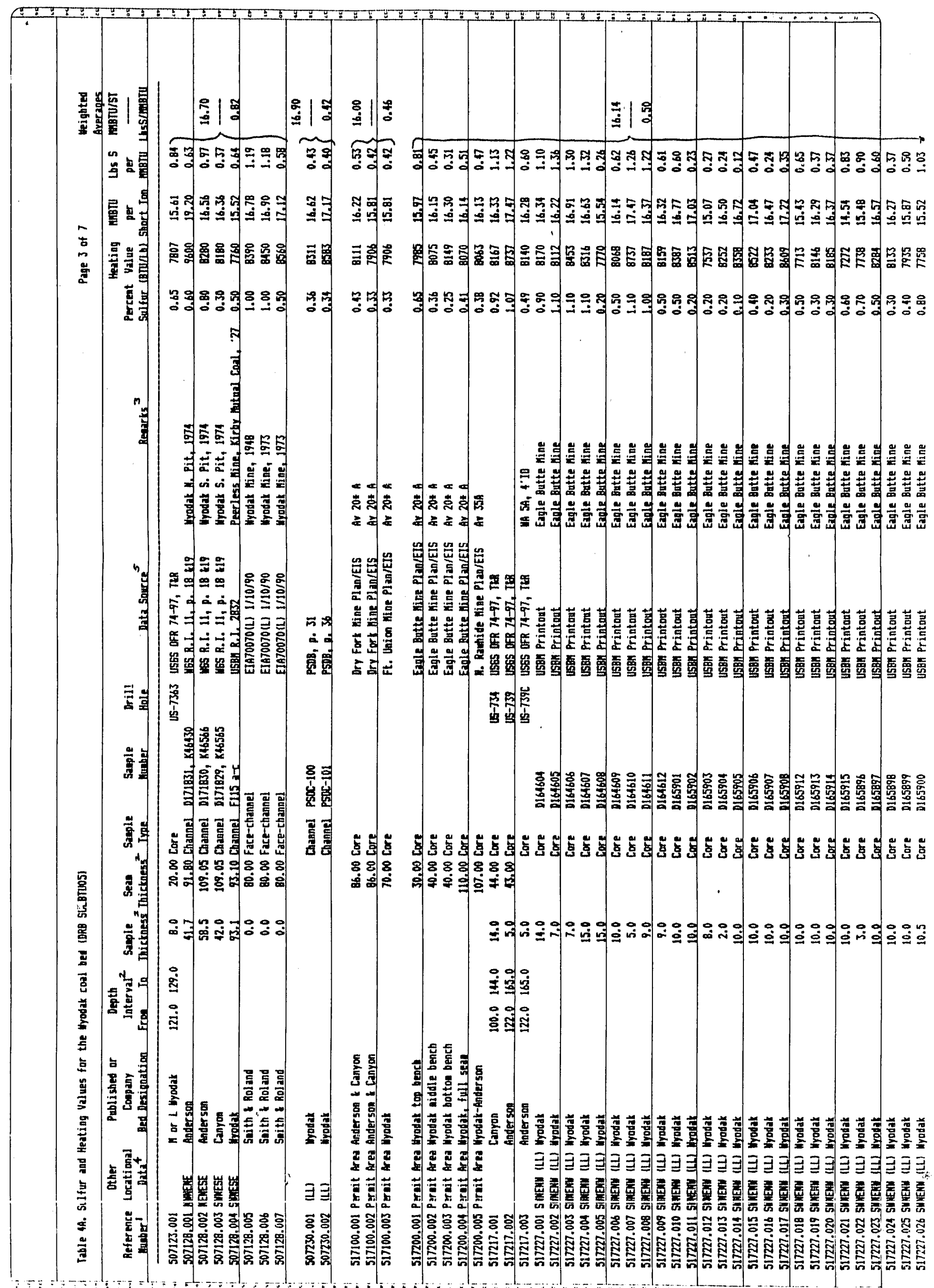

B-12 


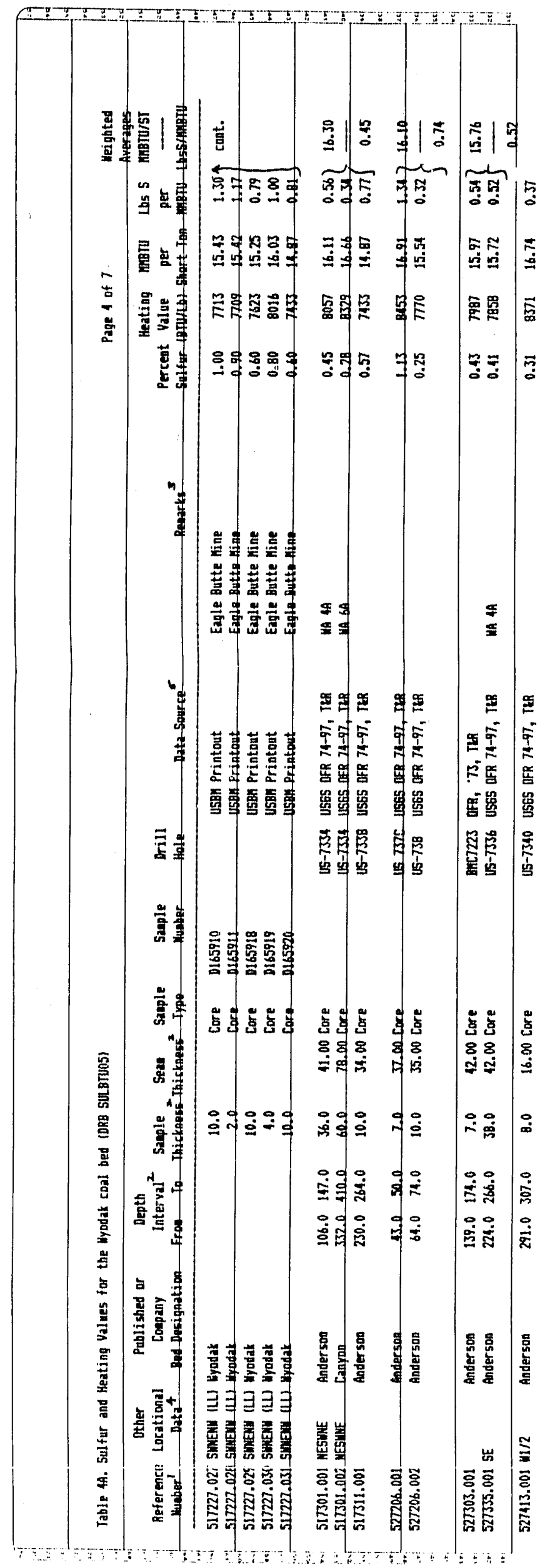




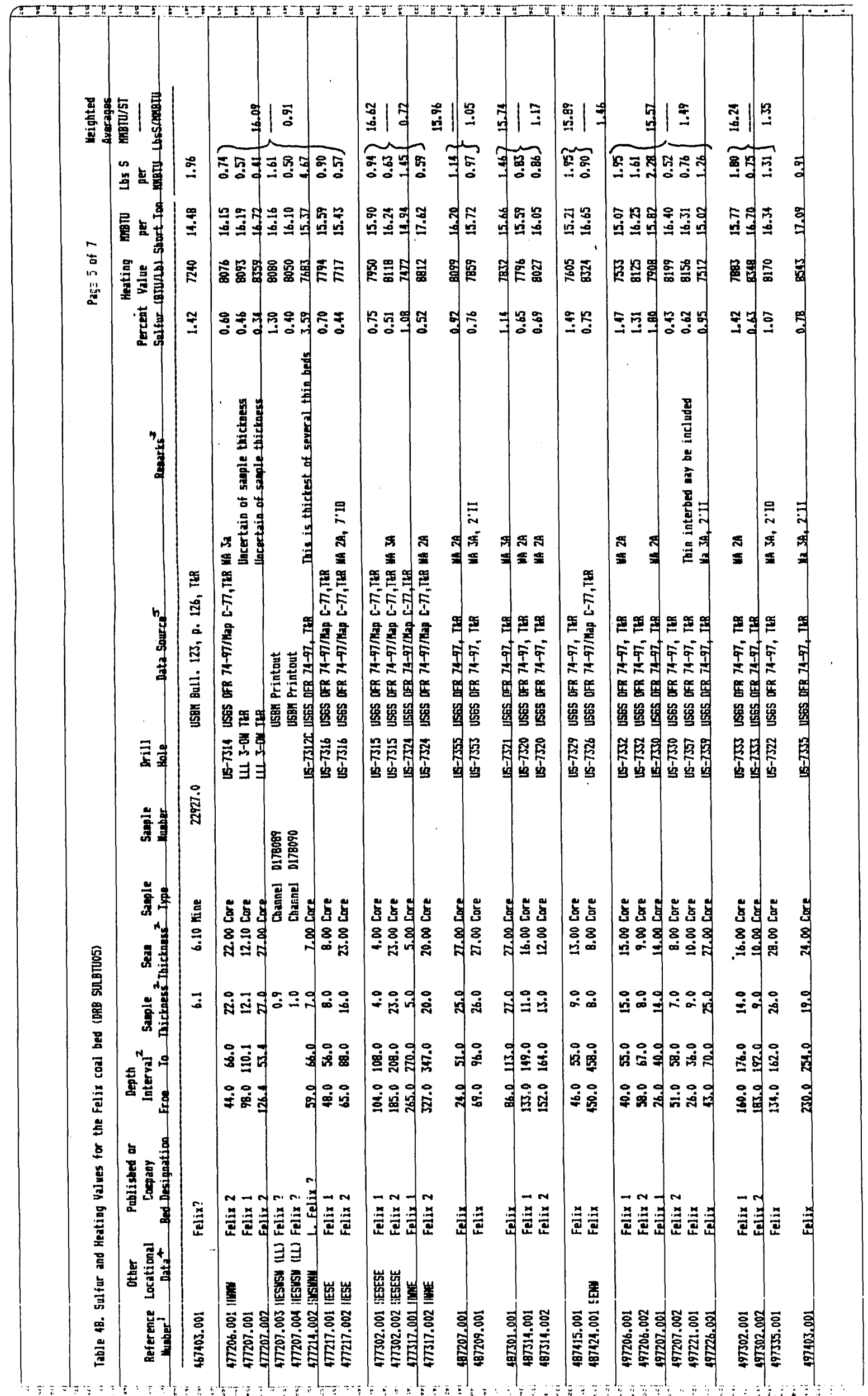

B-14 


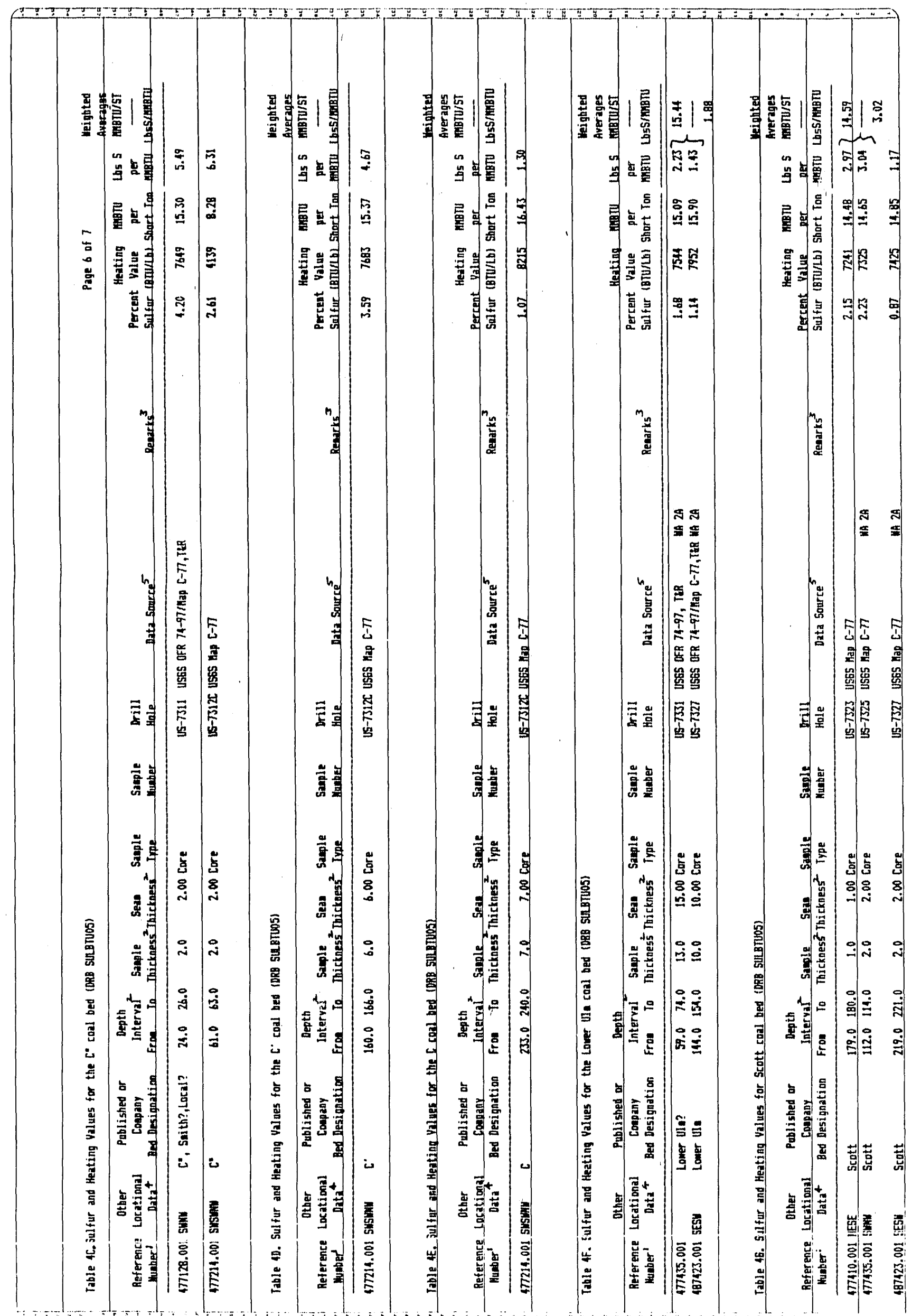




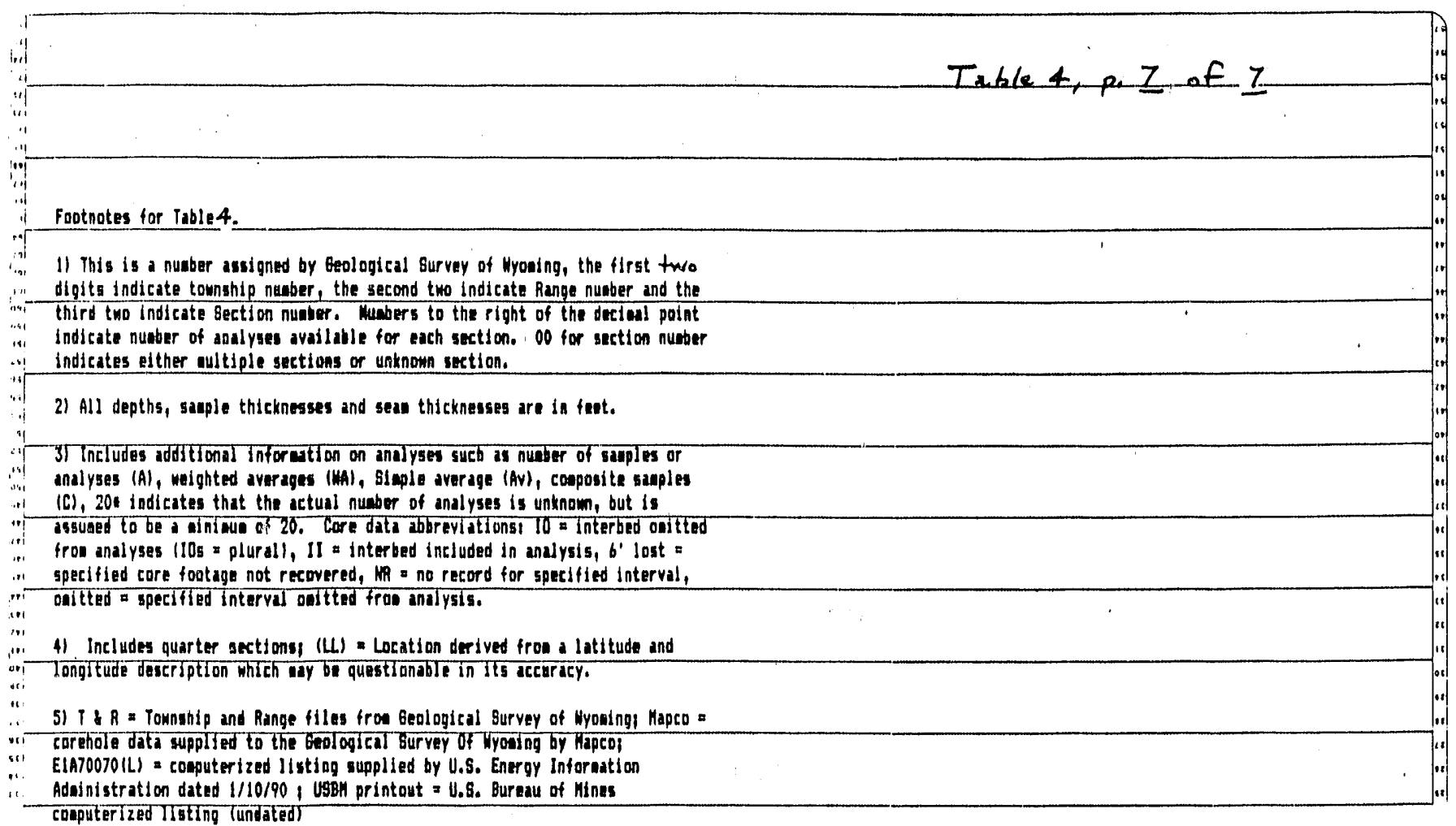




|

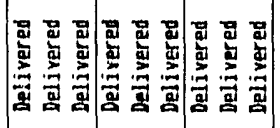

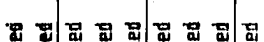

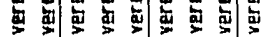

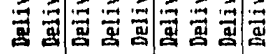

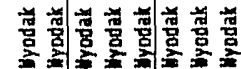

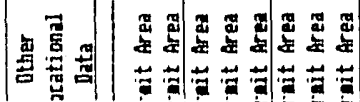

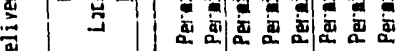
ป

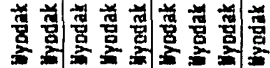

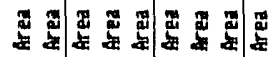

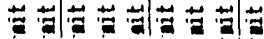

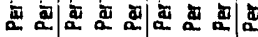
5. ํㅕㅇ

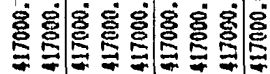

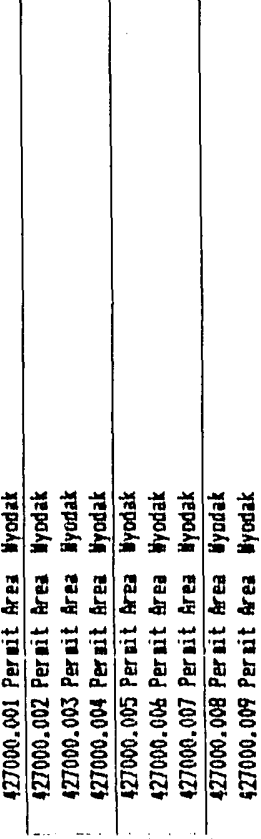

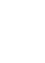

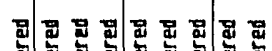

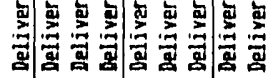

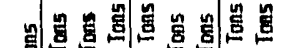
둥 I $x$ a $=$

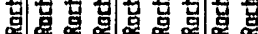

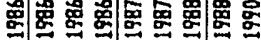

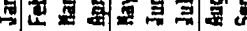
(1)

\section{B-17}




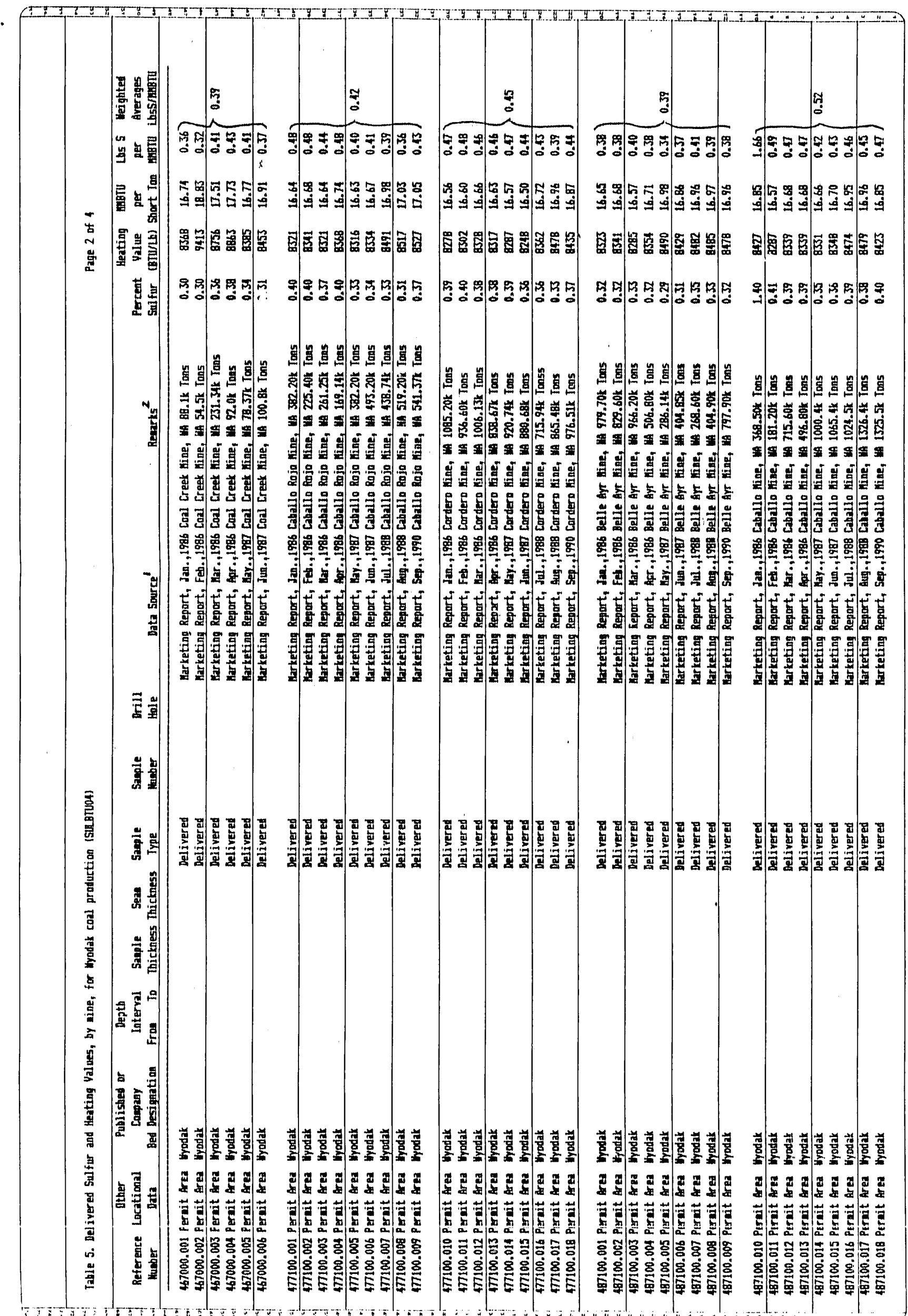

B-18 


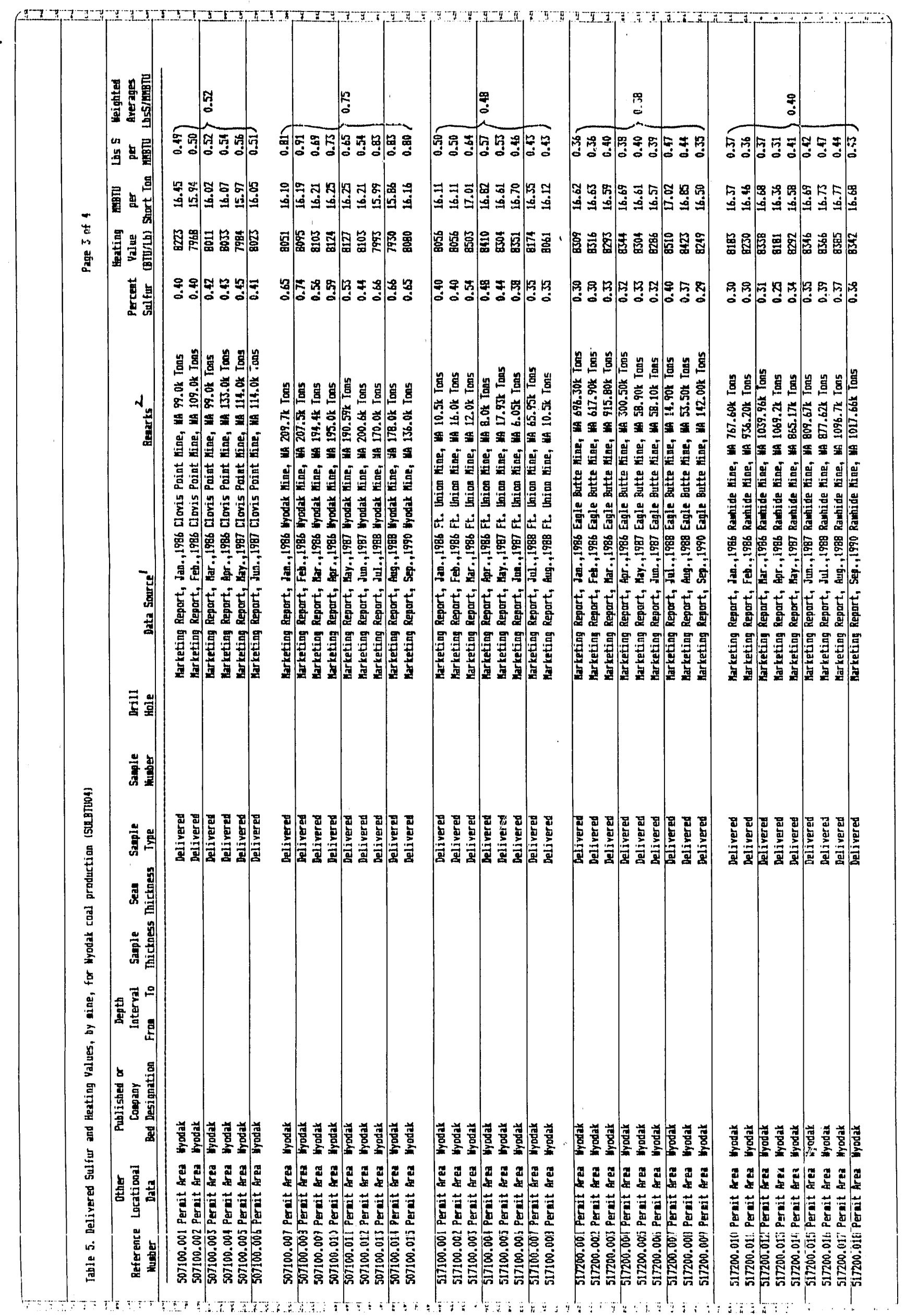

B-19 


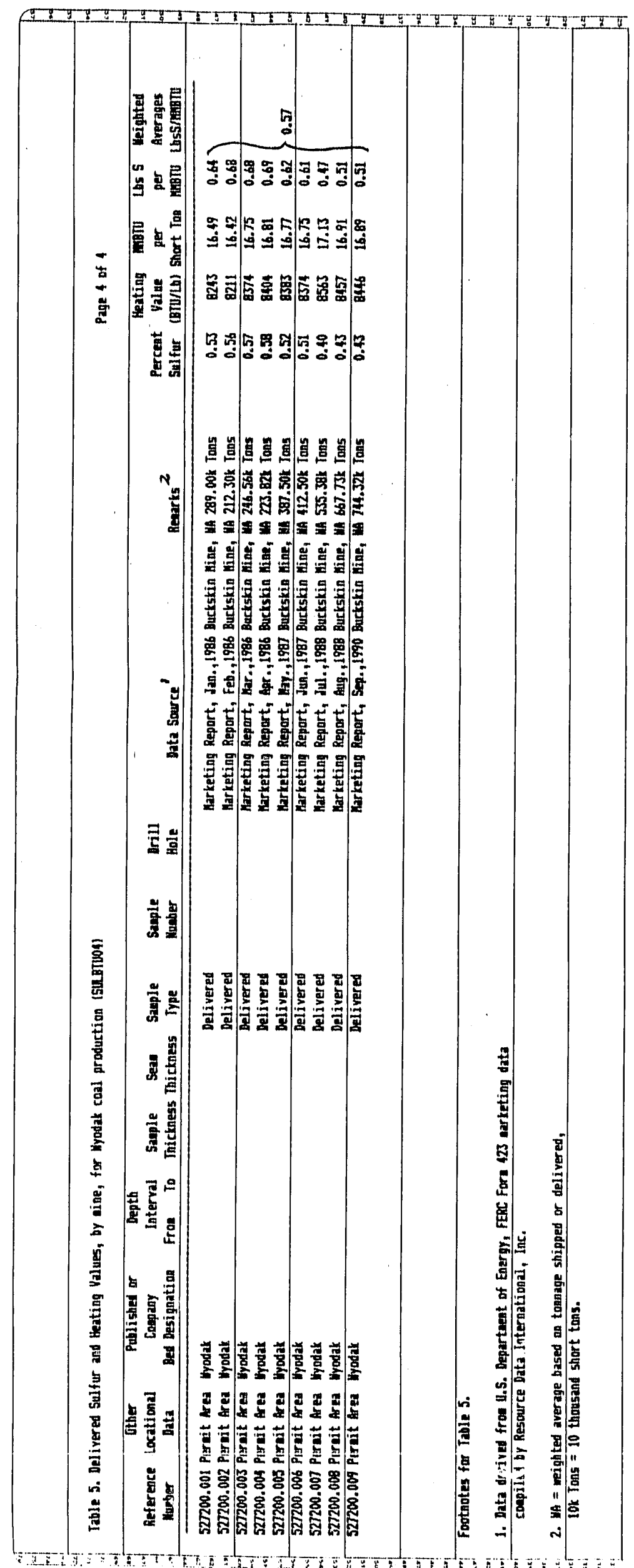

B-20 


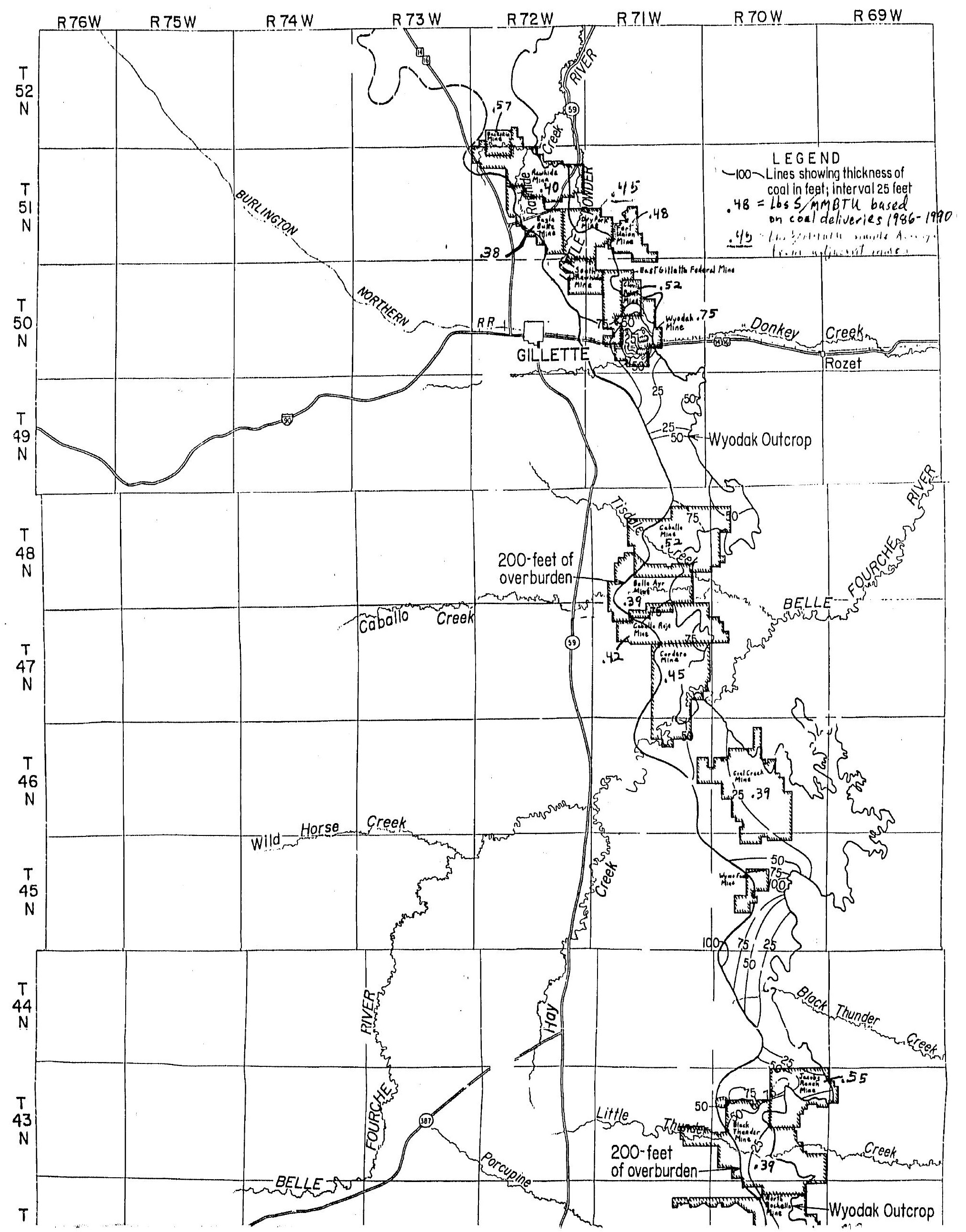




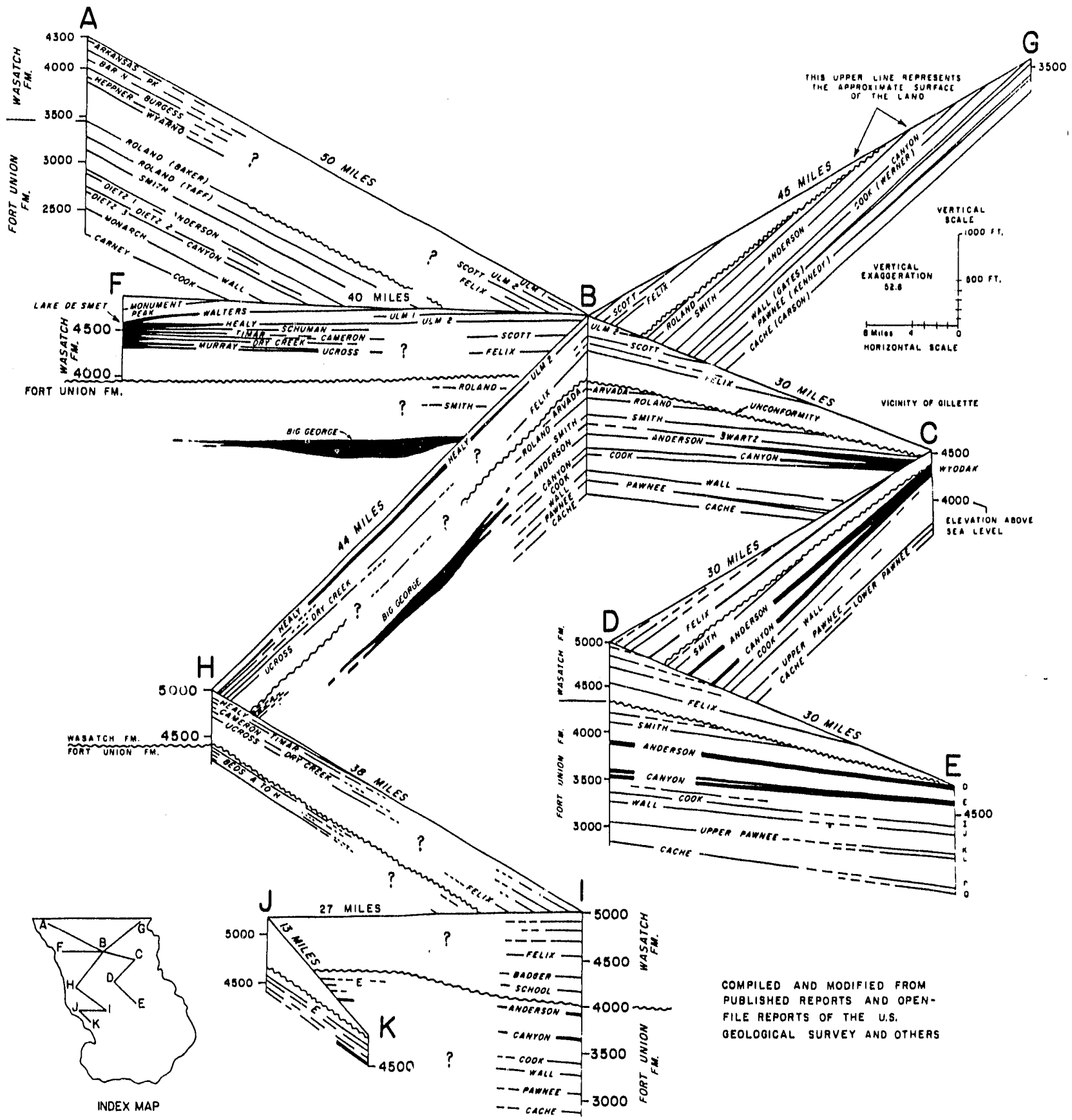

Figure 5. Correlation of coal beds in the Wasatch and Fort Union Formations, Powder River Coal Field, Wyoming (from Glass and Jones, 1991). 
All but six analyses of the Wyodak coal bed (Table 4) were within the heating value category of 15-19.99 million Btu/short ton. However, each of those six analyses represent only part of the total coal bed thickness and is not typical of the entire coal bed. The six analyses probably do not represent significant areas of lower heating values within the Wyodak coal deposit.

The 19 billion tons of original strippable DRB of coal in the Wyodak bed consist of about 5.8 billion tons of coal with less than $0.40 \mathrm{lbs}$ sulfur/million Btu, about 9.3 billion tons of coal with 0.41-0.60 lbs sulfur/million Btu, and about 3.9 billion tons of coal with 0.61-0.83 lbs sulfur/million Btu. An additional 0.4 billion tons of new DRB for the Caballo Creek area (Grazis, 1977) was added to the original DRB and about 1.5 billion tons of coal depleted through mining and production losses was subtracted from the original DRB. With those adjustments, the remaining $\mathrm{DRB}$ for the Wyodak is now about 17.9 billion tons. Of this total, about 4.9 billion tons of coal is less than $0.40 \mathrm{lbs}$ sulfur/ million Btu, 9.2 billion tons of coal is from 0.41-0.60 lbs sulfur/million Btu, and 2.8 billion tons of coal is from 0.61-0.83 lbs sulfur/million Btu. All this is shown on Table 2.

5. Felix, Lower Ulm, Scott, C", C' and C coal beds. The C", C', and C coal beds occur above the Wyodak coal bed, and are overlain, in turn, by the Felix, Scott, and Lower Ulm coal beds (Figure 5). These Wasatch Formation beds all contain original strippable DRB of coal because none of them have been mined. As in the Wyodak deposit, strippable coal is that under 200 feet or less of cover. The DRB for these coal beds is restricted to the Caballo Creek area (Figures 2 and 3).

The Felix coal bed in the Caballo Creek area contains abcut 1.1 billion tons of DRB coal with a heating value of $15-19.99$ million Btu/short ton (Table 1). About 0.8 billion tons of the DRB coal contains 0.84-1.67 lbs sulfur/million Btu. The rest contains 0.61$0.83 \mathrm{lbs} /$ sulfur/million Btu.

Coal beds other than the Felix coal bed in the Caballo Creek area contain a combined total DRB of about 0.2 billion tons of coal. Most of these coals are higher in sulfur contents ( 0.84 to over $2.50 \mathrm{lbs}$ sulfur/million Btu). The Scott and part of the C" coal beds contain some coal reserves having heating contents of less than 15 million Btu/short ton; the remainder of the DRB for these beds occurs in the 15-19.99 million Btu/short ton category. Table 1 shows a breakdown of the DRB for all these coal beds. 


\section{REFERENCES CITED}

Glass, G.B., and Jones, R.W., 1991, Coal fields and coal beds of Wyoming: Wyoming Geological Association 42nd Field Conference Guidebook, p. 133-167.

Grazis, S.L., 1977, Geologic map and coal resources of the Scaper Reservoir Quadrangle, Campbell County, Wyoming: U.S. Geological Survey Coal Investigations Map C-77, scale $1: 24,000,3$ sheets.

Smith, J.B., Ayler, M.F., Knox, C.C., and Pollard, B.C., 1972, Strippable coal reserves in Wyoming: U.S. Bureau of Mines Information Circular 8538, 51 p. 
APPENDIX C. DEMONSTRATED RESERVE BASE OF STRIPPABLE COAL IN THE CANYON, DRY CHEYENNE, LAKE DE SMET/HEALY, ACME-KLEENBURN, SPOTTED HORSE, SUSSEX, AND WYARNO-VERONA DEPOSITS, POWDER RIVER COAL FIELD, WYOMING. 


\section{List of Tables}

Table 1. Summary of remaining demonstrated reserve base (DRB) of the Canyon, Dry Cheyenne, Lake De Smet/Healy, Acme-Kleenburn, Spotted Horse, Sussex, and Wyarno-Verona deposits, Powder River Coal Field, Wyoming, through December 31, 1990 (in million short tons)

Table 2. In-place and remaining DRB for the Acme-Kleenburn deposit in

Table 3. Sulfur and heating values for the Canyon (Clear Creek) deposit

Table 4. Sulfur and heating values for the Dry Cheyenne deposit

Table 5. Sulfur and heating values for the Lake De Smet deposit

Table 6. Sulfur and heating values for the Spotted Horse deposit

Table 7. Sulfur and heating values for the Sussex deposit

Table 8. Sulfur and heating values for the Wyarno-Verona deposit C-12

\section{List of Figures}

Figure 1. Correlation of coal beds in the Wasatch and Fort Union

Formations, Powder River Coal Field, Wyoming (from Glass and Jones, 1991) ...... C-15

Figure 2. Canyon deposit, Spotted Horse area (based on Plate 1,

U.S. Geological Survey Bulletin 1050) (after Smith and others, 1972)

Figure 3. Dry Cheyenne deposit, Glenrock area (based on Plate 4,

U.S. Geological Survey Bulletin 806A) (after Smith and others, 1972)

Figure 4. Healy deposit (from Smith and others, 1972)

Figure 5. Acme-Kleenburn deposit, Sheridan area (based on U.S.

Geological Survey and company data) (after Smith and others, 1972)

Figure 6. Felix deposit, Spotted Horse area (based on Plate 2,

U.S. Geological Survey Bulletin 1050) (after Smith and others, 1972)

Figure 7. Smith-Local deposit, Spotted Horse area (based on Plate 2,

U.S. Geological Survey Bulletin 1050) (after Smith and others, 1972)

Figure 8. Location of Sussex deposit (modified from Figure 4 of Glass, 1976)

Figure 9. The Wyarno-Verona deposit

(modified from Figure 5 of Culbertson and Mapel, 1976) 
1. Summary. The remaining demonstrated reserve base (DRB) of strippable coal in the above seven deposits totals 4.4 billion short tons (Table 1). Coals in these deposits occur in the Paleocene Fort Union Formation and the Eocene Wasatch Formation. Of the total DRB in these seven deposits, the Wyarno-Verona deposit contains about 1.8 billion tons ( $40 \%$ ), the Spotted Horse deposit contains just over 1 billion tons (27 percent), and the Lake De Smet/Healy deposit contains 1 billion tons (22 percent).

Of the 4.4 billion tons of coal in the DRB, about 1.5 billion tons ( 33 percent) have a heating value of $15.00-19.99$ million Btu/short ton. Coal beds in this heating value category include the F bed in the Dry Cheyenne deposit, the Monarch and Dietz \#3 beds in the Acme-Kleenburn deposit, the Felix and Smith beds in the Spotted Horse deposit, Fort Union Formation beds in the Sussex deposit, and the PK bed in the Wyarno-Verona deposit. The remaining 3.0 billion tons ( 64 percent) contain less than 15.00 million Btu/ short ton.

The 4.4 billion tons of strippable coal in the DRB occur in five different sulfur categories. About 45 percent (2.0 billion tons) of the coal occurs in the 0.84-1.67 lbs sulfur/million Btu category. This includes 0.2 billion tons in the Canyon coal deposit, 0.8 billion tons in the Lake De Smet/Healy deposit, and 1.0 billion tons in the Spotted Horse deposit. Only 0.4 billion tons (ten percent) of the coal is found in the three sulfur catego ies of less than $0.84 \mathrm{lbs}$ sulfur/million Btu. The 0.4 billion tons of coal in these three lower sulfur categories are all from coal beds in the Fort Union Formation.

About 1.8 billion tons (about 40 percent) of the $\mathrm{DRB}$ in these seven deposits contain more than $2.50 \mathrm{lbs}$ sulfur/million Btu. About 0.2 billion tons (about 5 percent) of the DRB in these seven deposits contain $1.68-2.50 \mathrm{lbs}$ sulfur/million Btu. Coals in these two highest sulfur categories all occur in the Wasatch Formation.

2. Methodology and Assumptions. Original strippable DRB tonnages were taken from published sources including Smith and others (1972), Culbertson and Mapel (1976), and Glass (1981). Only the Acme-Kleenburn deposit required a tonnage adjustment due to mining and production losses. Although some production did occur in several other deposits, the tonnage was not significant and did not affect the DRB. The adjustment for the Acme-Kleenburn deposit, as shown in Table 2, used an 83 percent recovery factor, a calculated figure based on Glass (1981) for Big Horn Coal Company. 
Table 1. Summary of Remaining Demonstrated Reserve Base (DRB) of the Canyon, Dry Cheyenne, Lake De SmetHealy, Acme-Kleenburn, Spotted Horse, Sussex, and Wyarno-Verona coal deposits, Powder River Coal Fleld, Wyoming, through December 31, 1990 (in million short tons).

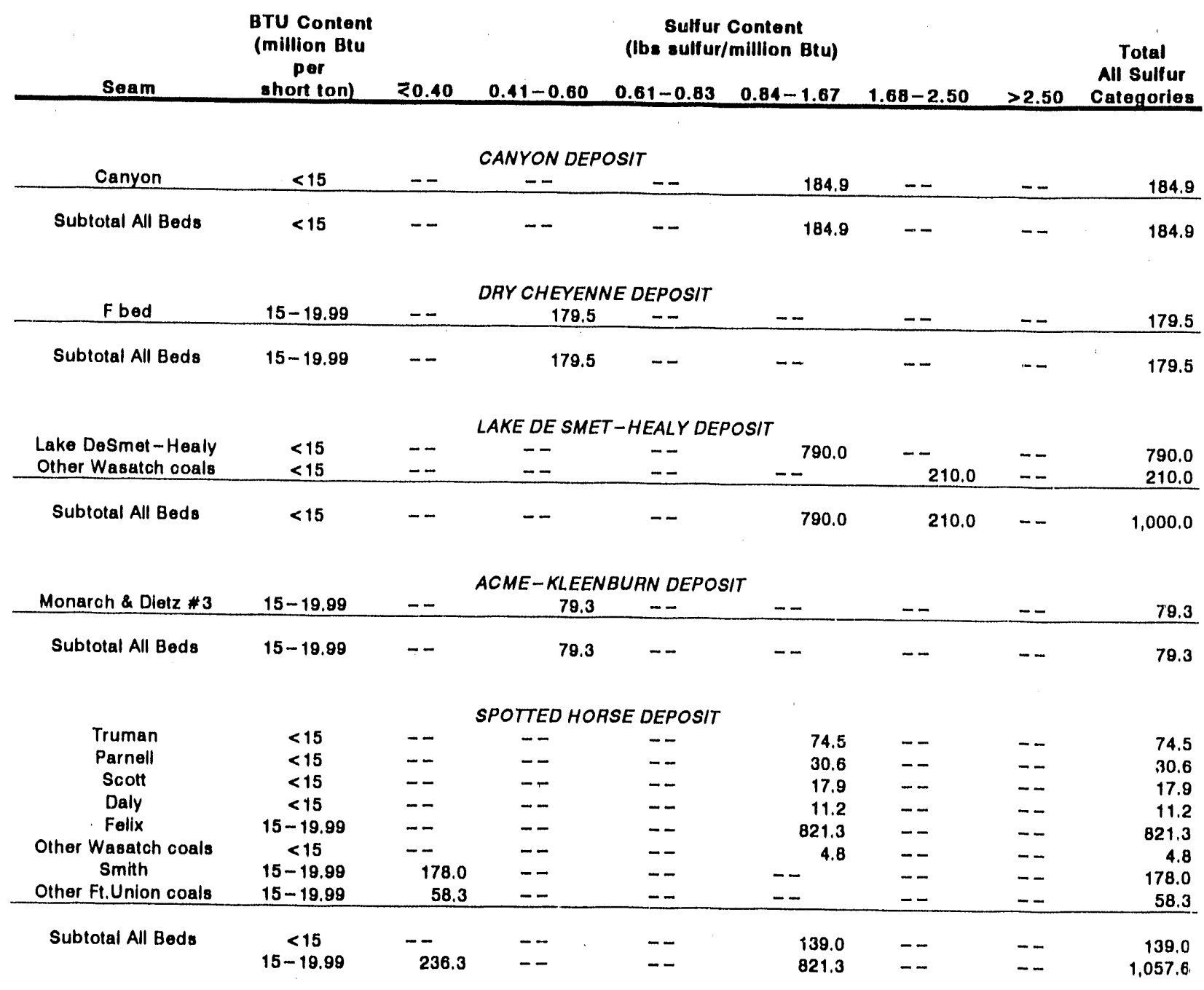

\begin{tabular}{|c|c|c|c|c|c|c|c|c|}
\hline & & & SEX & & & & & \\
\hline Fort Union Fm. coals & $15-19.99$ & -- & -- & -- & 13.6 & -- & -- & 13.15 \\
\hline Subtotal All Beds & $15-19.99$ & -- & -- & -- & 13.6 & -- & -- & 13.6 \\
\hline
\end{tabular}

\begin{tabular}{|c|c|c|c|c|c|c|c|c|}
\hline \multicolumn{9}{|c|}{ WYARNO-VERONA DEPOSIT } \\
\hline PK & $15-19.99$ & -- & -- & -- & -- & -- & 200.0 & 200.0 \\
\hline Uim 2 (lower) & $<15$ & -- & -- & -- & -- & -- & 990.0 & 990,0 \\
\hline Uim 1 (upper) & $<15$ & -- & -- & -- & -- & -- & 543.0 & 543.0 \\
\hline Other Wasatch coals & $<15$ & - & -- & - & -- & -- & 67.0 & 67.0 \\
\hline Subtotal All Beds & $\begin{array}{l}<15 \\
15-1009\end{array}$ & -- & -- & -- & -- & -- & $1,600.0$ & $1,600.0$ \\
\hline & $15-19.99$ & -- & -- & -- & -- & -- & 200.0 & 200.0 \\
\hline
\end{tabular}

TOTAL ALL DEPOSITS

\begin{tabular}{|c|c|c|c|c|c|c|c|c|}
\hline Total All Coal Beds & $\begin{array}{c}<15 \\
15-18.88 \\
\end{array}$ & $-\overline{2}$ & 256.6 & -- & $\begin{array}{r}1,113.9 \\
034.9 \\
\end{array}$ & $--^{210.0}$ & $\begin{array}{r}1,600,0 \\
200,0 \\
\end{array}$ & $\begin{array}{l}2,923.9 \\
1,530,0 \\
\end{array}$ \\
\hline Total All Btu Categories & & 236.3 & 258.8 & -- & $1,948.8$ & 210.0 & $1,800.0$ & $4,4533.9$ \\
\hline
\end{tabular}


Table 2. In-place and remaining DRB for the Acme-Kleenburn Deposit in the western part of the Powder River Coal Fleld (in million short tons). Numbers in parentheses are negative.

\begin{tabular}{|c|c|c|c|c|c|c|c|c|c|}
\hline & & $\begin{array}{l}\text { Btu Content } \\
\text { (milllon Btu/ }\end{array}$ & & & $\begin{array}{r}\text { Sulfu } \\
\text { (Ibs sulfi }\end{array}$ & $\begin{array}{l}\text { Content } \\
\text { /million Btu) }\end{array}$ & & & $\begin{array}{c}\text { Total } \\
\text { All Sulfur }\end{array}$ \\
\hline & & short ton) & 50.40 & $0.41-0.60$ & $0.61-0.83$ & $0.84-1.67$ & $1.68-2.50$ & $>2.50$ & Categories \\
\hline A. & $\begin{array}{l}\text { Original strippable DRB } \\
\text { modiffed from Smith et al, } \\
\text { 1972. Revised to Jan. 1, }\end{array}$ & & & & & & & & \\
\hline & 1969 by Glass, 1981 & $15-19.99$ & - & 125.0 & - & - & - & - & 125.0 \\
\hline & $\begin{array}{l}\text { Coal production } 1969 \\
\text { through } 1990\end{array}$ & $15-19.99$ & - & $(37.9)$ & - & - & - & - & $(37,9)$ \\
\hline & $\begin{array}{l}\text { Mining losses (83\% } \\
\text { recovery) }\end{array}$ & $15-19.99$ & - & (7.8) & - & - & - & - & $(7.8)$ \\
\hline D. & Total coal depleted $(B+C)$ & $15-19.99$ & - & $(45.7)$ & - & - & - & - & $(45.7$ \\
\hline & $\begin{array}{l}\text { Remaining strippable } \\
\text { DRB through } 12 / 31 / 90 \\
(A+D)\end{array}$ & - & - & 79.3 & - & - & - & - & \\
\hline
\end{tabular}

This recovery factor means that 83 percent of the total coal in-place was recovered, and that the remaining 17 percent of the coal in-place was not recovered because of mining losses and other inefficiencies.

In all seven deposits, sulfur contents and heating values were assigned to each coal bed or group of coal beds by determining either averages or weighted averages for each area underlain by strippable DRB. Where little or no data was found within the DRB, analyses of similar coals from nearby areas were used in characterizing the deposits.

3. Analyses. Coal analyses used in this report were taken from various published and unpublished sources (Tables 3 through 8 ). Whenever possible, analyses from within a coal deposit were used to assign coal quality categories to the DRB. Analyses of nearby coal beds, however, were used to characterize the F bed in the Dry Cheyenne deposit and the Parnell and Daly beds in the Spotted Horse deposit. Analyses from more than 1,000 core, channel, tipple, and delivered coal samples were examined for these strippable deposits.

All analyses were evaluated on an individual basis. Analyses from uncorrelated coal beds or poorly located data points were not used. Where only partial thicknesses of a coal bed were sampled and analyzed and no other information was available noarby, the data were not considered representative of the entire coal bed and were not used in this study. Where only partial thicknesses of a coal bed were sampled and analyzed and 


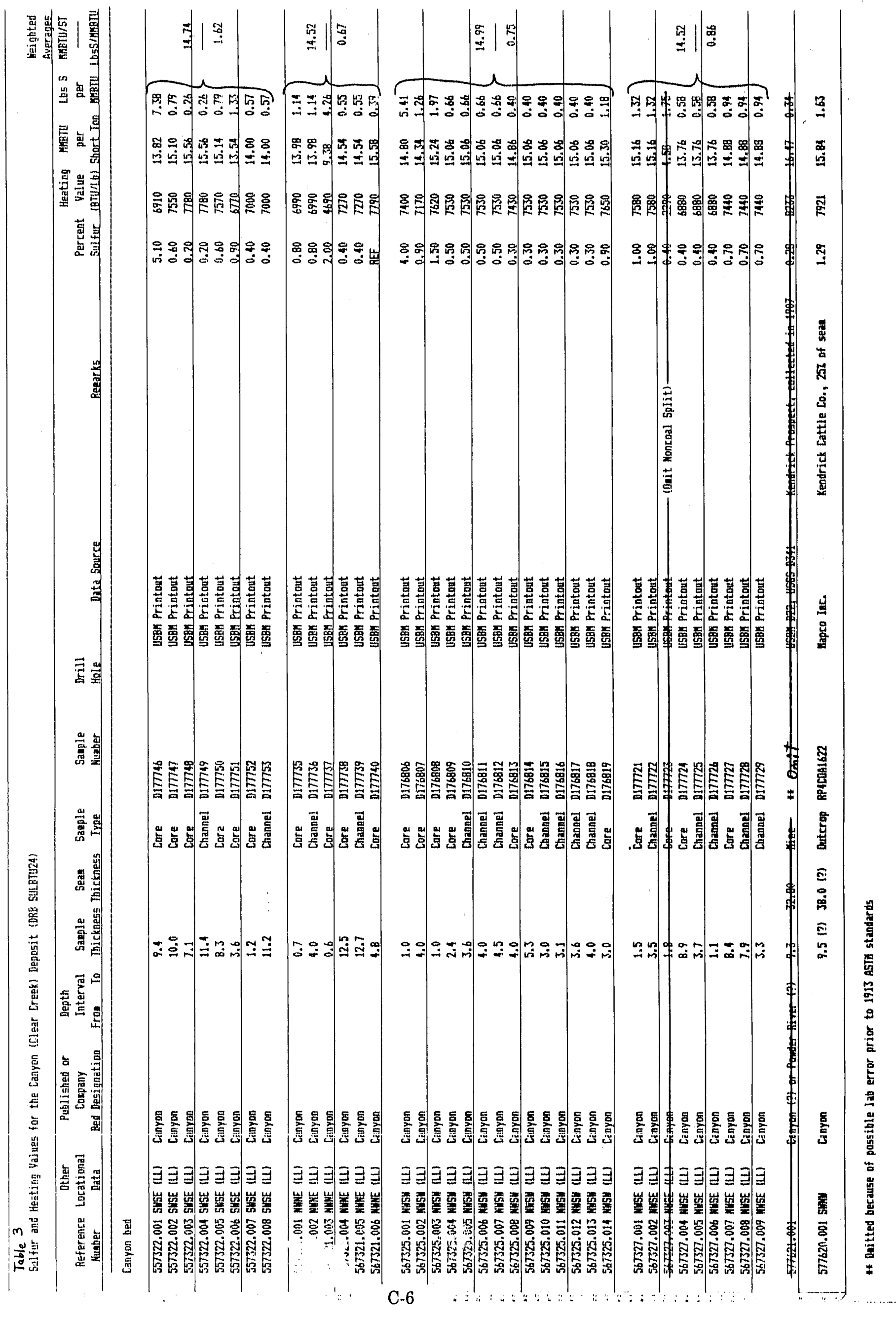




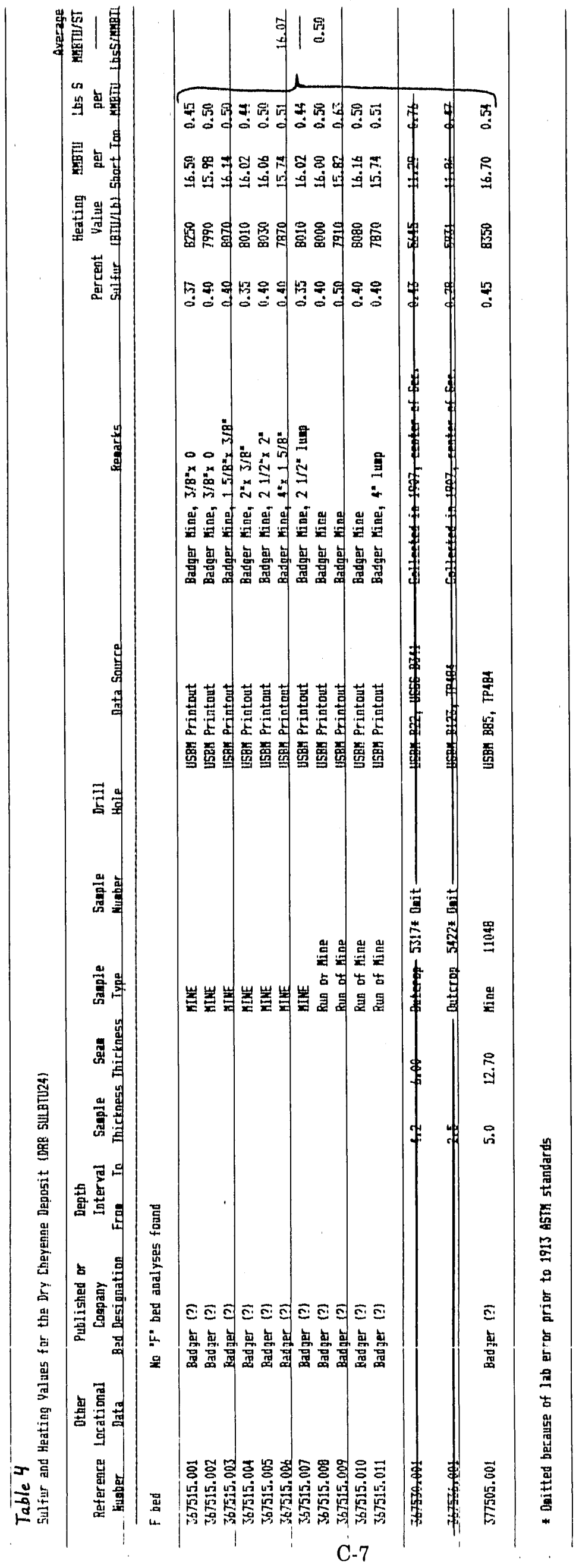




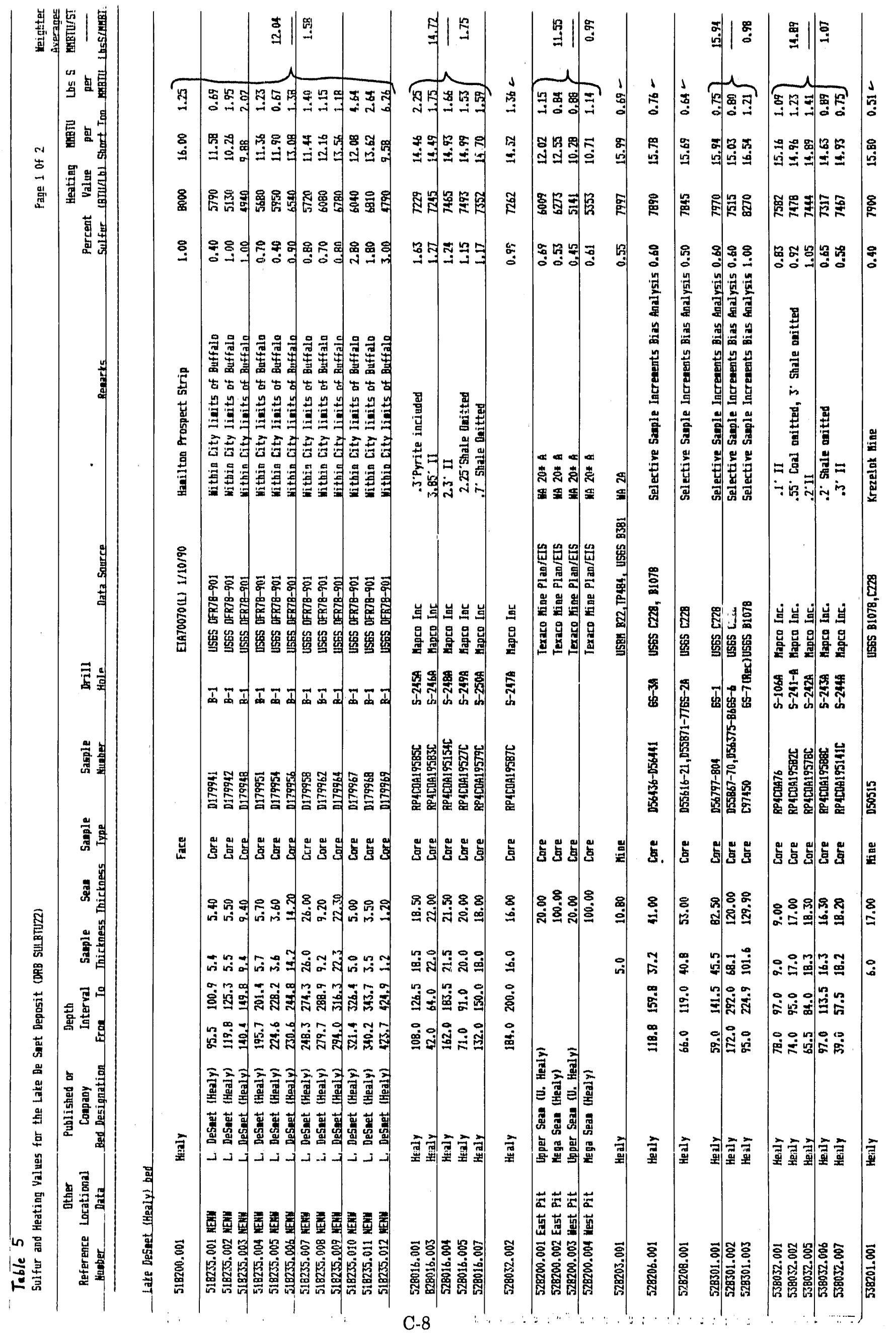




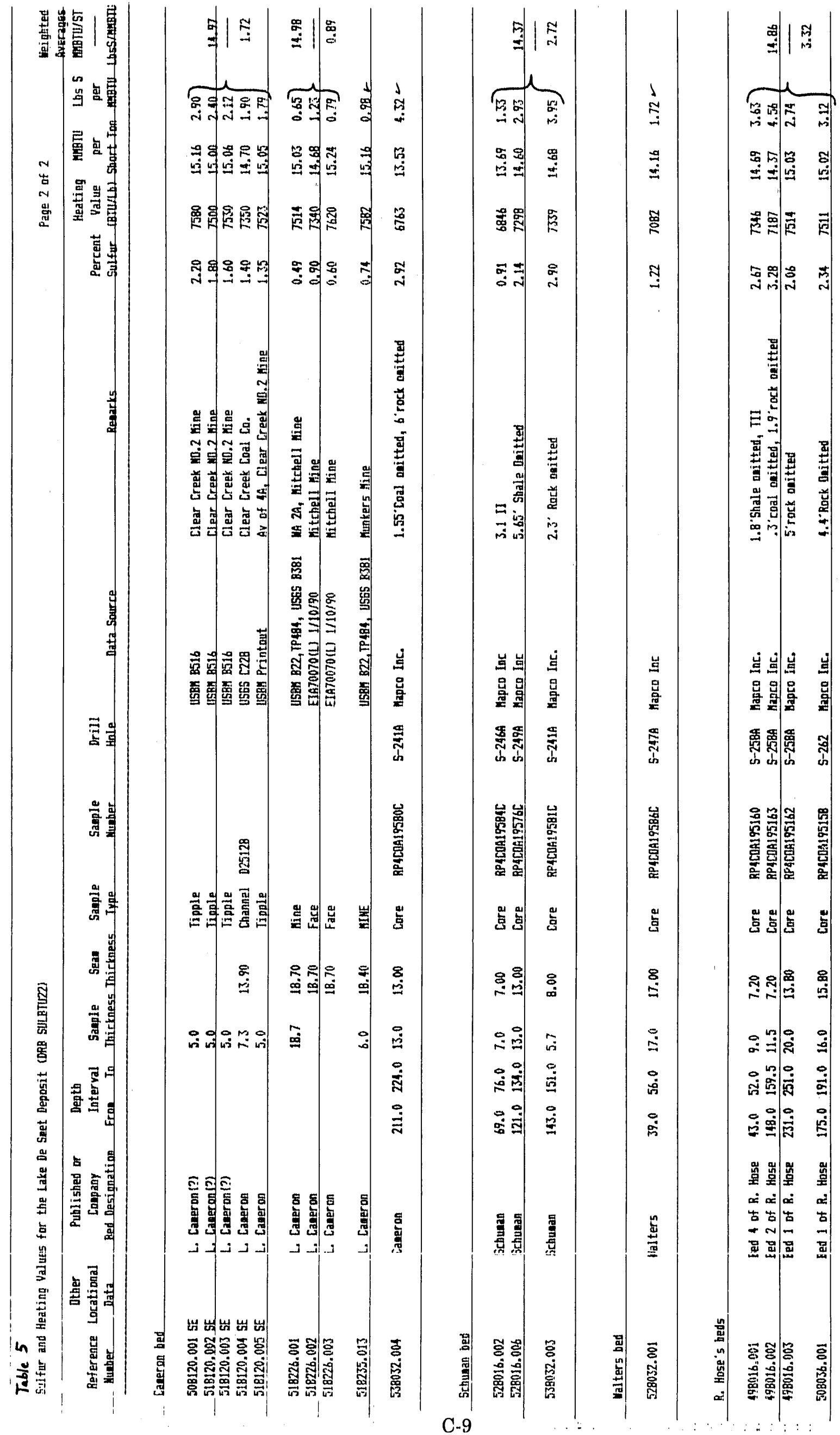




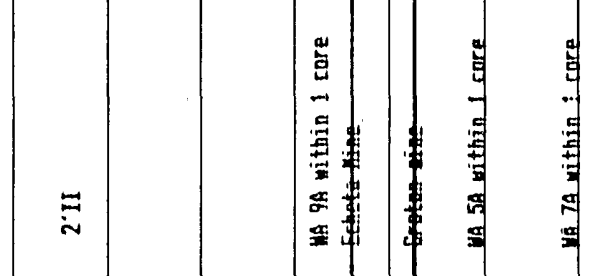

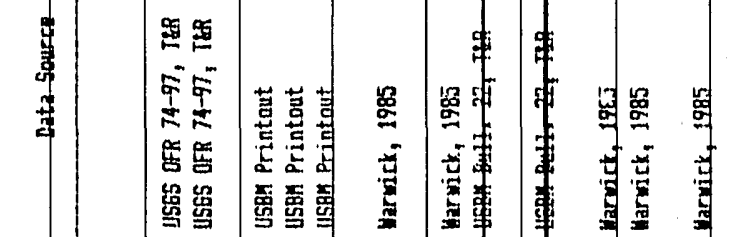

臣量 管员

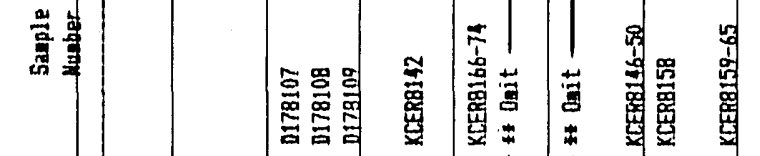

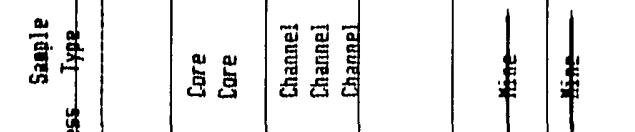

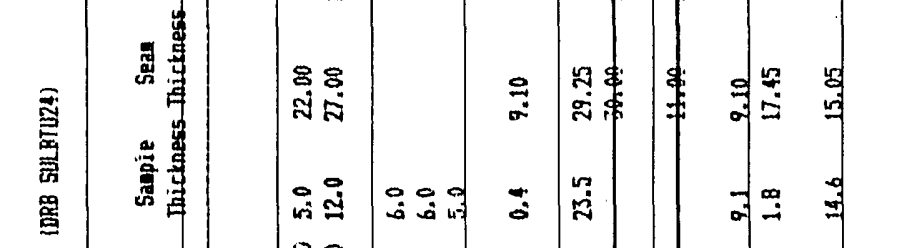

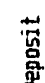

.

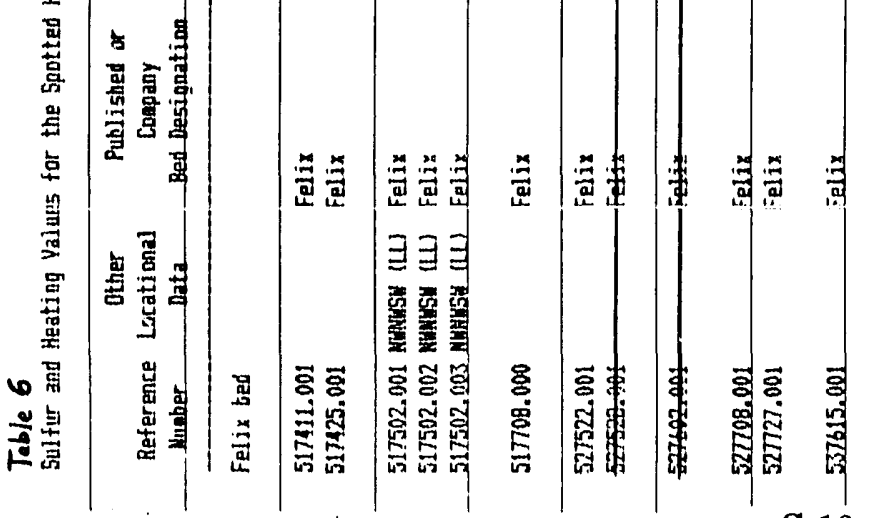

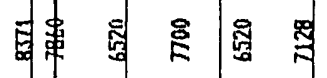

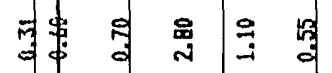

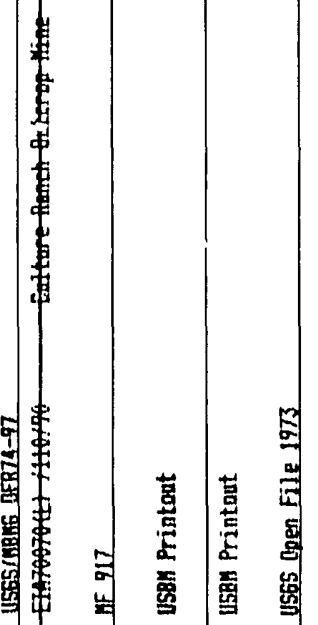

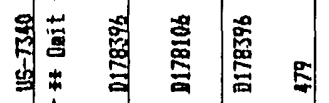

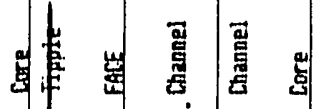

จ

: :

한

ฆ

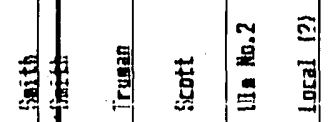

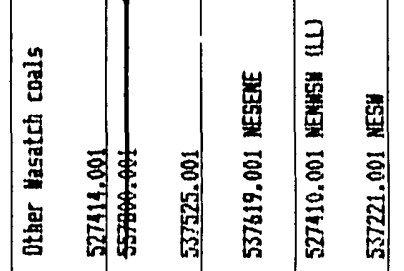




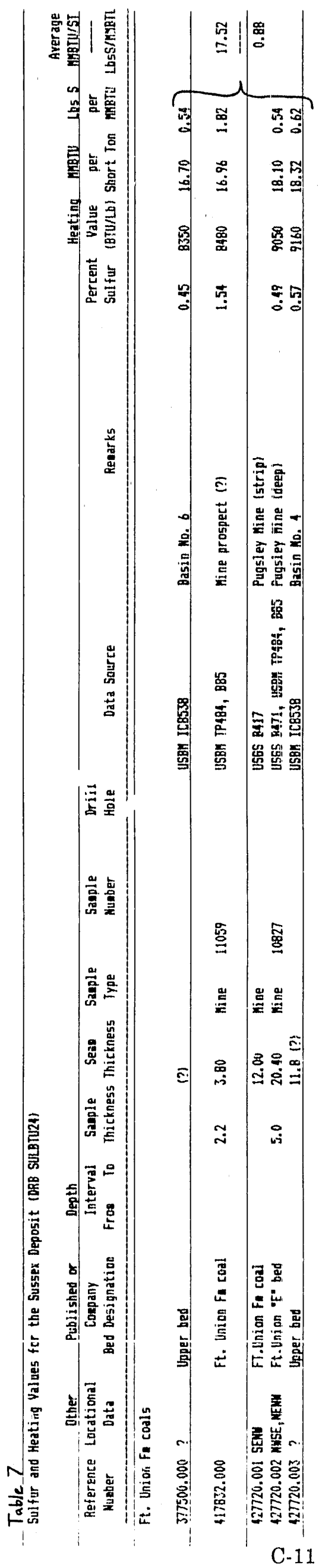




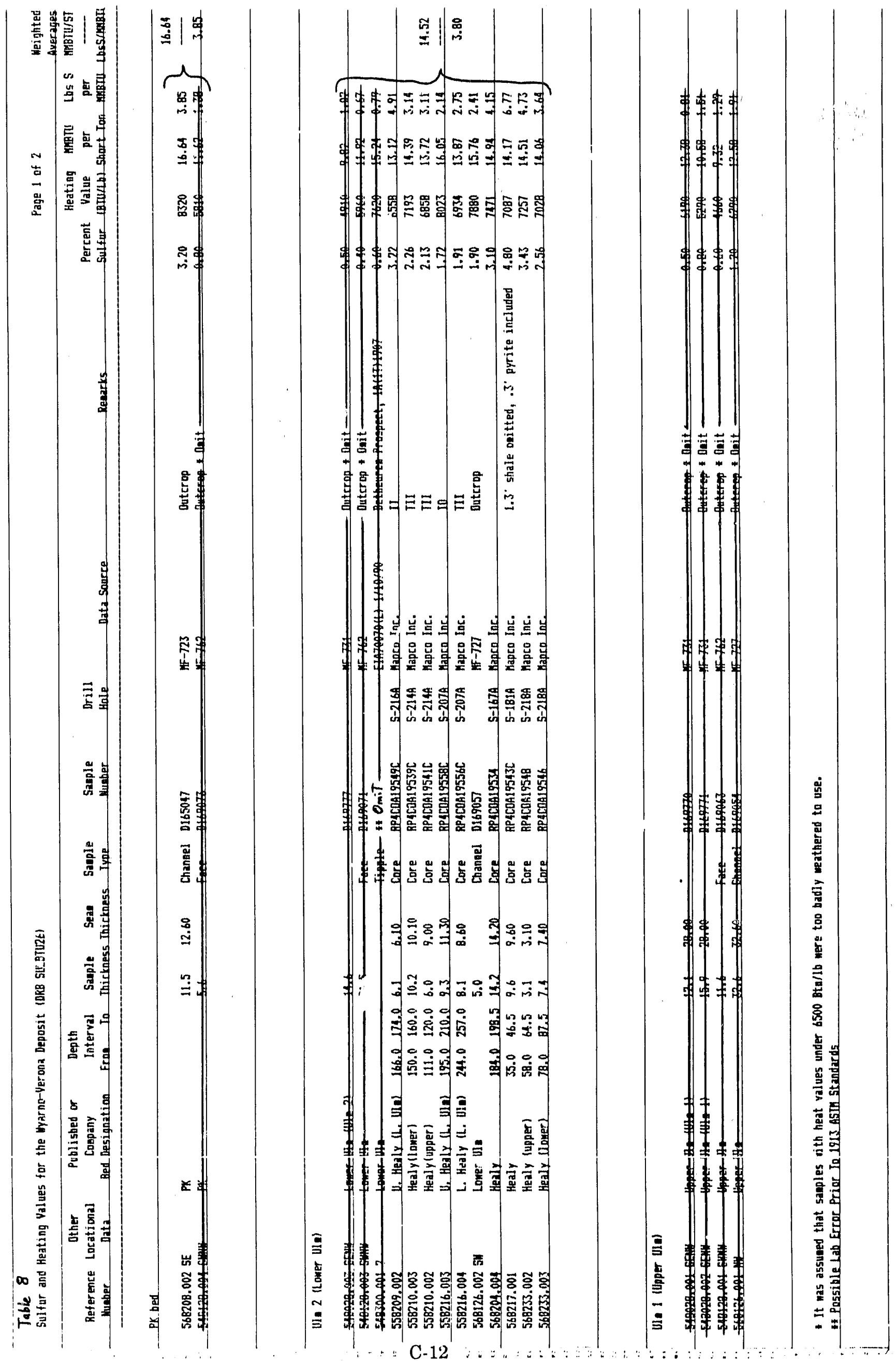




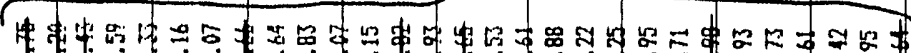

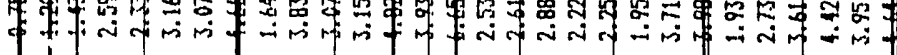

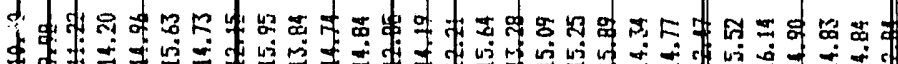

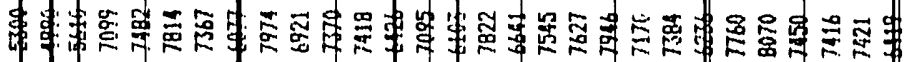

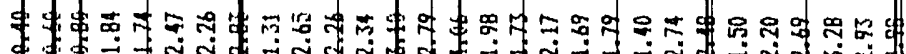

㟧

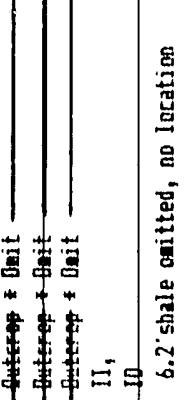

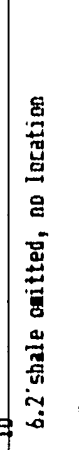

竞

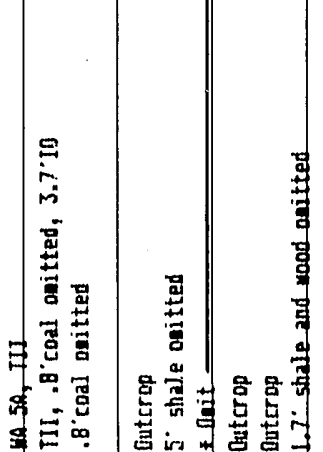

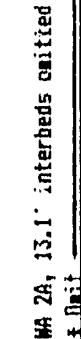

革

志央

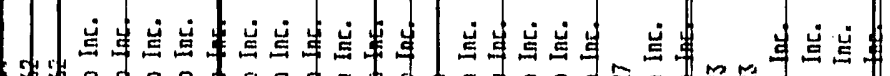

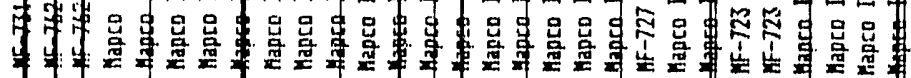

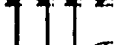

害齿

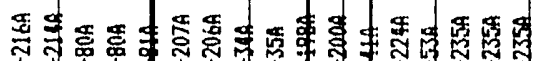

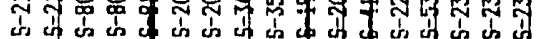

空㧝

兽燰突事

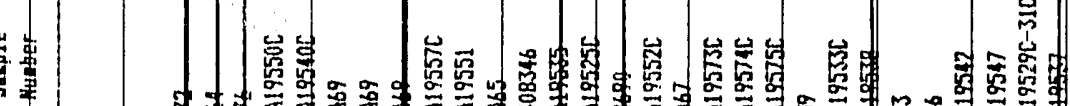

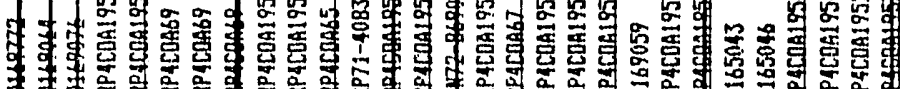

竞娄

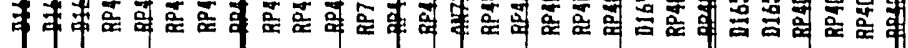

s.

爱

空

竞竞

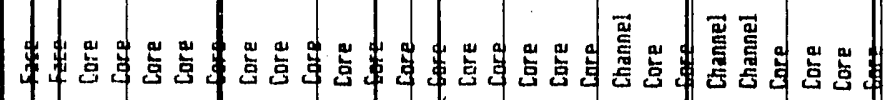

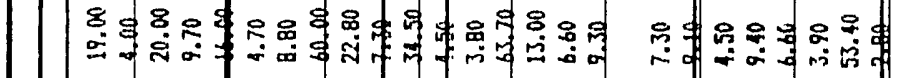

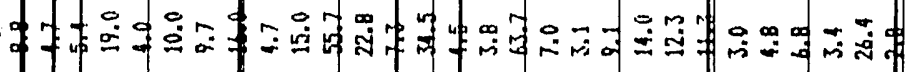

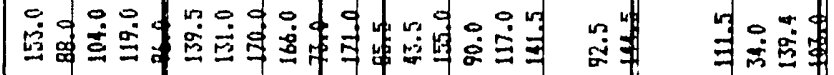

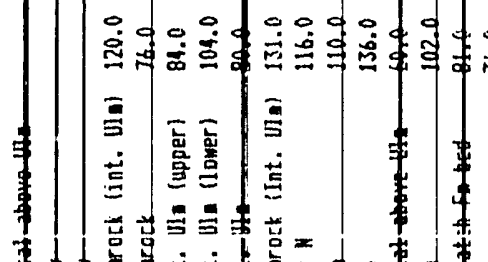

요영

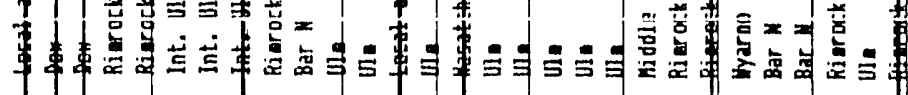


there was other information on coal thickness añ quality (of complete coal beds) available nearby, the analyses were weighted by linear footage sampled.

4. Canyon Deposit. The Canyon coal bed occurs in the Fort Union Formation in the northern part of the Powder River Coal Field, Wyoming (Figure 1). It averages 11 feet thick in this area; strippable coal is under 120 feet or less of cover. The strippable DRB for the Canyon coal deposit defined by Smith and others (1972) contains 184.9 million tons of strippable coal (Figure 2). Only two analyses are known for the Canyon coal bed in this area. One analysis represents only 25 percent of the seam; the other analysis is of questionable value (see note on Table 3). Analyses from a nearby area southeast of the Canyon deposit were used to calculate the heat value and sulfur content for this deposit.

5. Dry Cheyenne Deposit. The Dry Cheyenne deposit (Figure 3) contairıs 179.5 million tons of strippable coal in the F bed of the Wasatch Formation. (Smith and others, 1972). This bed has not been correlated with any others in the coal field. The average thickness of this coal bed is 7.5 feet and strippable coal occurs under 120 fect or less of cover. Since no analyses exist for the $\mathrm{F}$ bed, average analyses from the nearby Badger bed in the Glenrock/Dave Johnston coal deposit were used to characterize the Dry Cheyenne deposit (Table 4).

6. Lake De Smet/Healy Deposit. All coal beds in this deposit occur in the Eocene Wasatch Formation. As many as five coal beds, including the Ucross, Murray, Cameron, Healy, and Walters beds coalesce to form the thick Lake De Smet coal bed (Figure 1), which exceeds 250 feet in thickness near Take De Smet (Glass and Jones, 1991). Although total resources for the area were calculated for coal beds at depths of up to 1,000 feet (Mapel, 1959), strippabie coal resources are calculated to an overburden depth of only 200 feet (Smith, and others, 1972). Coal resources for the thickest two coal beds in the area, the Lake De Smet and Healy, are combined. Resources for the other coal beds in the area, including the Monument Peak, Walters, Upper and Lower Cameron, Murray, Ucross, and several unnamed local coal beds are also combined (as "other Wasatch" coal beds). None of the coal beds in this deposit are currently mined.

The Lake De Smet/Healy deposit (Figure 4) contains 1 billion tons of strippable coal in the Lake De Smet/Healy coal bed(s) and in other Wasatch coal beds (Smith and others, 1972). Mapel (1959) listed measured and indicated reserves for coal beds greater than 


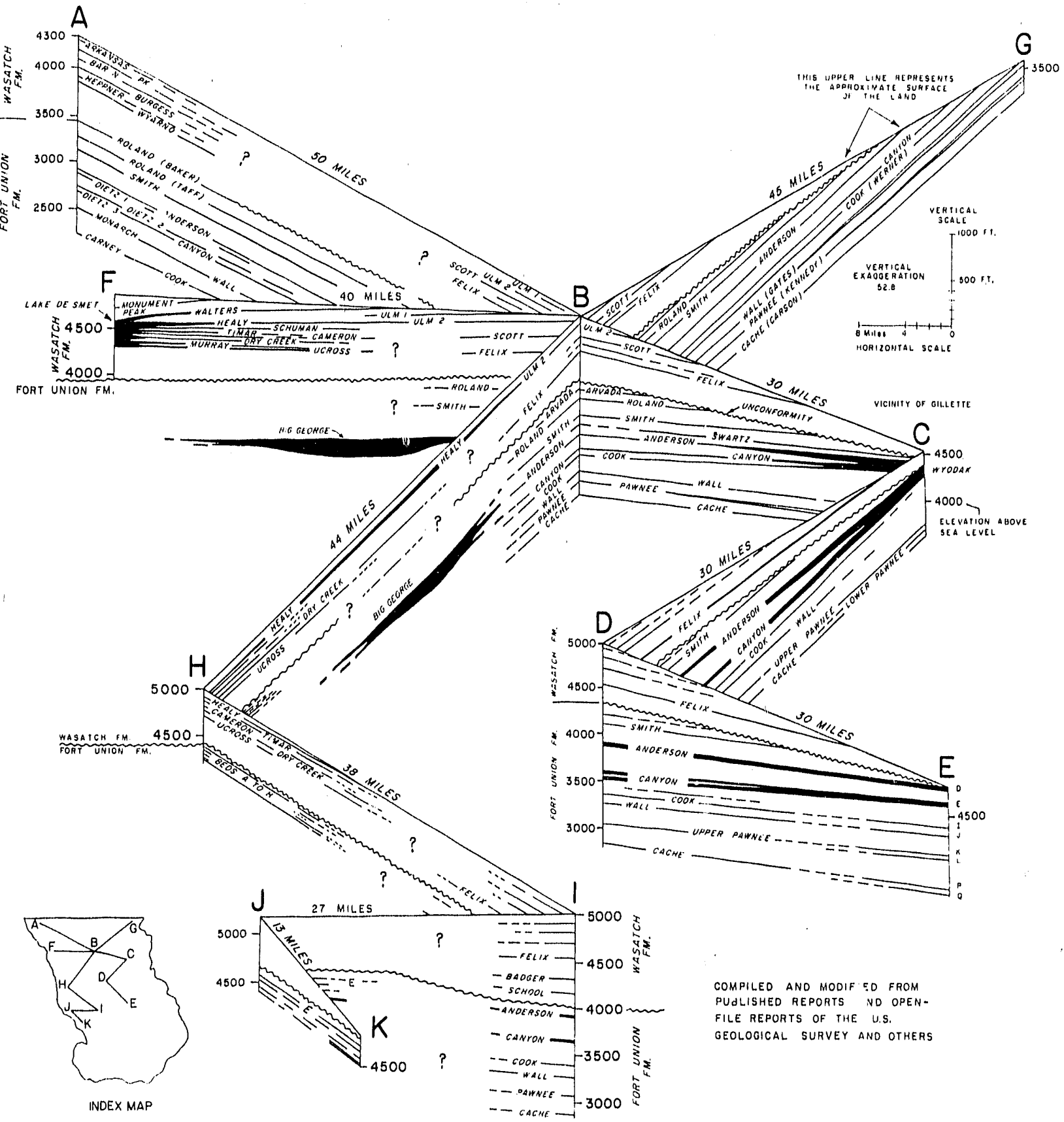

Figure 1. Correlation of coal beds in the Wasatch and Fort Union Formations, Powder River Coal Field, Wyoming (from Glass and Jones, 1991). 


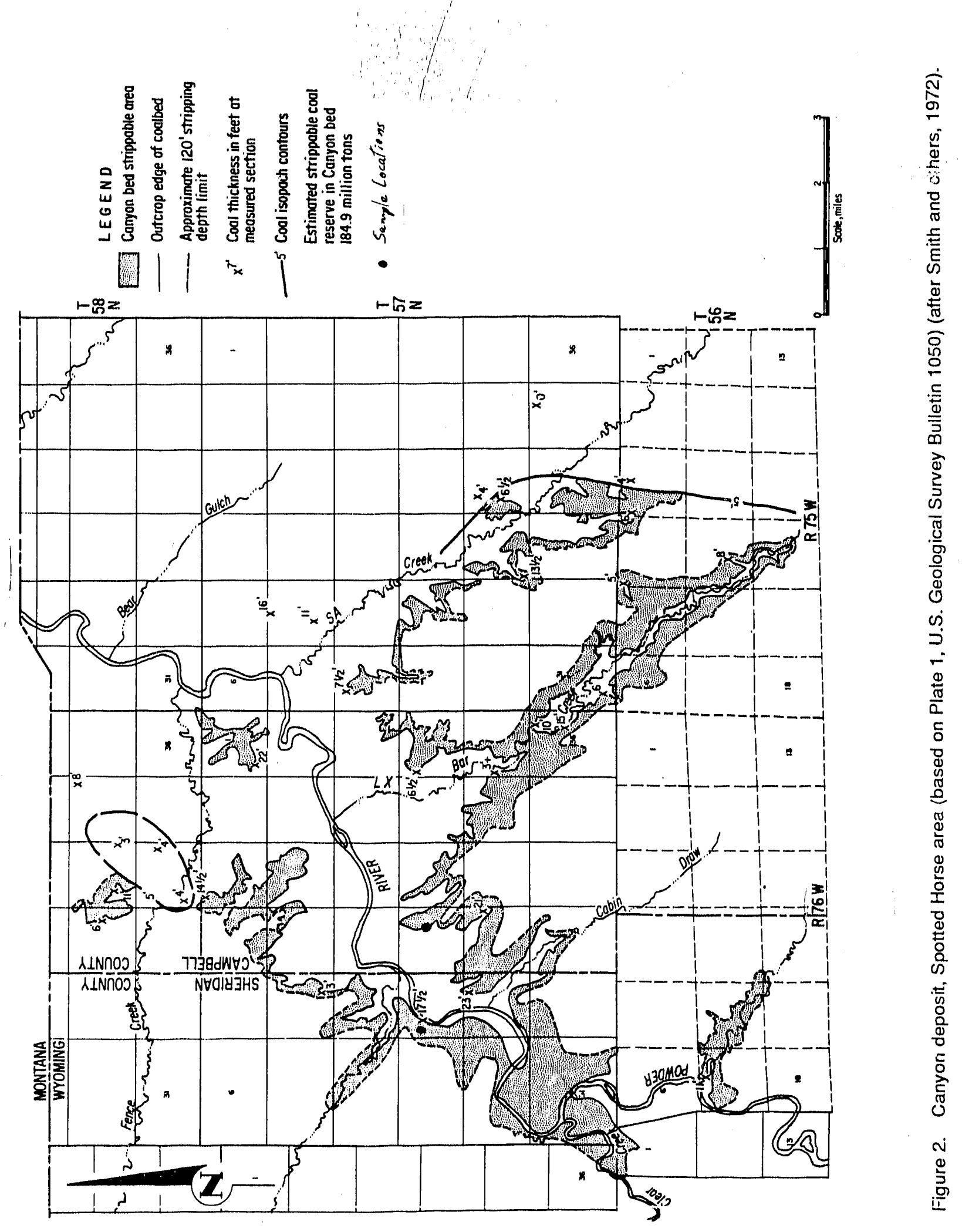




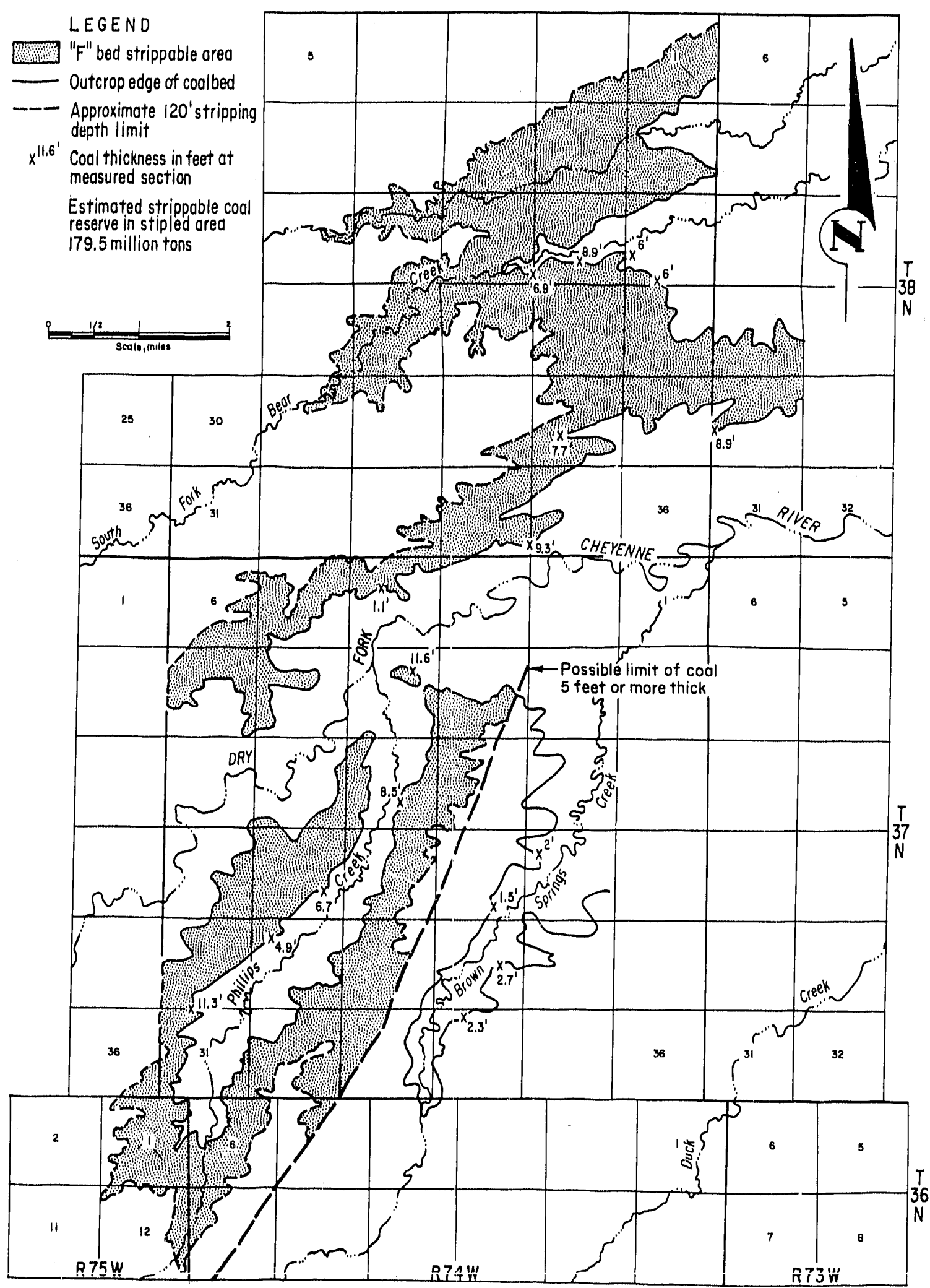

Figure 3. Dry Cheyenne deposit, Glenrock area (based on Plate 4, U.S. Geological Survey Bulletin 806A) (after Smith and others, 1972). 

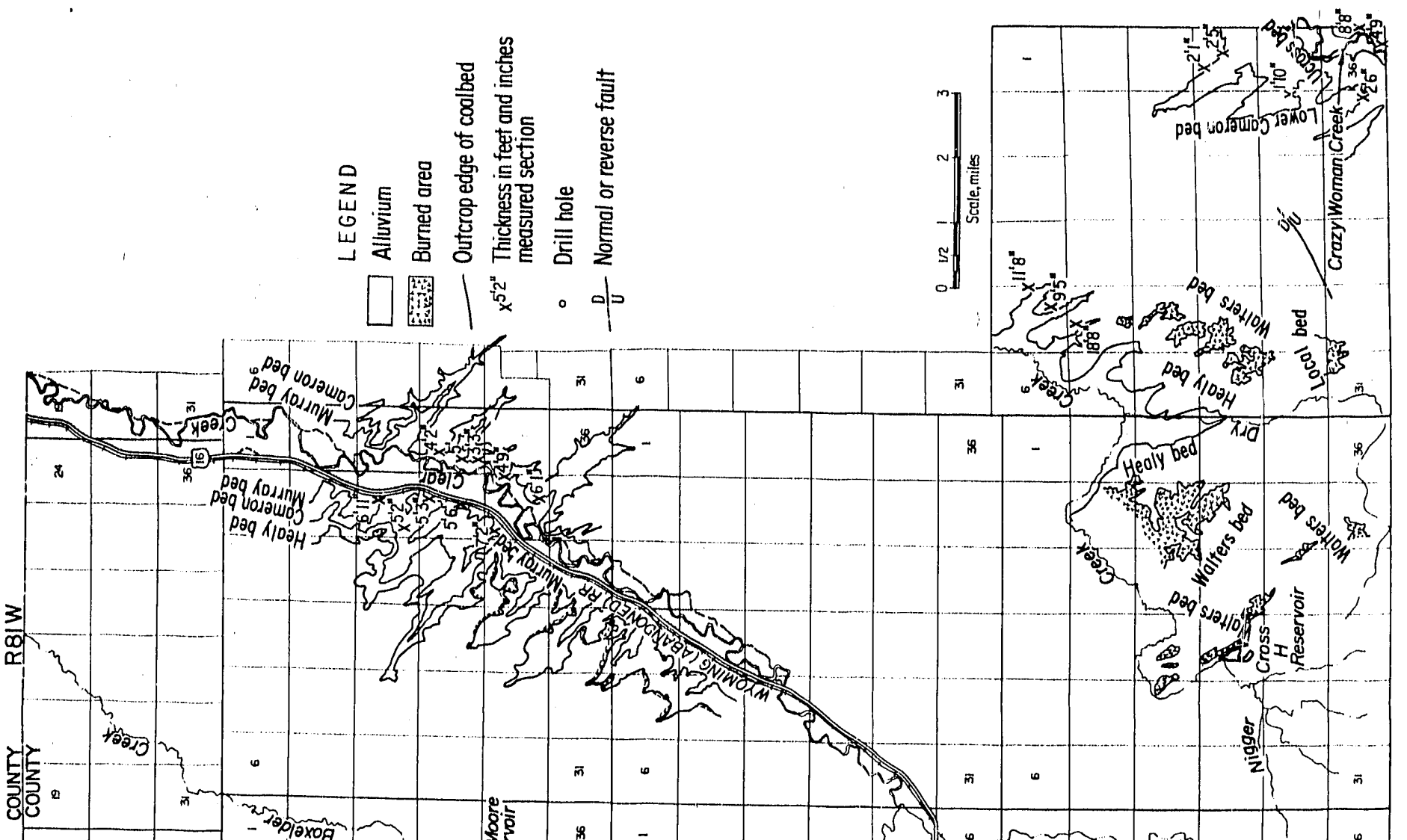

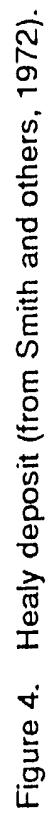

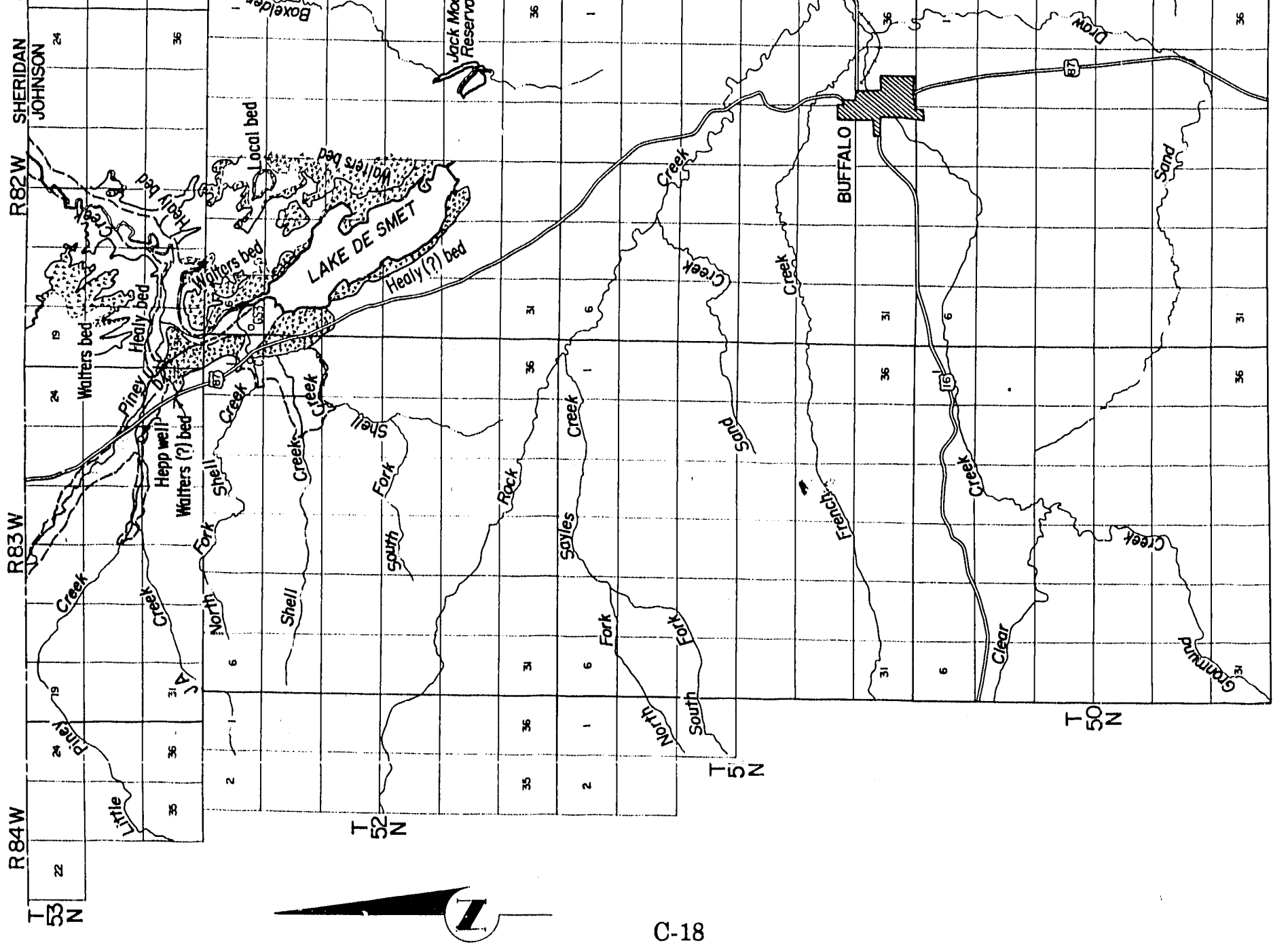


5 feet thick: approximately 79 percent of the reserves occur in the Lake De Smet/Healy coals; the remainder of the reserves occur in other Wasatch coals. These percentages were applied to the strippable DRB, with 790 million tons assigned to the Lake De Smet/ Healy bed and 210 million tons assigned to th 3 other Wasatch coal beds (Table 5).

7. Acme-Kleenburn Deposit. Strippable coal beds from the Fort Union Formation in this deposit include the Carney, Masters, Monarch, Dietz 1, 2, and 3, Smith, and Roland (Figure 1). Although overburden limits for strippable coal in this deposit have not been published, any single coal bed under less than 200 feet of cover is probably strippable. The original DRB for the Acme-Kleenburn deposit from Smith and others (1.972) was revised upward by Glass (1985) to 125.0 million tons. The original DRB of Glass (1985) included strippable coal in just the Monarch and the Dietz No. 3 coal beds. Production and mining losses at Big Horn Coal Company's mine through December 31, 1990 leaves 79.3 million tons of remaining strippable DRB (see Table 2).

Since all the identified remaining DRB occurs within the Big Horn Coal Company property (Figure 5), coal quality for this remaining DRB is based on 36 analyses of delivered coal from that mine between January, 1986 and December, 1988. Weighted average values for these deliveries indicate that the remaining strippable DRB for the Monarch and Dietz \#3 coal beds averages 18.75 million Btu/short ton and $0.50 \mathrm{lbs}$ sulfur/ million Btu.

8. Spotted Horse Deposit. This deposit contains strippable coal in the Smith and related coal beds of the Fort Union Formation; the Felix bed and a local bed below the Felix in the Wasatch Formation; and four additional beds in the Wasatch Formation above the Felix, including the Daly, Scott, Parnell, and Truman coal beds (see Figure 1 for approximate stratigraphic positions of some of these coal beds). Strippable coal in the Smith and local beds ranges in thickness from 5 to 13 ieet and is less than 120 feet below the surface. The Felix coal bed averages 12.5 feet in thickness and is strippable where the overburden is less than 120 feet thick. Other strippable coal beds in the Wasatch Formation are locally 5 to 10 feet thick (Glass and Jones, 1991) and are less than 120 feet below the surface.

The Spotted Horse deposit contains 1,196.6 million tons of DRB coal (Class, 1985). Part of the Felix coal resource area plus the Smith and local coal beds are shown in Figures 6 and 7, respectively. The additional resources reported by Glass (1985) for the 


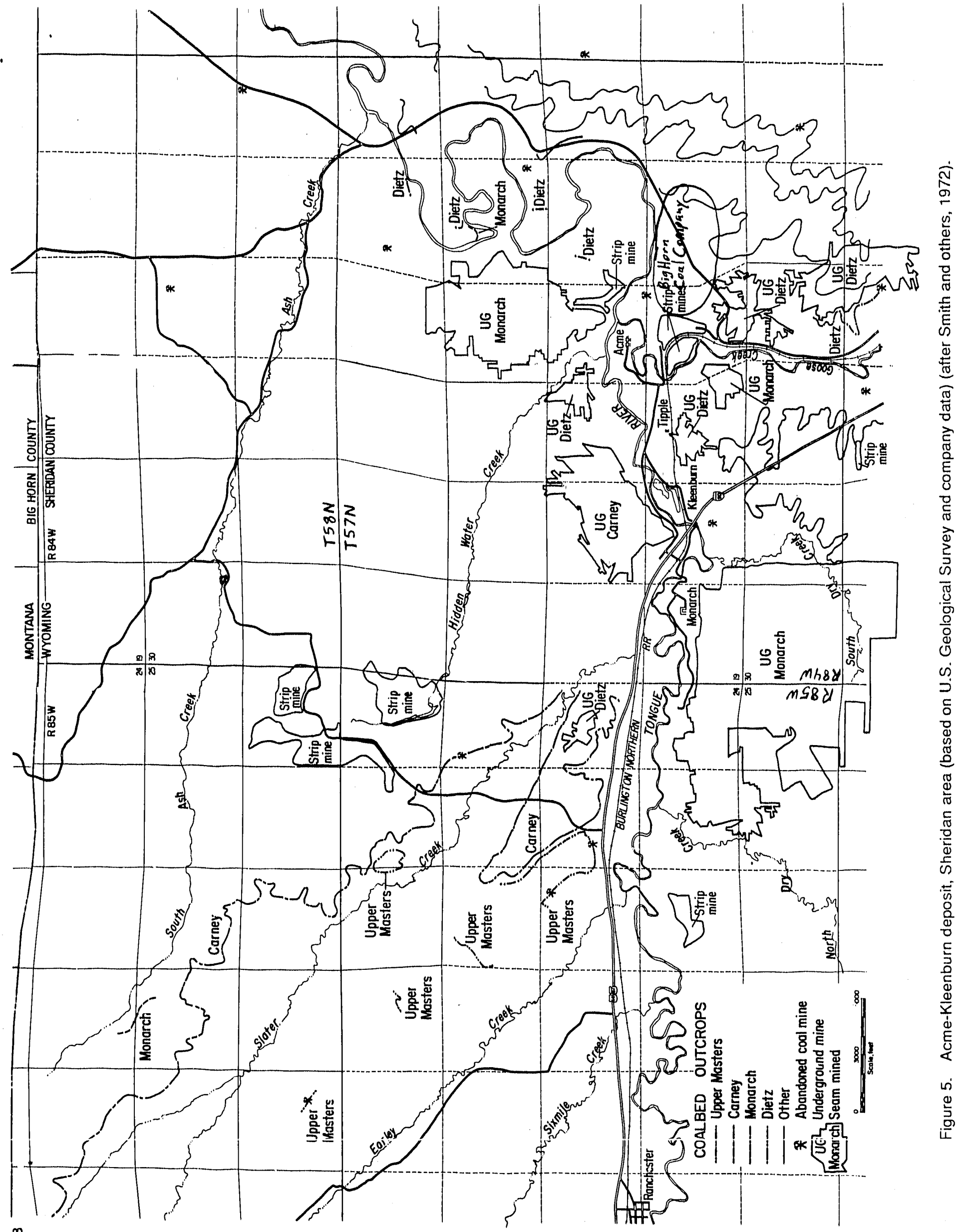




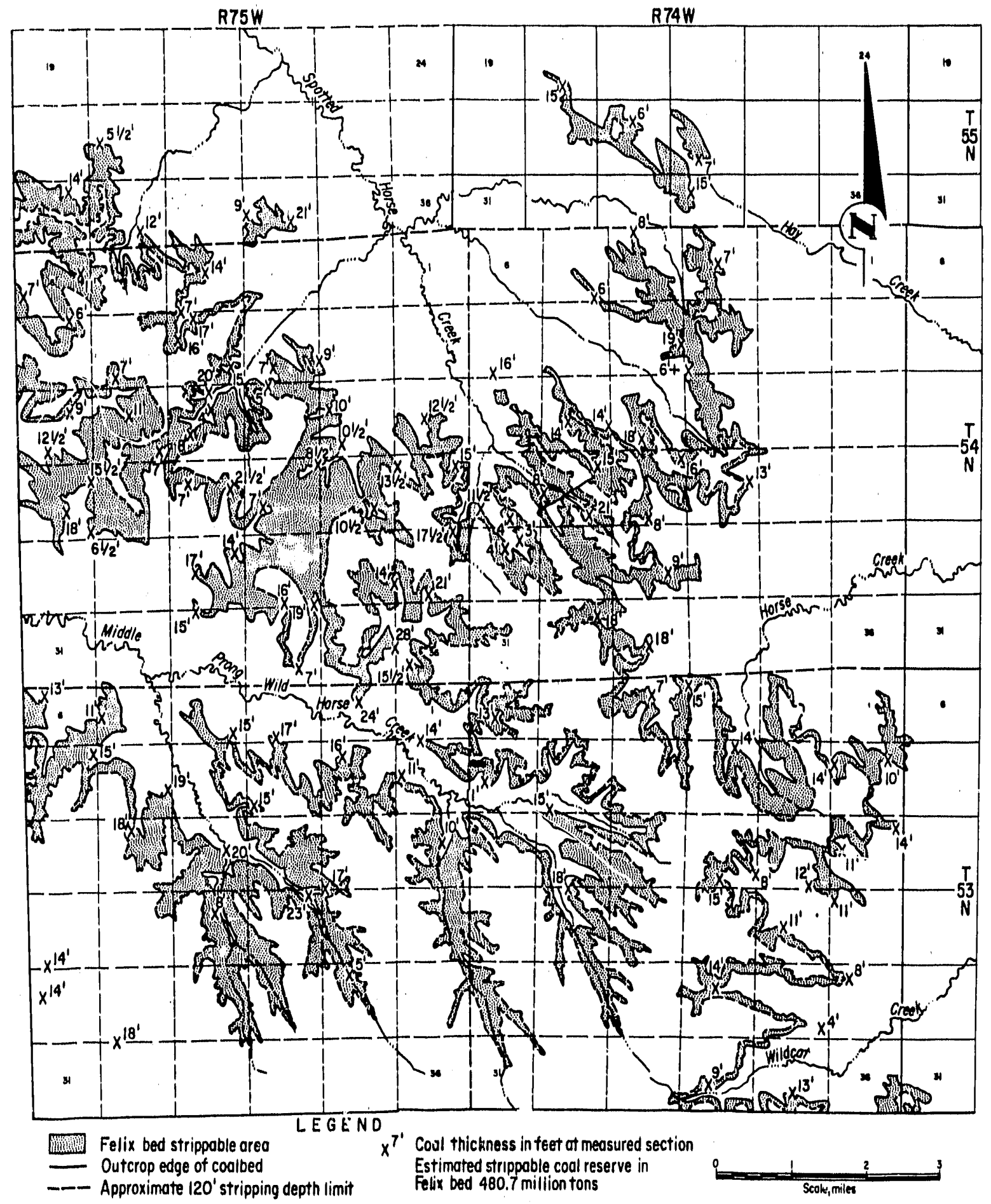

Figure 6. Felix deposit, Spotted Horse area (based on Plate 2, U.S. Geological Survey Bulletin 1050) (after Sinlth and others, 1972). 


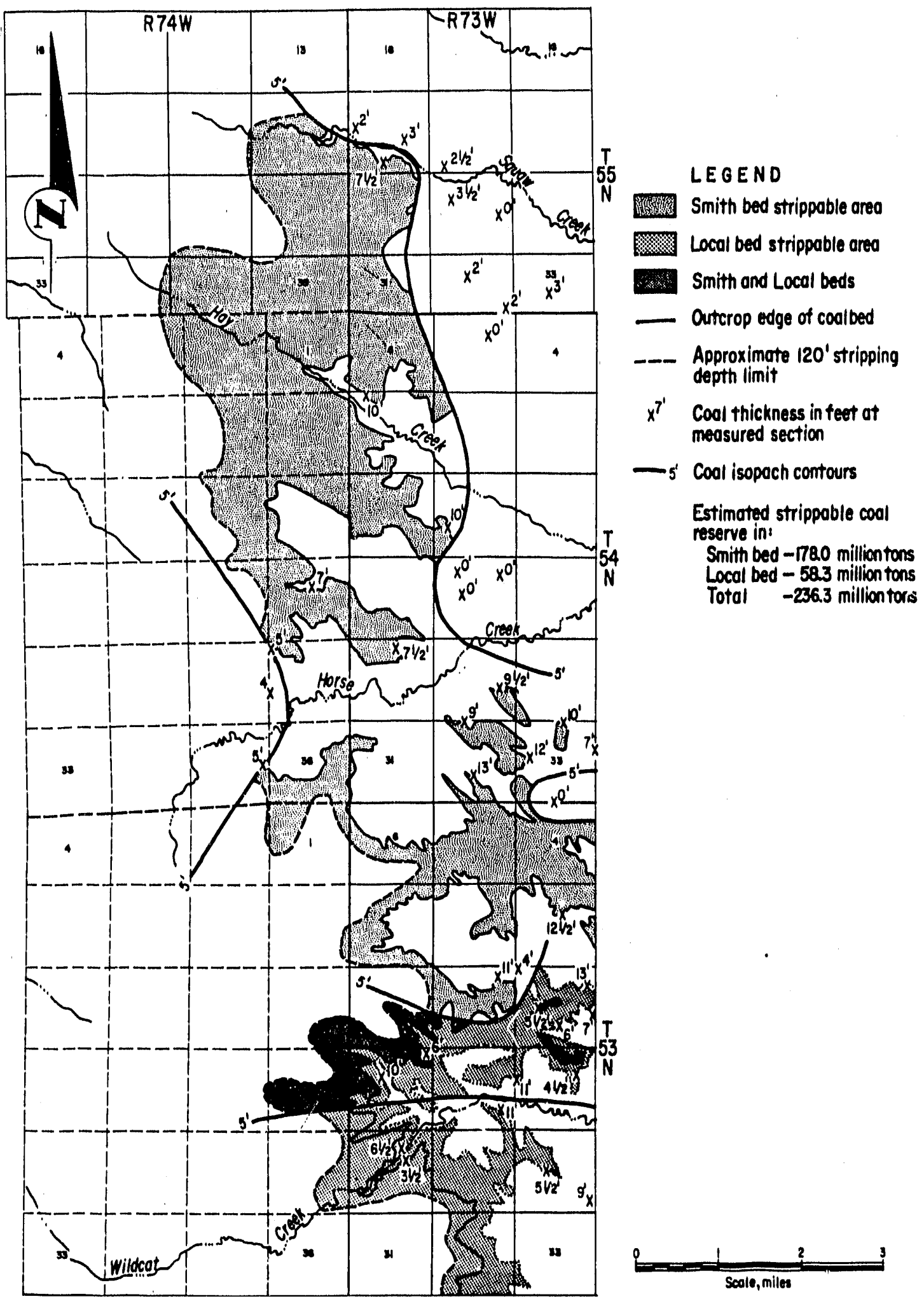

Flgure 7. Smith-Local deposit, Spotted Horse area (based on Plate 2, U.S. Geological Survey Bulletin 1050) (after Smith and others, 1972). 
Felix are located south of the area in Figure 6. Coal analyses used to characterize this deposit are listed in Table 6. The Smith coal bed of the Fort Union Formation was characterized by a single partial analysis. Local coal beds below the Smith were assigned the same quality as that used for the Smith coal bed. Only one analysis for the Felix coal bed was found within the area of the DRB, but because nearby townships showed similar values for the Felix, all the analyses were combined as a weighted average to represent the Felix bed in this deposit. For the other Wasatch Formation coals in this deposit, a single analysis was found for the Truman coal bed, one partial analysis was found for the Scott coal bed, and no analyses were fo und for the Parnell or Daly beds. A weighted average of analyses from the Truman, Scott, and two other coals from the Wasatch Formation was used to represent the Wasatch coals in this deposit (Table 6).

9. Sussex Deposit. The Sussex deposit (Figure 8) contains 13.6 million tons of coal in Fort Union Formation coal beds in Sussex Coal Basin No. 4 (Smith and others, 1972). A zone of uncorrelated coal beds in the area (see points $J$ and K, Figure 9) contains beds up to 50 feet thick in places with an average thickness of 11.8 feet (Smith and others, 1972). Strippable coal is found in a band parallel to the outcrop at depths of 120 feet or less. Only four coal analyses were available for this deposit (Table 7); the data was insufficient to develop weighted average values.

10. Wyarno-Verona Deposit. The Wyarno-Verona deposit (Figure 9) contains 1.8 billion tons of potentially strippable coal in beds greater than 10 feet thick (Culbertson and Mapel, 1976). Most of these coal beds are shown in Figure 1. Analyses for the Wasatch Formation coal beds in this deposit are shown in Table 8. Two analyses of samples from the PK coal bed were available; unfortunately, one of these analyses was from a sample collected from a weathered outcrop and could not be used. The Ulm 2 or Lower Ulm coal bed, correlated with the Healy bed by Cuiveritson and Mapel (1976), is represented by 9 usable analyses. Four analyses were available for the Ulm 1 or Upper Ulm coal bed; unfortunately, all these analyses were of samples from weathered outcrops and could not be used to characterize the qua lity of this coal bed. The other Wasatch coals in this deposit were characterized b: analyses of the Bar N, Dow, Rimrock, Intermediate Ulm, Ulm (undivided), Wyarno, and some local unnamed coal beds. Unfortunately, 8 of these 29 analyses were of samples from weathered or oxidized coai and could not be used with any reliability. The weighted average heat values and sulfur contents of these coals (based on the remaining 21 coal analyses) are 14.46 million Btu/short ton and $3.07 \mathrm{lbs}$ sulfur/million Btu, respectively. 


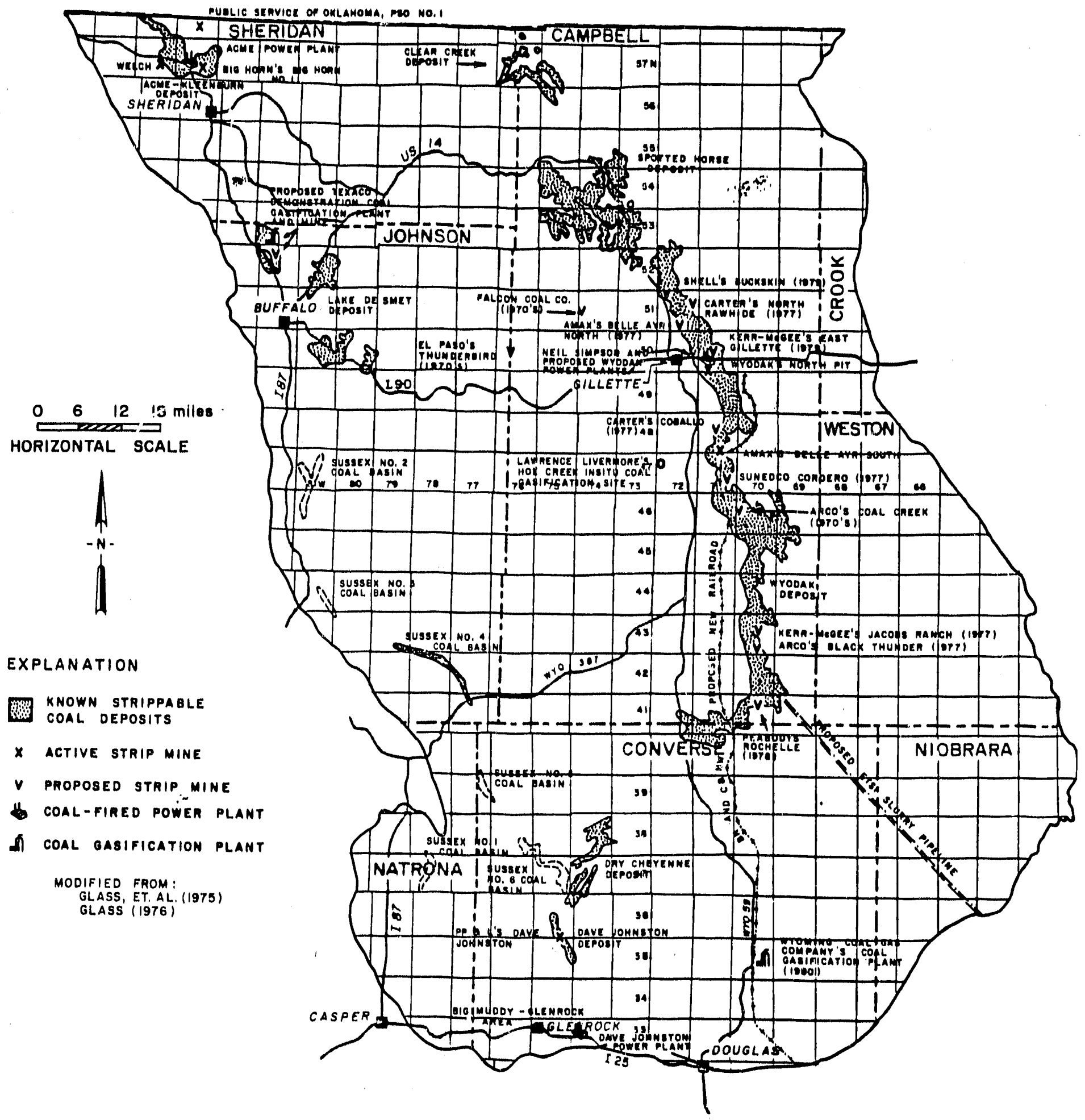

Figure 8. Location of Sussex deposit (modified from Figure 4 of Glass, 1976). 


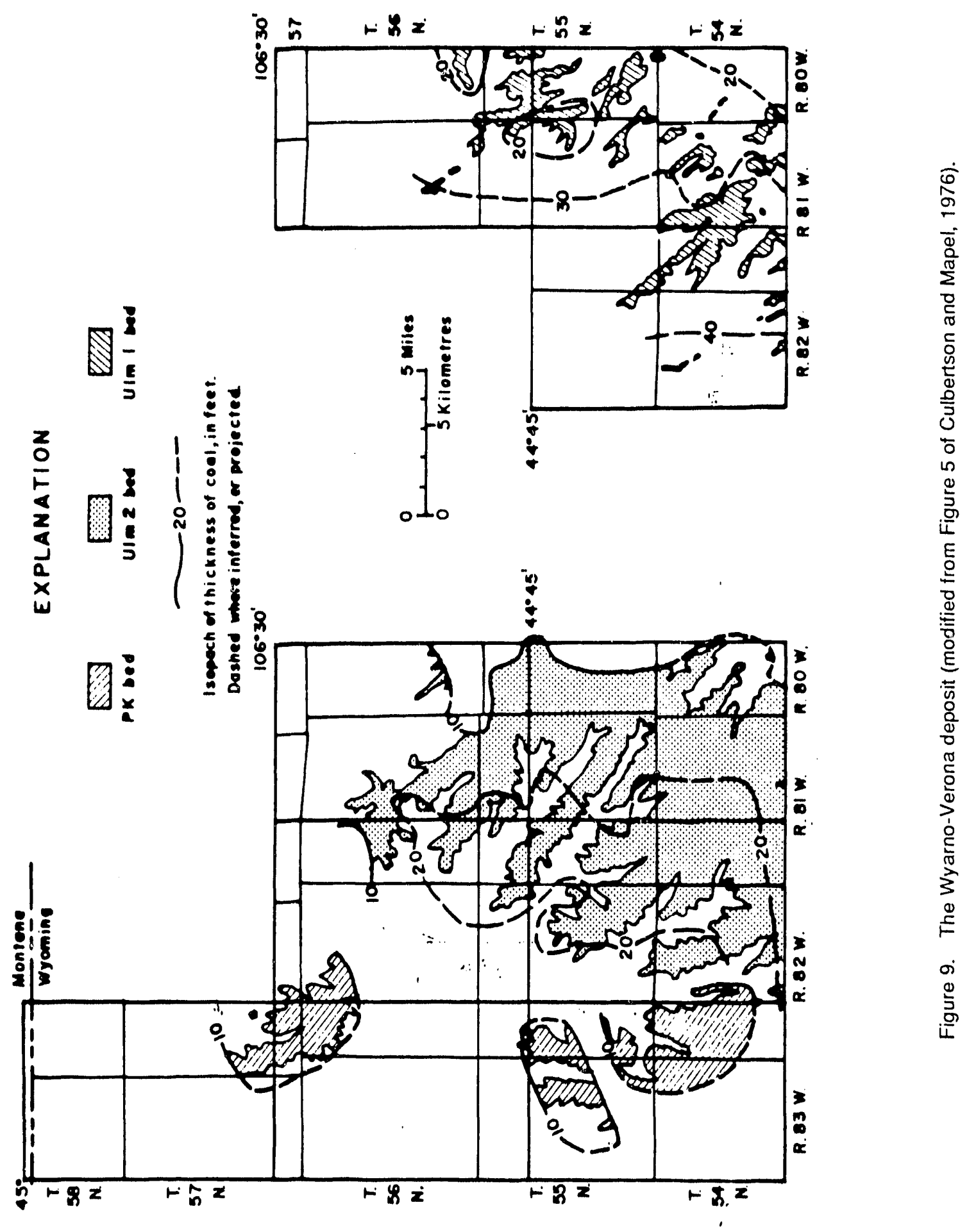




\section{REFERENCES CITED}

Culbertson, W.C., and Mapel, W.J., 1976, Coal in the Wasatch Formation, northwest part of the Powder River Basin, near Sheridan, Sheridan County, Wyoming: Wyoming Geological Association 28th Annual Field Conference Guidebook, p. 193201.

Glass, G.B., 1976, Update on the Powder River coal basin: Wyoming Geological Association 28th Annual Field Conference Guidebook, p. 209-220.

Glass, G.B., 1981, Coal deposits of Wyoming: Wyoming Geological Association 32nd Annual Field Conference Guidebook, p. 181-236.

Glass, G.B., 1985, Coal deposits of Wyoming in Keystone Coal Industry Manual: McGraw-Hill, New York, p. 610-636.

Glass, G.B., and Jones, R.W., 1991, Coal fields and coal beds of Wyoming: Wyoming Geological Association 42nd Field Conference Guidebook, p. 133-167.

Mapel, W.J., 1959, Geology and coal resources of the Buffalo-Lake De Smet area, Johnson and Sheridan Counties, Wyoming: U.S. Geological Survey Bulletin 1078, $148 \mathrm{p}$.

Warwick, P.D., 1985, Depositional environments and petrology of the Felix coal interval (Eocene), Powder River Basin, Wyoming: Ph.D. Dissertation, University of Kentucky, $349 \mathrm{p}$. 


\section{APPENDIX D: DEMONSTRATED RESERVE BASE OF STRIPPABLE COAL IN THE ADAVILLE FORMATION, ADAVILLE (KEMMERER) AND SOUTH HAYSTACK DEPOSITS, HAMS FORK COAL FIELD, WYOMING.}




\section{List of Tables}

Table 1. Summary of remaining demonstrated reserve base (DRB) of the Adaville and South Haystack coal

deposits through December 31, 1990 (in million short tons)

D.3

Table 2. Original demonstrated reserve ba:se (DRB), mining losses and remaining DRB, Adaville coal deposit (in short tons). Numbers in parentheses are negative

Table 3. Sulfur and heating values from analyses of core and channel samples

in the Adaville and South Haystack coal deposits, Hams Fork Coal Field

Table 4. Sulfur and heating values from analyses

of tipple and delivered coal samples in the Adaville

and South Haystack coal deposits, Hams Fork Coal Field

D-9

\section{List of Figures}

Figure 1. Major coal beds in the Adaville Formation,

Hams Fork Coal Field, Wyoming (from Glass, 1981)

Figure 2. Location map of the South Haystack strippable coal deposit,

Uinta County, Wyoming (from Rocky Mountain Energy, 1981)

Figure 3. Location map of the Adaville strippable coal deposit,

Lincoln County, Wyoming (from Smith and others, 1972)

D.13 
1. Summary. The remaining demonstrated reserve base (DRB) of strippable coal in the Adaville and South Haystack deposits to January 1, 1991, is about 935 million short tons (Table 1). The Adaville deposit, which consists of two unmined permit areas and the active Kemmerer and Skull Point coal mining areas, contains nearly 870 million tons of coal. Another 65 million tons of coal in the DRB occurs in the South Haystack area. About 23 percent (218 million tons) of the total remaining DRB has a heating content of $20.00-22.99$ million Btu/short ton; the other 716 million tons of coal has a heating content of 15.00 to 19.99 million Btu/short ton. About 42 percent (395 million tons) of the remaining DRB in the Adaville and South Haystack coal deposits contains less than $0.60 \mathrm{lbs}$ sulfur/million Btu and almost 58 percent (538 million tons) of the remaining DRB contains $0.61-0.83 \mathrm{lbs}$ sulfur/million Btu.

Table 1. Summary of remaining demonstrated reserve base (DRB) of the Adaville and South Haystack coal deposits through December 31, 1990 (in million short tons).

\begin{tabular}{|c|c|c|c|c|c|c|c|c|}
\hline \multirow[b]{2}{*}{ Seam } & \multirow{2}{*}{$\begin{array}{l}\text { Btu Content } \\
\text { million Btu/ } \\
\text { short ton }\end{array}$} & \multicolumn{6}{|c|}{$\begin{array}{c}\text { Sulfur Content } \\
\text { (lbs sulfur/million Btu) }\end{array}$} & \multirow{2}{*}{$\begin{array}{c}\text { Total } \\
\text { All Sulfur } \\
\text { Categories }\end{array}$} \\
\hline & & 50.40 & $0.41-0.60$ & $0.61-0.83$ & $0.84-1.67$ & $1.68-2.50$ & $>2.50$ & \\
\hline \multicolumn{9}{|c|}{ Adaville Deposit - Twin Creek and North Block permit areas } \\
\hline All Adaville beds & 15.19 .99 & - & - & 320.00 & - & - & - & 320.00 \\
\hline \multicolumn{9}{|c|}{ Adaville Deposit-Kemmerer and Skull Point mining areas } \\
\hline Adaville No. 1 & $20-22.99$ & - & - & 218.20 & - & - & - & 218.20 \\
\hline $\begin{array}{l}\text { Beds above } \\
\text { Adaville No. } 1\end{array}$ & $15-19.99$ & - & 331.54 & - & - & - & - & 331.54 \\
\hline \multicolumn{9}{|c|}{ South Haystack permit area } \\
\hline $\begin{array}{l}\text { Adaville No. } 1 \\
\& \text { No. } 1 \mathrm{~A}\end{array}$ & $15-19.99$ & - & - & - & 1.85 & - & - & 1.85 \\
\hline $\begin{array}{l}\text { Beds above } \\
\text { Adaville No. } 1\end{array}$ & $15-19.99$ & 63.00 & - & - & - & - & - & 63.00 \\
\hline Subtotals & $\begin{array}{l}15-19.99 \\
20-22.99\end{array}$ & $\stackrel{63.00}{-}$ & $\begin{array}{c}331.54 \\
-\end{array}$ & $\begin{array}{l}320.00 \\
218.20\end{array}$ & $\frac{1.85}{-}$ & - & $\overline{-}$ & $\begin{array}{l}716.39 \\
218.20\end{array}$ \\
\hline $\begin{array}{l}\text { Total All } \\
\text { Sulfur Categories }\end{array}$ & & 63.00 & 331.54 & 538.20 & 1.85 & - & - & 934.59 \\
\hline
\end{tabular}

2. Methodology. Original DRB tonnages were taken from Smith and others (1972) for the Adaville deposit and from Glass (1981) for the South Haystack area. Only the Adaville deposit required a tonnage adjustment due to mining and production losses 
(Table 2). This was done by first subtracting coal resources contained in two unmined tracts (North Block and Twin Creek) from the original one billion tons of strippable DRB and then apportioning the remaining 680 million tons to the Adaville No. 1 coal bed and all the coal beds above the Adaville No. 1, respectively, on the basis of average thickness(es) within the area.

The Adaville No. 1 coal bed averages about 82 feet thick over most of the area while the total combined thickness of coal beds above the Adaville No. 1 averages about 118 feet (Figure 1). The 200-foot average thickness of all coal beds in the Adaville deposit is the same thickness used by Smith and others (1972) in their estimate of surface minable (strippable) resources for the deposit. Unique geologic conditions in this deposit (multiple, thick, relatively steeply-dipping coal beds or coal zones) allow for extraction of numerous coal beds in a large open pit operation. Coals can be recovered a total highwall height of up to 1,400 feet. In this deposit (as in many other coal deposits in Wyoming), "surface minable coal" is probably a more appropriate term than "strippable coal".

Table 2. Original demonstrated reserve base (DRB), mining losses, and remaining DRB, Adaville coal deposit (in short tons). Numbers in parentheses are negative.
A. Original DRB, Adaville area (from Smith and others, 1972)
$1,000,000,000$
B. Unmined DRB in Twin Creek and North Block permit areas
$320,000,000$
C. Original DRB remaining in Kemmerer/Skull Point mining area (A-B)
$680,000,000$
D. Original DRB for Adaville No. 1 in the Kemmerer/Skull Point mining area $(41 \%$ of $C)$
$278,800,000$
Less coal production through 1990
$(40,205,029)$
Less mining losses $25 \%$ recovery factor for underground coal and $80 \%$ recovery factor for surface coal)
$(20,393,103)$
Remaining DRB for Adaville No. 1
$218,201,868$
E. Original DRB for all coal beds above Adaville No. 1 in the
Kemmerer/Skull Point mining area (59\% of C)
$401,200,000$
Less coal production through 1990
$(55,725,469)$
Less mining losses ( $80 \%$ recovery factor for surface coal)
$(13, \underline{91}, 367)$
Remaining DRB for coal beds above Adaville No. 1
$331,543,164$
F. Remaining DRB in the Kemmerer area $(B+D+E)$ as of January $1,1991$.
$869,745,032$ 


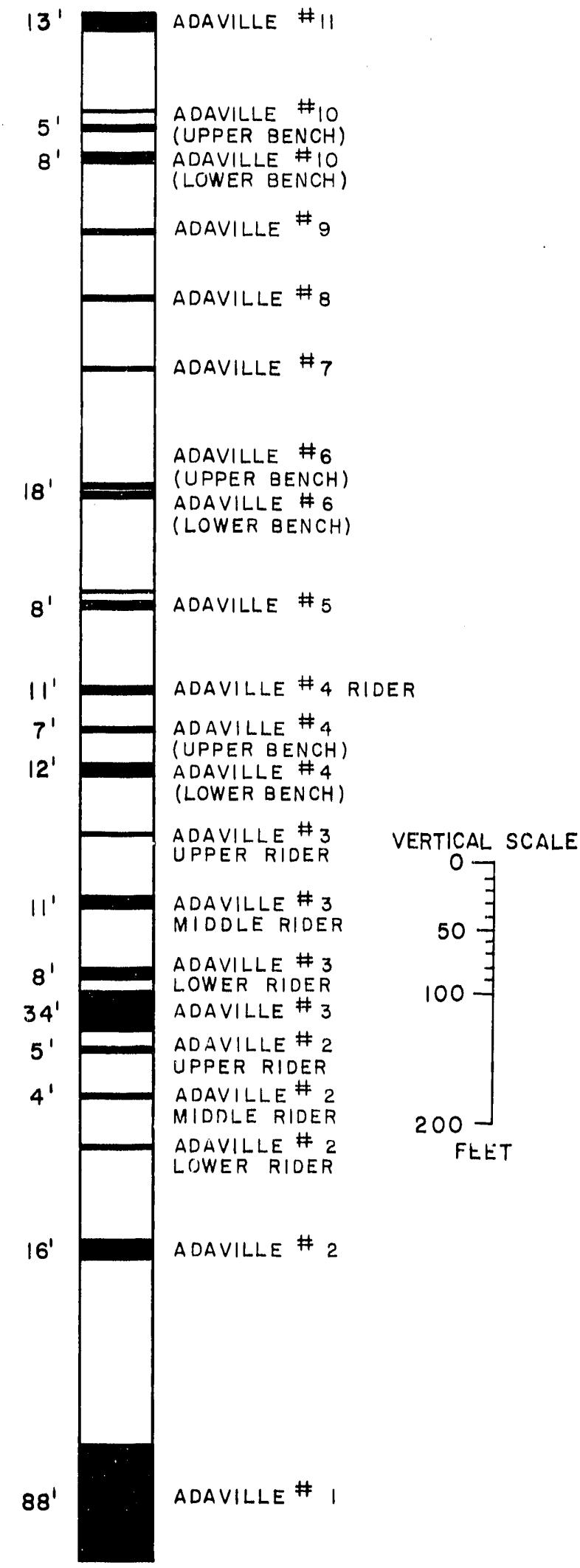

Figure 1. Major coal beds in the Adaville Formation, Hams Fork Coal Field, Wyoming (from Glass, 1981). 
Production and mining losses were calculated using a recovery factor of 80 percent for surface-mined coal and 25 percent for underground-mined coal. An adjustment for underground-mined coal was necessary because the Elkol underground coal mine, which operated from 1909 to 1950 , produced from the Adaville No. 1 coal bed. This same coal bed was subsequently extracted by surface mining adjacent to the Elkol underground mine; both the underground coal produced and the remaining underground coal reserves are now included as part of the strippable coal reserve area. An 80 percent recovery factor means that 80 percent of the thtal coal in-place was recovered and 20 percent of the coal in-place was not recovered because of mining losses and other inefficiencies. The 25 percent recovery factor assigned to underground production from the Elkol mine was based on the relatively small portion of the 80 to 90 -foot-thick Adaville No. 1 coal bed that was recovered through underground mining.

Sulfur contents and heating values for the Twin Creek, South Haystack, and North Block mining permit areas were derived from data contained in their respective mine plans. For the remaining areas, sulfur and heating values were based on weighted average analyses of core and channel samples as well as weighted average analyses of tipple and delivered samples of produced coal. Analytical data for all coal beds above the Adaville No. 1 bed were combined and an average sulfur content and heating value determined; analyses of the Adaville No. 1 coal bed were also averaged and the sulfur content and heating value determined. Average analyses that were weighted by the amount of resources present in each coal bed were available for the South Haystack coal deposit. For this area, average heating values and sulfur contents were assigned to the Adaville No. 1 coal bed(s) and to the coal beds above the Adaville No. 1.

3. Analyses. Coal analyses used in this report were taken from various published and unpublished sources (Tables 3 and 4). All analyses were evaluated on an individual basis. Analyses from uncorrelated coal beds or poorly located data points were not used. Where only partial thicknesses of a coal bed were sampled and analyzed and no other information was available nearby, the data were not considered representative of the entire coal bed and were not used in this study. Where only partial thicknesses of a coal bed were sampled and analyzed and there was other information on coal thickness and quality (of complete coal beds) available nearby, the analyses were weighted by linear footage sampled. Tipple and delivered coal samples were weighted according to the tonnage each collected sample represented. 


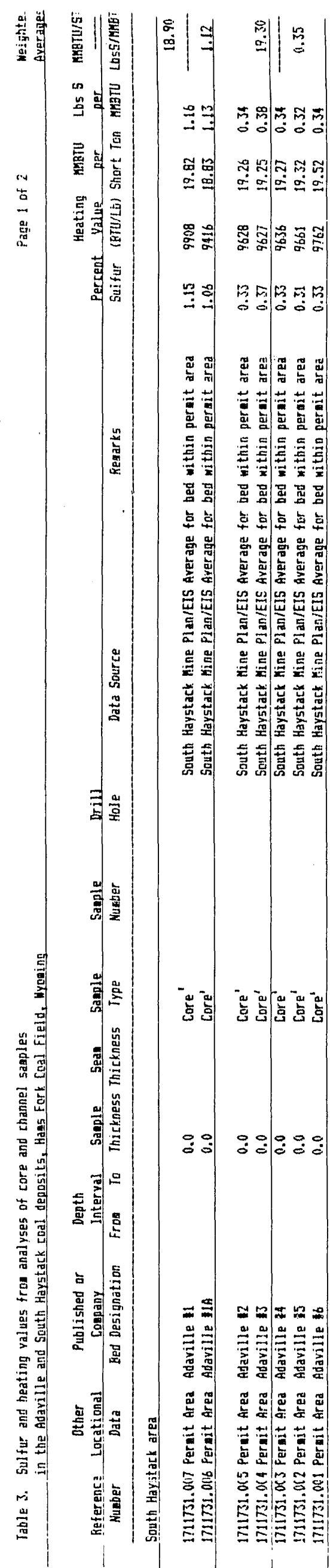

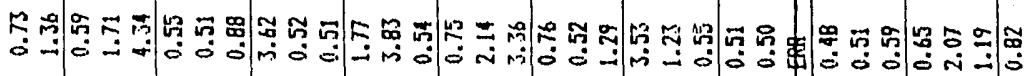

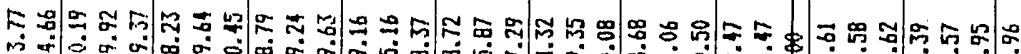

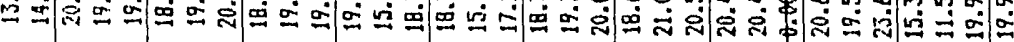

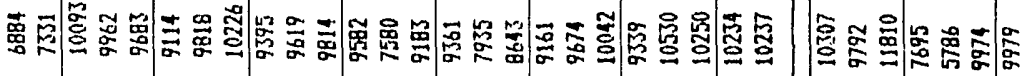

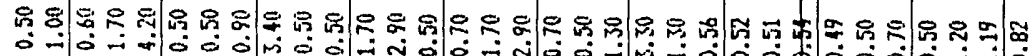

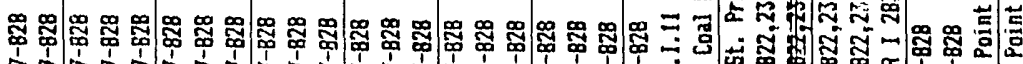

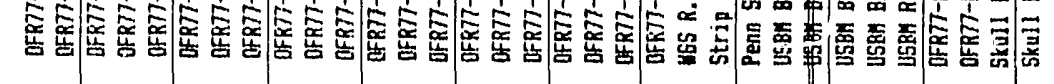

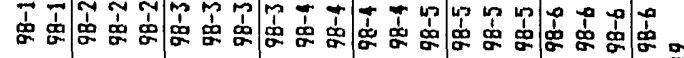
䓌志

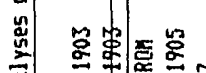

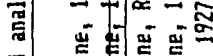

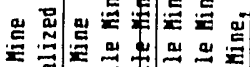

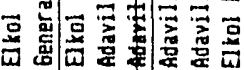

舜罢

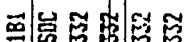

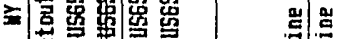

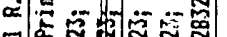
运: 咅

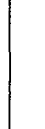

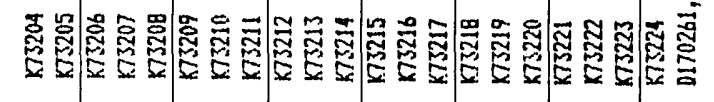

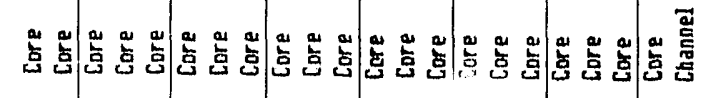

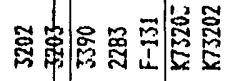

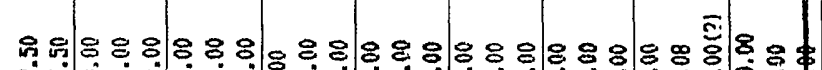

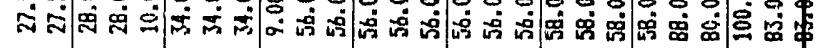

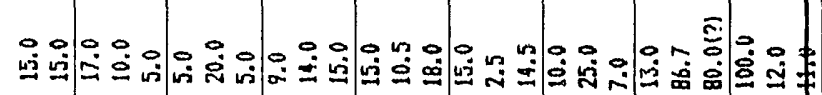

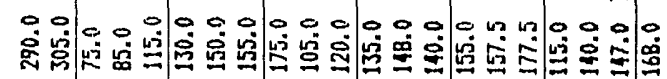

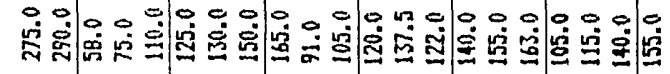

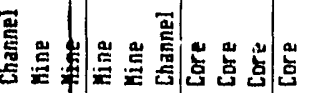

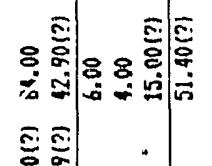

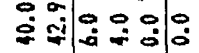
옹영 路官

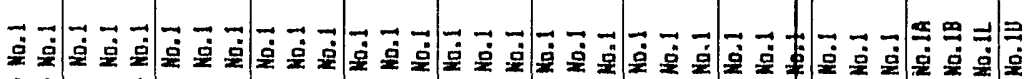

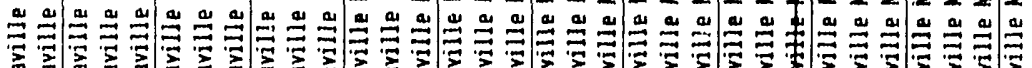

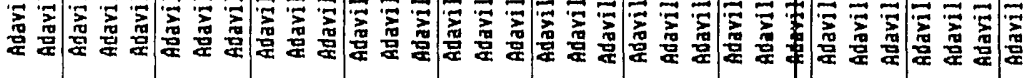




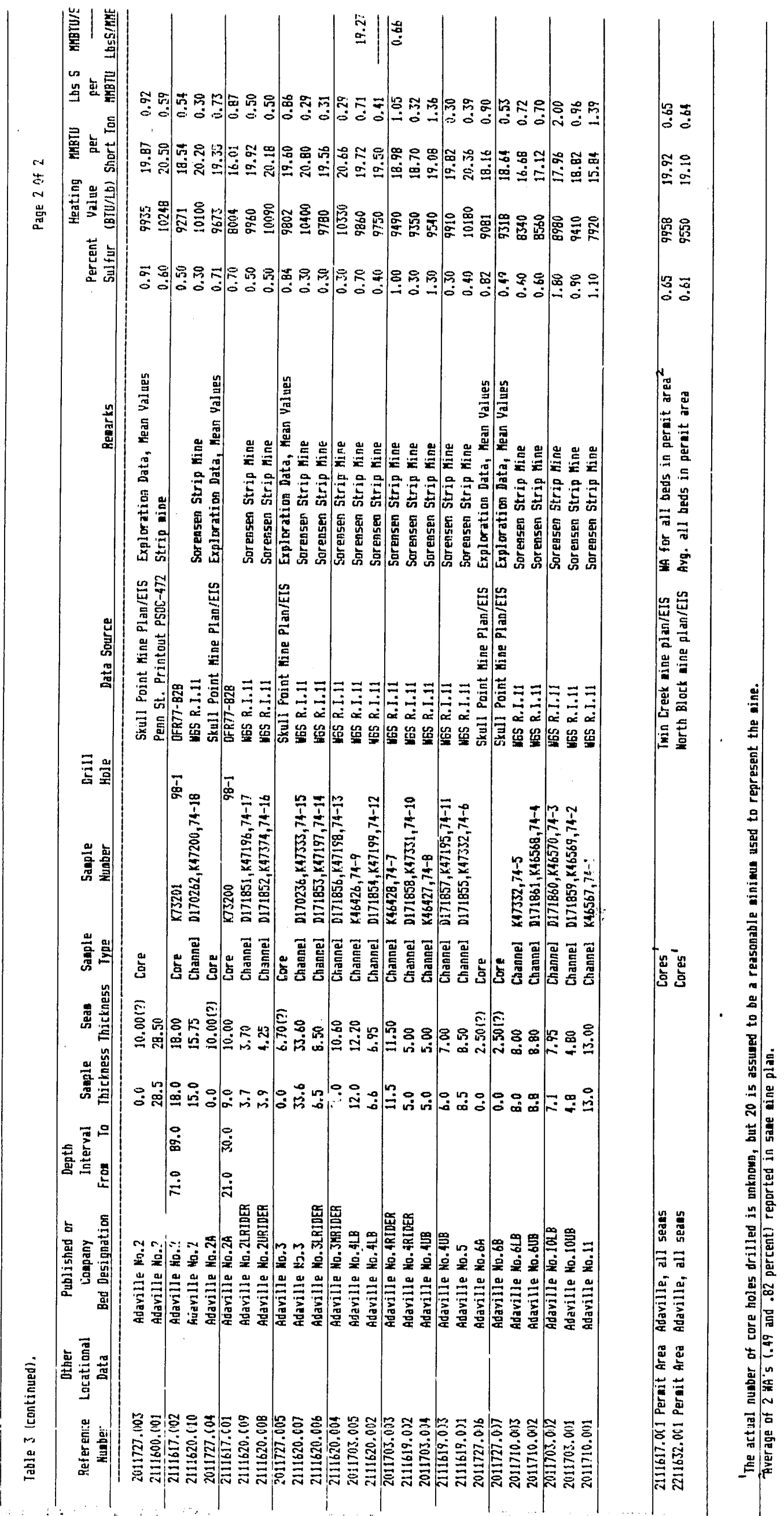




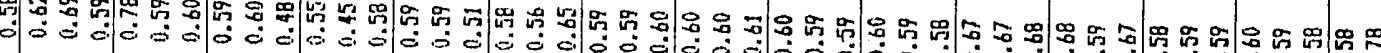

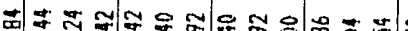

몽

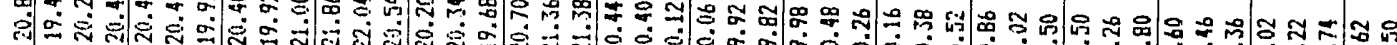
善司焉

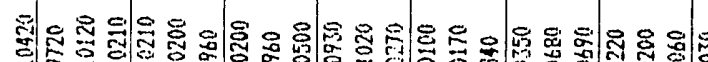

善急

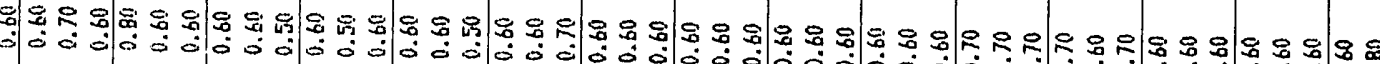
$=2 \frac{9}{2}$

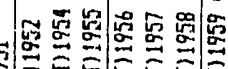

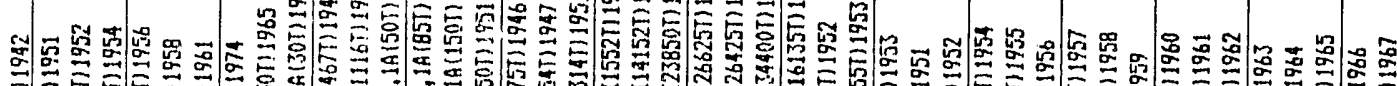

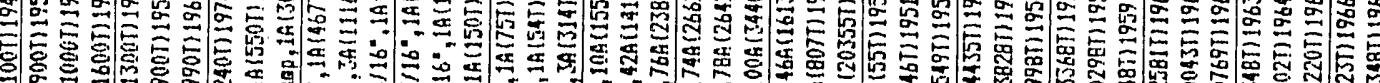

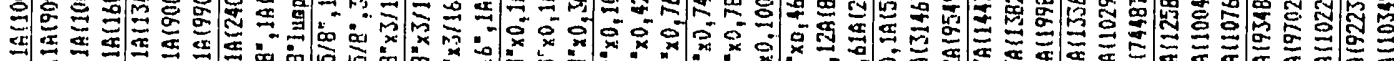

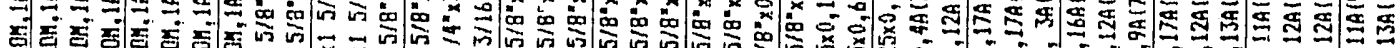
0ิ

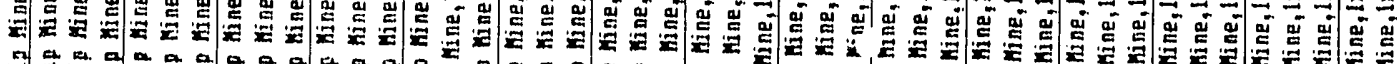

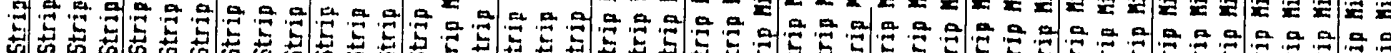

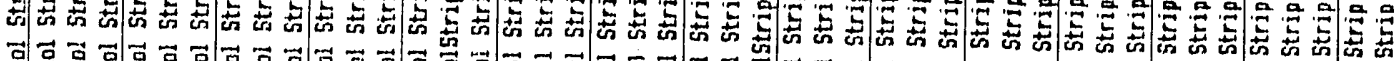

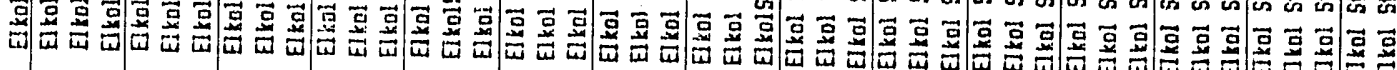

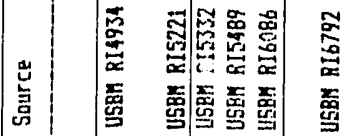

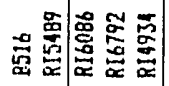

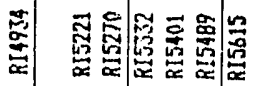

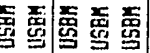

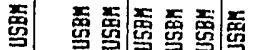

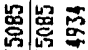

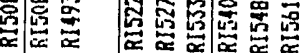

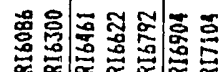
䒿

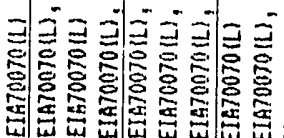

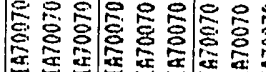
要要

司蓓

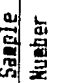

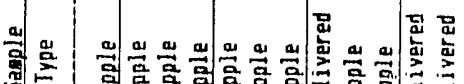

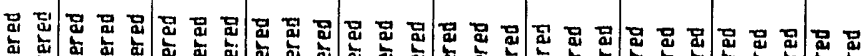

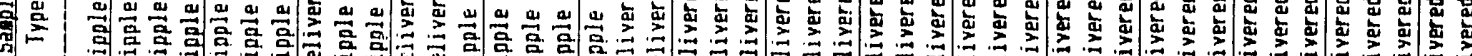

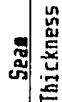

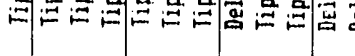

$\frac{a}{3}$

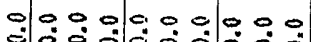

푼

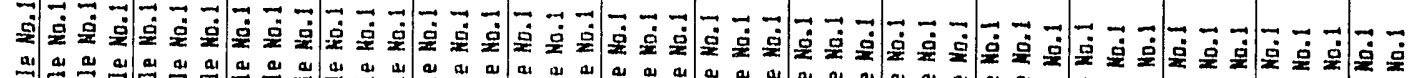

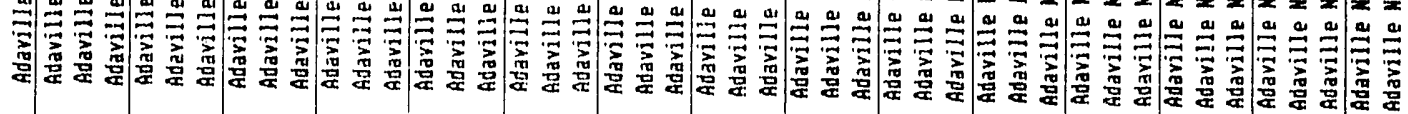

害递密

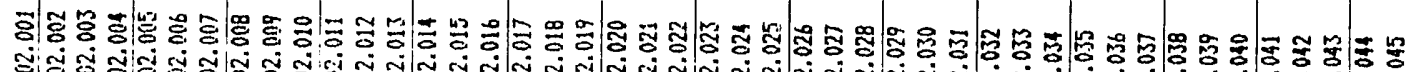

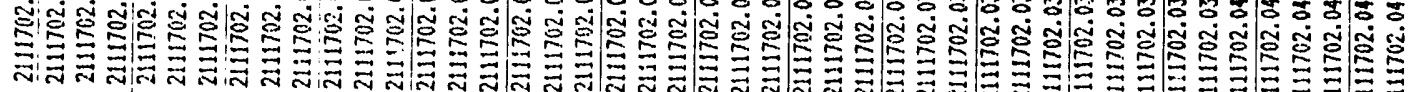




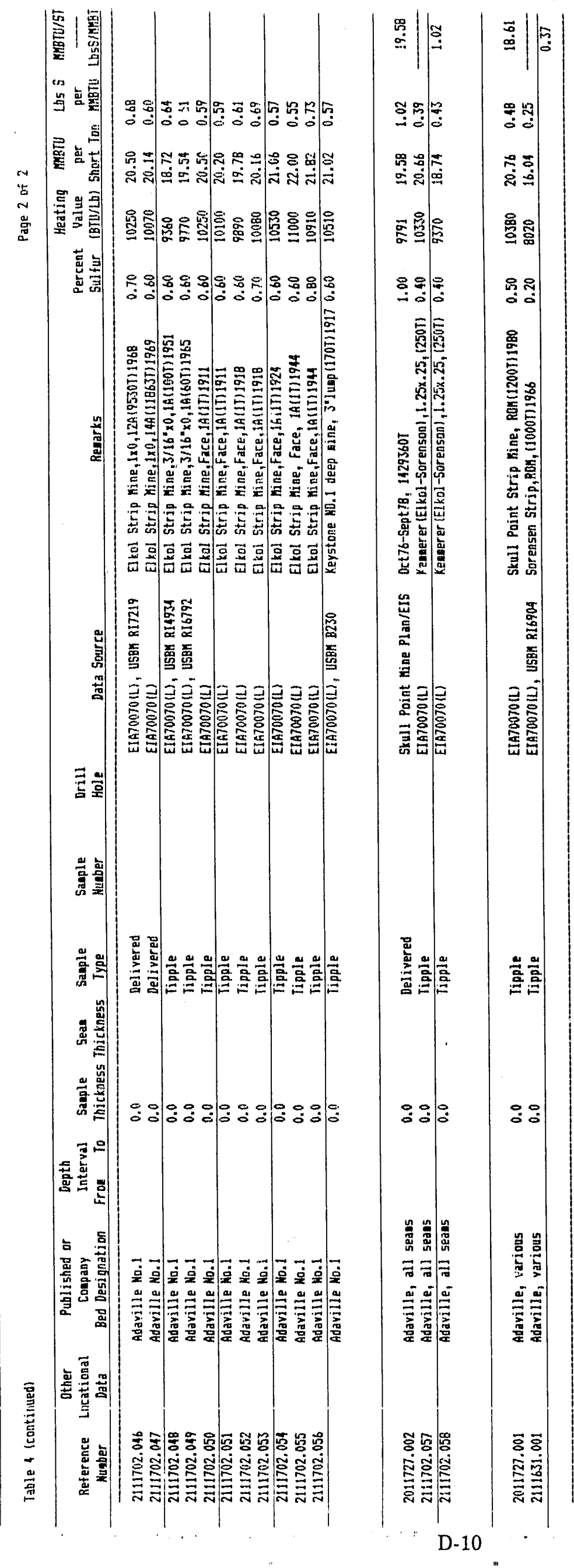


4. South Haystack deposit. This coal deposit (Figure 2) is located about 12 miles south of the Adaviile coal deposit and contains seven surface-minable coal beds in the Upper Cretaceous Adaville Formation (Figure 1). The Adaville No. 1 and 1A coal beds (Table 3 ) contain 1.85 million tons of DRB coal with a heating value of $15.00-19.99$ million Btu/short ton and a sulfur content of $0.84-1.67 \mathrm{lbs}$ sulfur/million Btu (Table 1). The Adaville No. 2 through 6 coal beds contain a combined DRB of 63 million tons. Although these five coal beds are in the same heating value category as the Adaville Nos. 1 and $1 \mathrm{~A}$, the sulfur content of these five coal beds (less than $0.40 \mathrm{lbs}$ sulfur/million Btu) is much lower than the sulfur conten $\downarrow$ of the Adaville Nos. 1 and $1 \mathrm{~A}$ (Table 1).

5. Adaville (Kemmerer) deposit. This coal deposit is located within a 20-mile long, north-south trending strip west of Kemmerer (Figure 3) and contains up to 32 coal beds in the Upper Cretaceous Adaville Formation. Figure 1 shows the major surfaceminable Adaville Formation coal beds in this deposit. About 870 million tons of strippable DRB coal remain in this deposit. The Twin Creek and North Block permit areas contain about 320 million tons of the DRB in various Adaville coal beds (Table 1). The available data (Table 3 ) did not allow separate coal quality categories to be determined for the Adaville No. 1 or for the coal beds above the Adaville No. 1 in these areas. DRB coal in the Twin Creek and North Block permit areas contains $0.61-0.83$ lbs sulfur/million Btu and from 15.00 - 19.99 million Btu/short ton (Table 1).

The 550 million tons of remaining strippable DRB in the Adaville deposit outside the Twin Creek and North Block permit areas can be separated into about 218 million tons of coal in the Adaville No. 1 coal bed and about 332 million tons of coal in beds above the Adaville No. 1 (Table 1). The Adaville No. ì coal bed contains, on average, both a higher heating value and a higher sulfur content than coal beds above it. The coal from the Adaville No. 1 condains a heating value of $20-22.99$ million Btu/short ton and a sulfur content of $0 . \dot{r} 1$ - $0.83 \mathrm{lbs}$ sulfur/million Btu. Coal beds above the Adaville No. 1 contain 15.00 - 19.99 million Btu/short ton and $0.41-0.60 \mathrm{lbs}$ sulfur/million Btu. About 96 million tons of coal has been produced from the Adaville deposit through 1990; an additional 34 miliion tons of coal were lost through mining efficiencies and incomplete recovery (see Table 2 ). 


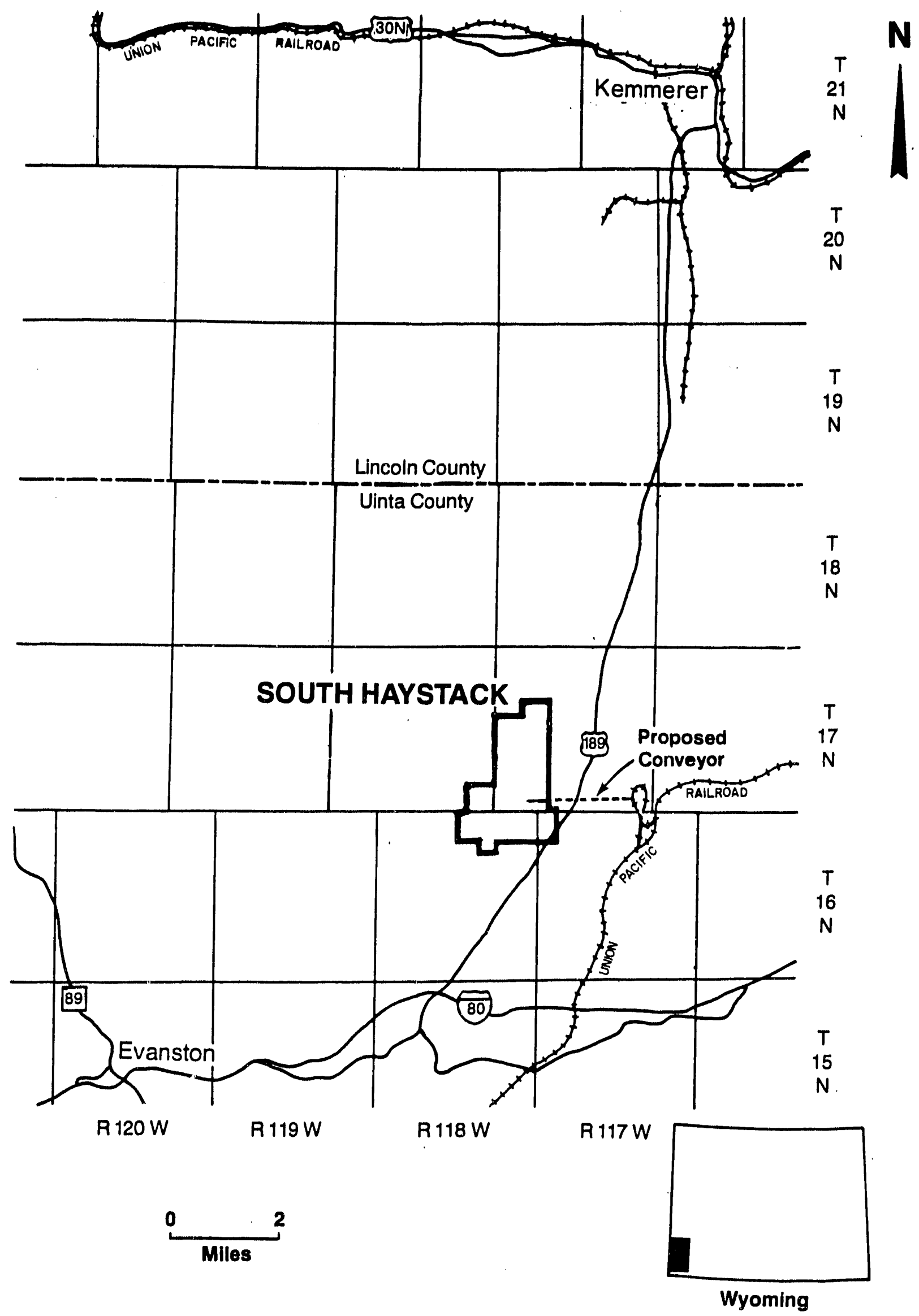

Figure 2. Location inap of the South Haystack strippable coal deposit, I Jinta County, Wyoming (from Rocky Mountain Energy Company, 1981).

D-12 


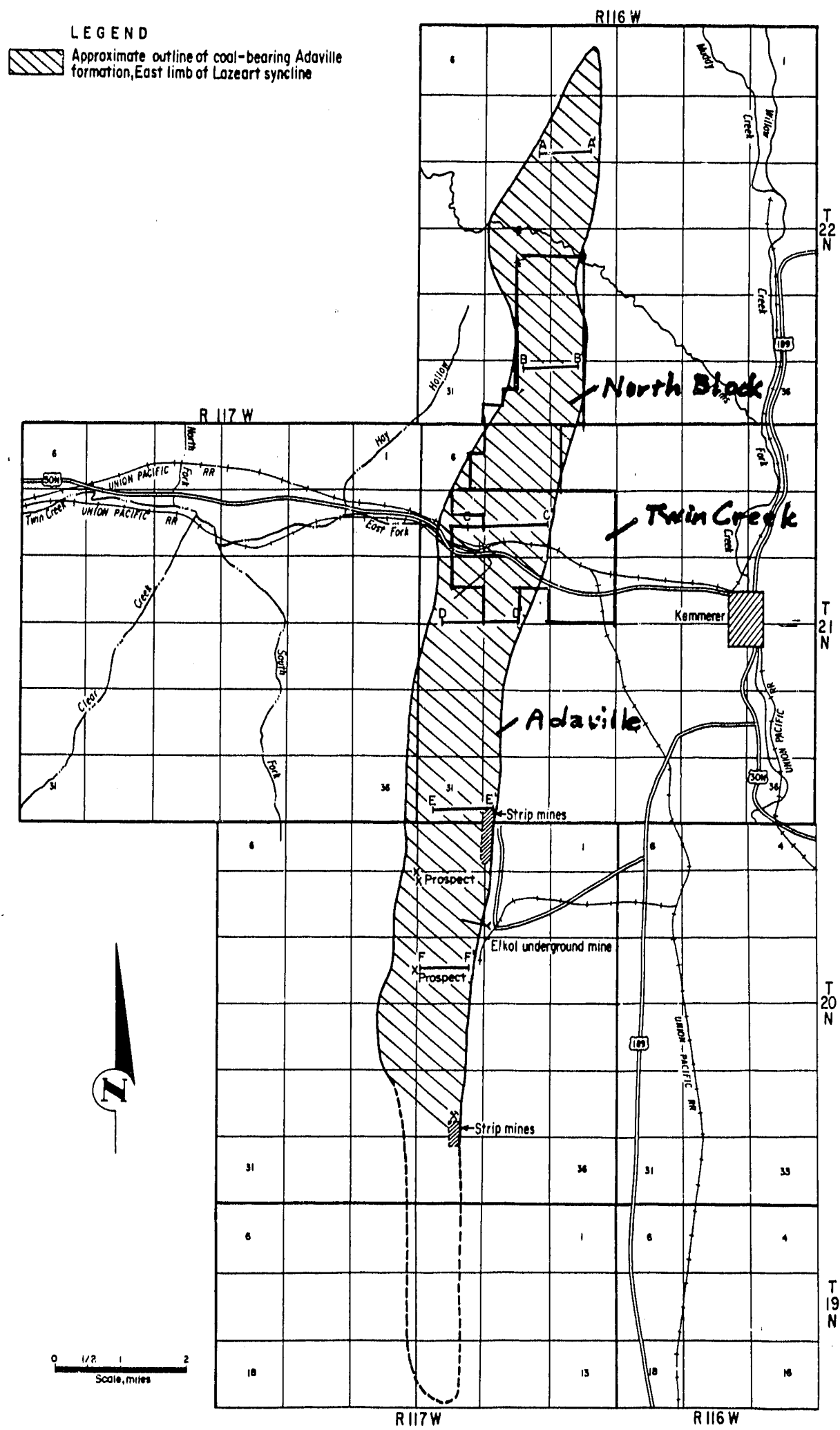

Figure 3. Location map of the Adaville strippable coal deposit, Lincoln County, Wyoming (from Smith and others, 1972). 


\section{REFERENCES CITED}

Glass, G.B., 1981, Coal deposits of Wyoming: Wyoming Geological Association 32nd Annual Field Conference Guidebook, p. 181-236.

Rocky Mountain Energy Company, 1981, Project activity update, March, 1981: Rocky Mountain Energy Company informational publication, $32 \mathrm{p}$.

Smith, J.B., Ayler, M.F., Knox, C.C., and Pollard, B.C., 1972, Strippable coal reserves of Wyoming: U.S. Bureau of Mines Information Circular 8538, 51 p. 
APPENDIX E. DEMONSTRATED RESERVE BASE OF STRIPPABLE COAL IN THE RED DESERT, CRESTON-CHEROKEE, NORTHERN LITTLE SNAKE RIVER, JIM BRIDGER, LEUCITE HILLS, BLACK BUTTE, AND SALT WELLS DEPOSITS, GREEN RIVER COAL FIELD, WYOMING. 


\section{List of Tables}

Page

Table 1. Summary of remaining demonstrated reserve base (DRB)

of strippable coal deposits in the Green River Coal Field,

Wyoming, through December 31, 1990 (in million short tons)

E-4

Table 2. Sulfur and heating values for the Red Desert

strippable coal deposit, Green River Coal Field, Wyoming

Table 3. Sulfur and heating values for the Creston-Cherokee

strippable coal deposit, Green River Coal Field, Wyoming

Table 4. Sulfur and heating values for the Northern Little

Snake River strippable coal deposit, Green River Coal Field, Wyoming

Table 5. Sulfur and heating values for the Jim Bridger

strippable coal deposit, Green River Coal Field, Wyoming

Table 6. Sulfur and heating values for the Jim Bridger

strippable coal deposit, Green River Coal Field, Wyoming

Table 7. Sulfur and heating values for the Black Butte

strippable coal deposit, Green River Coal Field, Wyoming

Table 8. Sulfur and heating values for the Salt Wells

strippable coal deposit, Green River Coal Field, Wyoming E-16

\section{List of Figures}

Figure 1. Location map of estimated strippable reserves, Red Desert coal deposit, Great Divide Basin area. (From Figure 11 of Smith, 1972; based on Pipiringos, 1961, and Masursky, 1962)

Figure 2. Approximate stratigraphic position and correlation of coal beds and coal zones in the Red Desert strippable deposit. Black dots indicate coal beds with demonstrated reserve base coal (from Plate 1 of Masursky, 1962)

Figure 3. Map showing location of estimated strippable reserves, Creston-Cherokee coal deposit, Sweetwater and Carbon Counties, Wyoming (outline from Rocky Mountain Energy Company, 1976)

Figure 4. Stratigraphic column of the Cherokee and other Fort Union Formation coal beds, Creston-Cherokee strippable coal deposit, Green River Coal Field, Wyoming (from Northern Energy Resources Company, 1977a)

Figure 5. Map showing location of estimated strippable reserves, Northern Little Snake River coal deposit, Carbon County, Wyoming (compiled from Rocky Mountain Energy Company, 1976) 
Figure 6. Map showing location of estimated strippable

reserves, Jim Bridger coal deposit, Sweetwater County,

Wyoming (from Northern Energy Resources Company, 1977b)

Figure 7. Location map of estimated strippable

reserves, Leucite Hills coal deposit, Sweetwater County,

Wyoming (from Rocky Mountain Energy Company, 1981)

Figure 8. Location map of estimated strippable reserves,

Black Butte coal deposit, Sweetwater County

Wyoming (from Rocky Mountain Energy Company, 1982)

Figure 9. Approximate stratigraphic position and nomenclature for coal beds in the Almond Formation, Salt Wells strippable deposit, Green River Coal Field (modified from Roehler, 1979 a-c)

Figure 10. Location of estimated strippable reserves, Salt Wells

coal deposit, Sweetwater County, Wyoming

(from Rocky Mountain Energy Company, 1982) 
1. Summary. The remaining demonstrated reserve base (DRB) of strippable coal in the above seven deposits totals about 1.8 billion short tons (Table 1). Coals in these deposits occur in the Late Cretaceous Mesaverde Formation (or Group), and the Lance Formation; the Paleocene Fort Union Formation; and the Eocene Wasatch Formation. The Mesaverde is a group where it can be subdivided into separate formations. Of this total, almost 0.69 billion tons (38 percent) occurs in the Wasatch Formation of the Red Desert coal deposit and about 0.66 billion tons (36 percent) occurs in the Fort Union Formation in four of the coal deposits.

All but 145.8 million tons of the 1.8 billion tons of strippable coal has a heating value of 15.00 - 19.99 million Btu/short ton. Coal with a heating value of less than 15.00 million

Table 1. Summary of remaining demonstrated reserve base (DRB) of etrippable coal deposits in the Greon River Coal Field, Wyoming, through December 31, 1990 (in million short tons).

\begin{tabular}{|c|c|c|c|c|c|c|c|c|}
\hline \multirow[b]{2}{*}{ Coal Beda } & \multirow{2}{*}{$\begin{array}{l}\text { Btu Content } \\
\text { million BTU/ } \\
\text { short ton }\end{array}$} & \multicolumn{6}{|c|}{ sulfur content (lbse sulfur/million Btu) } & \multirow{2}{*}{$\begin{array}{c}\text { Total } \\
\text { all sulfur } \\
\text { Categories }\end{array}$} \\
\hline & & $\sum 0.40$ & $0.41-0.60$ & $0.61-0.83$ & $0.84-1.67$ & $1.68-2.50$ & $>2.50$ & \\
\hline \multicolumn{9}{|c|}{ Red Desert Deposit } \\
\hline $\begin{array}{l}\text { Wasatch Fm. coals } \\
\text { Hadsell } 2\end{array}$ & $<15.00$ & --- & $-a-$ & $-\cdots$ & & --- & & \\
\hline Battle $2 \& 3$ & $15.00-19.99$ & -- & --- & $-\infty$ & --- & 38.10 & -39.80 & $\begin{array}{l}39.80 \\
38.10\end{array}$ \\
\hline Sourdough, Monument, \& Terney & $15.00-19.99$ & --- & $-\infty$ & --- & -- & --- & 458.90 & 458.90 \\
\hline Croston $2 \& 3$ & $15.00-19.99$ & --- & --- & --- & $-\infty$ & -- & 125.60 & 125.60 \\
\hline Latham 344 & $15.00-19.99$ & -- & -- & -- & -- & -- & 70.70 & 70.70 \\
\hline Subtotal all beds & $\begin{array}{l}<15.00 \\
15.00-19.99\end{array}$ & $\overline{--n}$ & $=-$ & $\overline{---}$ & $=-$ & $-\overline{38.10}$ & $\begin{array}{r}39.80 \\
655.20\end{array}$ & $\begin{array}{r}39.80 \\
693.30\end{array}$ \\
\hline \multicolumn{9}{|c|}{ Creston-Cherokeo Deposit } \\
\hline $\begin{array}{l}\text { Cherokee B\&C (Fort Union Fm.) } \\
\text { Other Fort Union Fm. coals }\end{array}$ & $\begin{array}{l}15.00-19.99 \\
15.00-19.99 \\
\end{array}$ & --- & -- & -- & --- & $\begin{array}{l}200.90 \\
159.10 \\
\end{array}$ & $\overline{--}$ & $\begin{array}{l}200.90 \\
159.10 \\
\end{array}$ \\
\hline Subtotal all beds & $15.00-19.99$ & --- & -- & --- & --- & 360.00 & --- & 360.00 \\
\hline \multicolumn{9}{|c|}{ Northern Little Snake River Deposit } \\
\hline $\begin{array}{l}\text { Lance \& Fort Union Fm. coals } \\
\text { Mesaverde Fm. coals }\end{array}$ & $\begin{array}{l}15.00-19.99 \\
20.00-22.99\end{array}$ & $\ddot{--}$ & 223.60 & $-\overline{46.00}$ & $\overline{--}$ & $\overline{--}$ & $\overline{---}$ & $\begin{array}{r}223.60 \\
46.00\end{array}$ \\
\hline \multicolumn{9}{|c|}{ Jim Bridger Deposit } \\
\hline Deadman coals (Fon Union Fm.) & $15.00-19.99$ & --- & -- & 151.20 & -- & --- & --- & 151.20 \\
\hline \multicolumn{9}{|c|}{ Loucite Hilles Deposit } \\
\hline Almond Fm. coals & $15.00-19.99$ & --- & 162.20 & --- & --- & --- & --- & 162.20 \\
\hline \multicolumn{9}{|c|}{ Black Butte Doposit } \\
\hline Almond Fm. coals & $15.00-19.99$ & --- & 15.40 & $-\overline{36.00}$ & $\ddot{---}$ & $=-$ & $=-$ & $\begin{array}{l}15.40 \\
36.00\end{array}$ \\
\hline $\begin{array}{l}\text { Lance Fm. coals } \\
\text { Fort Union Fm. coals }\end{array}$ & $\begin{array}{l}15.00-19.99 \\
15.00-19.99\end{array}$ & $\overline{--}$ & $-\overline{37.10}$ & $-\infty$ & --- & -- & -- & $\begin{array}{l}38.00 \\
37.10\end{array}$ \\
\hline $\begin{array}{l}\text { Fort Union Fm. coais } \\
\text { Subtotal all beds }\end{array}$ & $\frac{15.00-19.99}{15.00-19.99}$ & --- & 52.50 & 36.00 & -- & -- & --- & $\frac{31.10}{88.50}$ \\
\hline \multicolumn{9}{|c|}{ Sak Wollo Deposit } \\
\hline Almond Fm. coals & $20.00-22.99$ & -- & 60.00 & -- & -- & -- & -- & 60.00 \\
\hline \multicolumn{9}{|c|}{ Summary all deposita } \\
\hline Subtotal all coal beds & $\begin{array}{c}<15.00 \\
15.00-19.99 \\
20.99-22.99 \\
\end{array}$ & $\begin{array}{l}--- \\
--- \\
---\end{array}$ & $\begin{array}{r}--\overline{438.30} \\
60.00 \\
\end{array}$ & $\begin{array}{r}187.20 \\
46.00 \\
\end{array}$ & $\begin{array}{l}--- \\
--- \\
---\end{array}$ & $\begin{array}{l}--- \\
398.10 \\
---\end{array}$ & $\begin{array}{r}39.80 \\
655.20 \\
0.00 \\
\end{array}$ & $\begin{array}{r}39.80 \\
1,678.80 \\
106.00 \\
\end{array}$ \\
\hline Total all sulfur categories & & --- & 498.30 & 233.20 & $-\infty-$ & 398.10 & 695.00 & $1,824.60$ \\
\hline
\end{tabular}


Btu/short ton occurs in the Wasatch Formation of the Red Desert deposit. Coal with a heating value of $20.00-22.99$ occurs in the Mesaverde Formation (or Group) in the Northern Little Snake River and Salt Wells deposits.

Strippable coal with the lowest sulfur content in the Green River Coal Field (0.41 - $0.60 \mathrm{lbs}$ sulfur/million Btu) occurs in four of the seven deposits and accounts for 27 percent of the total strippable coal in the field. Coals with sulfur contents greater than $1.68 \mathrm{lbs}$ sulfur/million Btu occur in the Red Desert and Creston-Cherokee deposits and account for nearly 60 percent of the 1.8 billion tons of strippable coal.

Significant amounts of coal have been produced from only the Jim Bridger, Leucite Hills, and Black Butte strippable deposits. The remaining four coal deposits still contain the original DRB; therefore, no adjustments for production and mining losses are necessary for these deposits. A total of 161.7 million tons of coal has been depleted from the original strippable DRB through mining and production losses. Most of the depleted coal has been mined from deposits that contain low-sulfur coal reserves.

2. Methodology and assumptions. Original strippable DRB tonnages were taken from Smith and others (1972) and Glass (1981). Although some new coal resource estimates for additional strippable deposits in this coal field have been published since the above two reports, inclusion of new resource calculations was beyond the scope of this report. However, some coal quality data given in these new resource estimates were used to characterize the coal quality in some of the deposits discussed in this report.

The original DRB for the Jim Bridger, Leucite Hills, and Black Butte strippable coal deposits required tonnage adjustments for mining and production losses. Although some coal was produced in several other strippable deposits in this coal field, the tonnage was not significant and did not affect the DRB. A recovery factor of 90 percent was used for both the Jim Bridger and Black Butte deposits and a recovery factor of 85 percent was used for the Leucite Hills deposit. A 90-percent recovery factor means that 90 percent of the total coal in-place was recovered, and that 10 percent of the coal in-place was not recovered because of mining losses and other inefficiencies. 
3. Analyses. Coal analyses used in this report were taken from various published and unpublished sources (Tables 2 through 8 ). Whenever possible, analyses from within a coal deposit were used to assign coal quality categories to the DRB. In some cases, however, analyses of nearby coal beds were used to characterize the strippable deposit. Analyses from 2,873 core, channel and tipple samples and about 308 coal deliveries were examined for these strippable deposits. A discussion of the coal analyses used in each area is included in the reports on individual deposits (below).

All analyses were evaluated on an individual basis where appropriate. Analyses from poorly located data points were not used. Analyses with anomalously low heating values due to weathering or high ash content were also not used. Where only partial thicknesses of a coal bed were sampled and analyzed and no other information was available nearby, the data were not considered representative of the entire coal bed and were not used in this study. Where only partial thicknesses of a coal bed were sampled and analyzed and there was other information on coal thickness and quality (of complete coal beds) available nearby, the analyses were weighted by linear footage sampled.

4. Red Desert deposit. The remaining demonstrated reserve base (DRB) of strippable coal in this deposit is 733.1 million short tons (Table 1). Because no coal has been mined in this deposit, the original strippable DRB (Smith and others, 1972) is also the remaining strippable DRB. Coal beds 5 feet or more in thickness and separated by not more than 120 feet of interburden were considered strippable. Two or more coal beds (each 5 feet thick or more) in the same stratigraphic section and separated by less than 120 feet of interburden, were also considered strippable if the depth to the uppermost coal bed was 120 feet or less. Strippable coal beds in the Eocene Wasatch Formation (Figures 1 and 2) are relatively high in sulfur and low in heating value: only 38.1 million tons of the total strippable DRB contains less than $2.50 \mathrm{lbs}$ sulfur/million Btu; all of the DRB contains less than 19.99 million Btu/short ton (Table 1).

Analytical data for coal beds that comprise the strippable DRB were taken from published analyses of coal cores (Pipiringos, 1961, and Masursky, 1962). The Tierney coal bed(s) mentioned in Table 1 as part of the Sourdough, Monument and Tierney group of coal beds are western equivalents of some of the Sourdough beds in this area. Several coal beds that contained analytical data were not used in the DRB calculations because the beds were not of sufficient thickness. A weighted average for each coal bed was determined on the basis of linear fontage sampled (Table 2). Fach coal bed( $s$ ) was then 

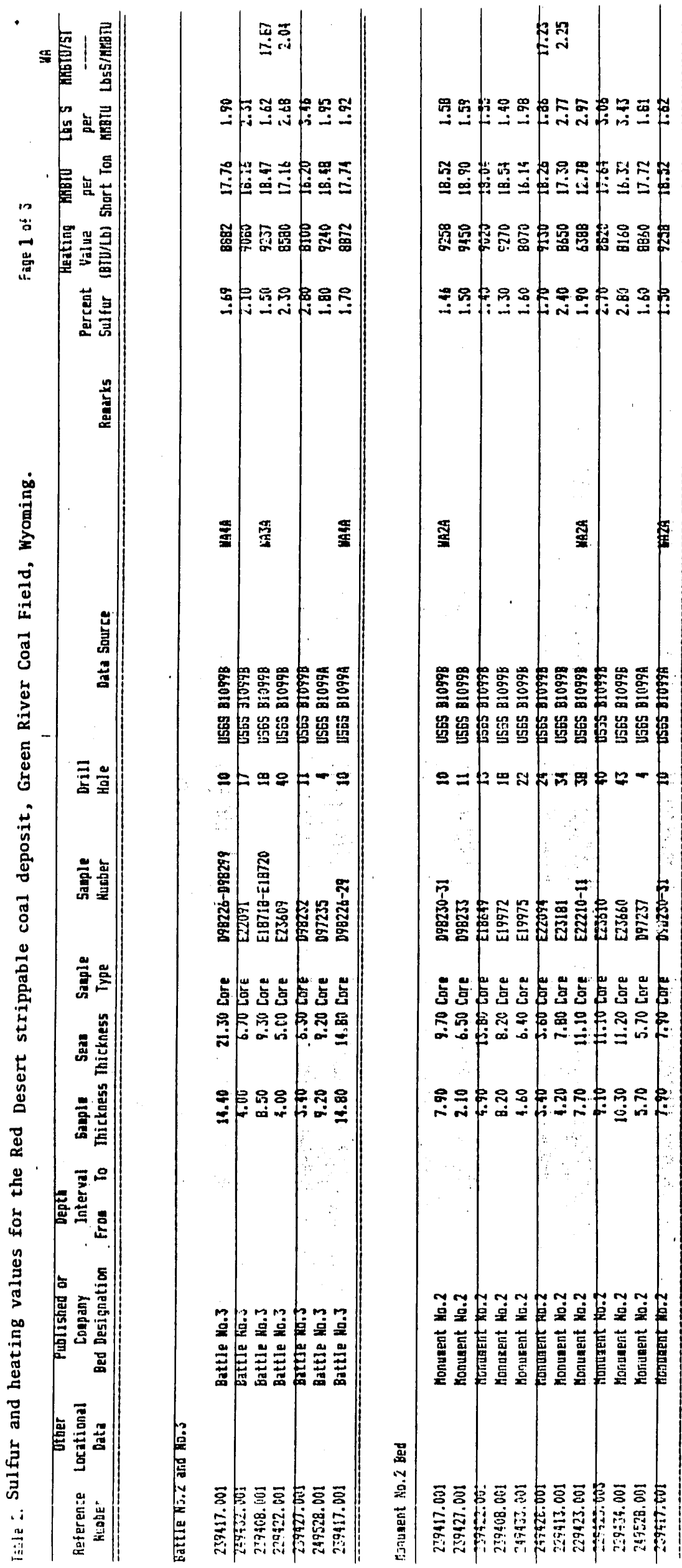

|

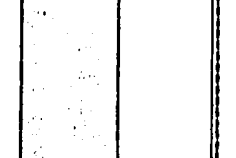

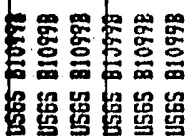

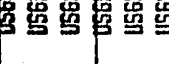

$F=\pi x$

可的

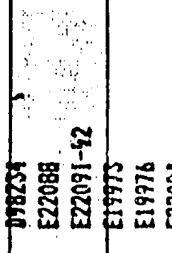

.

总总芦总

웅요응

- -

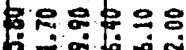

善害器

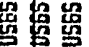

r-ada

器高喜

总莺总

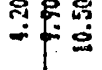

웅윰웅

E-7 


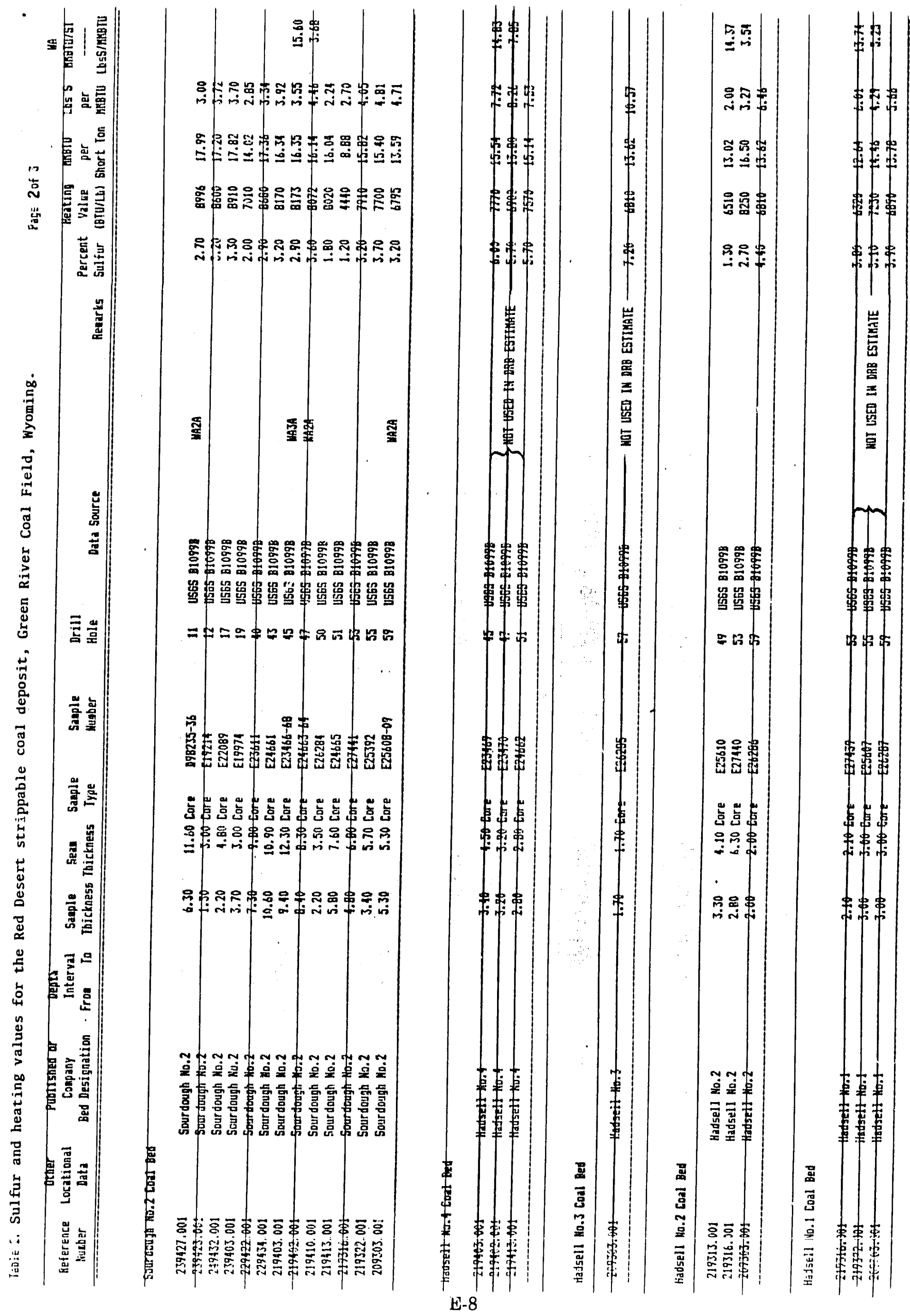




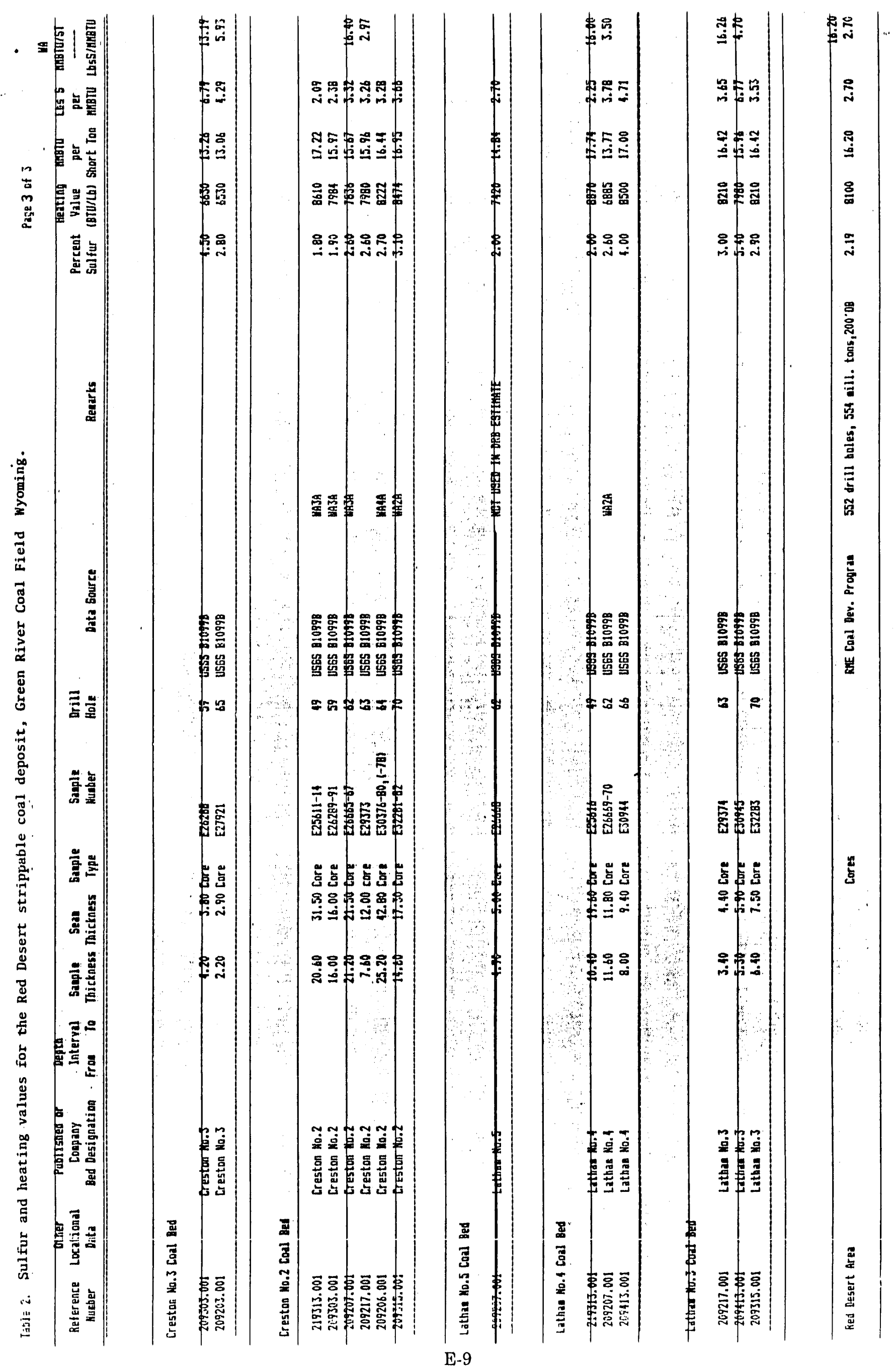




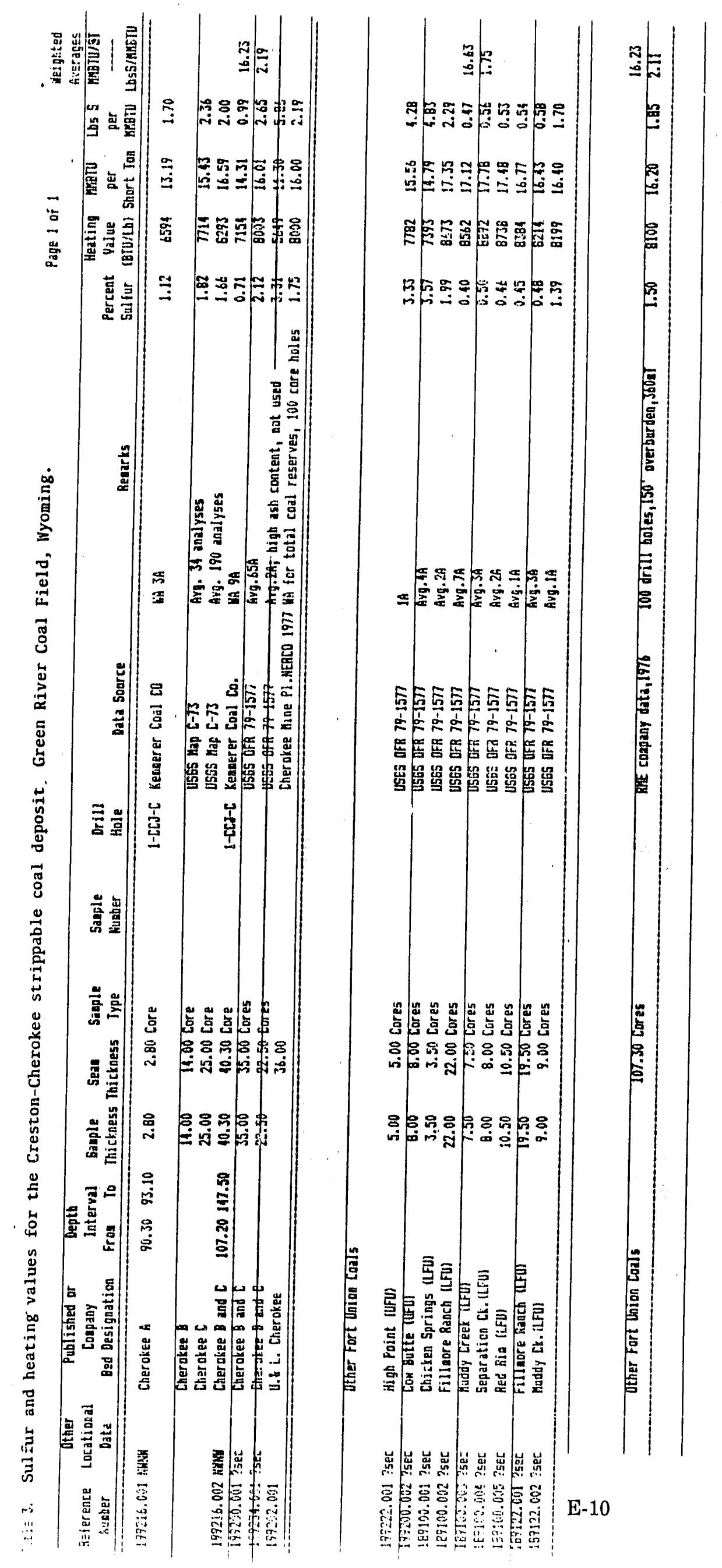




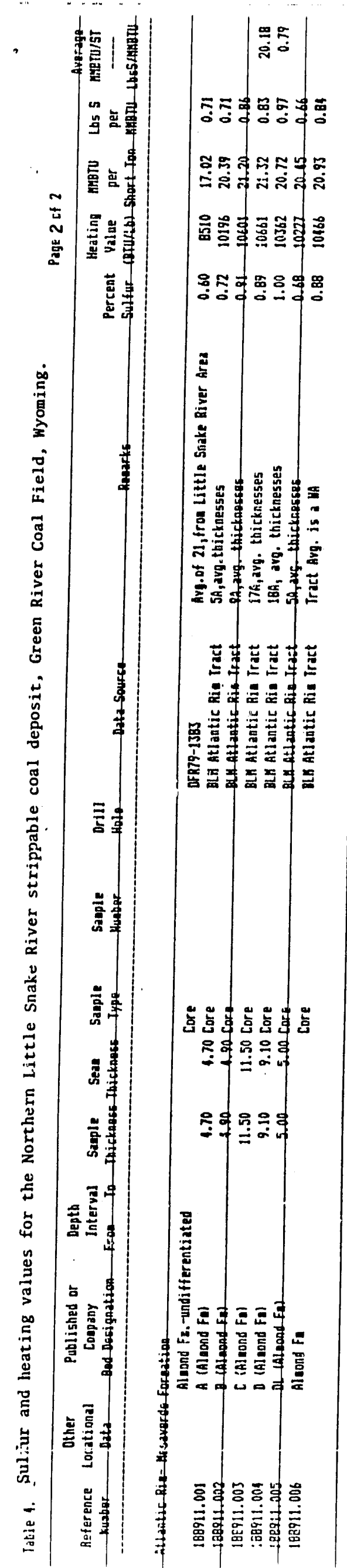

E-12 


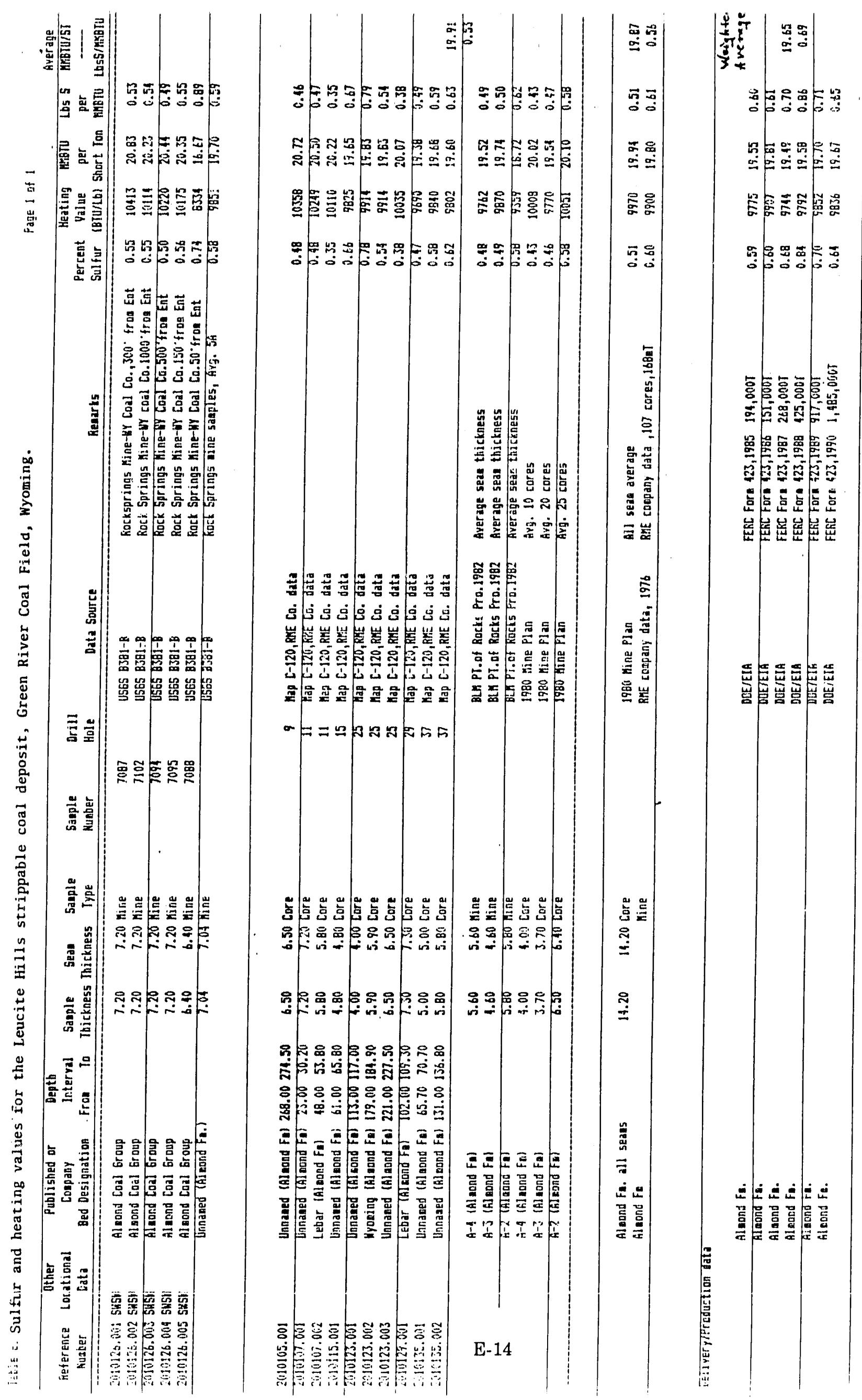




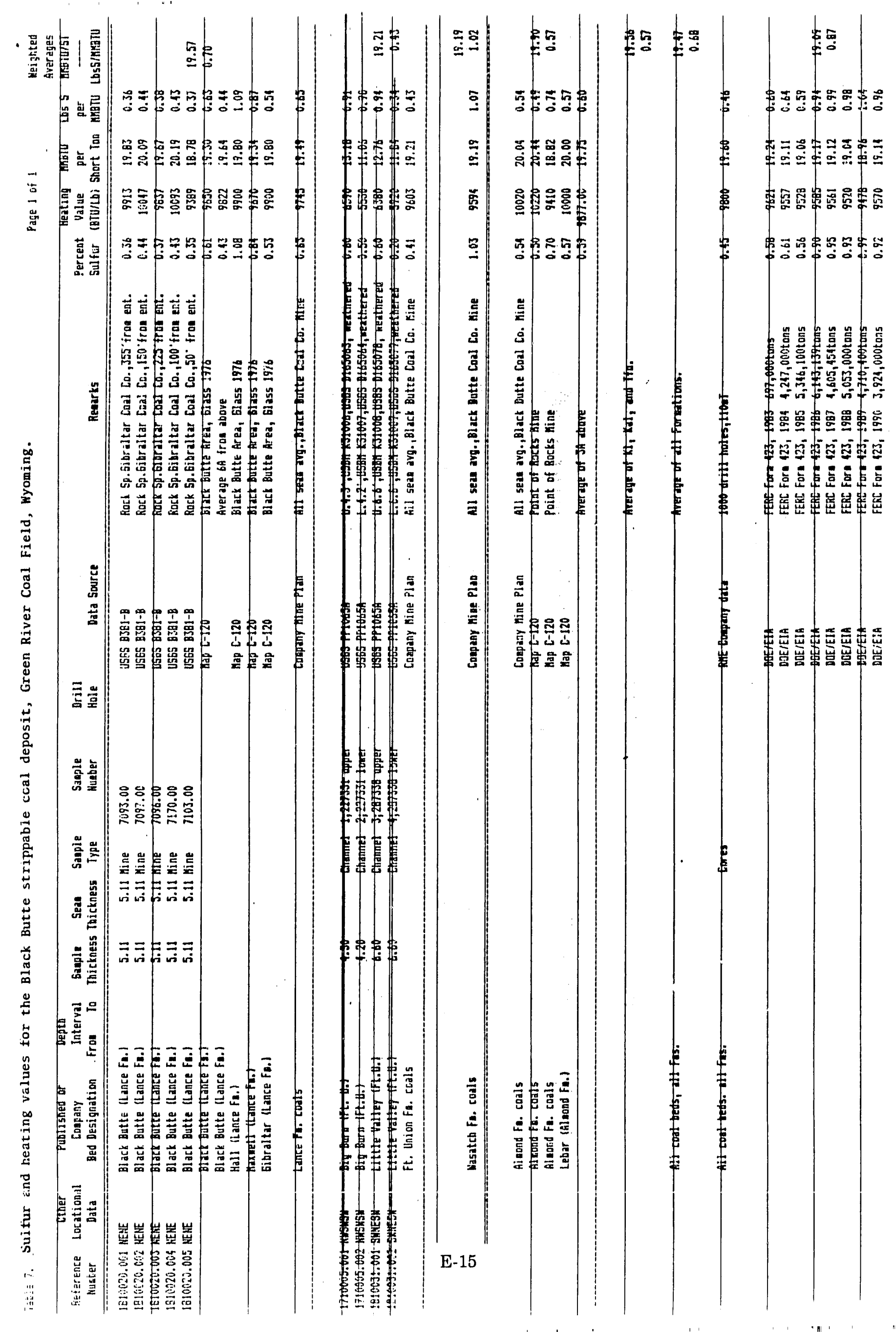




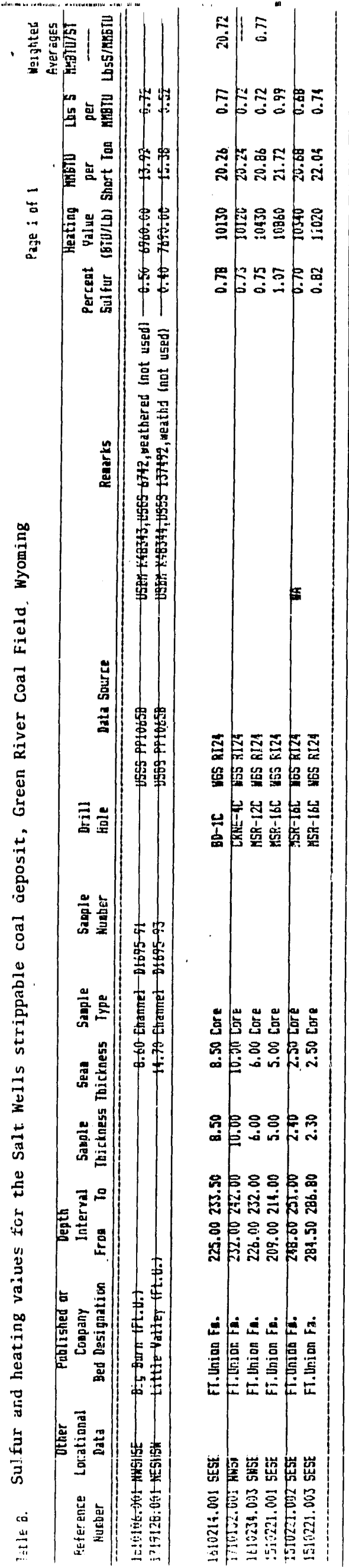

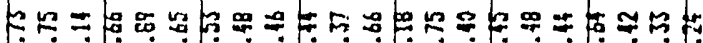
En

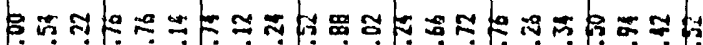

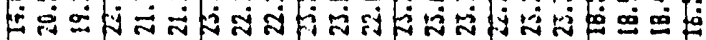

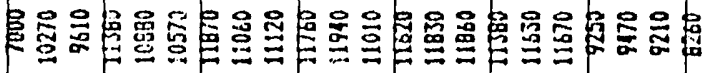

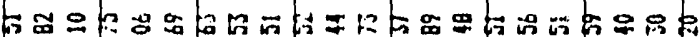

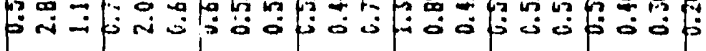

菖

渵

屈

点

呞

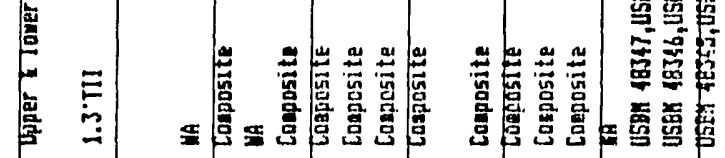

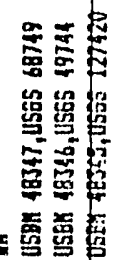

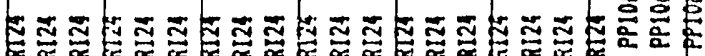

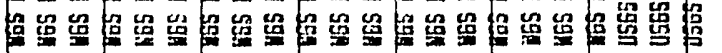

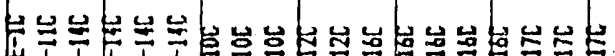

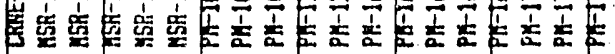

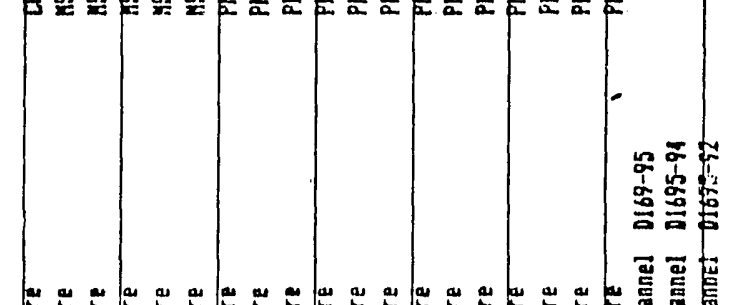

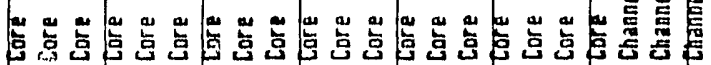

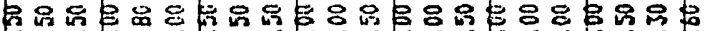

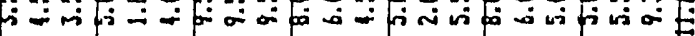

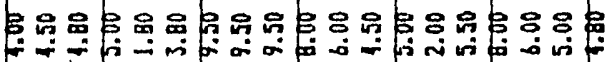

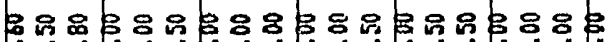

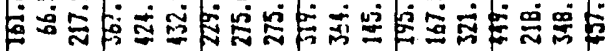

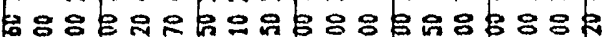

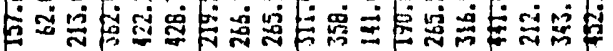

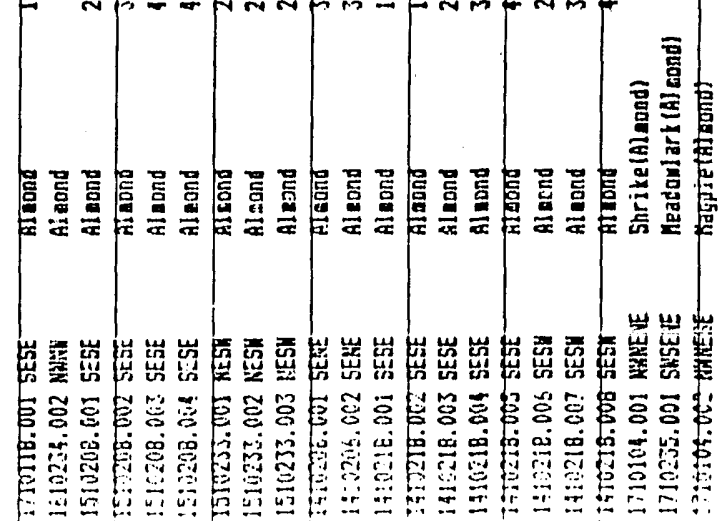




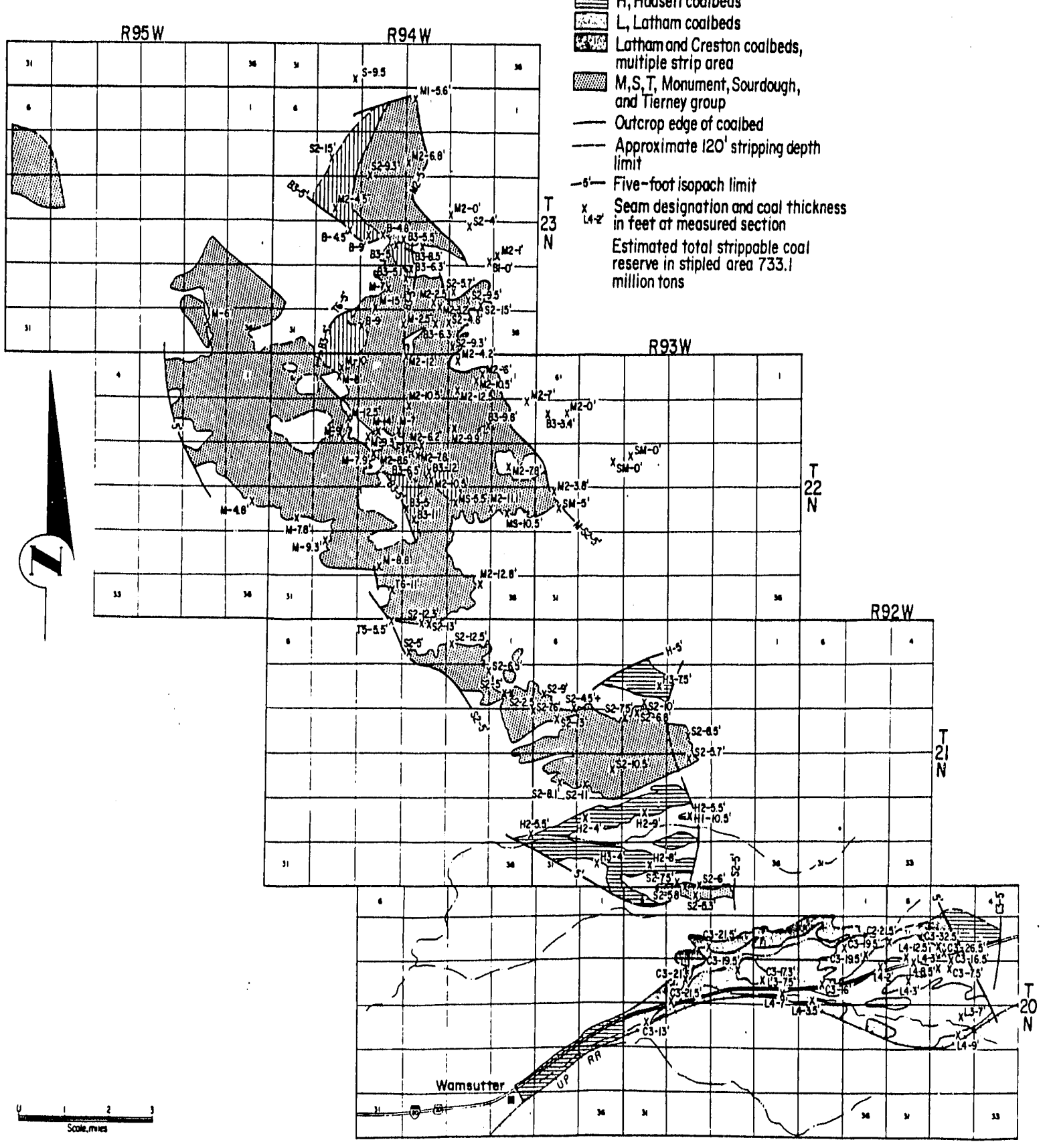

Figure 1. Location map of estimated strippable reserves, Red Desert coal deposit, Great Divide Basin area. (From

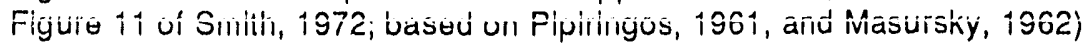




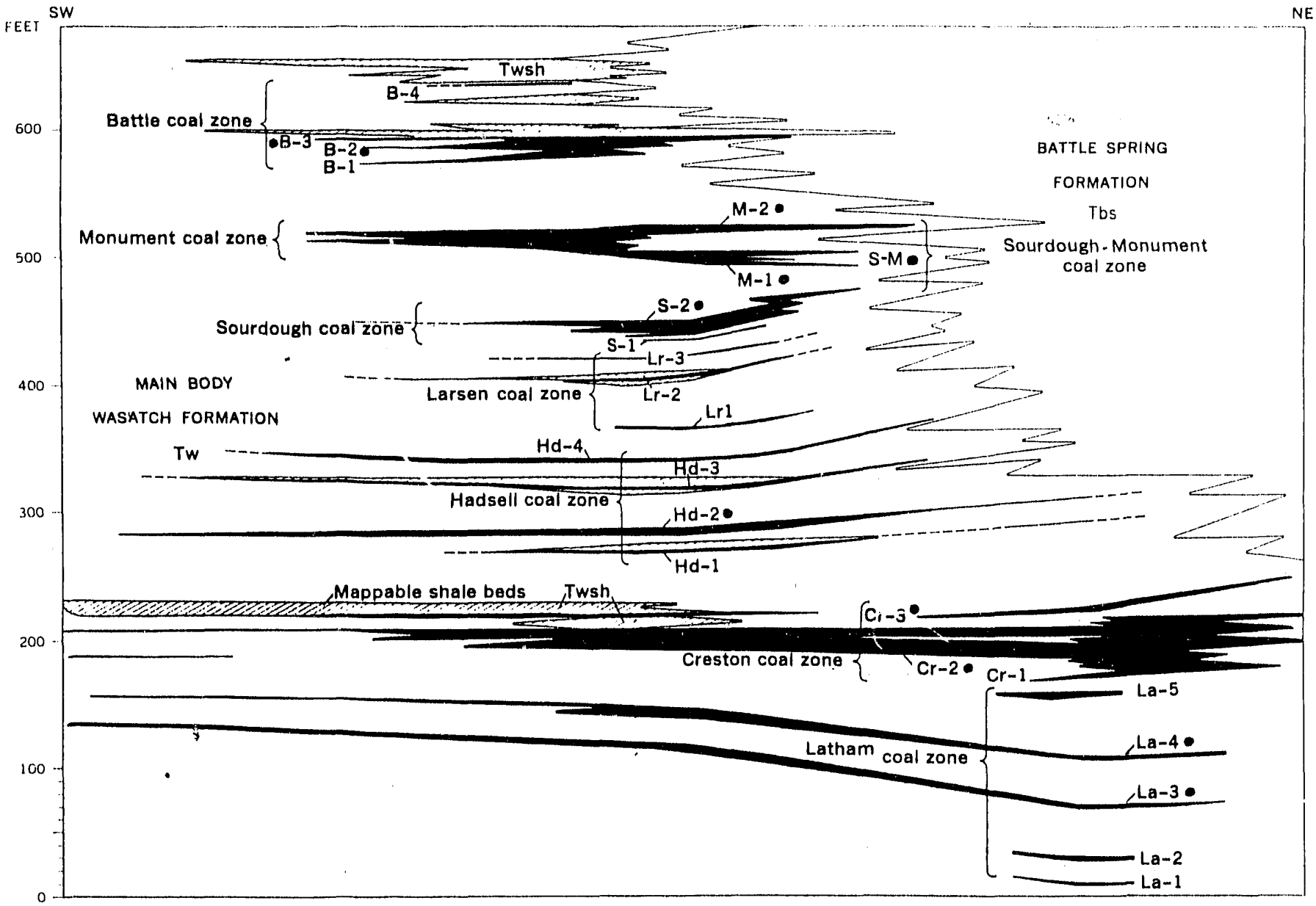

COMPOSITE RESTORED SECTION SHOWING LITHOFACIES AND PRINCIPAL COAL BEDS IN THE EASTERN RED DESERT AREA

Figure 2. Approximate stratigraphic position and correlaiton of coal beds and coal zones in the Red Desert strippable

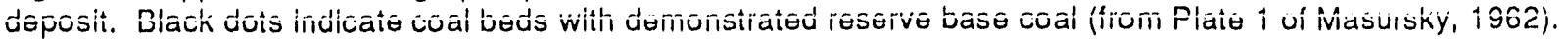


assigned an appropriate sulfur and heating value category; the amount of reserves in each coal bed(s) was taken from Smith (1972).

This deposit contains Rocky Mountain Energy Company's 554-million ton Red Desert exploration and development project. Analytical data from a 552-hole coal drilling and sampling program on this project indicates that the coal has an average sulfur content of $2.70 \mathrm{lbs}$ sulfur/million Btu and a heating value of 16.20 million Btu/ short ton. The coal analyses in this project area fall into the same sulfur and heating value categories as most of the coal samples collected by Pipiringos (1961) and Masursky (1962) and serve to verify the analytical data presented by those two authors.

5. Creston-Cherokee deposit. This deposit contains a remaining strippable DRB of 360 million short tons of coal (Table 1). Because no coal has been mined from this deposit, the original strippable $\mathrm{DRB}$ is also the remaining $\mathrm{DRB}$. At least 4 strippable coal beds occur in the area (Figures 3 and 4 ). All the coals occur in the upper coal zone of the Fort Union Formation. The Cherokee B and C coal beds contain 200.9 million tons of DRB coal (Smith and others, 1972). After subtracting the resources in the Cherokee $B$ and $C$ coals from the 360 million tons of DRB coal ^ sported by Glass (1981) for the entire area, the remaining 159.1 million tons of coal were assigned to the Cow Butte and Horse Butte coal beds.

The Cherokee $\mathrm{B}$ and $\mathrm{C}$ coal beds merge into a single, thick coal bed that averages 35.5 feet thick in the southwestern part of the area. Interburden where the two beds are separated can be up to 100 feet in the northwestern part of the area. Maximum overburden for the strippable area of the Cherokee coal beds is 140 feet. The Cow Butte and Horse Butte coal beds are up to 15 and 20 feet thick, respectively, and occur primarily in the eastern and northern parts of the area. Strippable coal for these two beds occurs where the overburden is less than 120 feet thick.

Analytical data from 499 analyses in the area (summarized in Table 3) show that the Cherokee coal beds contain about $2.19 \mathrm{lbs}$ sulfur/million Btu and the other Fort Union coal beds contain about $1.75 \mathrm{lbs}$ sulfur/million Btu. Sulfur contents and heating values for both the Cherokee and the other Fort Union coal beds, as well as averages for all coal beds in the deposit, are in the 15.00-19.99 million Btu/short ton category for heating content and in the 1.68-2.50 lbs sulfur/million Btu category for sulfur content. The Creston-Cherokee area contains almost 20 percent of the remaining strinnable coal in the Green River Coal Field. 


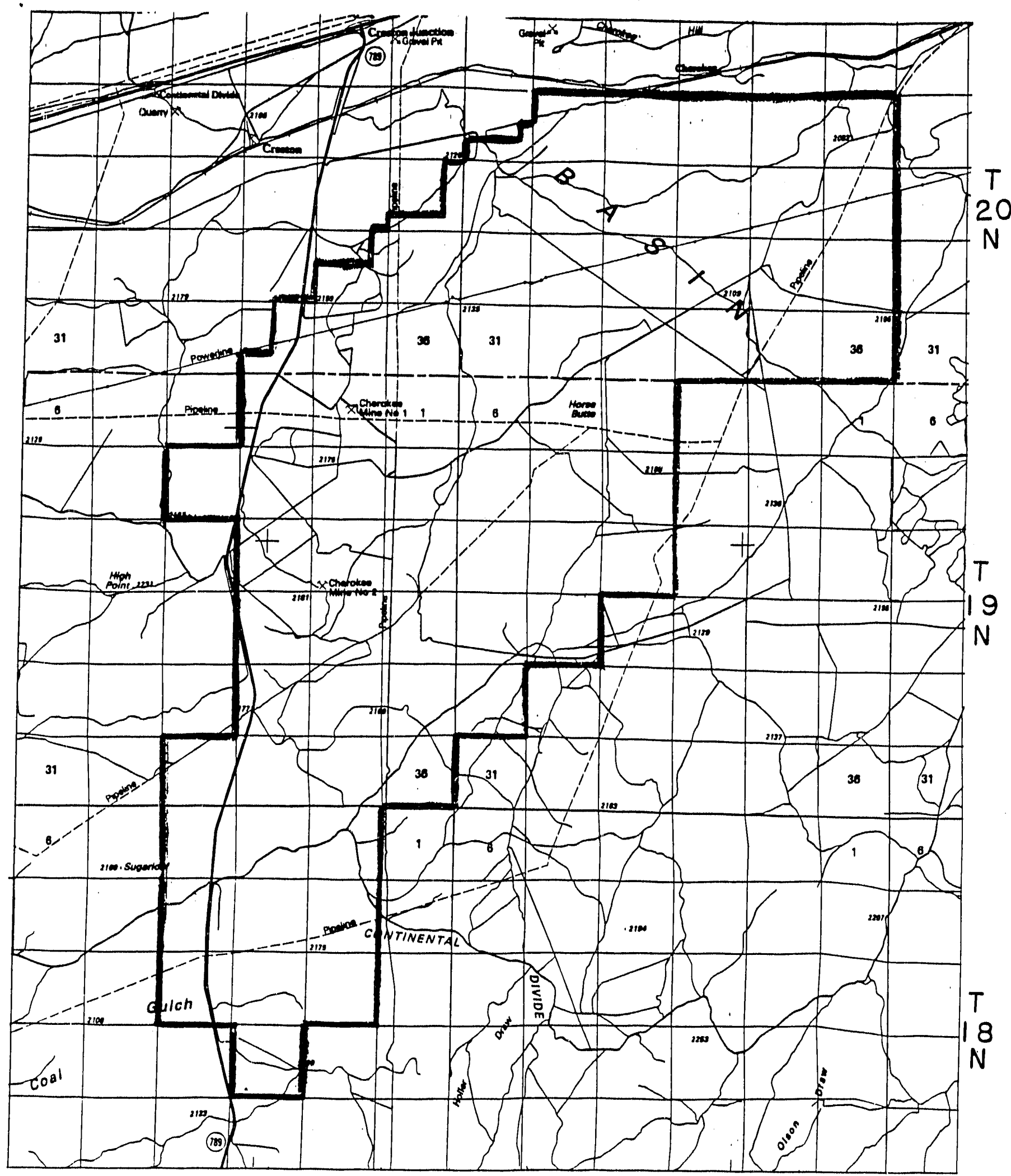

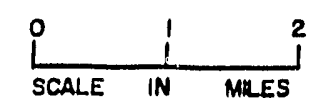

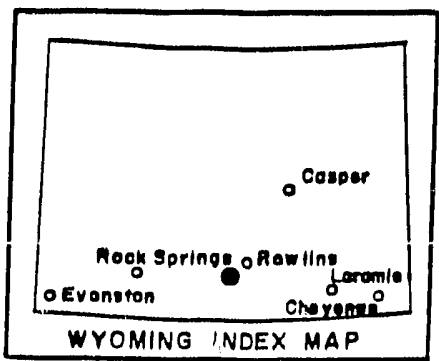

W YOMING INDEX MAP
Figure 3. Map showing location of estimated strippable reserves, Creston-Cherokee coal deposit, Sweetwater and Carbon Counties, Wyoming (outline from Rocky Mountain Energy Company, $i \overline{9} 7 \overline{6})$.

E-20 


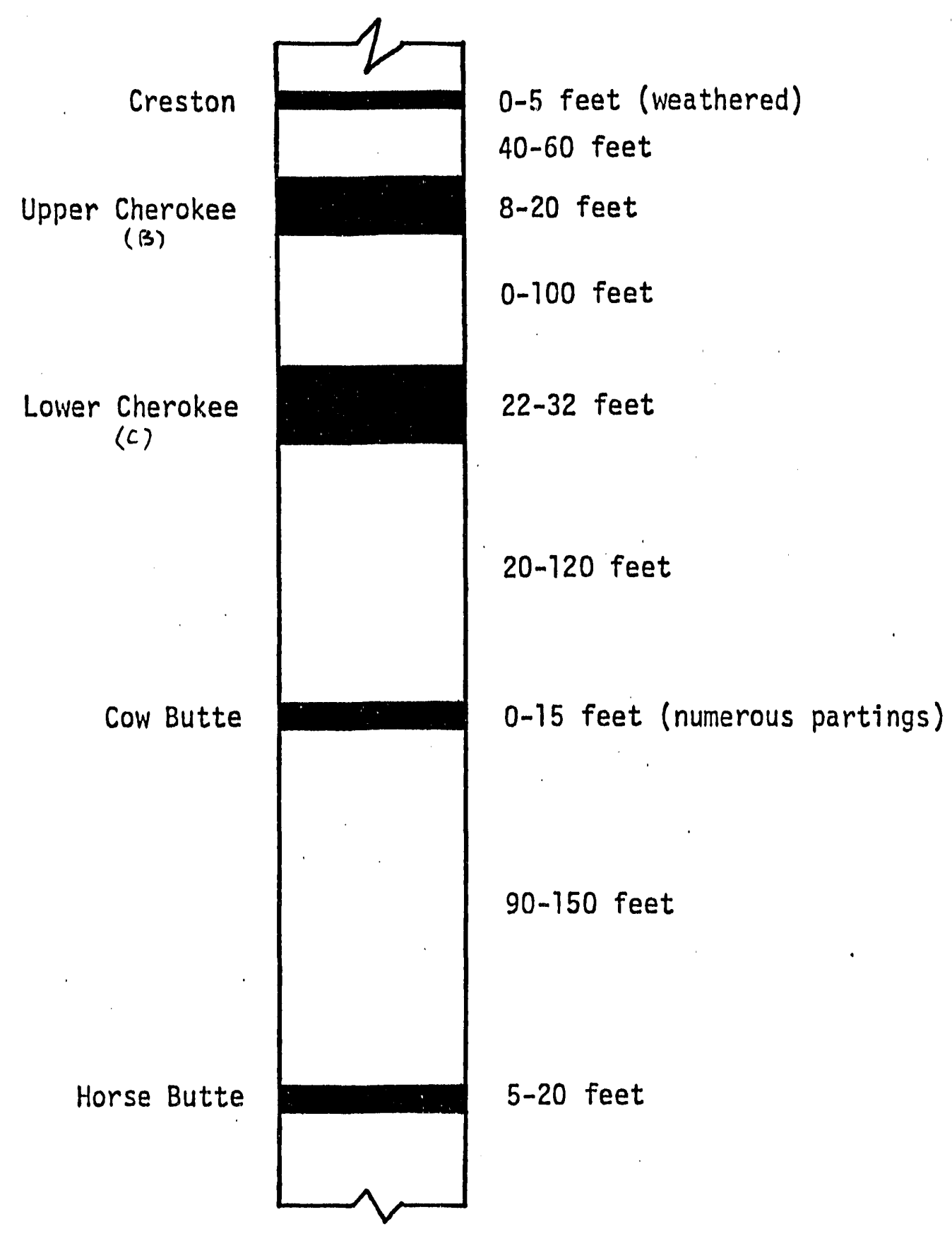

Figure 4. Stratigraphic column of the Cherokee and other Fort Union Formation coal beds, Creston-Cherokee strippable coal deposit, Green River Coal Fleld, Wyoming (from Northern Energy Resources Company, 1977a). 
6. Northern Little Snake River deposit. This deposit contains 223.3 million tons of remaining strippable DRB coal in the Lance and Fort Union Formations and about 46 million tons of remaining strippable coal in the Mesaverde Formation [or Almond Formation of the Mesaverde Group] (Table 1). Because no significant coal mining has occurred in this deposit, the total original DRB of 269.6 million short tons (Glass, 1981) is also the renaining DiRB.

Most of the Fort Union Formation coals occur in the China Butte and Red Rim proposed mine areas (Figure 5). The coal beds occur in the lower coal zone of the Fort Union and are separated from the upper coal zone in the Creston-Cherokee area to the west by a middle non-coaly interval about 1,200 feet thick. The lower coal zone of the Fort Union is 1,400 to 1,500 feet thick and contains numerous minable coal beds. Correlations of coal beds and the current coal bed nomenclature for coal beds in the lower coal zone of the Fort Union in this area is given in Honey and Hettinger (1989). Coal bed designations used in the present report for the China Butte and Red Rim areas are those used by industry and may not follow those of Honey and Hettinger (1989).

In the China Butte area, six coal beds contain strippable resources. These coal beds are designated $\mathrm{A}, \mathrm{B}, \mathrm{C}, \mathrm{D}, \mathrm{C} 1$, and $\mathrm{F}$ in descending stratigraphic order. The average thicknesses of these coal beds are 4.6, 26.4, 8.6, 8.1, 8.1, and 9.5 feet respectively; the maximum overburden (or interburden)-to-coal ratio for a single, strippable coal coal bed is five to one, unless the maximum highwall height of 150 feet is reached first.

In the Red Rim area, as many as 12 coal beds are considered economically minable and are designated, in descending stratigraphic order, $B_{1}, B_{2}, C, D, R_{1}, R_{2}, E, R_{3}, F$, Pine, $\mathrm{G}$, and $\mathrm{H}$. The four thickest, most continuous coal beds are the F, G, B, and Pine, which average $15,12,11.3$, and 10.1 feet thick, respectively. The maximum mining depth for strippable coal in this area is 150 feet or a 10:1 stripping ratio, whichever is reached first (Wyoming Department of Environmental Quality and U.S. Office of Surface Mining Reclamation and Enforcement, 1983).

Strippable coals in the Almond Formation of the Mesaverde Group are loca' e 1 in the Atlantic Rim proposed mine area (Figure 5). Coal beds in this area are designived A, B, $C, D$, and $D_{1}$, and range in thickness from 3.0 to 9.5 feet. Maximum overburden (or interburden)-to-coal ratio for a single, strippable coal bed is five to one, unless a maximum final highwall height of 150 feet is reached first. Correlations of the Almond Formation coals at Atlantic Rim with other areas or deposits have not been established 
Strippable coals in the Lance Formation account for only a small portion of the total coal resources in this deposit and are included with those resources in the Fort Union Formation. A single coal analysis for the Lance Formation in this area was not considered indicative of the coal in the entire formation, so this analysis was used in characterizing the Fort Union Formation coal. Strippable Lance Formation coal beds occur between the China Butte and the Atlantic Rim areas, as well as east of the Red Rim area, between the overlying Fort Union Formation and the underlying Lewis Shale. Coal thicknesses in the Lance probably do not exceed 10 feet and strippable coal is probably not above an overburden-to-coal ratio of five to one.

Some 429 coal analyses for individual coal beds were available for this deposit (Table 4 summarizes this data). Because the analytical data consists of average coal quality for each coal bed in a particular project area, average (instead of weighted average) quality for all coal beds was used in assigning coal quality categories to the reserves. The average heating value for combined Lance and Fort Union coal beds is $17.51 \mathrm{million}$ Btu/short ton and the average sulfur content is $0.59 \mathrm{lbs}$ sulfur/million Btu. Mesaverde Formation coals have slightly higher heat contents (20.14 million Btu/short ton) and slightly higher sulfur contents $(0.79 \mathrm{lbs}$ suifur/million Btu) than the Lance and Fort Union coals.

7. Jim Bridger deposit. This deposit contains 151.2 million tons of remaining strippable DRB coal in the Deadman coal beds of the Fort Union Formation (Table 1). As many as five strippable coal beds in the Deadman coal zone of the lower Fort Union Formation coalesce into a single coal bed over 30 feet thick in the Jim Bridger mine. At least some of the coal beds in this deposit correlate with the Little Valley coal beds in the Black Butte area to the south (Glass, 1981). Strippable coal is found under less than 200 feet of overburden in this deposit. Original strippable resources of 250 million tons in this deposit (Figure 6) have been depleted by 98.8 million tons through coal production and mining losses. Cumulative coal production through 1990 was about 88.9 million tons; mining and production losses, using a 90 percent recovery factor, accounted for 9.8 million tons.

About 168 coal analyses, including 96 coal deliveries from 1983 through 1990, were used to categorize the reserves (T'able 5 summarizes the data). Weighted average sulfur and Btu contents, based on linear footages of sampled coal beds, were calculated at 18.89 million Btu/short ton and $0.63 \mathrm{lbs}$ sulfur/million Btu respectively. Weighted averages 

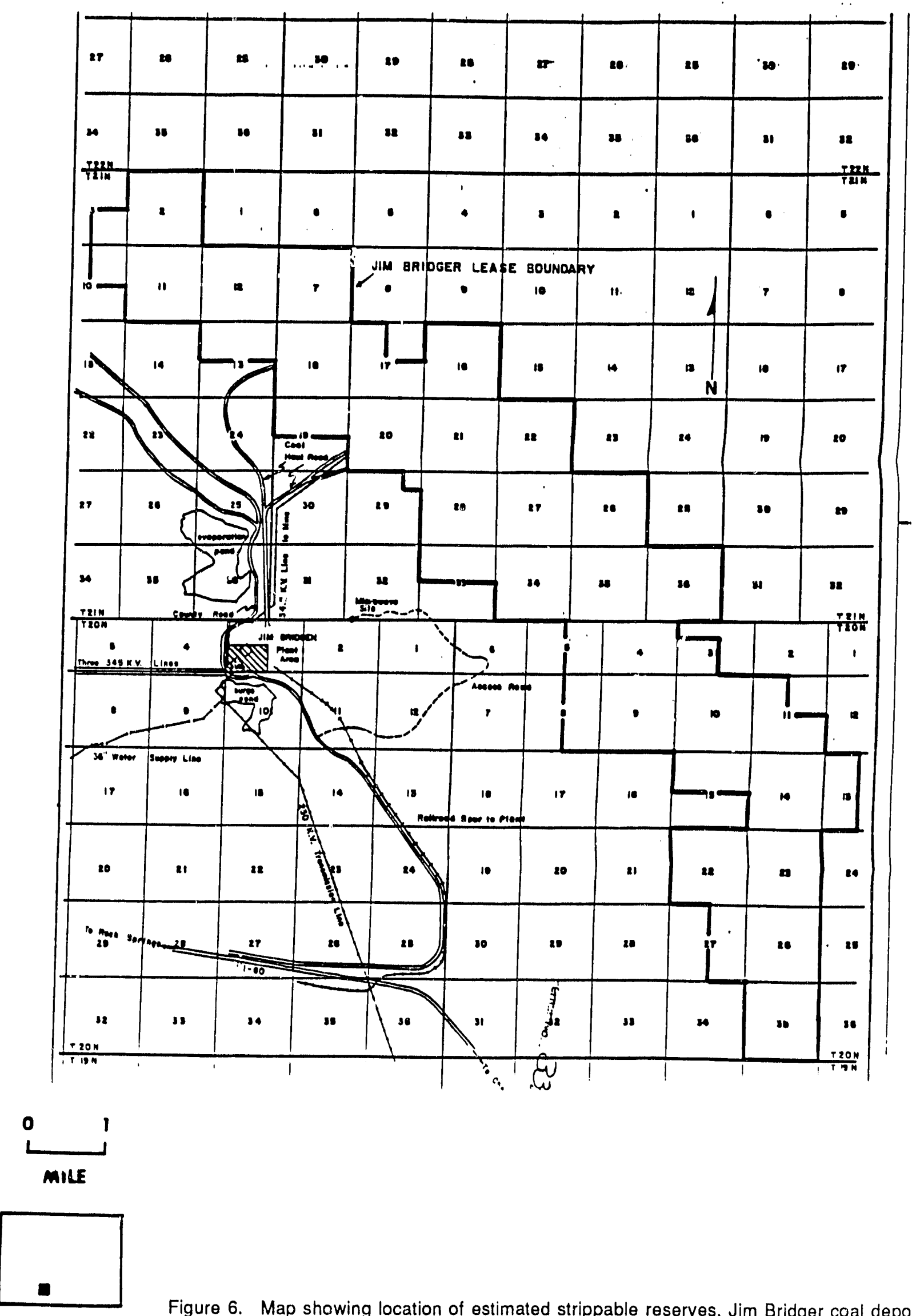

พัพróminvō

Figure 6. Map showing location of estimated strippable reserves, Jim Bridger coal deposit, Sweetwater County, Wyoming (trom Northern Energy Resources Company, 1977b). 
based on tonnages of delivered coal were very similar to the weighted averages based on sampled coals. All coal in the deposit was therefore assigned to a single heating value category and a single sulfur category.

8. Leucite Hills deposit. The remaining strippable DRB for this deposit is 162.2 million short tons of coal (Table 1). The original strippable DRB assigned to this deposit (Glass, 1983) included both Fort Union Formation and Almond Formation coal beds but the location map of the deposit (Figure 7) indicates that only coal beds in the Almond Formation are present in this deposit. Coal resources in the Fort Union Formation occur to the east of the Leucite Hills and are part of the adjacent Jim Bridger strippable deposit (described above). The Leucite Hills deposit contained an original strippable DRB of 168 million tons. Cumulative total coal production of 4.9 million tons plus mining losses of 0.7 million tons (based on a recovery factor of 85 percent) have depleted the original DRB by about 5.8 million tons.

The Almond Formation of the Mesaverde Group contains five coal beds in the Leucite Hills area. None of these coal beds have been correlated with other areas or deposits. Three of these beds, the A2, A3, and A4, are of minable thickness (over 2.5 feet thick). The A2, A3, and A4 coal beds average 6.5, 3.7, and 4.0 feet thick, respectively, within the deposit. The maximum overburden-to-coal ratio for strippable coal in this deposit is estimated at 10 to 1 , or a final highwall for all three coal beds (combined) of about 150 feet.

Analytical data were available from 247 coal analyses (summarized in Table 6), including quality data from 72 coal deliveries from 1985 through 1990 . Because of the number of different coal beds in this deposit, an average (not a weighted average) heating value and sulfur content was calculated for the deposit. This average is very close to two averages for the entire deposit reported in a mine plan for the area and from other company data. Although a weighted average based on delivered tonnages placed the coal in a higher sulfur content category than the category determined from coal core analyses, the deliveied coal tonnage was probably not large enough to be representative of the entire deposit. Therefore, the coal in this deposit was assigned to the sulfur and the heating categories on the basis of the coal cores and not the delivered coal analyses.

9. Black Butte deposit. Approximately 88.5 million tons of remaining strippable DRB coal are present in coal beds of the Fort Union, Lance and Almond Formation in 

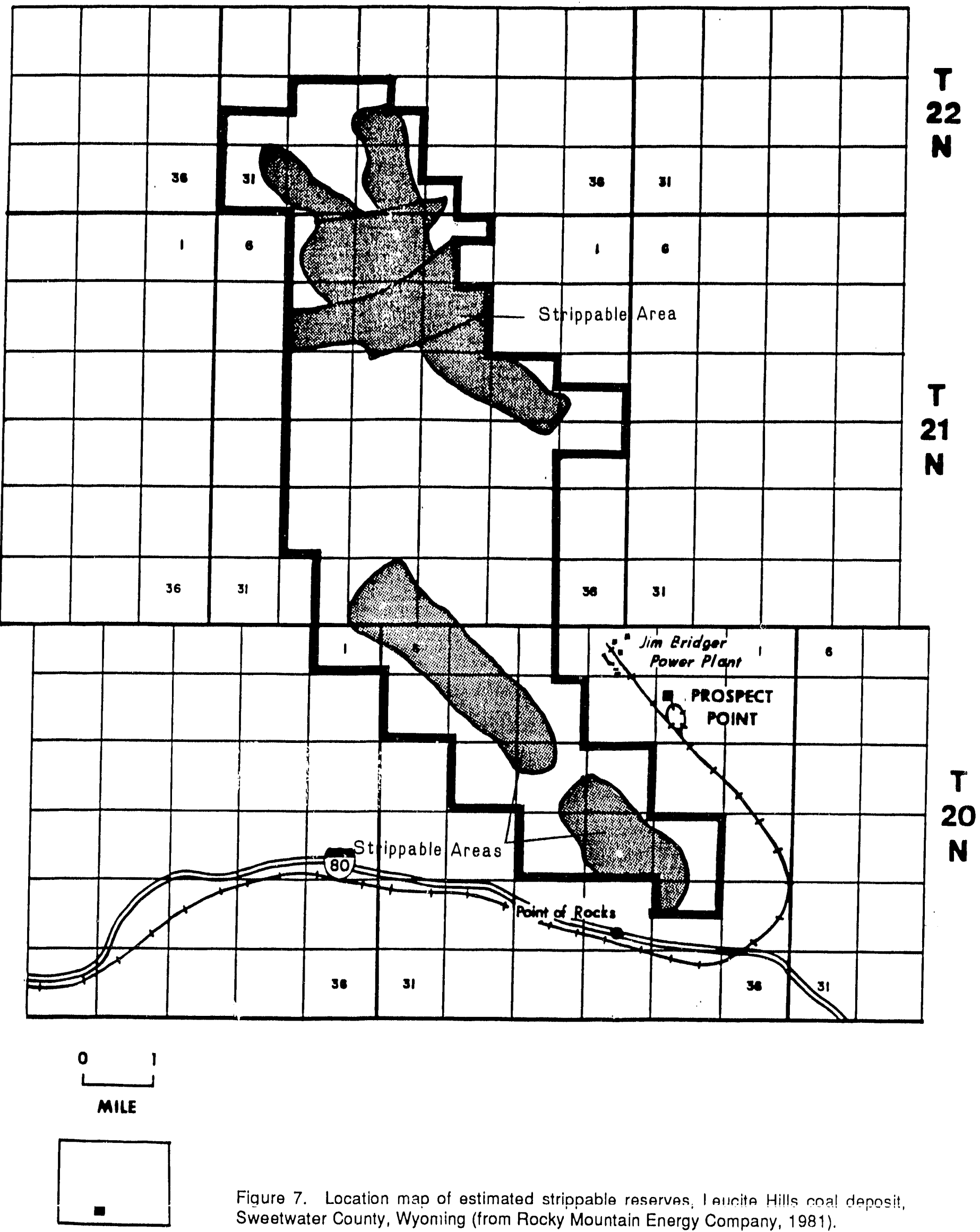

Fiqure 7. Location map of estimated strippable reserves, I alıite Hills noal denosit, Sweetwater County, Wyoming (from Rocky Mountain Energy Company, 1981). 
this deposit (Table 1 and Figure 8). The Almond and Lance Formations contain coals with the lower sulfur contents (from 0.41 to $0.60 \mathrm{lbs}$ sulfur/million Btu) and account for about 59 percent of the remaining strippable DRB in this deposit. Coals in the Fort Union Formation contain $0.61-0.83$ lbs sulfur/million Btu.

Strippable coal resources are estimated for coal beds over three feet thick and under less than 200 feet of overburden. Three to four minable coal beds in the Almond Formation of the Mesaverde Group have been named the D, C, A1, and A beds at Black Butte. The A1 and A coal beds merge to form the Lebar coal bed, which is correlative with the Mourning Dove bed mapped by the U.S. Geological Survey (Glass and Jones, 1991). As many as five minable coal beds occur in the Lance Formation at Black Butte: the Overland, Gibraltar, Black Butte, Maxwell, and Hall. These coals are each from 4 to 10 feet thick; the lower two coal beds have been correlated with the French and Bluff coal beds mapped by the U.S. Geological Survey (Glass and Jones, 1991). The lower part of the Fort Union Formation at Black Butte contains several minable coal beds, the Lower Little Valley and the Upper Little Valley. These beds reach a total combined thickness of about 25 feet and have been correlated with the Deadman coal(s) in the Jim Bridger deposit to the north. Additional strippable coal beds exist in the Black Butte area in the Fort Union and Wasatch Formations, but none of these are currently mined and none are included in the present resource estimates.

Original strippable DRB was reported as 82.6 million tons (Glass, 1981) but this estimate only includes coal resources that were dedicated to Black Butte Coal Company's contract with Idaho Power and Light. An additional 63.0 million tons should be added to this total to include coal resources dedicated to Black Butte Coal Company's contract with Commonwealth Edison (Black Butte Coal Company, 1976). The original strippable $\mathrm{DRB}$ for this deposit should be adjusted upward to 145.6 million tons. Original DRB for coal beds in each formation were tabulated from a "disturbance, mining and reclamation schedule" that appears on a mine map (Black Butte Coal Company, 1976). Cumulative coal production, by formation, plus mining and production losses (based on a 90 percent recovery factor) were used to calculate the remaining DRB as follows: 

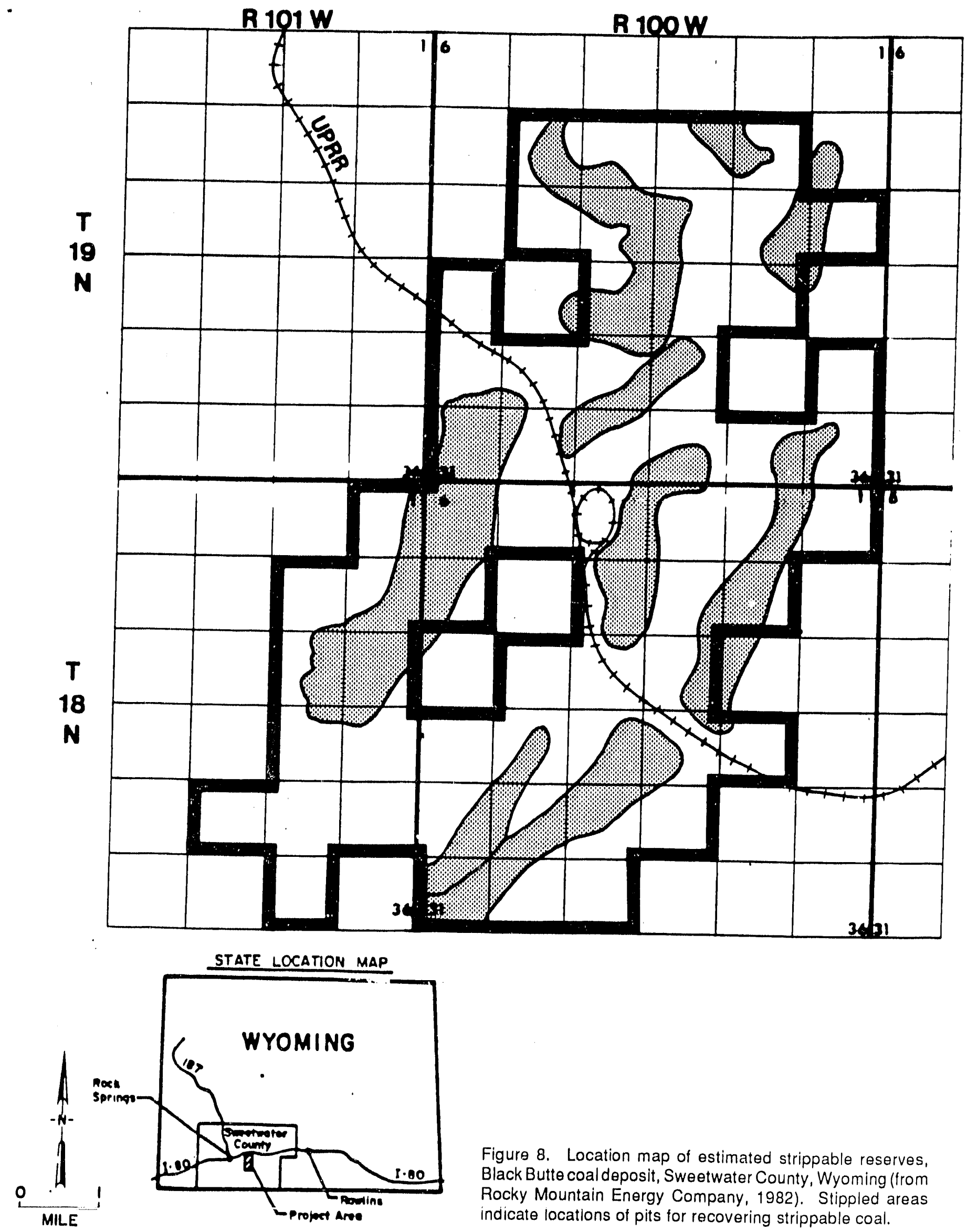

Figure 8. Location map of estimated strippable reserves, Black Butte coal deposit, Sweetwater County, Wyoming (from Rocky Mountain Energy Company, 1982). Stippled areas indicate locations of pits for recovering strippable coal. 
Calculations for remaining strippable DRB, in millions of tons.

Numbers in parentheses are negative.

\begin{tabular}{|c|c|c|c|c|c|}
\hline & & $\begin{array}{l}\text { Fort Union } \\
\text { Formation }\end{array}$ & $\begin{array}{c}\text { Lance } \\
\text { Formation } \\
\end{array}$ & $\begin{array}{l}\text { Almond } \\
\text { Formation }\end{array}$ & $\begin{array}{c}\text { Total } \\
\text { All Formatlons } \\
\end{array}$ \\
\hline A. & Original Strippable DRB & 79.2 & 48.8 & 17.6 & 145.6 \\
\hline B. & Coal Production & $(37.9)$ & $(11.5)$ & $(2.0)$ & $(51.4)$ \\
\hline C. & Mining Losses & $(4.2)$ & $(1.3)$ & $(0.2)$ & $(5.7)$ \\
\hline D. & $\begin{array}{l}\text { Production and Mining } \\
\text { Losses }(B+C)\end{array}$ & $(42.1)$ & $(12.8)$ & (2.2) & $(57.1)$ \\
\hline & $\begin{array}{l}\text { Remaining strippable } \\
D R B(A+D)\end{array}$ & 37.1 & 36.0 & 15.4 & 88.5 \\
\hline
\end{tabular}

Analytical data from 1,016 coal analyses (summarized in Table 7), including about 140 coal deliveries, were used to calculate weighted average sulfur contents and heating values by formation. The remaining strippable DRB for each formation was then assigned to the appropriate coal quality category. Weighted average heating values and sulfur contents from coal delivery data were not in agreement with average in-place coal quality: the average heating value of coal delivered from 1983 through 1990 is 19.09 million Btu/short ton, which is less than an average of 19.47 million Btu/short ton for all currently mined coal beds; the average sulfur content of coal deliveries was about 0.87 lbs sulfur/million Btu, which is more than the average of $0.68 \mathrm{lbs}$ sulfur/million Btu for all mined coal beds. Apparently, the coal delivery data is not indicative of the coal quality "in place" and was not used to characterize the strippable reserves in this deposit.

10. Salt Wells deposit. The 60 million tons of remaining strippable $D R B$ coal in this deposit occurs in the Almond Formation of the Mesaverde Group (Table 1). Because this deposit has not been mined, the original strippable DRB is also the remaining strippable DRB. The coals in this deposit are higher in heat content than most strippable coals in this coal field: their heating value is between 20.00 and 22.99 million Btu/short ton. The sulfur content of coals in this deposit is between 0.41 and $0.60 \mathrm{lbs}$ sulfur/million Btu, amongst the lowest for strippable coals in the Green River Coal Field. 
Strippable coal resources for the Almond Formation include coal beds over 2.5 feet thick (following the thickness limits for minable coal at Leucite Hills) and under less than 150 feet of overburden. Roehler (1974, 1979 a-c) has mapped and named $15 \mathrm{coal}$ beds in this deposit that are over 2.5 feet thick (Figure 9). In places, 12 of these coal beds are from 5 t. 10 feet thick; two coal beds are over 10 feet thick in places.

The Salt Wells strippable coal deposit consists of both privately-owned coal and Federal coal on the southeast flank of the Rock Springs uplift (Figure 10). Approximately 75 coal analyses were available for this deposit (Table 8). Although analyses for strippable coal beds in the Fort Union Formation were compiled for this report, no reserve base tonnages were available for these coal beds. An average of two weighted averages from exploration projects on both private and Federal coal lands was used to assign the Almond Formation coal resources to the appropriate sulfur and heating value categories. The average sulfur content for coal in the Almond Formation is $0.56 \mathrm{lbs}$ sulfur/million Btu and the average heating value is 20.76 million Btu/short ton. 


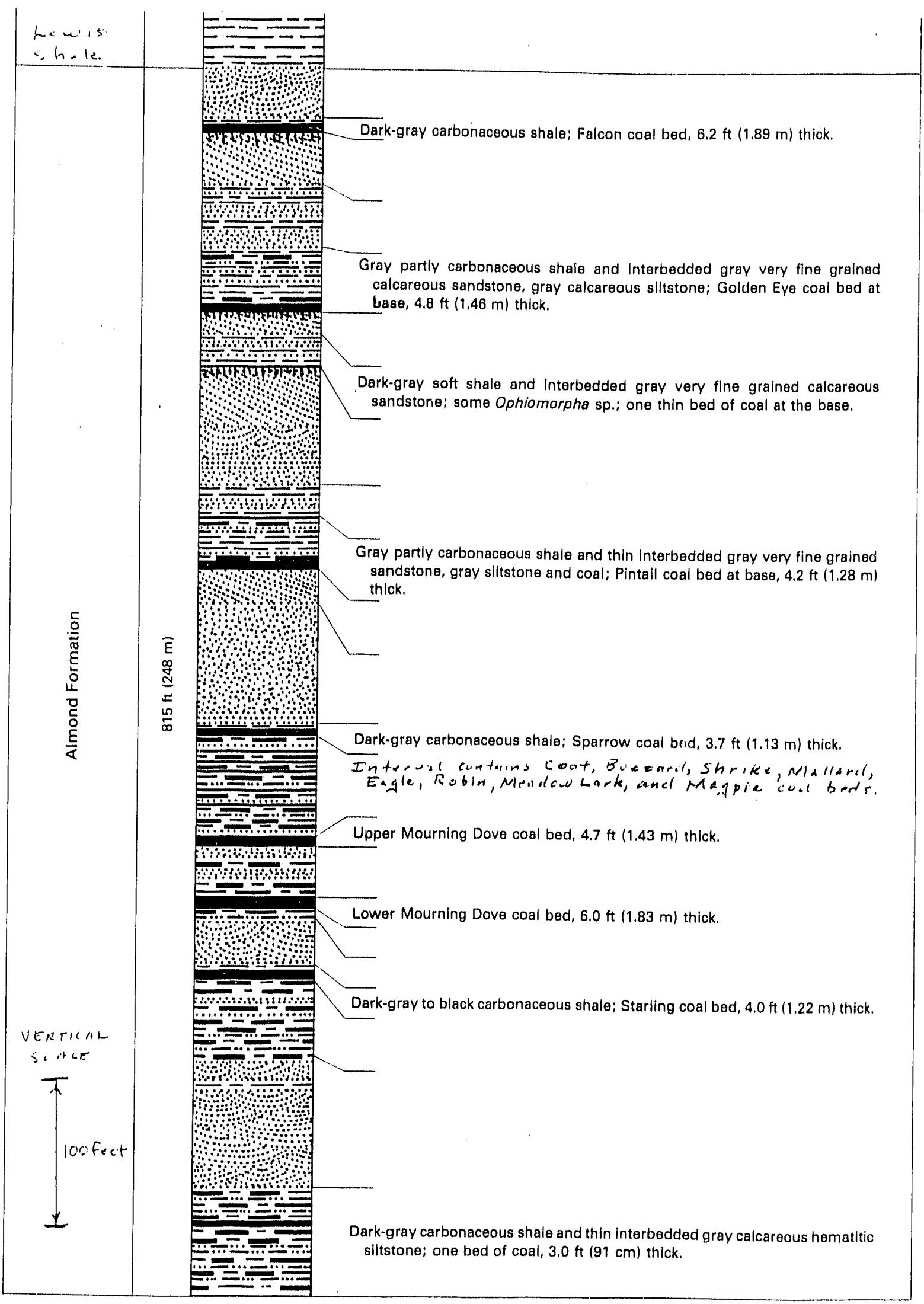

Figure 9. Approximate stratigraphic position and nomenclature for coal bede in the Almond Formation, Salt Wolls strippable deposit, Green River Coal Field (mocified from Roehler, 1979a-c). 

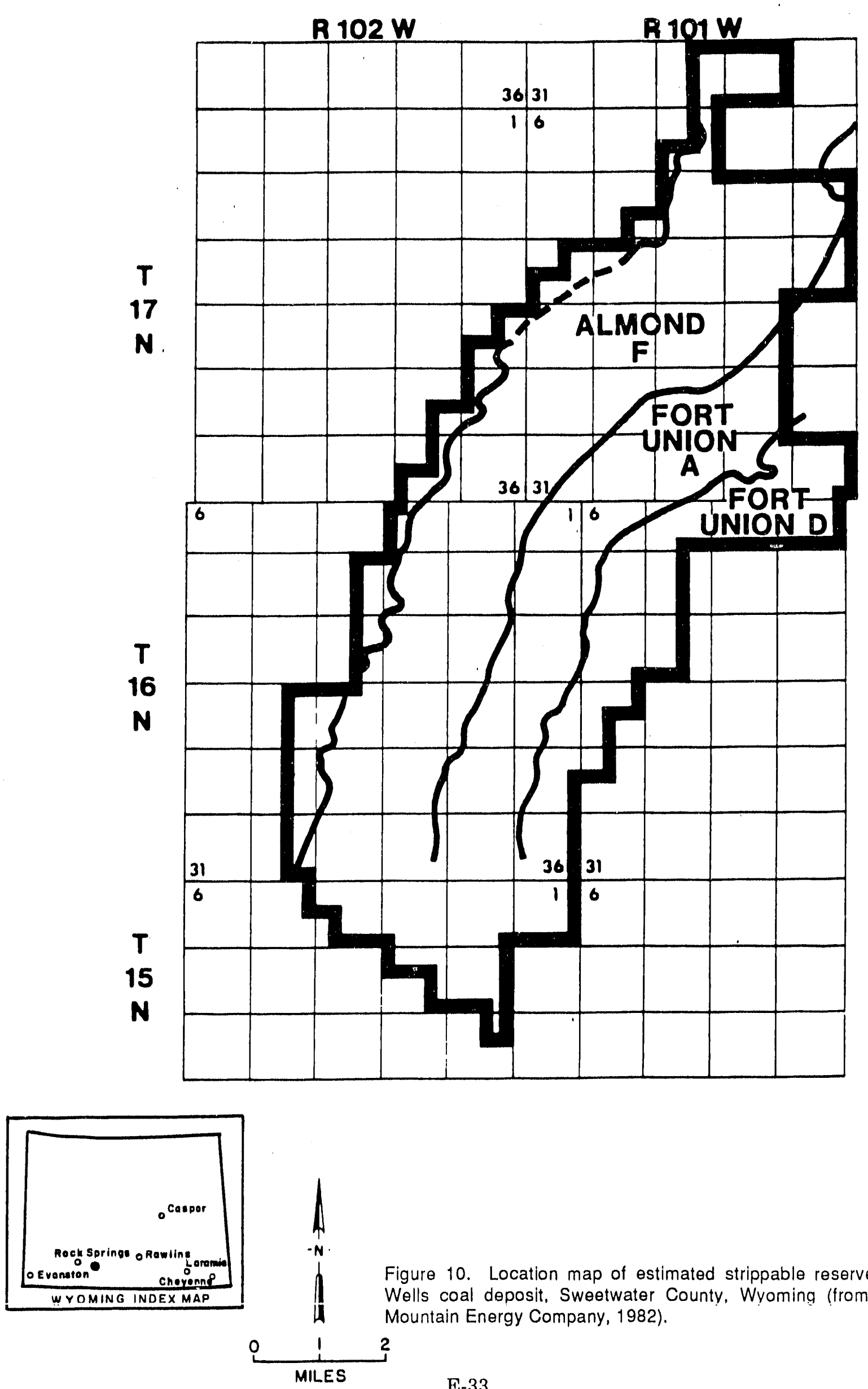

Figure 10. Location map of estimated strippable reserves, Salt Wells coal deposit, Sweetwater County, Wyoming (from Rocky Mountain Energy Company, 1982). 


\section{REFERENCES CITED}

Black Butte Coal Company, 1976, Surface mine permit application and mine plan, Volume 1: submitted to the State of Wyoming, Department Environmental Quality and the U.S. Geological Survey, Conservation Division.

Glass, G.B., 1981, Coal deposits of Wyoming: Wyoming Geological Association 32nd Annual Field Conference Guidebook, p. 181-236.

Glass, G.B., 1983, Coal deposits of Wyoming in Keystone Coal Industry Manual: McGraw-Hill, New York, p. 651-676.

Glass, G.B., and Jones, R.W., 1991, Coal fields and coal beds of Wyoming: Wyoming Geological Association 42nd Field Conference Guidebook, p. 133-167.

Honey, J.G., and Hettinger, R.D., 1989, Stratigraphic sections showing coal correlations within the lower coal zone of the Paleocene Fort Union Formation, Fillmore Ranch and Seaverson Reservoir Quadrangles, Carbon County, Wyoming: U.S. Geological Survey Coal Investigations Map C-127.

Masursky, Harold, 1962, Uranium-bearing coal in the eastern part of the Red Desert area, Wyoming: U.S. Geological Survey Bulletin 1099-B, p. B1-B52.

Northern Energy Resources Company, 1977a, [Coal] Exploration license application, Cherokee coal field: submitted to Wyoming Department of Environmental Quality, Figure 8, p. 21.

Northern Energy Resources Company, 1977b, Update and amendment of Mining Permit No. 338C: submitted to State of Wyoming, Department of Environmental Quality for Jim Bridger mine, Sweetwater County, Wyoming, Figure 17.

Pipiringos, G.N., 1961, Uranium-bearing coal in the central part of the Great Divide Basin; U.S. Geological Survey Bulletin 1099-A, 104 p.

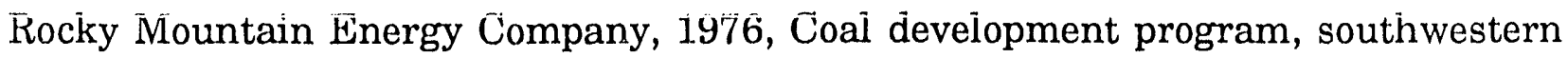
Wyoming: Rocky Mountain Energy Company informational publication, 39 p. 
Rocky Mountain Energy Company, 1981, Project activity update, March, 1981: Rocky Mountain Energy Company informational publication, $32 \mathrm{p}$.

Rocky Mountain Energy Company, 1982, Project activity update, July, 1982: Rocky Mountain Energy Company informational publication, $45 \mathrm{p}$.

Roehler, H.W., 1974, Geologic map of the Burley Draw Quadrangle, Sweetwater County, Wyoming: U.S. Geological Survey Geologic Quadrangle Map GQ-1200, scale 1:24,000.

Roehler, H.W., 1979a, Geologic map of the Camel Rock Quadrangle, Sweetwater County, Wyoming: U.S. Geological Survey Geologic Quadrangle Map GQ-1521, scale $1: 24,000$.

Roehler, H.W., 1979b, Geology of the Cooper Ridge NE Quadrangle, Sweetwater County, Wyoming: U.S. Geological Survey Professional Paper 1065-B, 45 p.

Roehler, H.W., 1979c, Geology and mineral resources of the Mud Springs Ranch Quadrangle, Sweetwater County, Wyoming: U.S. Geological Survey Professional Paper 1065-C, 35 p.

Smith, J.B., Ayler, M.F., Knox, C.C., and Pollard, B.C., 1972, Strippable coal reserves of Wyoming: U.S. Bureau of Mines Information Circular 8538, 51 p.

Wyoming Department of Environmental Quality and U.S. Office of Surface Mining Reclamation and Enforcement, 1983, [Draft] Red Rim, Wyoming, petition evaluation document/environmental impact statement: 35-11-425 WEQA 522 SMCRA Evaluation DEQ/OSM-PE-5, p. III-7 to III-9. 


\begin{abstract}
APPENDIX F. DEMONSTRATED RESERVE BASE OF S'IRIPPABLE COAL IN THE HANNA AND BIGHORN COAL FIELDS, WYOMNG.
\end{abstract}




\section{List of Tables}

Page

Table 1A. Summary of remaining demonstrated reserve base

(DRB) of strippable cual deposits in the Hanna Coal Field,

Wyoming, through December 31,1990 (in million short tons) ........................... F-5

Table 1B. Summary of remaining demonstrated reserve base

(DRB) of strippable coal deposits in the Bighorn Coal Field,

Wyoming, through December 31,1990 (in million short tons)

Table 2. Sulfur and heating values for the Corral Creek

Mining District, Hanna Coal Field, Wyoming.....

Table 3. Sulfur and heating values for the Carbon

Mining District, Hanna Coal Field, Wyoming

Table 4. Sulfur and heating values for the Hanna

Mining District, Hanna Coal Field, Wyoming

Table 5. Sulfur and heating values for the Seminoe

Mining District, Hanna Coal Field, Wyoming

F-15

Table 6. Sulfur and heating values for the Grass Creek

strippable coal deposit, Bighorn Coal Field, Hot Springs, County, Wyoming .......... F-18

Table 7. Coal delivery data for Hanna Coal Field mines (from FERC Form 423 data)......... F19

Table 8. Summary of remaining demonstrated reserve base

(DRB) of strippable coal deposits in the Corral Creek

Mining District, through December 31, 1990 (in million short tons)

Table 9. Summary of remaining demonstrated reserve base

(DRB) of strippable coal deposits in the Carbon Mining

District, through December 31, 1990 (in million short tons)

Table 10. Summary of remaining demonstrated reserve base

(DRB) of strippable coal deposits in the Hanna Mining

District, through December 31, 1990 (in million short tons)

Table 11. Summary of remaining demonstrated reserve

base (DRB) of strippable coal deposits in Seminoe Mining

District, through December 31, 1990 (in million short tons)

\section{List of Figures}

Figure 1. Coal mining districts in the Hanna Coal Field, Carbon

County, Wyoming (from Figure 2 of Glass and Roberts, 1979)

F-6 
Figure 2. Generalized stratigraphic columns for the Hanna Coal

Field of southcentral Wyoming (from Glass and Roberts, 1979)

Figure 3. Location map of estimated strippable coal reserves,

Corral Creek Mining District, Hanna Coal Field, Carbon County,

Wyoming (from Plate 4 of Glass and Roberts, 1979)

Figure 4. Coal nomenclature in the northern portion of the Corral Creek Mining

District of the Hanna Coal Field (modified from U.S. Geological

Survey Open-file Report 78-061) (from Glass and Roberts, 1979)

Figure 5. Coal nomenclature in the eastern portion of the Corral Creek Mining

District of the Hanna Coal Field (modified from U.S. Geological

Survey Open-file Report 78-060) (from Glass and Roberts, 1979)

Figure 6. Coal nomenclature in the central portion of the Corral Creek Mining

District of the Hanna Coal Field (modified from U.S. Geological

Survey Open-file Report 78-061) (from Glass and Roberts, 1979)

Figure 7. Coal nomenclature in the southern portion of the Corral Creek Mining

Distrivi of the Hanna Coal Field (modified from U.S. Geological

Survey Open-file Report 78-062). (from Glass and Roberts, 1979).

Figure 8. Location map of estimated strippable coal reserves,

Carbon Mining District, Hanna Coal Field, Carbon County,

Wyoming (froin Plate 1 of Glass and Roberts, 1979)

Figure 9. Coal nomenclature in the Carbon Mining District of

the Hanna Coal Field (from Glass and Roberts, 1979)

Figure 10. Location map of estimated strippable coal reserves,

Hanna Mining District, Hanna Coal Field, Carbon County,

Wyoming (from Plate 2 of Glass and Roberts, 1979)

Figure 11. Coal bed nomenclature in the Hanna and Seminoe

Mining Districts, Hanna Coal Field. (from Glass and Roberts, 1979)

Figure 12. Location map of estimated strippable coal reserves,

Seminoe Mining District, Hanna Coal Field, Carbon County,

Wyoming (from Plate 3 of Glass and Roberts, 1979)

Figure 13. Location map of the Grass Creek strippable coal deposit,Bighorn Coal

Field, Hot Springs County, Wyoming (from U.S. Geological Survey, 1974) F-36 
1. Summary. The remaining demonstrated reserve base (DRB) of strippable coal in the Hanna and Bighorn Coal Fields is 566.02 and 17.99 million short tons, respectively (Tables 1A and 1B). Coal deposits in the four mining districts of the Hanna Coal Field (Figure 1) occur in the Late Cretaceous Almond Formation (of the Mesaverde Group) and Medicine Bow Formation, the Late Cretaceous and early Tertiary (Paleocene) Ferris Formation, and the early Tertiary (Paleocene and Eocene) Hanna Formation (Figure 2). Strippable coal in the Bighorn Coal Field occurs in the Fort Union For mation (Paleocene). In the Hanna Coal Field, about 353 million tons (62 percent) of the total occurs in the Hanna Formation and about 196 million tons (35 percent) of the total occurs in the Ferris Formation.

Approximately 72 percent ( 410 million tons) of the 566.02 million tons of strippable DRB in the Hanna Coal Field is in the 20.00-22.99 million Btu/short ton heating content category; the remaining 28 percent ( 155.78 million tons) of the total has a heating content of 15.00-19.99 million Btu/short ton. The Hanna Formation contains most of the higher heating value coals; only a small amount of coal in the Hanna Formation is less than 20.00 million Btu/short ton. Strippable coals in the Bighorn Coal Field contain heating values from 20.00 to 22.99 million Btu/short ton.

The Hanna Coal Field contains strippable coal in each of the six sulfur content categories. About 71 percent of the reserves in this coal field contain less than $0.84 \mathrm{lbs}$ sulfur/million Btu and nearly half the coal in the field contains $0.41-0.60 \mathrm{lbs}$ sulfur/ million Btu. The highest sulfur coals in the coal field occur in the Hanna Formation of the Carbon Mining District. Most of the lowest sulfur coals in the coal field occur in the Ferris Formation of the Seminoe Mining District. All of the strippable coal in the Bighorn Coal Field contains 0.41-0.60 lbs sulfur/million Btu.

Significant amounts of coal have been produced from all mining districts except the Corral Creek Mining District in the Hanna Coal Field. Since the last estimate of 648.29 million tons of remaining strippable DRB (Glass, 1979), about 45.4 million tons of coal have been depleted (through production and mining losses) from reserves in the Hanna Mining District and about 36.87 million tons of coal have been depleted from reserves in the Seminoe Mining District. The remaining strippable DRB for the Hanna Coal Field is now estimated at 566.02 million short tons. 
Table 1A. Summary of remaining demonstrated resenve base (DRB) of strippable coal deposits in the Hanna Coal Fieid, Wyoming, through Docomber 31, 1990 (in million short tons).

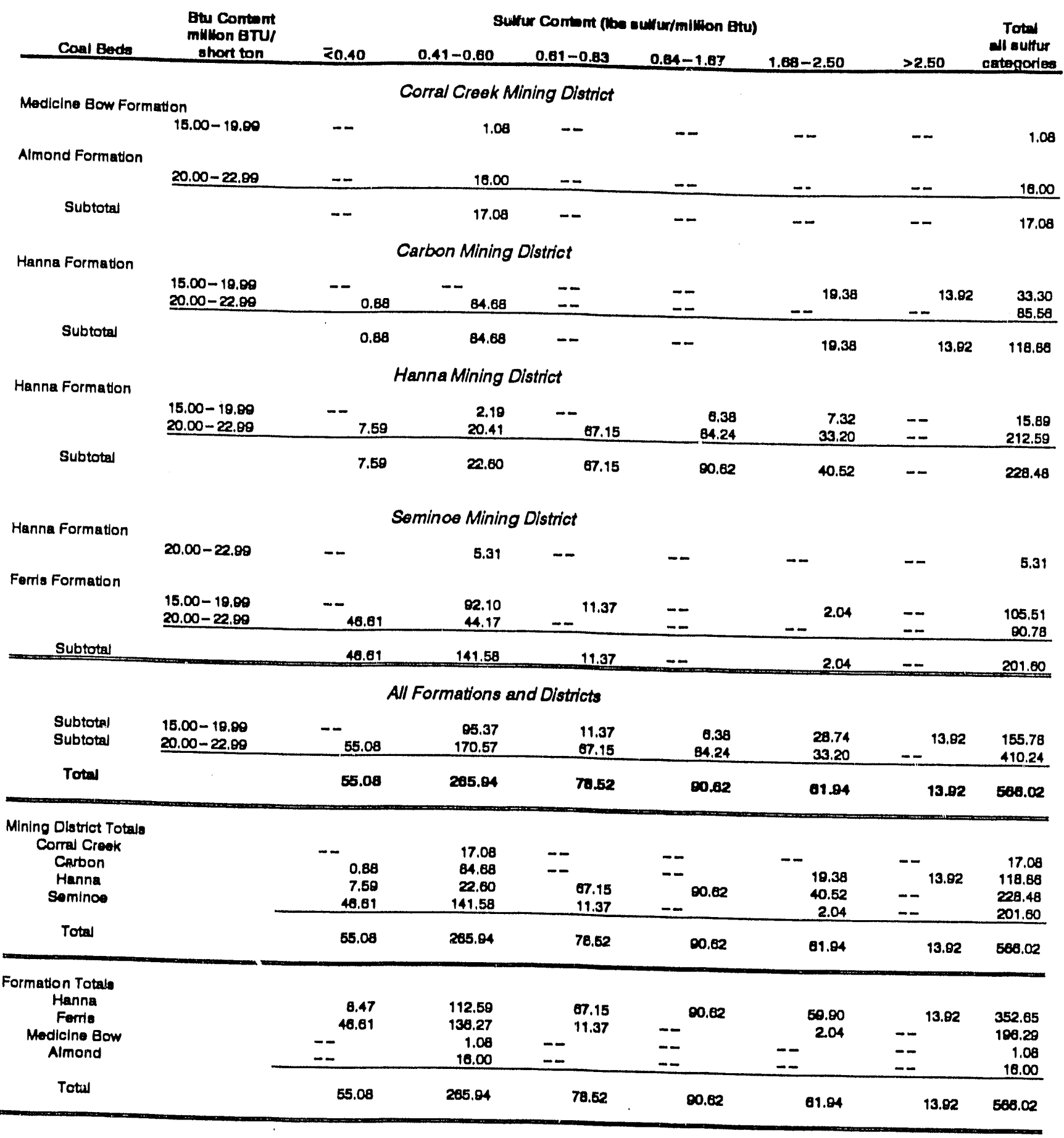

Table 1B. Summary of remaining demonstrated reserve base (DRB) of strippable coal deposits in the Bighom Coal Feld, Wyoming, through Decomber 31, 1990 (in million short tons).

\begin{tabular}{|c|c|c|c|c|c|c|c|c|}
\hline \multirow[b]{2}{*}{ Coal Bede } & \multirow{2}{*}{$\begin{array}{l}\text { Btw Contont } \\
\text { millon BTU/ } \\
\text { shout ton }\end{array}$} & \multicolumn{4}{|c|}{ Suffur Content (Ibe sulurr/million Btu) } & \multirow[b]{2}{*}{$1.60-2.50$} & & \multirow{2}{*}{$\begin{array}{c}\text { Total } \\
\text { Nll sulfur } \\
\text { Categorlea }\end{array}$} \\
\hline & & $\leq 0.40$ & $0.41-0.60$ & $0.61-0.83$ & $0.84-1.67$ & & $>2.50$ & \\
\hline rom Union rm. & $20.00-22.00$ & -- & 17.8 & -- & -- & -- & - & \\
\hline
\end{tabular}




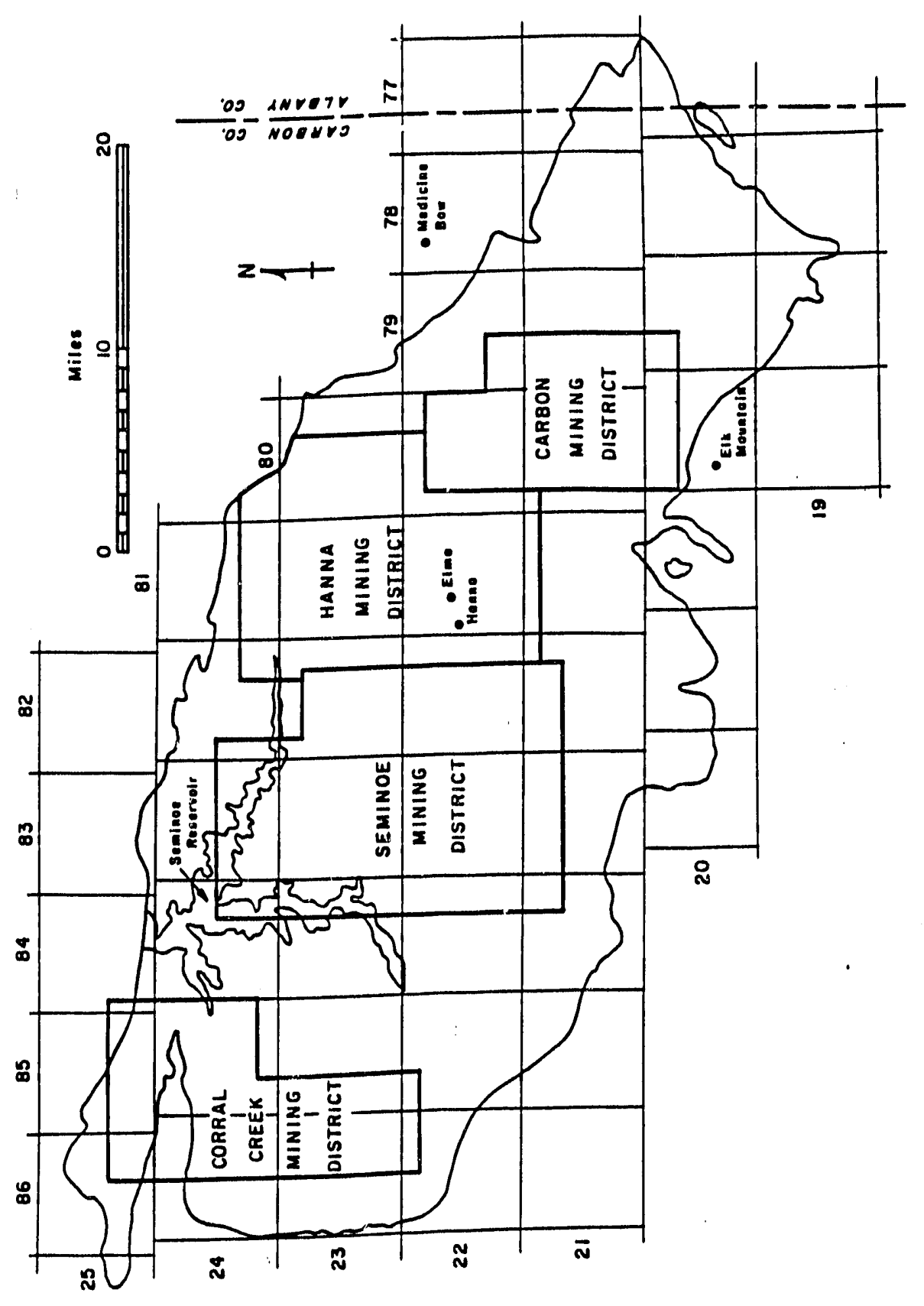

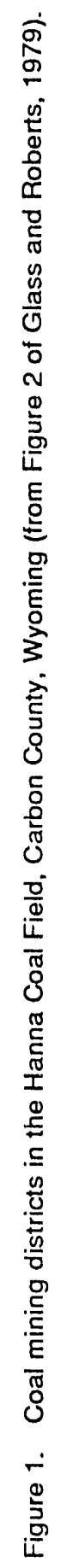




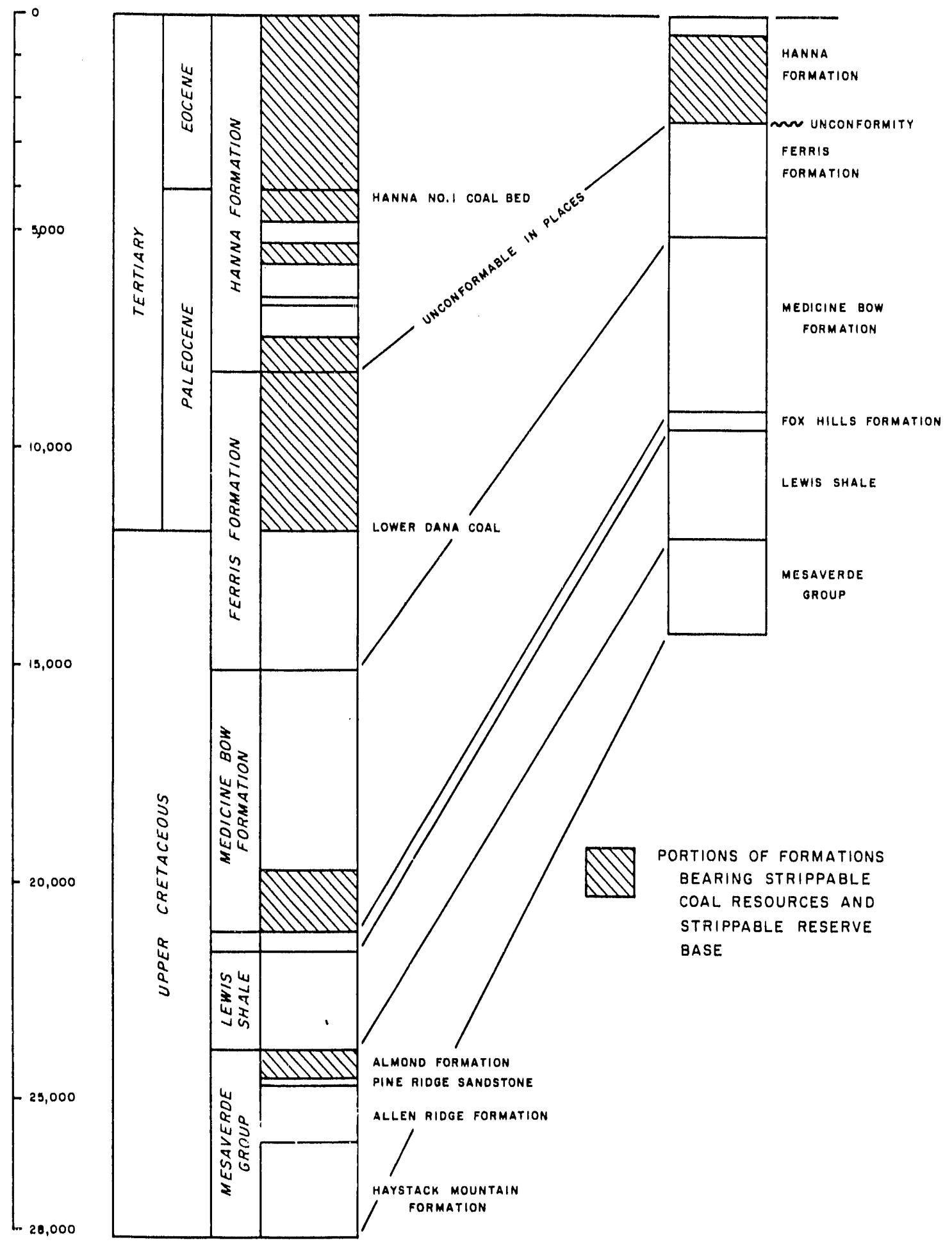

Vertical scole

In Feel

Figure 2. Generalized stratigraphic columns for the Hanna Coal Field of southcentral Wyoming (from Glass and Roberts, 1979). 
Production and mining losses of 0.61 million tons from the Grass Creek strippable coal deposit in the Bighorn Coal Field have reduced the 18.60 million tons of reserves originally estimated for this field to 17.99 million short tons.

2. Methodology and assumptions. The last estimate of strippable $D R B$ for the Hanna Coal Field (Glass and Roberts, 1979) was made on a bed-by-bed basis for each mining district in the coal field. Strippable coal in this field includes coal beds 5 feet thick or more (plus thinner beds that are currently being surface mined) that lie between 0 and 200 feet of cover. The 1979 estimate incorporated mining and production losses to January 1, 1978. Additional mining and production losses from that date through December 31,1990 , are included in the present estimate.

For the present report, all available coal analyses were compiled by coal bed. Average or weighted average sulfur and heating values were determined for each coal bed, and where appropriate, average analyses used by Glass and Roberts (1979) were revised. Production and mining losses for each coal bed were calculated using a recovery factor of 80 percent. An 80 -percent recovery factor means that 80 percent of the total inplace coal reserves was recovered, and that 20 percent of the in-place conl reserves was not recovered because of mining losses and other inefficiencies. A recovery factor 88 percent was used for the strippable coal deposit in the Bighorn Coal Field. The remaining demonstrated reserve base for each coal bed was then assigned to the appropriate sulfur and heating value category. Coal beds with no analytical data were assigned sulfur and heating values based on the average sulfur content and heating value for all coal beds in the same formation within a coal mining district.

Coal bed nomenclature follows that of Glass and Roberts (1979). Industry-derived coal production, coal delivery, and analytical data were adjusted to conform to that report. Some industry-derived production data contained coal bed names not included in earlier reports; these bed names were incorporated into the terminology used by Glass and Roberts (1979) and the production and mining losses subtracted from the reserves estimated by Glass and Roberts (1979). No additional strippable coal reserves were added to those of Glass and Roberts (1979).

3. Analyses. Coal analyses used in this report were taken from various published and unpublished sources (Tables 2-6). Whenever possible, analyses located within a strippable coal deposit were used to assign coal quality categories to the DRB. In some 
cases, however, analyses of nearby coal beds, analyses from adjacent underground mines, or analyses from deep drill holes were used to characterize a specific coal bed or a coal deposit. Analyses from 237 core, channel, and tipple samples and about 604 coal deliveries were used to characterize the strippable DRB in the Hanna Coal Field. Analyses from 60 core, channel, and tipple samples were used to characterize the strippable DRB in the Bighorn Coal Field.

Coal delivery data reported by mine (Table 7) could not be used to characterize a specific coal bed because the data represents aggregate production from more than one coal bed. The coal delivery data was used, instead, to verify coal quality at the mine. Sulfur and heating values from coal deliveries reported from each mine were weighted by the tonnage of each delivery; a weighted average for all deliveries for all years was then determined. In-place coal quality at the mine was determined by averaging the analyses of individual coal beds within the mine.

All analyses were evaluated on an individual basis where appropriate. Analyses from poorly located data points were not used. Analyses with anomalously low heating values due to weathering or high ash contents were also not used. Where only partial thicknesses of a coal bed were sampled and analyzed and no other information was available nearby, the data was not considered representative of the entire coal bed and were not used in this study. Where only partial thicknesses of a coal bed were sampled and analyzed and there was other information on coal thicknesses and quality (of complete coal beds) available nearby, the analyses were weighted by linear footage sampled.

4. Corral Creek Mining District. Strippable coal beds in the Medicine Bow and Almond Formations (Figure 3) account for 17.08 million tons of the DRB for the Hanna Coal Field. Analyses are available from three channel samples of Medicine Bow Formation coals and from core samples of Almond Formation coals at an exploration/ development project (Table 2). The Medicine Bow Formation contains three strippable coal beds (Figures 4 and 5; Table 8) and the Almond Formation contains seven strippable coal beds (Figures 6 and 7; Table 8). Coal beds with an estimate of strippable DRB tonnage, but with no coal analyses, were assigned to coal quality categories based on an average heating value and sulfur content for all coal beds in either the Almond or the Medicine Bow Formations in this mining district. 


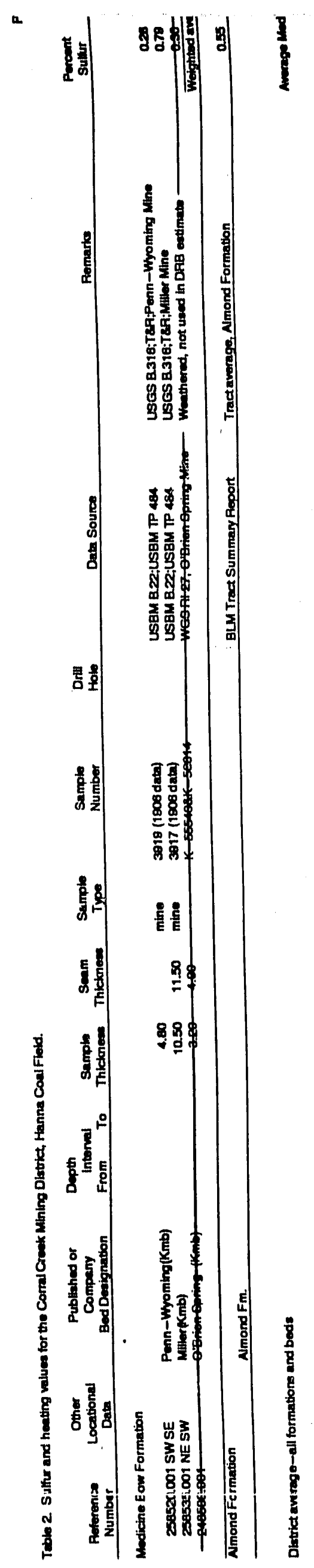

F-10 


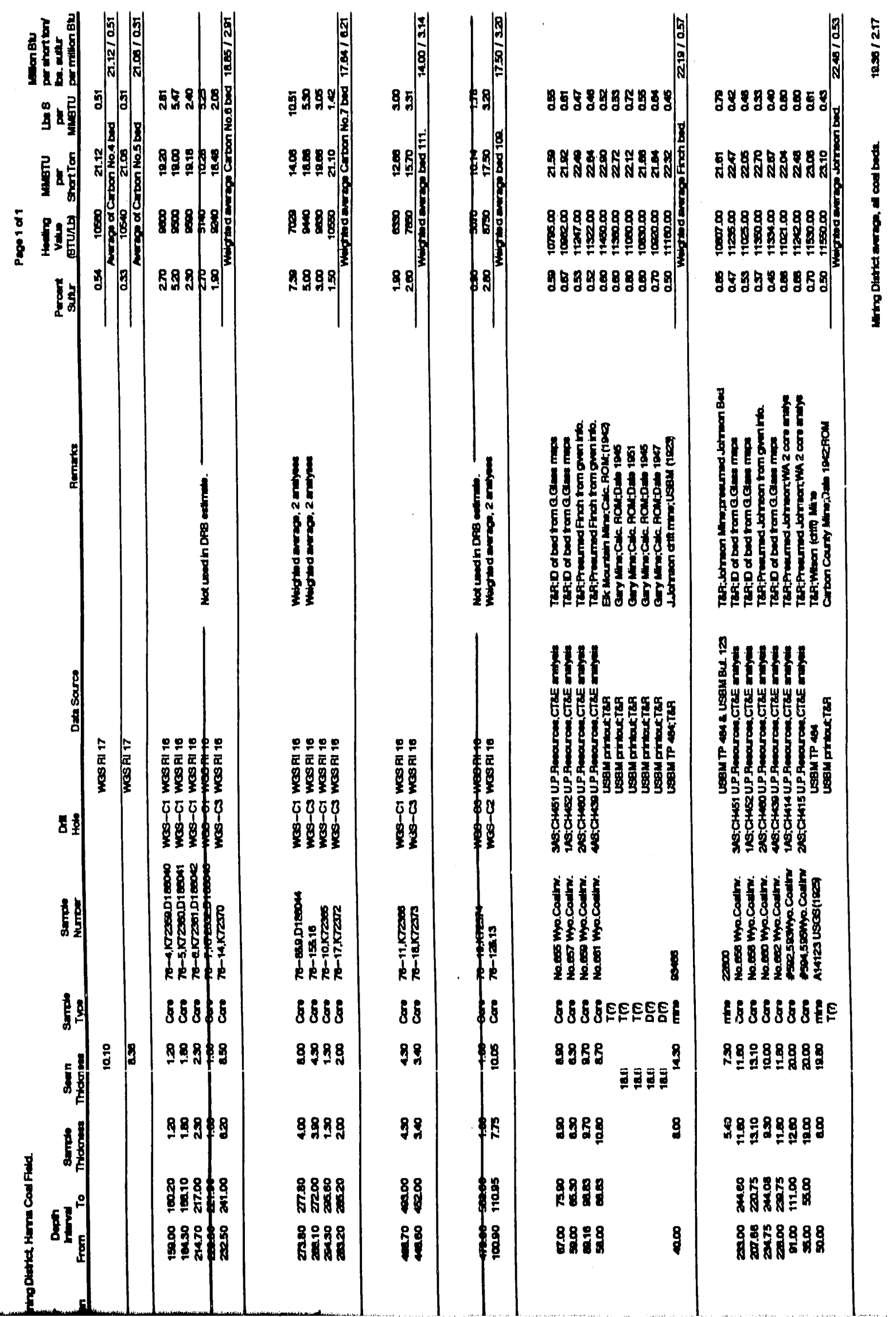




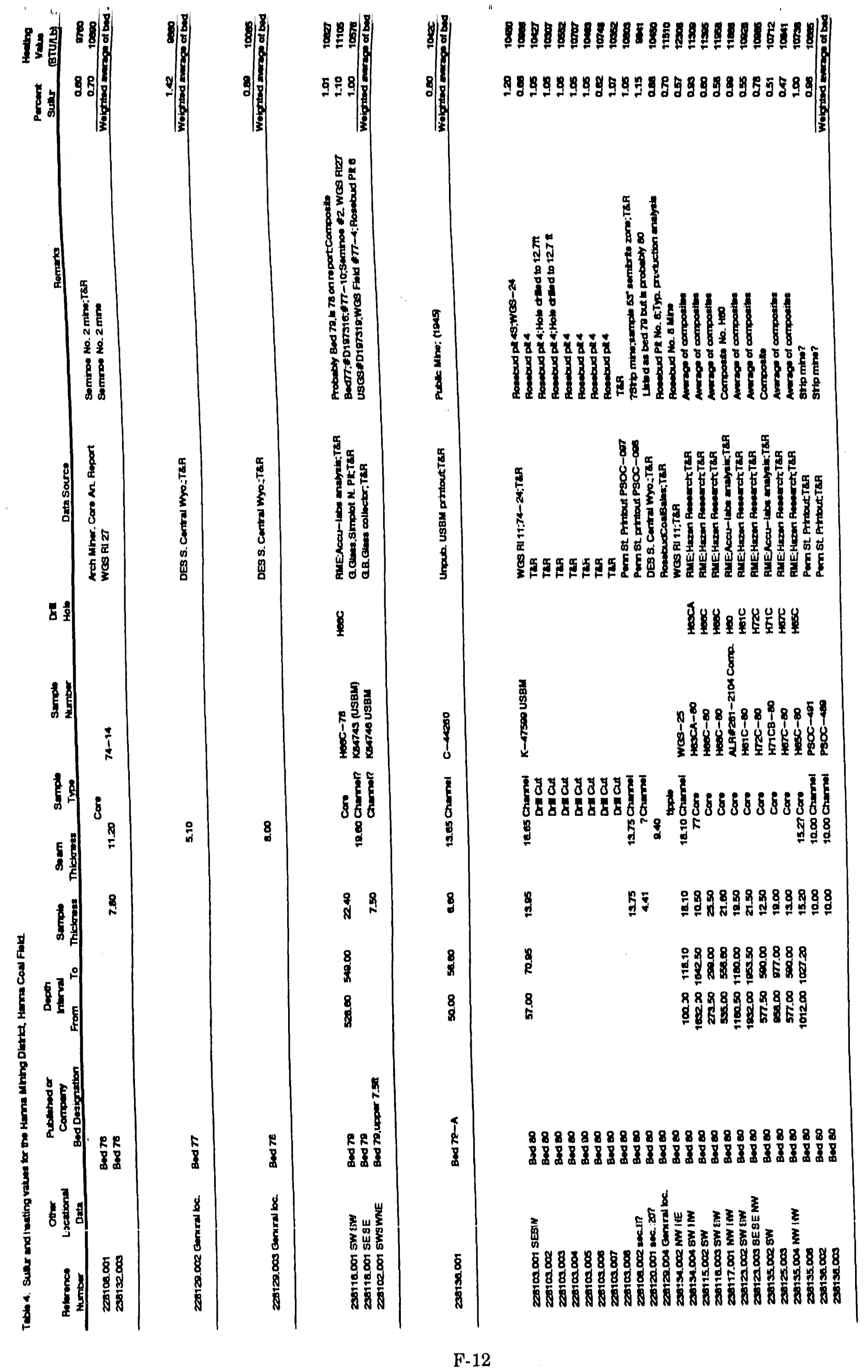




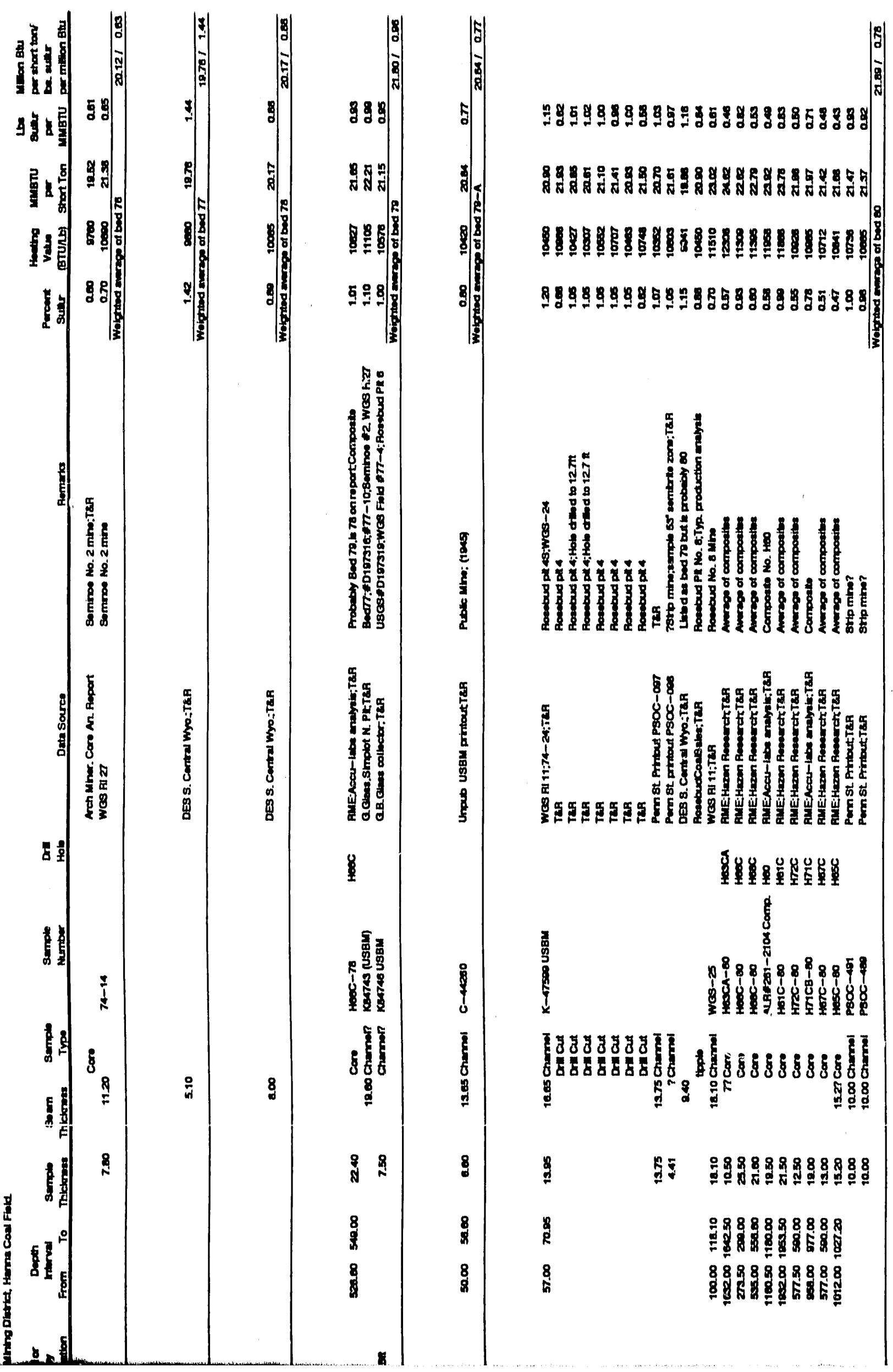




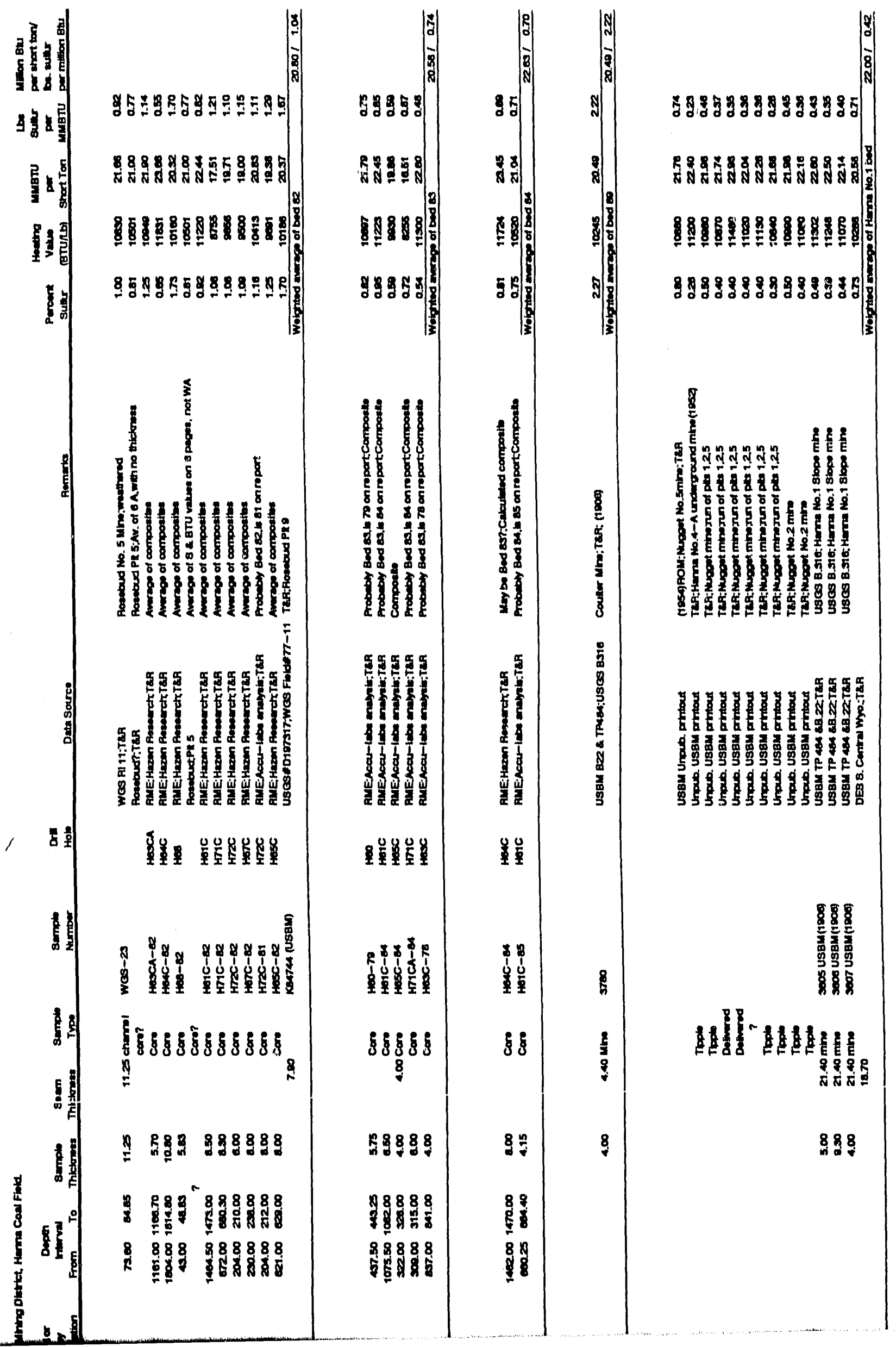




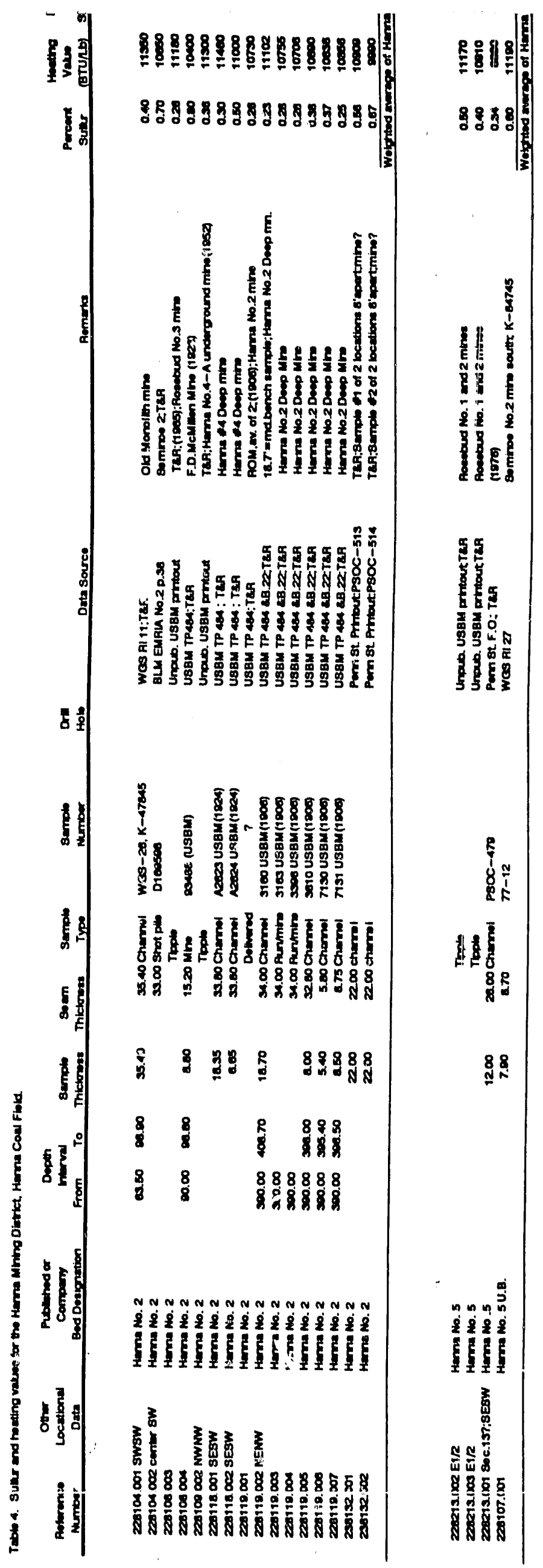

F-14 


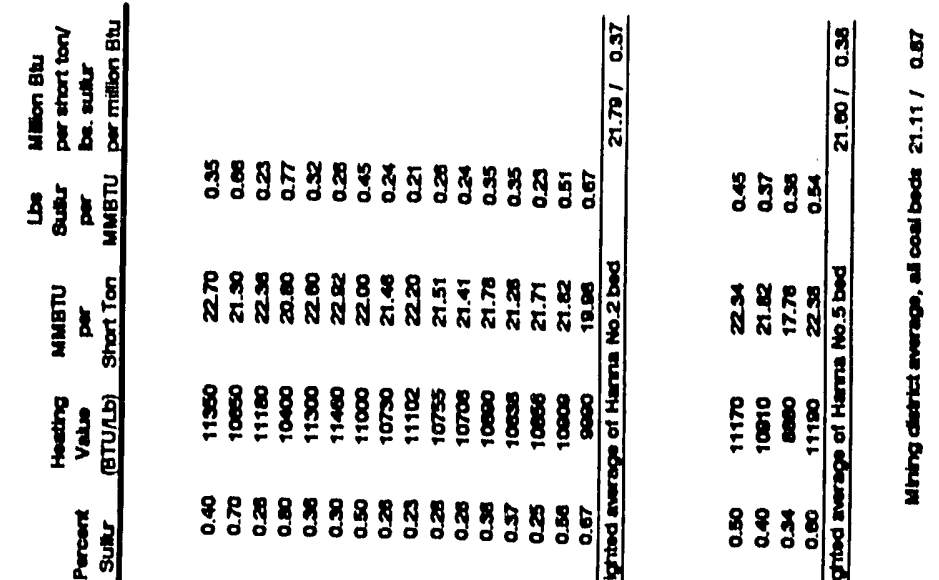




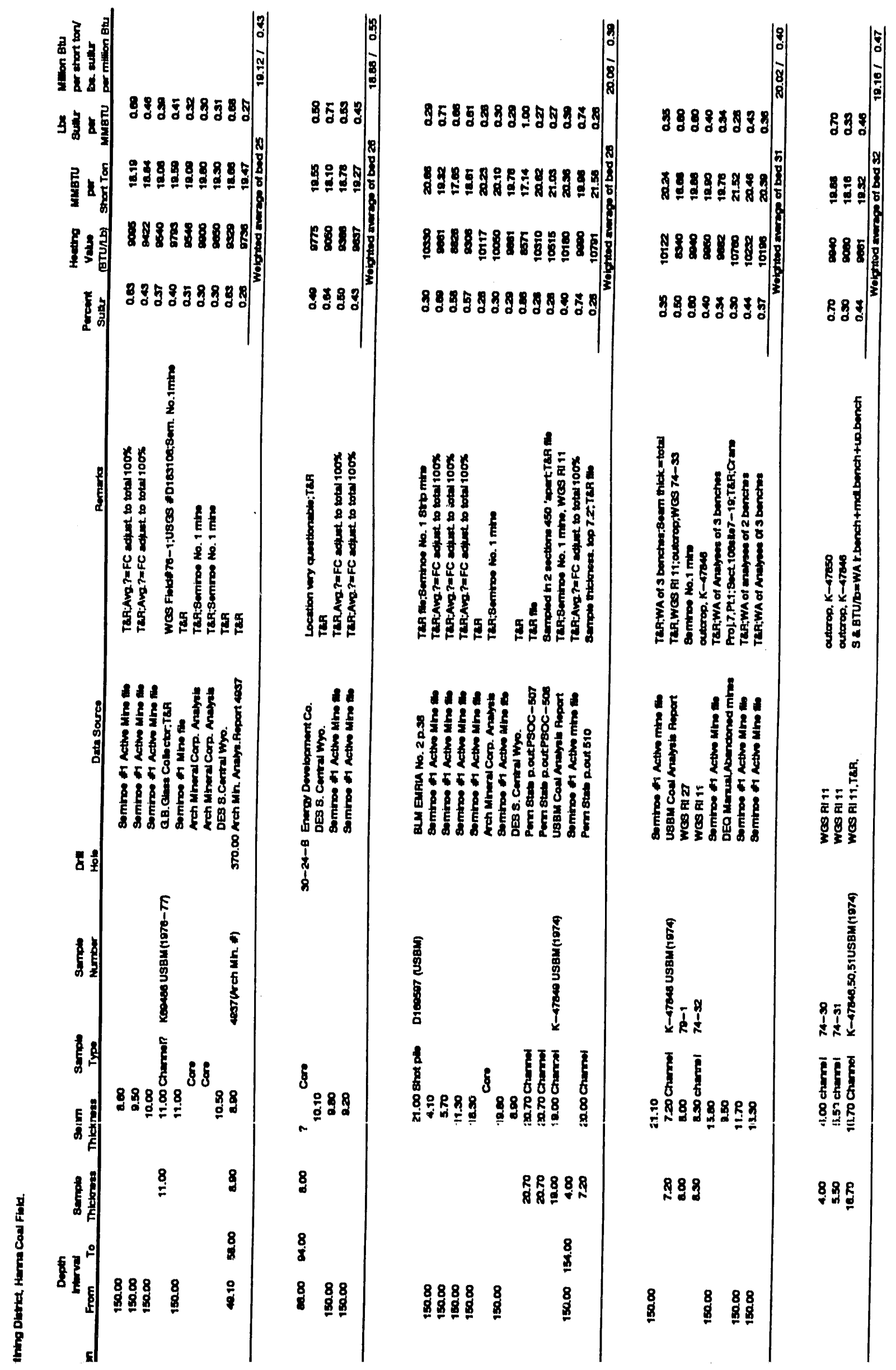




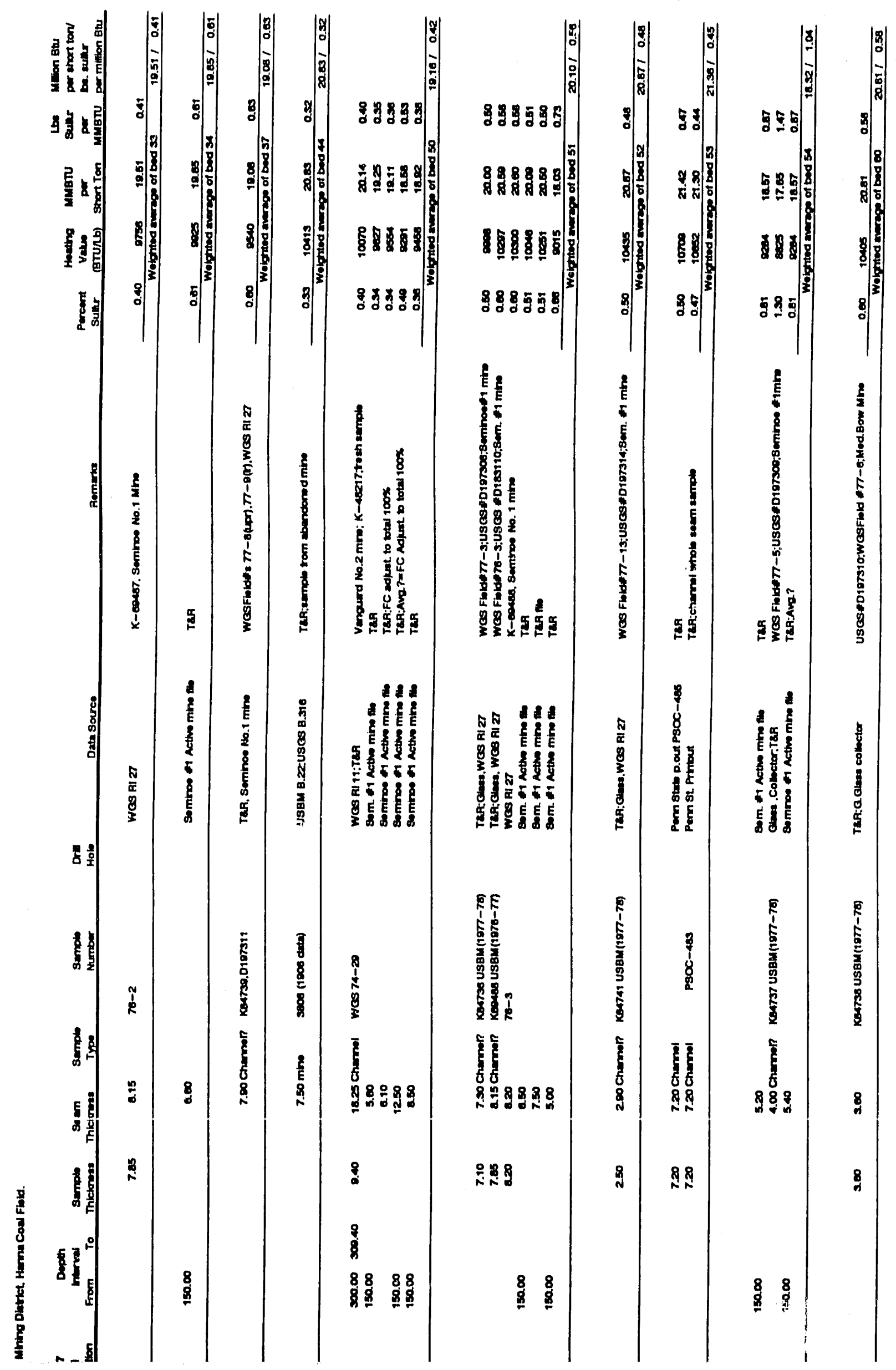




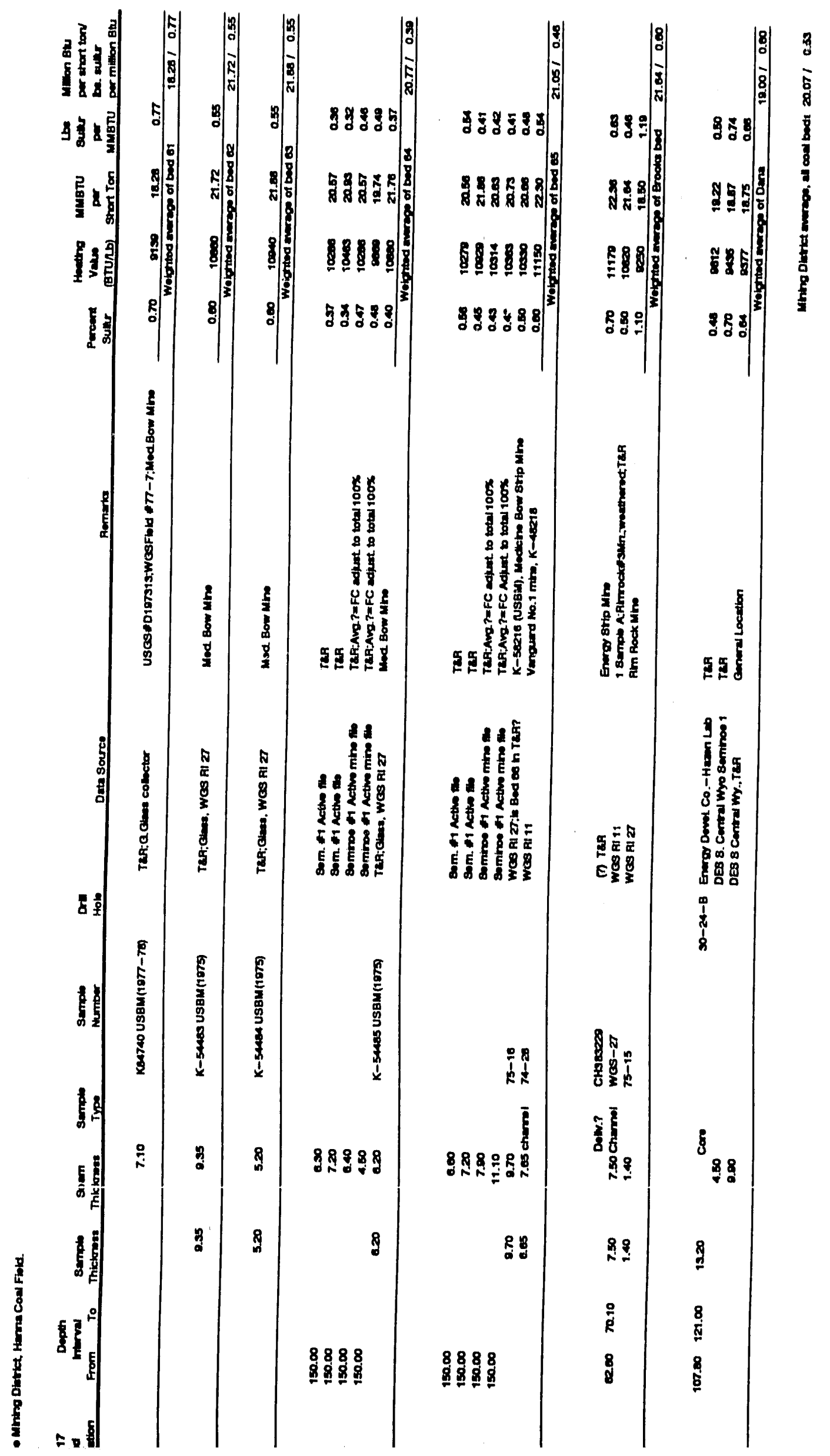




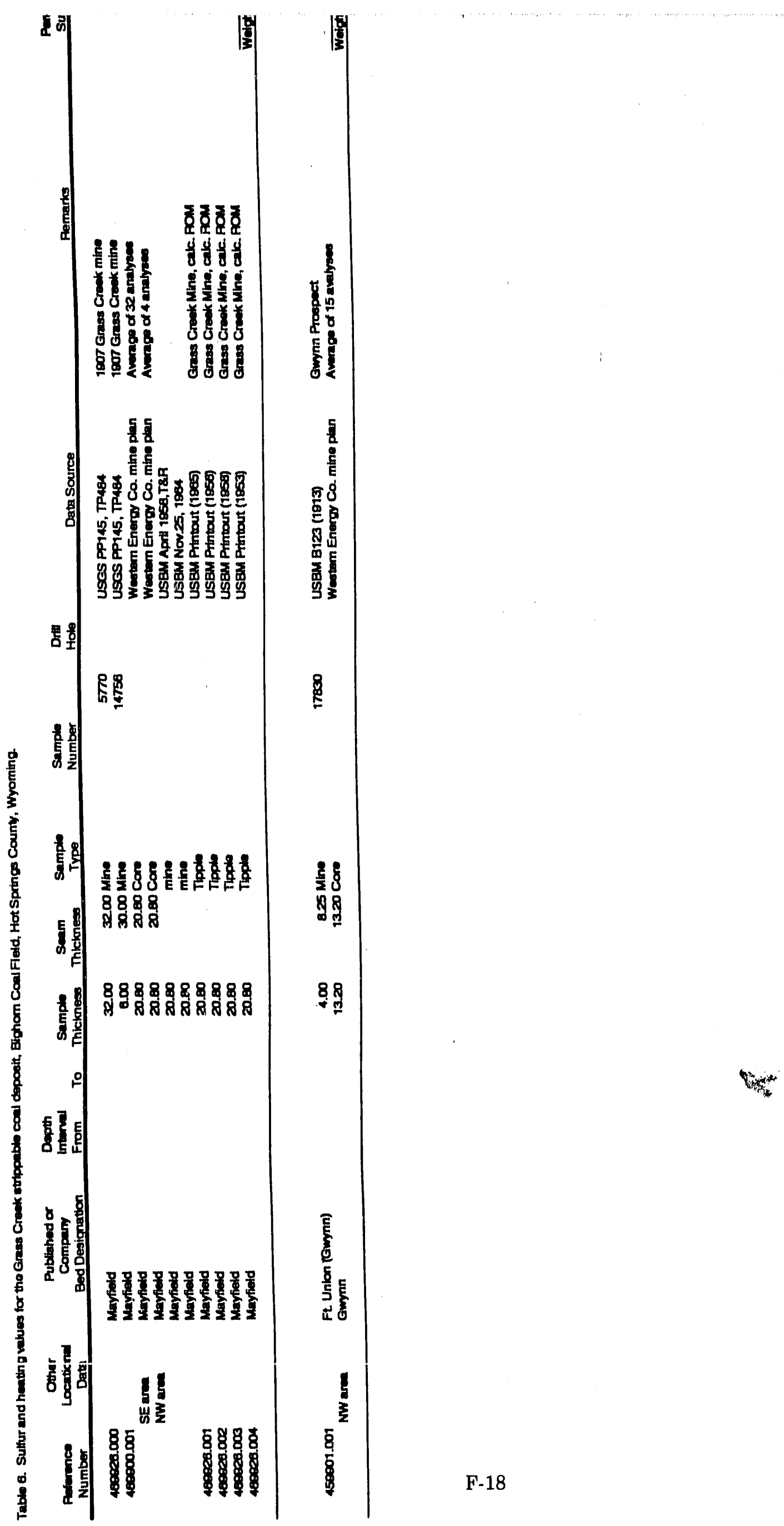




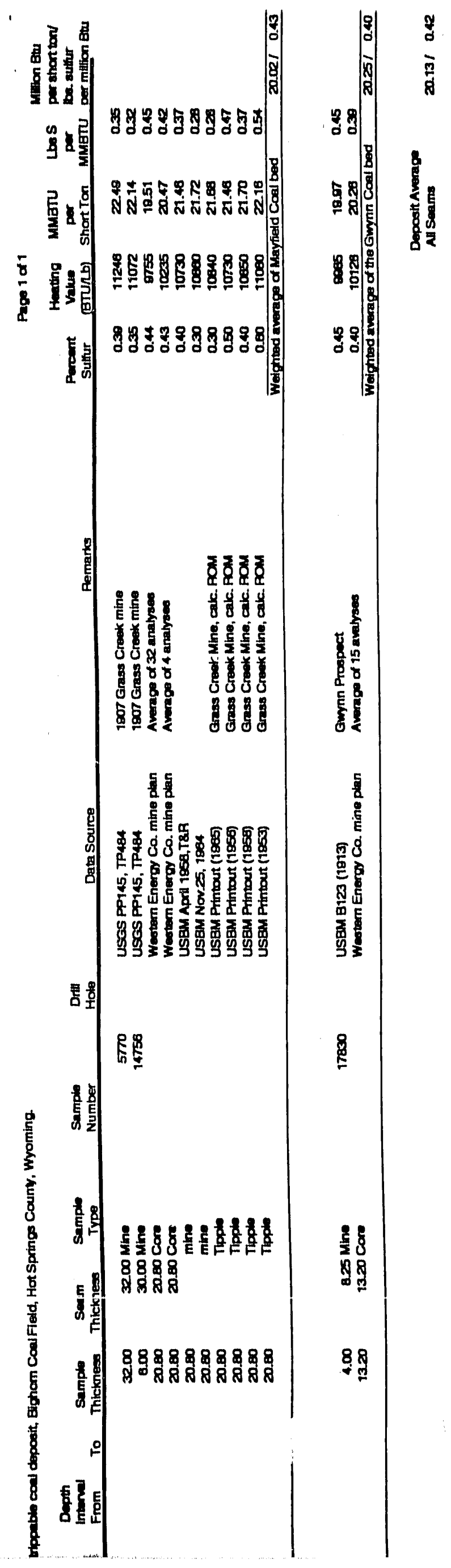




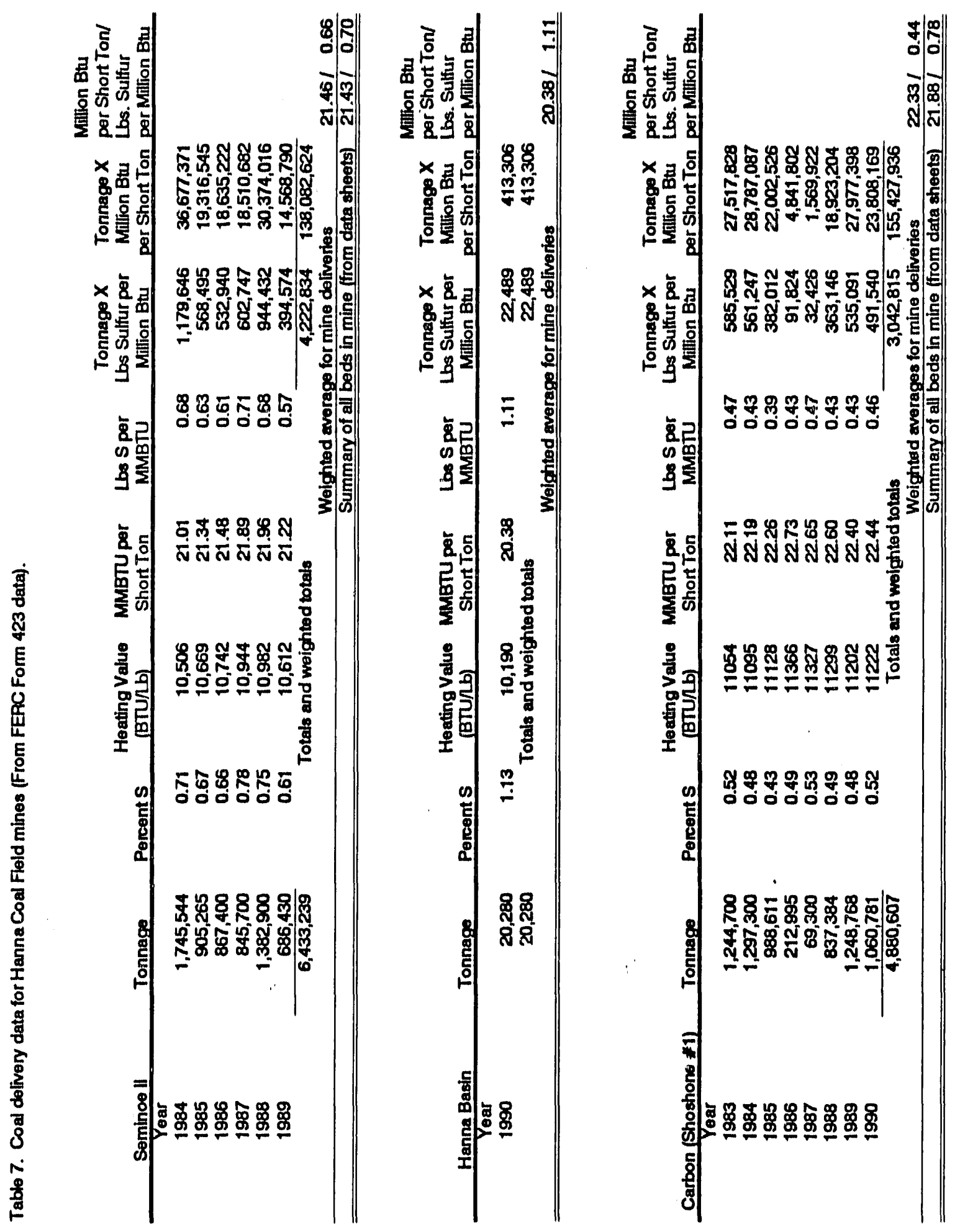




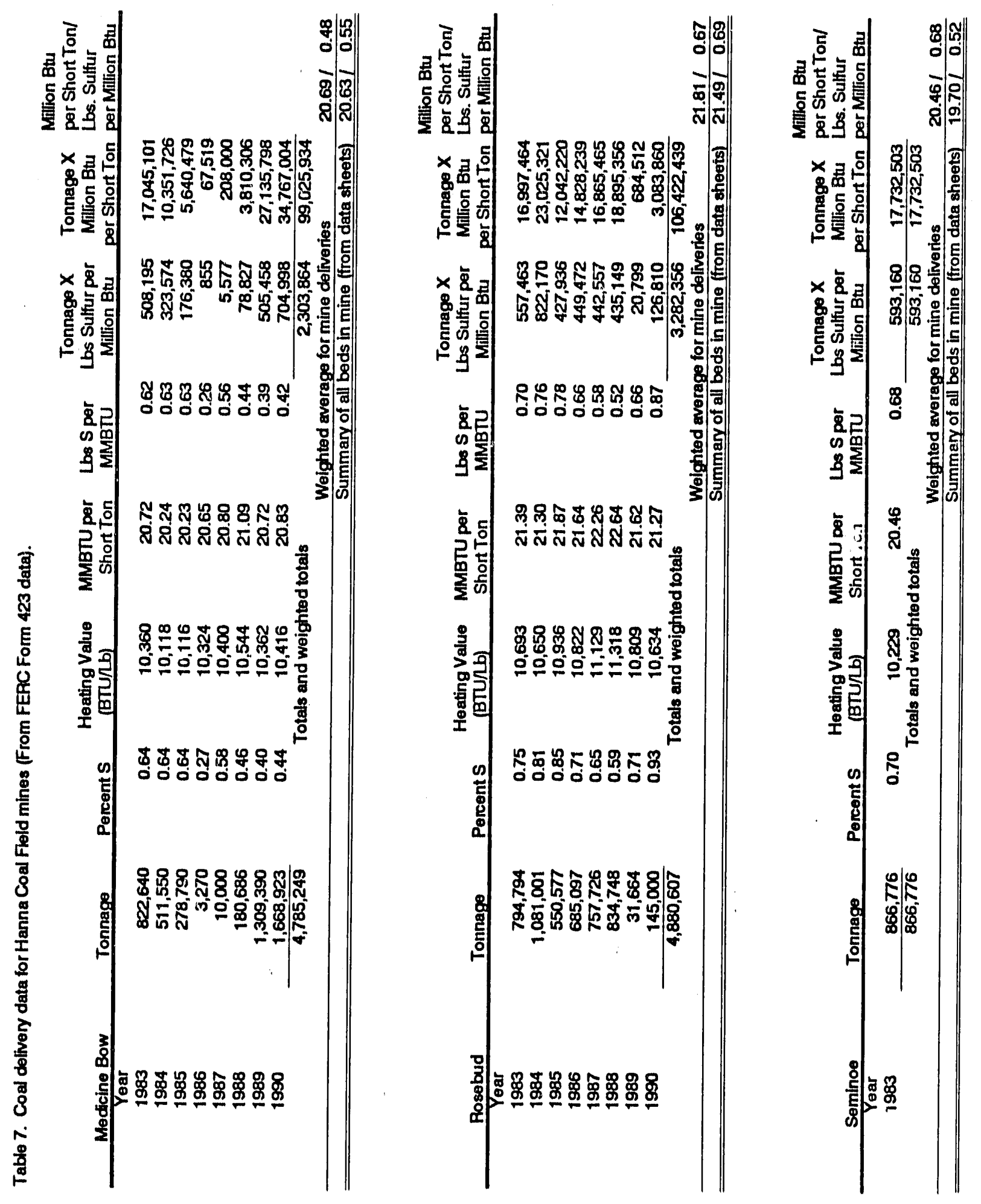





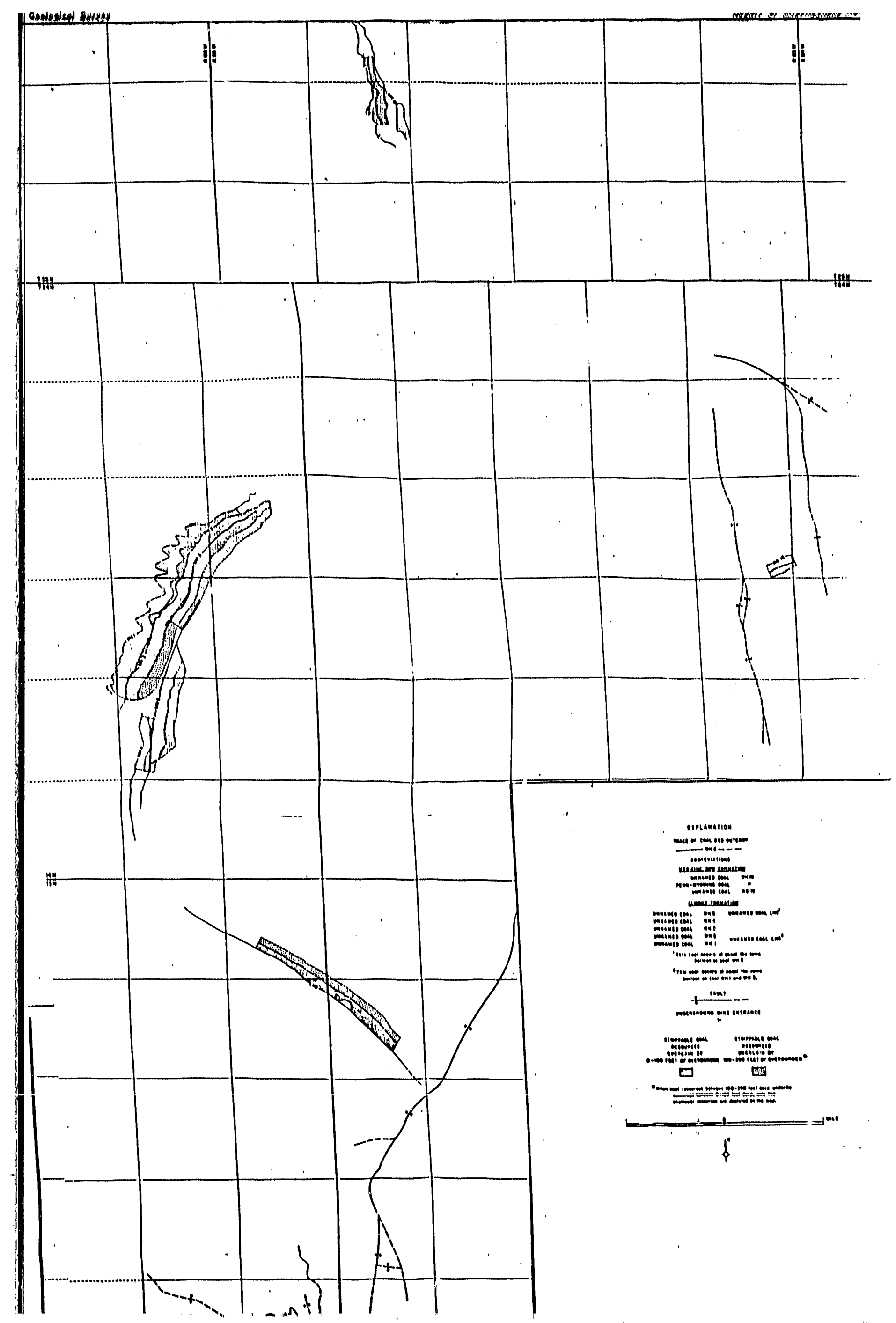




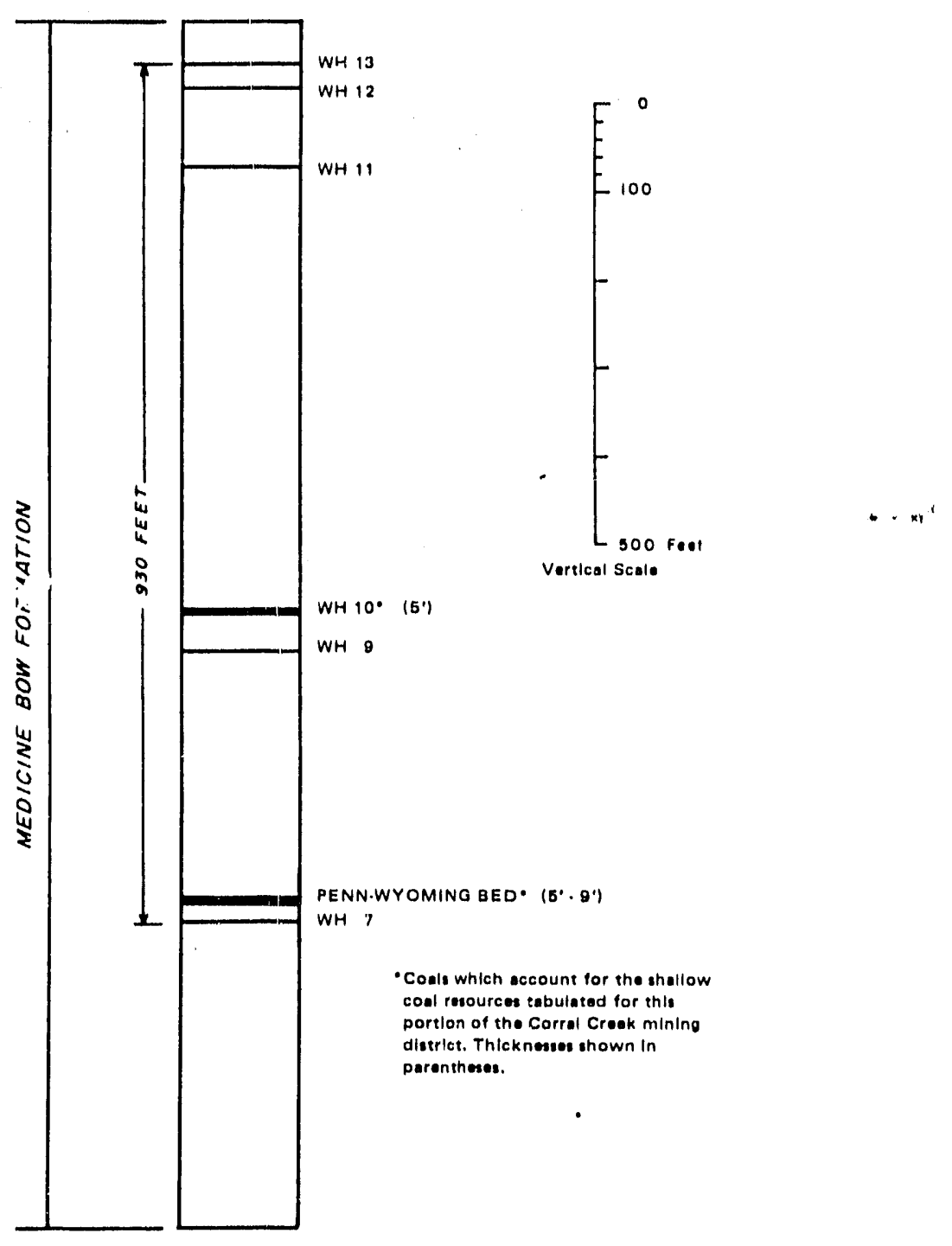

Figure 4. Coal nomenclature in the northern portion of the Corral Creek Mining District of the Hanna Coal Field (modified from U.S. Geological Survey Open-file Report 78-061) (from Glass and Roberts, 1979). 


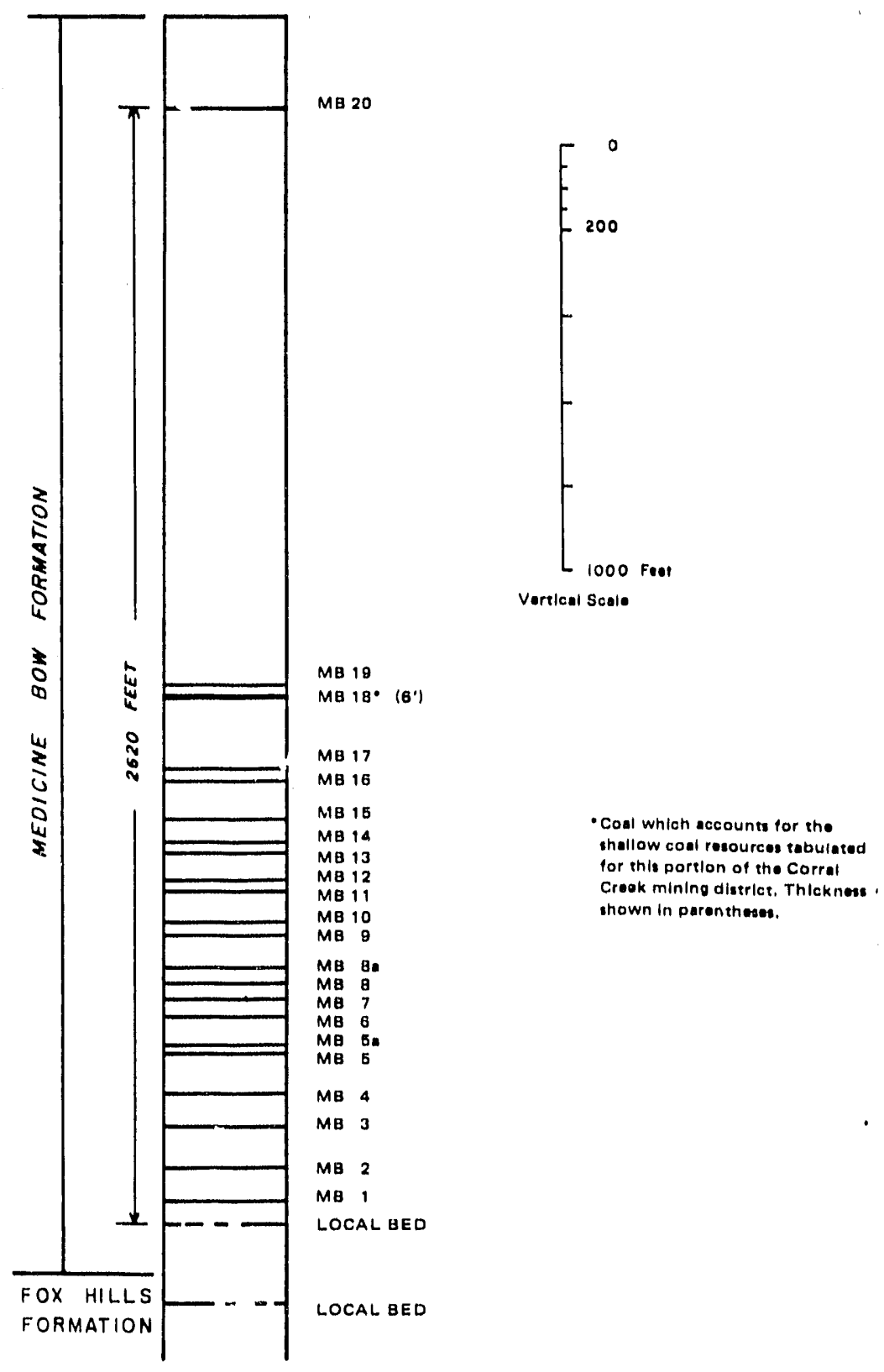

Figure 5. Coal nomenclature in the eastern portion of the Corral Creek Mining District of the Hanna Coal Field (modified from U.S. Geological Survey Open-file Report 78-060) (from Glass and Roberts, 1979). 


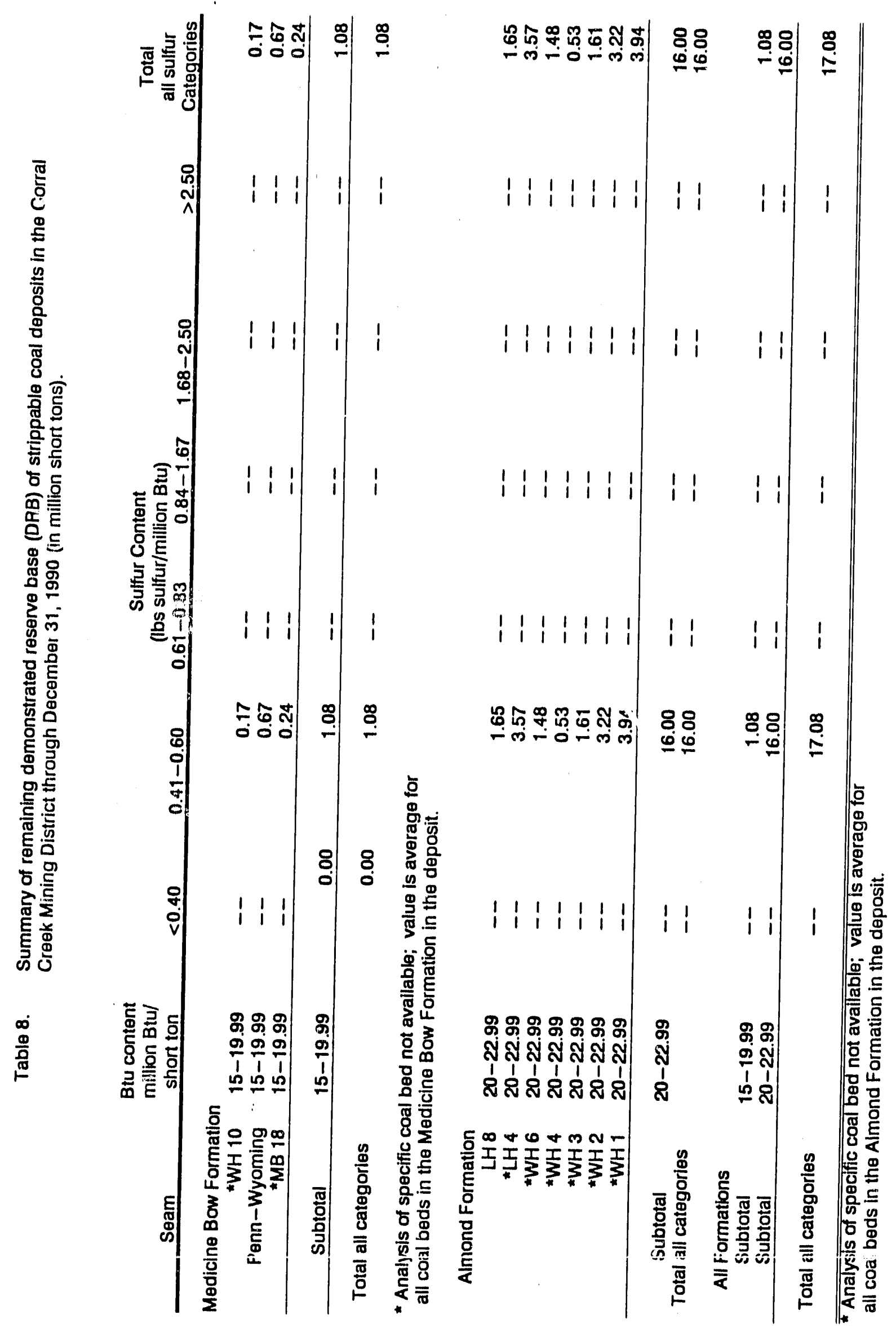




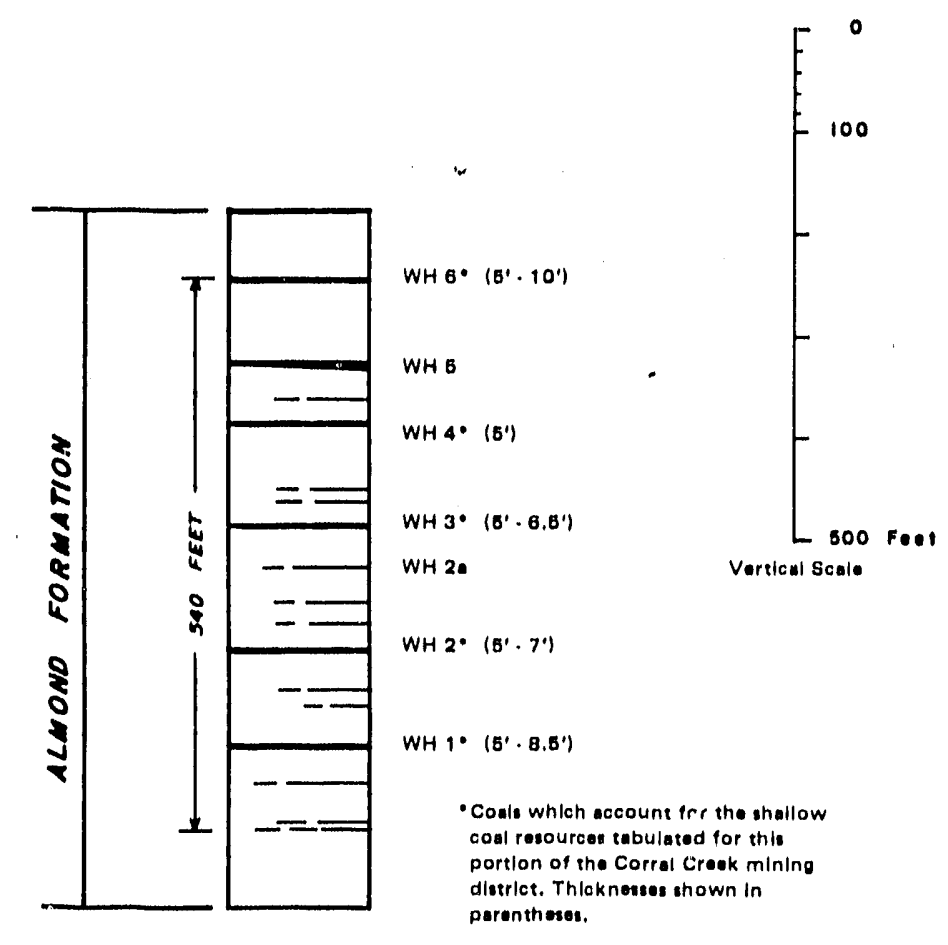

Figure 6. Coal nomenclature in the central portion of the Corral Creek Mining District of the Hanna Coal Field (modified from U.S. Geological Survey Open-file Report 78-061) (from Glass and Roberts, 1979).

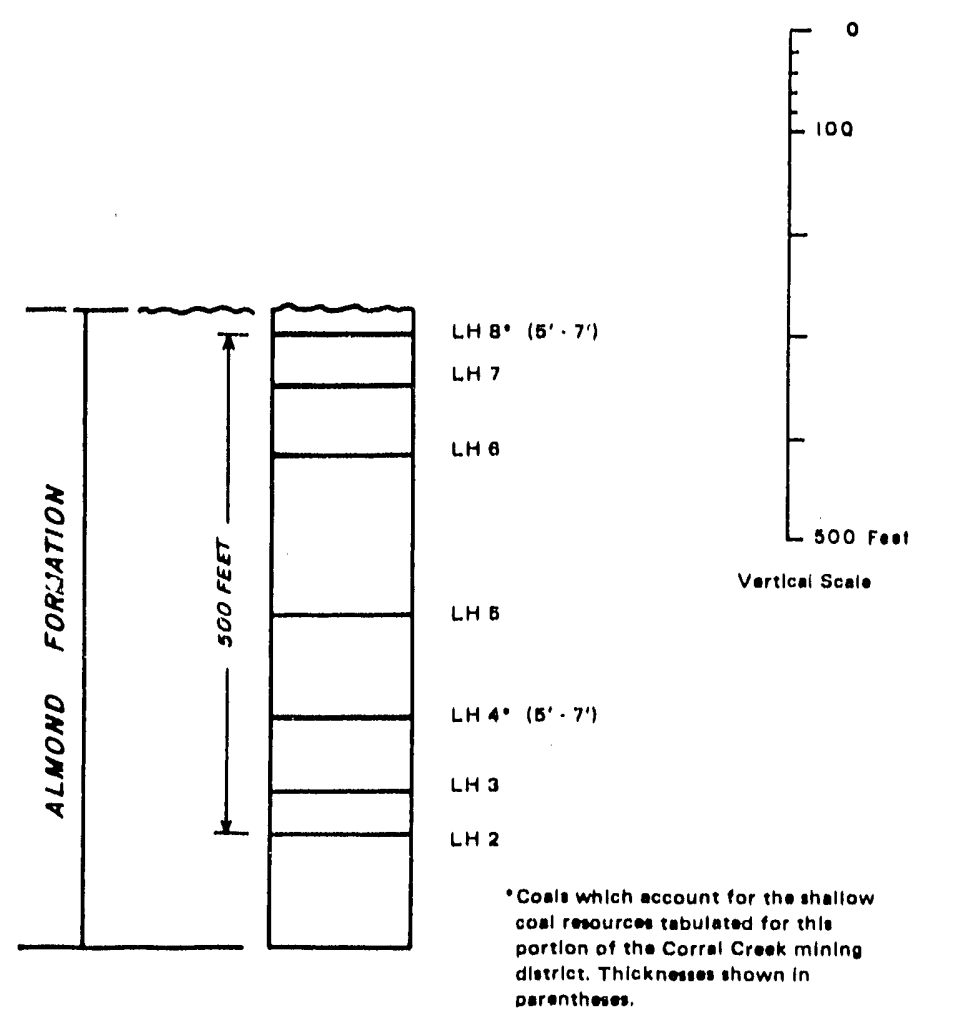

Figure 7. Coal nomenclature in the southern portion of the Corral Creek Mining District of the Hanna Coal Field (modified from U.S. Geological Survey Open-file Report 78-062) (from Glass and Roberts, 1979). 
Coal beds in the Medicine Bow Formation contain heating values in the 15.00 - 19.99 million Btu/short ton category and sulfur contents in the $0.41-0.60 \mathrm{lbs}$ sulfur/million Btu category. Only 1.08 million tons of strippable DRB coal occur in the Medicine Bow Formation. Coal beds in the Almond Formation contain higher heating contents $(20.00$ - 22.99 million Btu/short ton) but the same sulfur contents as the coal beds in the Medicine Bow Formation. About 16 million tons of strippable DRB coal occurs in the Almond Formation. No significant mining has occurred in this district so the DRB was not adjusted for production and mining losses.

5. Carbon Mining District. Strippable coal beds occur in the Hanna Formation of this mining district (Figures 8 and 9) and account for 118.86 million tons of strippable DRB in the Hanna Coal Field. Coal analyses from 30 core, channel, or tipple samples (Table 3) were used to assign sulfur and heating value categories to the reserves of eight strippable coal beds (Table 9 ). The coal beds with the lowest heating values also contain the highest amounts of sulfur. Remaining strippable reserves of 33.3 million tons of coal occur in the two highest sulfur categories. Coal with heating values of $20.00-22.99$ million Btu/short ton contain the lower sulfur coals in the mining district. Most of the coal in this heating value category contains $0.41-0.60 \mathrm{lbs}$ sulfur/million Btu.

6. Hanna Mining District. Strippable coal beds in the Hanna Formation in this district (Figures 10 and 11) account for 228.48 million tons (or 40 percent) of remaining strippable DRB in the Hanna Coal Field. Analyses from 87 core, channel, and tipple samples and about 400 coal deliveries (Table 4) were used to characterize the 23 coal beds that contain strippable coal.

Only 15.89 million tons of remaining DRB coal, in four coal beds, contain from 15.00 to 19.99 million Btu/short ton (Table 10). The other 212.59 million tons of remaining DRB coal in this district contain from 20.00 to 22.99 million Btu/short ton. This district has strippable coals that occur in all but the highest sulfur category (Tal le 10). The 0.61C.83 and the 0.84-1.67 lbs sulfur/million Btu categories contain most of the strippable DRB. Only the Hanna No. 1, Hanna No. 2, Hanna No. 5, and Bed 72 contain strippable coal reserves in the two lowest sulfur content categories.

The 273.88 million tons of remaining strippable DRB coal in the Hanna Mining District (Glass and Roberts, 1979) as of January 1,1978, has been depleted by an additional 45.40 million tons as of December 31, 1990. Coal extracted through 


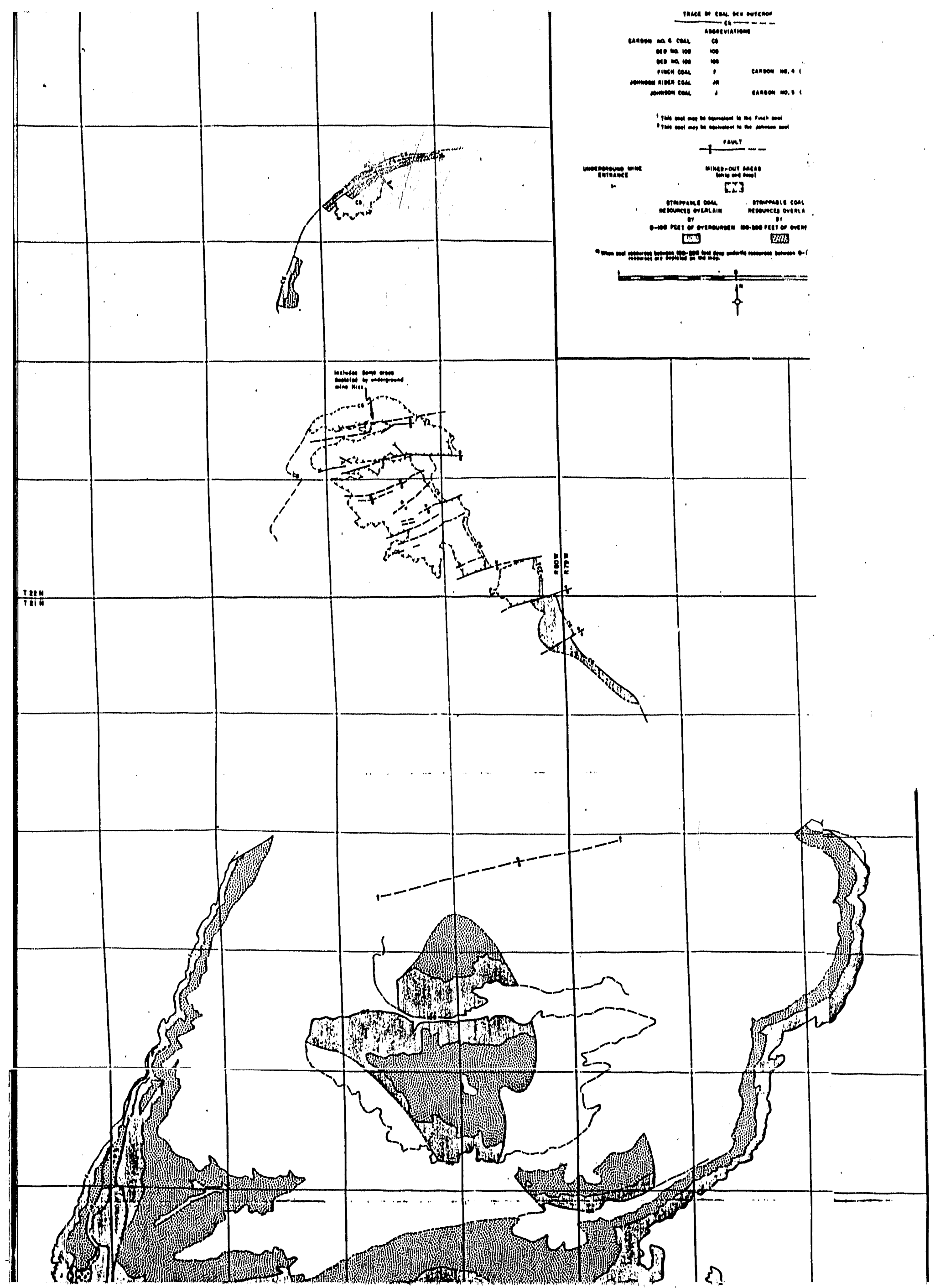




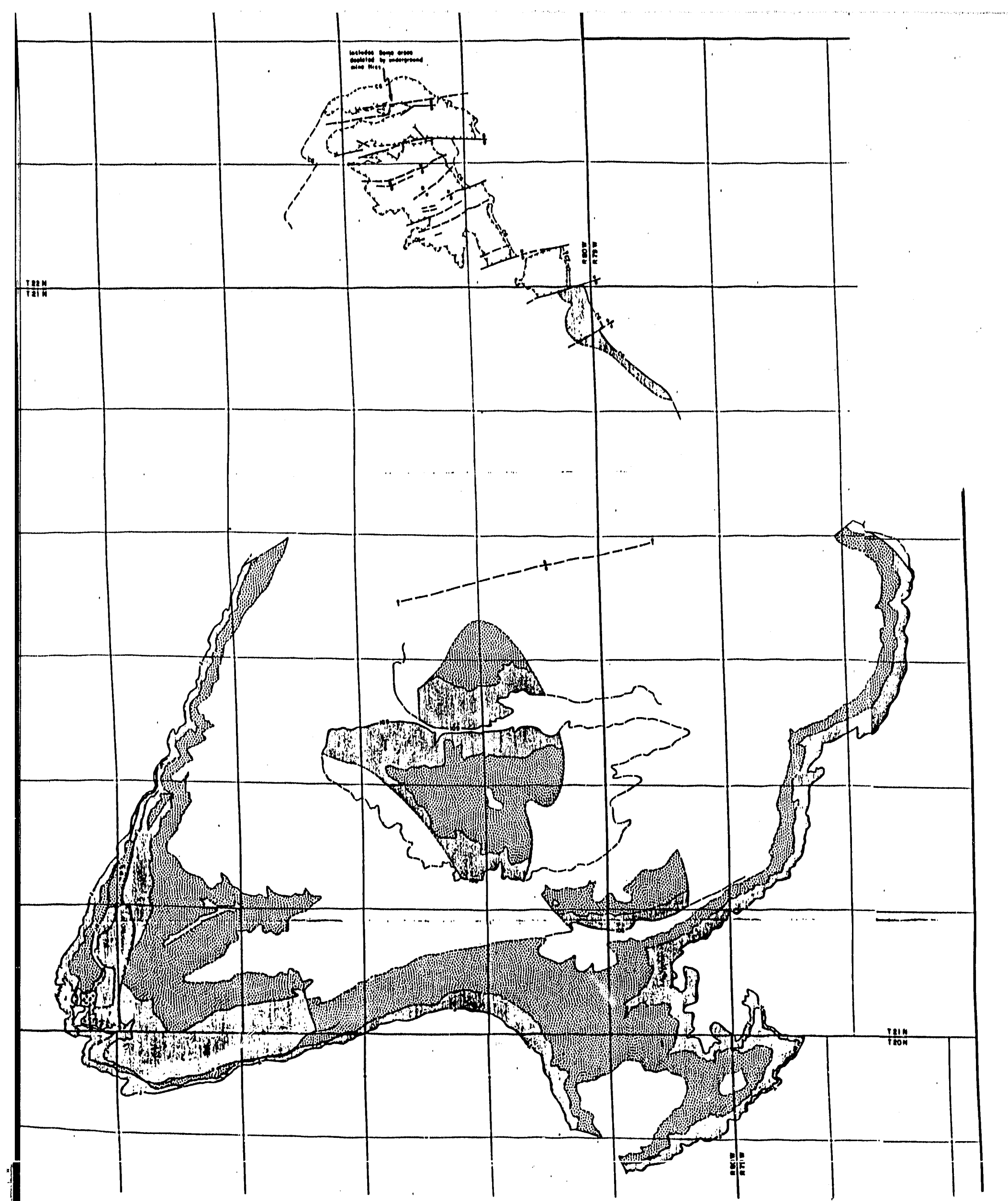

Figure 8. Location map of estimated strippable coal reserves, Carbon Mining District, Hanna Coal Field, Carbon County, Wyoming (from Plate 1 of Glass and Roberts, 1979). 


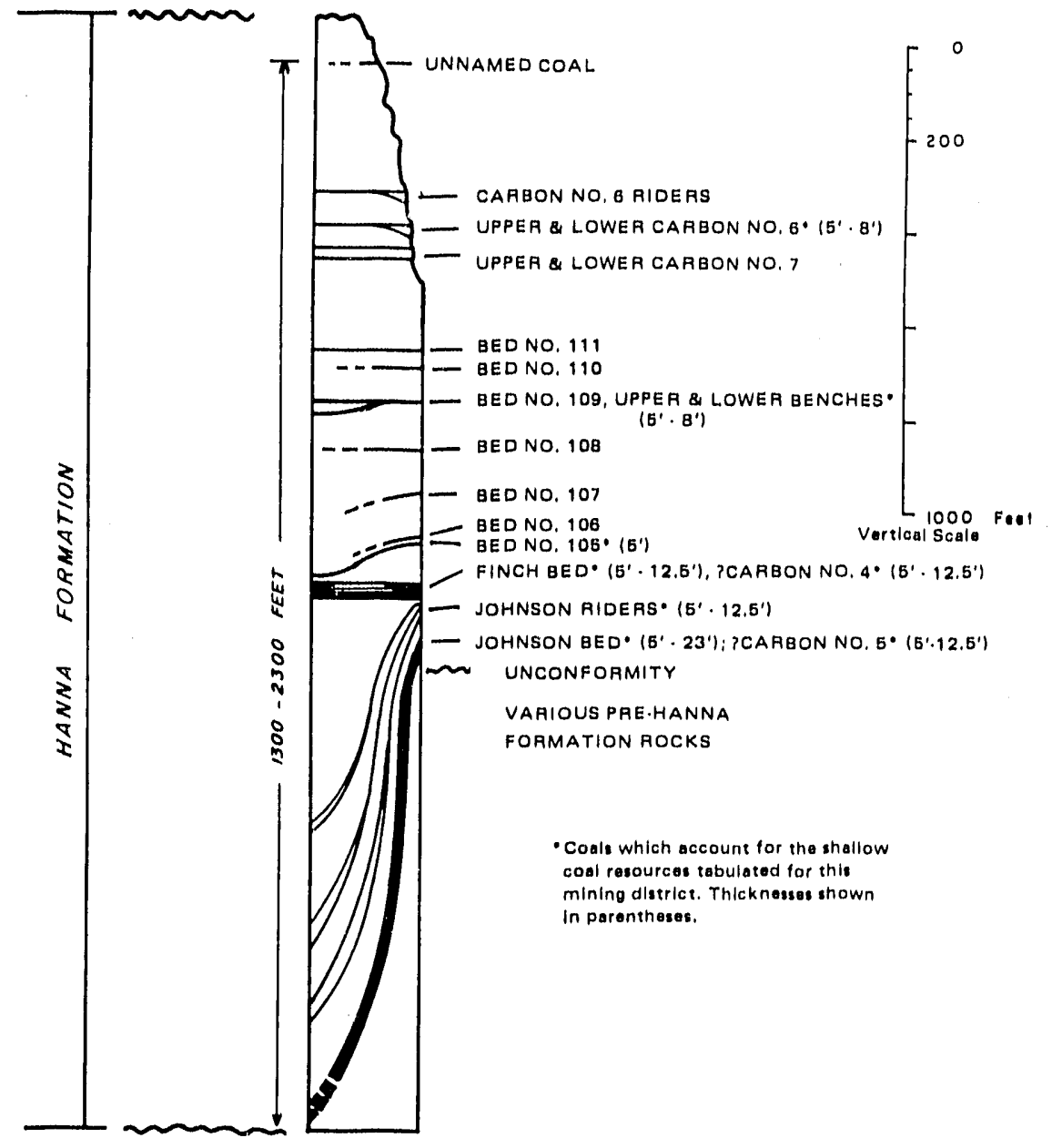

Figure 9. Coal nomenclature in the Carbon Mining District of the Hanna Coal Field (from Glass and Roberts, 1979).

underground mines in this district has not depleted these totals for strippable coal; coal analyses from some of the underground mines were used to help characterize some of the coal beds.

7. Seminoe Mining District. Strippable coal beds in the Hanna and Ferris Formations in this district (Figures 11 and 12) account for 201.6 million tons (or 35.6 percent) of the remaining strippable DRB in the Hanna Coal Field. Analyses from 79 core, channel, and tipple samples and 204 coal deliveries (Table 5) were used to characterize the 47 coal beds that contain strippable coal.

Recent coal production data reported for beds known to industry as Reds 38,52 , and 62 of the Ferris Formation were assigned to Beds 33, 53, and 61, respectively, of Glass and Roberts (1979). Production and mining losses for these beds were subtracted from original strippable reserves estimated by Glass and Roberts. 1979. 


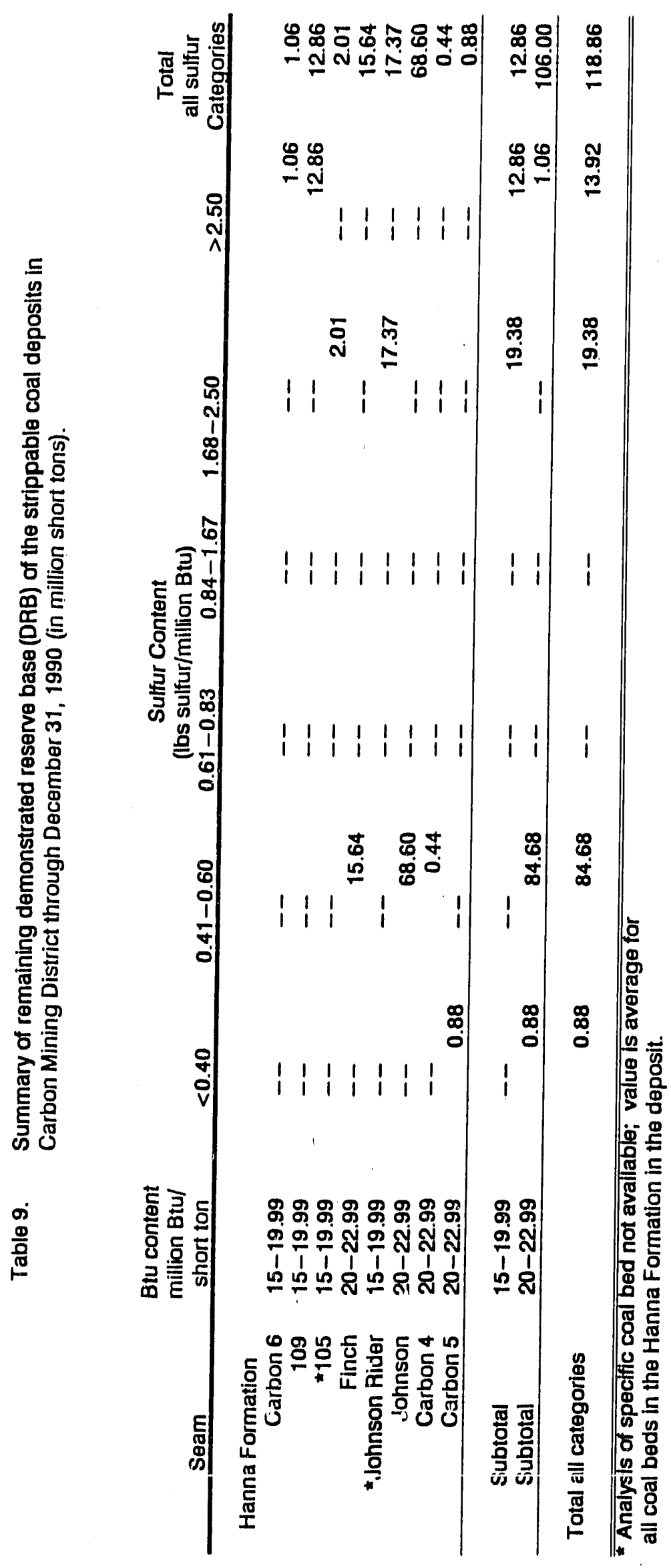




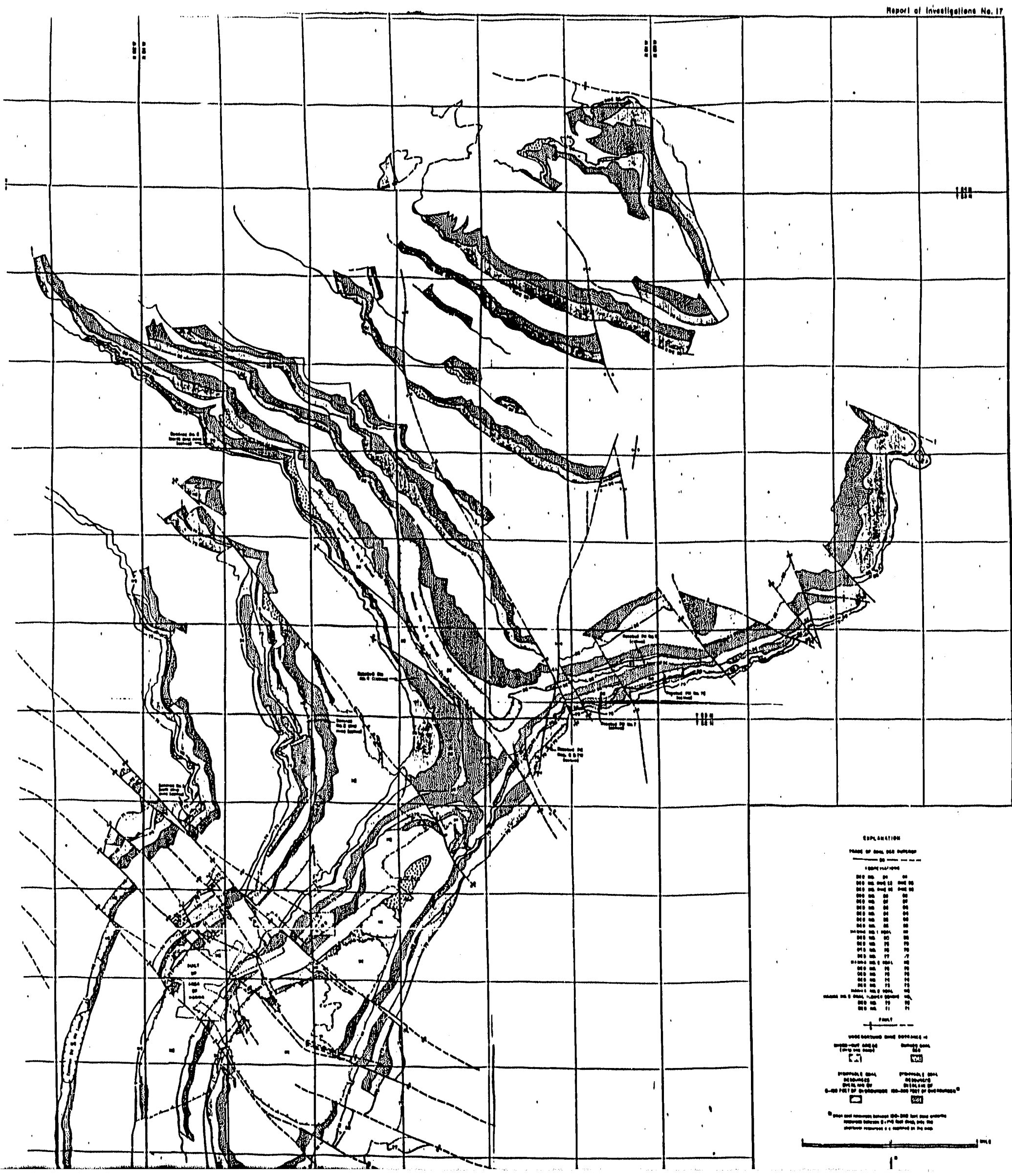


HANNA FORMATION

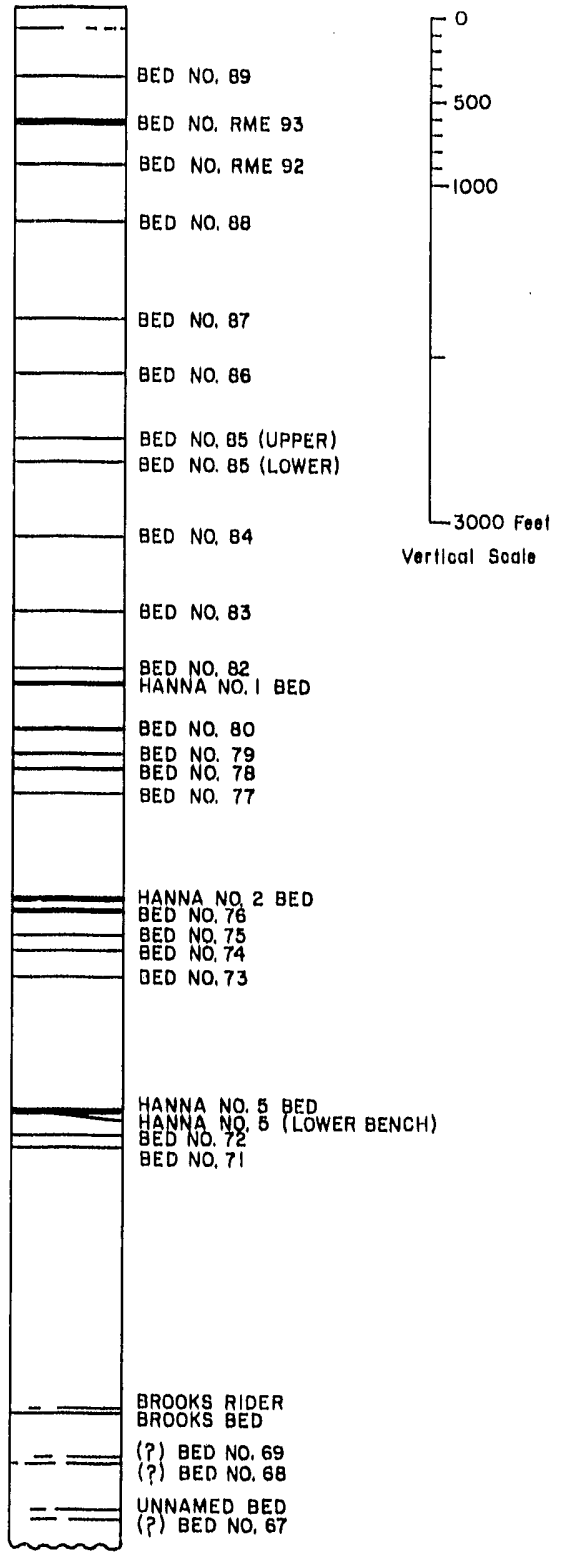

FERRIS FORMATION

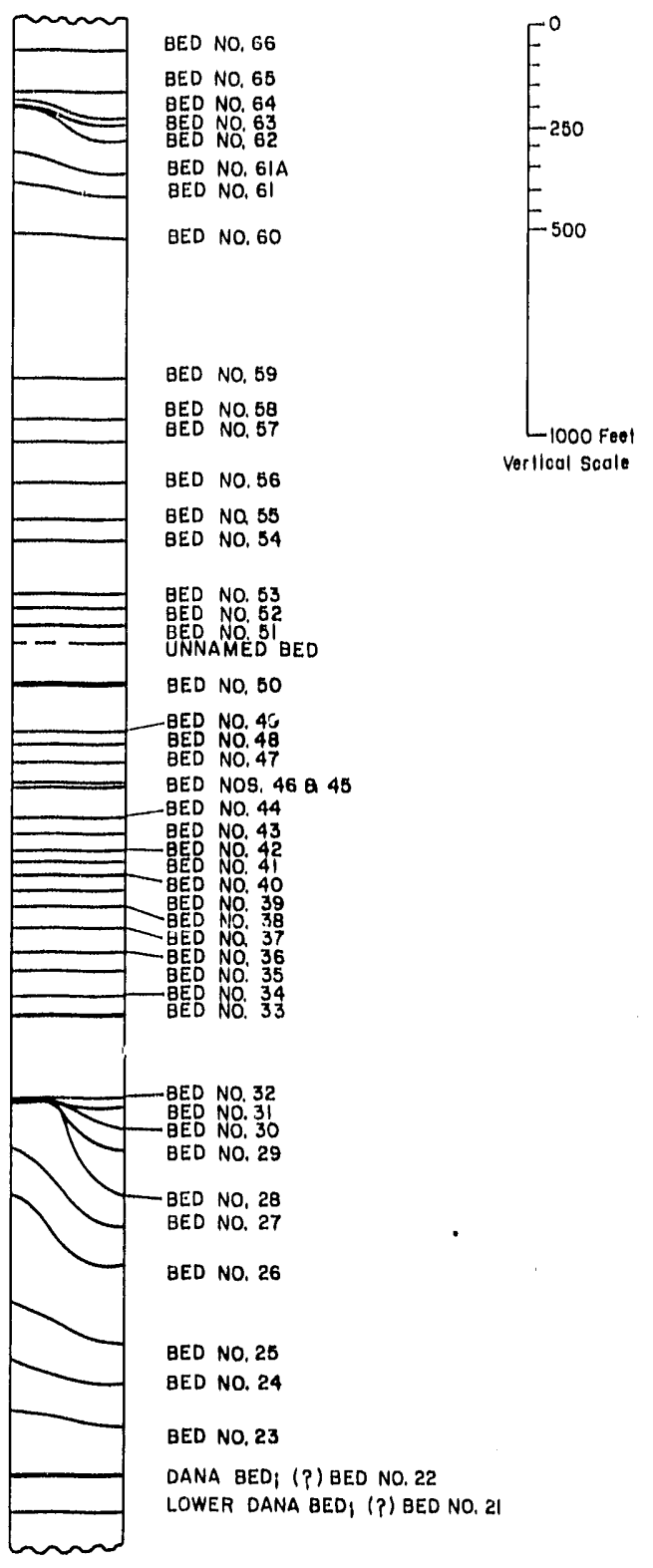

Figure 11. Coal ied nomenclature in the Hanna and Seminoe Mining Districts, Hanna Coal Field (from Glass and Roberts, 1979). 


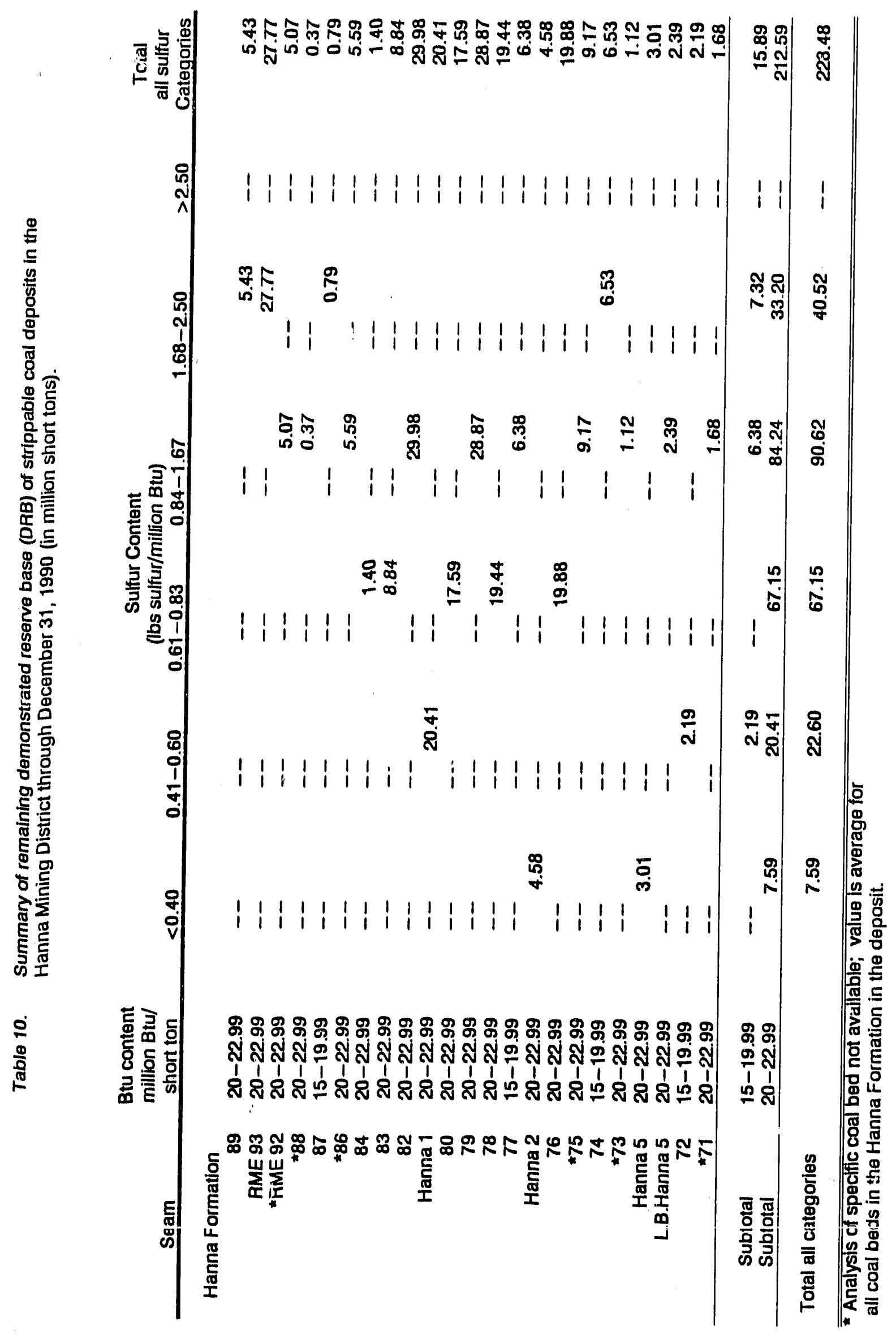




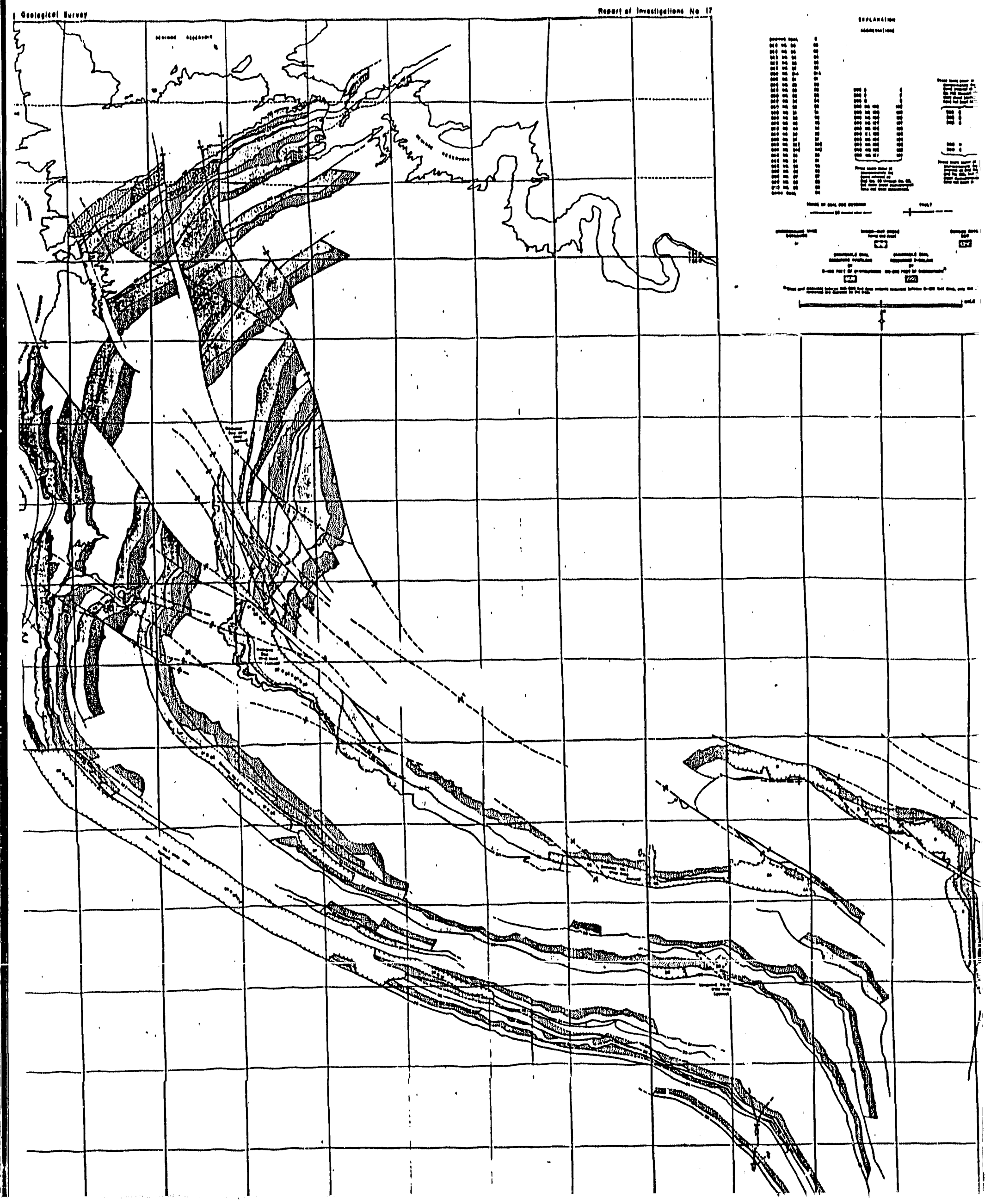




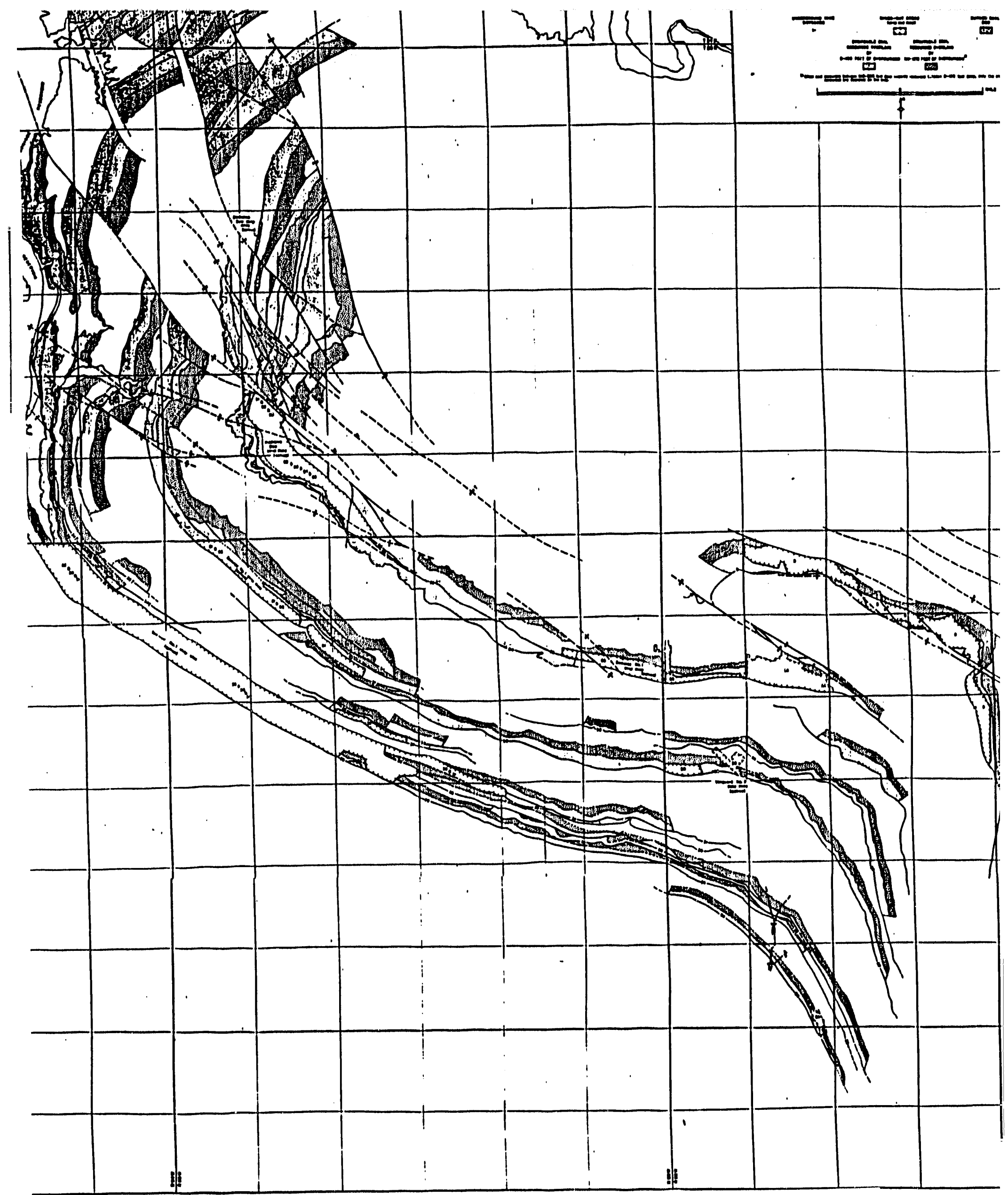

Figure 12. Location map of estimated strippable coal reserves, Seminoe Mining District, Hanna Coal Field, Carbon County, Wyoming (from P!ate 3 o! Glass and Roberts, 1979). 
The Brooks coal bed is the only strippable Hanna Formation coal in the Seminoe Mining District. This coal bed only accounts for 5.31 million tons of reserves. The remaining 196.29 million tons in the mining district occur in Ferris Formation coal beds (Table 11). Most of the strippable DRB coal in the Ferris Formation contains less than $0.60 \mathrm{lbs}$ sulfur/million Btu; only 13.41 million tons of the DRB for the Ferris Formation occurs in the higher sulfur categories. Strippable coals in the Ferris Formation occur in two heating value categories: almost 54 percent ( 105.51 million tons) of the Ferris Formation DRB contains 15.00-19.99 million Btu/short ton and about 46 percent of the Ferris Formation DRB contains 20.00-22.99 million Btu/short ton.

Glass and Roberts (1979) estimated 238.47 million tons of remaining strippable DRB coal for the Seminoe Mining District as of January 1, 1978. Production and mining losses (based on an 80 percent recovery factor) from January 1, 1978 through December 31,1990 , have depleted the strippable DRB by 36.87 million tons. The remaining strippable DRB for the Seminoe Mining District is 201.60 million tons as of December 31,1990 .

8. Grass Creek strippable deposit, Bighorn Coal Field. The only strippable coal in this field occurs in the lower 600 feet of the Fort Union Formation (Paleocene) in the southwestern part of the field (Figure 13).

Two coal beds, the Gwynn and the Mayfield, are of strippable thickness ( 4 feet thick or greater) in the area. The Gwynn coal bed ranges from 6.5 to 31.8 feet thick and averages 13.2 feet thick. The Mayfield coal bed, which overlies the Gwynn, is from 4.0 to 32.3 feet thick and averages 20.8 feet thick. The two coal beds are separated by an average interburden thickness of 140 feet. Maximum overburden on top of the Mayfield coal bed in the area is 200 feet.

Original strippable reserves of 18.6 million tons for this coal deposit were published by Glass, Westervelt, and Oviatt (1975). Production and mining losses have depleted these reserves by slightly more than 0.59 million tons. The remaining strippable DRB of 17.99 million tons of coal (Table 1B) occurs in the Mayfield and the Gwynn coal beds. Analyses from 60 core, channel and tipple samples (Table 6) were used to characterize the coal beds in this deposit. 
Table 11. Summary of remaining demonstrated reservo base (DRE) of strippable coul deposts in the 8erninoe Mining District through December 31,1990 (In million short tons).

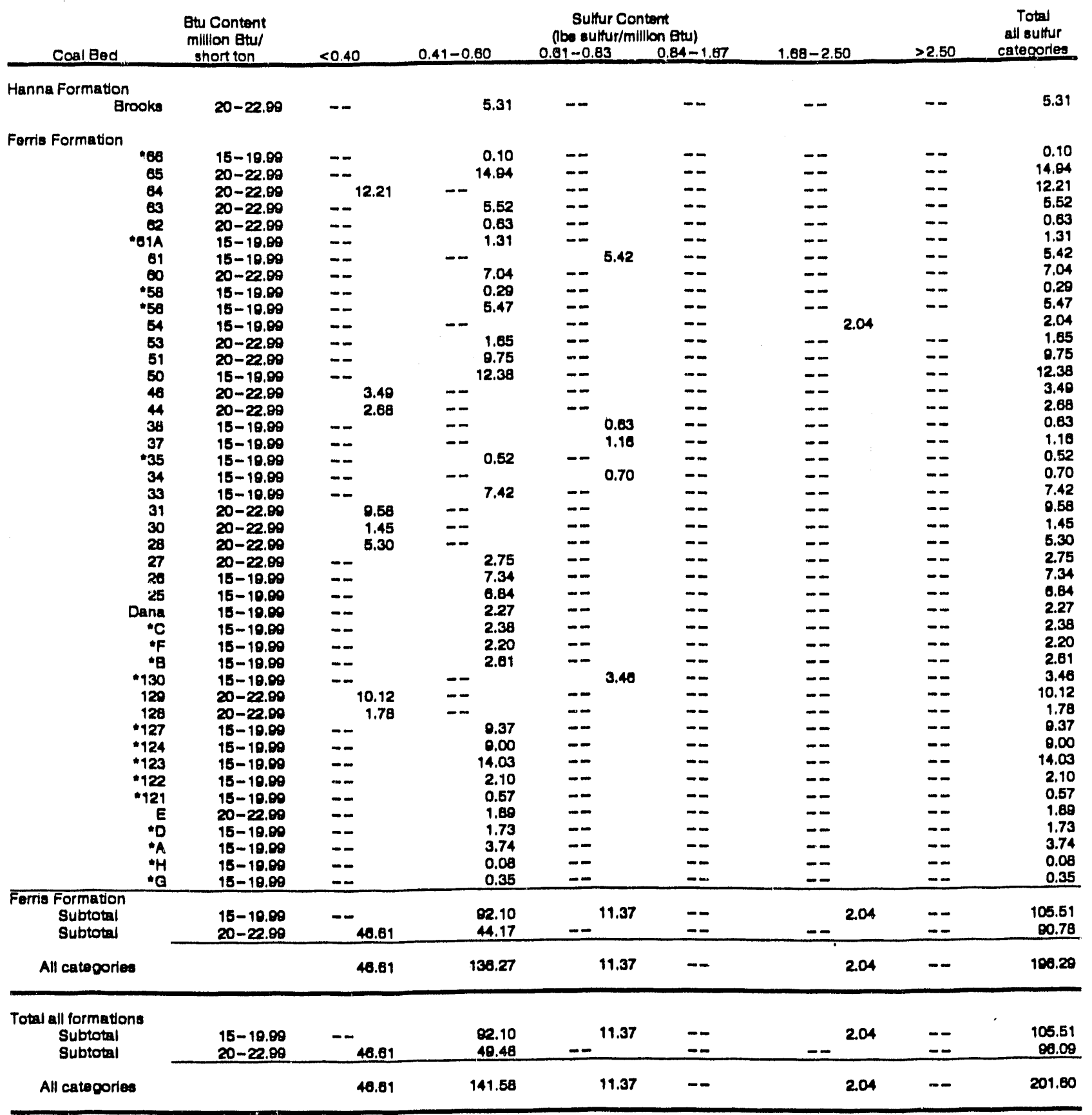

- Analyais of apectific coal bed not avallable; value la average for all coal beds in the forrie Formatton in the depoelt. 


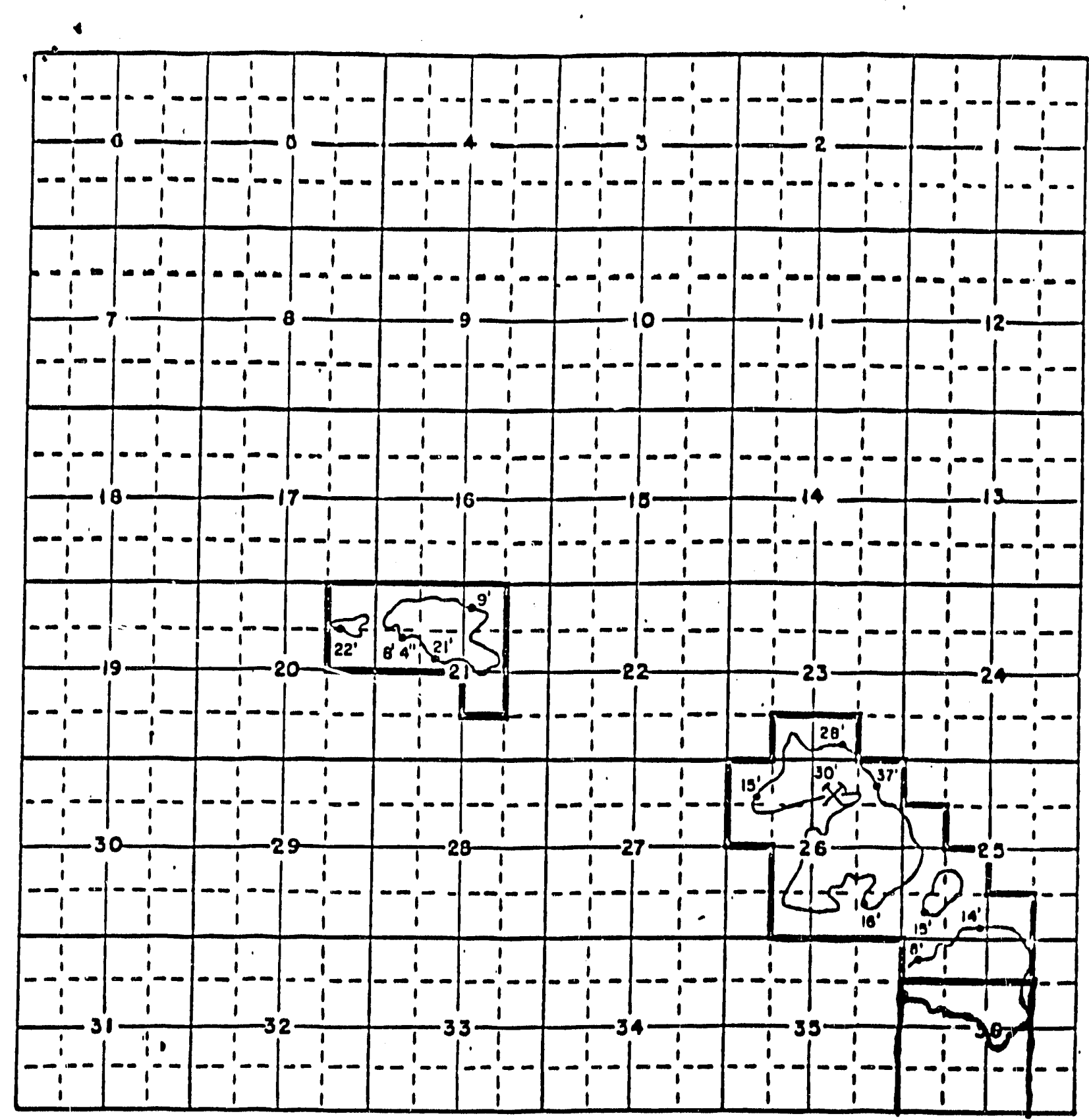

\section{GRASS CREEK KNOWN COAL LEASING AREA}

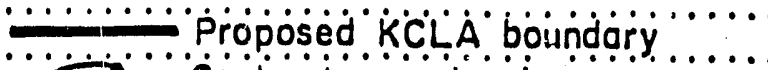

-.2! ... Cool outcrop, showing measured cool thickness

x..... Mine

$\ldots \ldots \ldots \ldots \ldots \ldots \ldots \ldots \ldots \ldots \ldots \ldots \ldots \ldots \ldots \ldots \ldots$

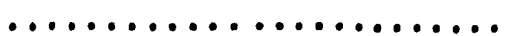

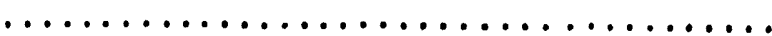

$\ldots \ldots \ldots \ldots \ldots \ldots \ldots \ldots \ldots \ldots \ldots \ldots \ldots \ldots \ldots$

Geology from u.s. Geol Survey prof.

Poper 445,926, and

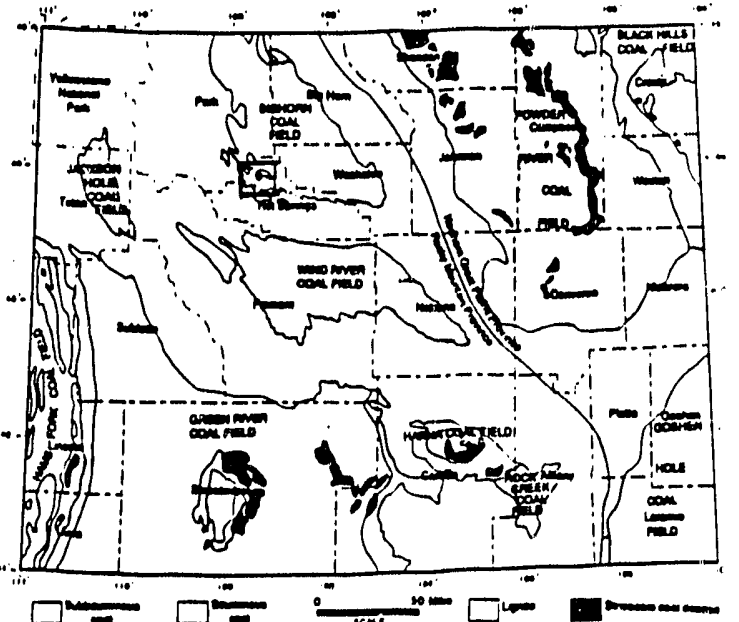

$\square^{m-10} \square=0$ ropm 0.1556

(JAM. I964)
OPO 070.102
TOHNSHIP PLAT
Figure 13. Location map of the Grass Creek strippable coal deposit, Bighorn Coal Field, Hot Springs County, Wyoming (from U.S. Geological Survey, 1974). 
The Mayfield coal bed has a weighted average heating value of 20.02 million Btu/ short ton and a weighted average sulfur content of $0.43 \mathrm{lbs}$ sulfur/million Btu. The Gwynn coal bed, which underlies the Mayfield, contains slightly less sulfur than the Mayfield and slightly higher Btu content. Because the estimates of strippable DRB for this deposit include the combined Mayfield and Gwynn coal beds, the weighted averages for both beds were combined. Coals in the Grass Creek deposit contains heating values of $20.00-22.99$ million Btu/short ton and sulfur contents of $0.41-0.60 \mathrm{lbs}$ sulfur/million Btu.

\section{REFERENCES CITED}

Glass, G.B., Westervelt, K., and Oviatt, C.G., 1975, Coal mining in the Bighorn Coal Basin of Wyoming: Wyoming Geological Association 27th Annual Field Conference Guidebook, p. 221-228.

Glass, G.B., and Roberts, J.T., 1979, Remaining strippable coal resources and strippable reserve base of the Hanna Coal Field in southcentral Wyoming: Geological Survey of Wyoming Report of Investigations No. 17, $166 \mathrm{p}$.

U.S. Geological Survey, 1974, Minutes of the Mineral Land Evaluation Committee, Grass Creek Known Coal Leasing Area, Hot Springs County, Wyoming: Wyoming Coal Land I easing Minutes, No. 5, 6 p. 


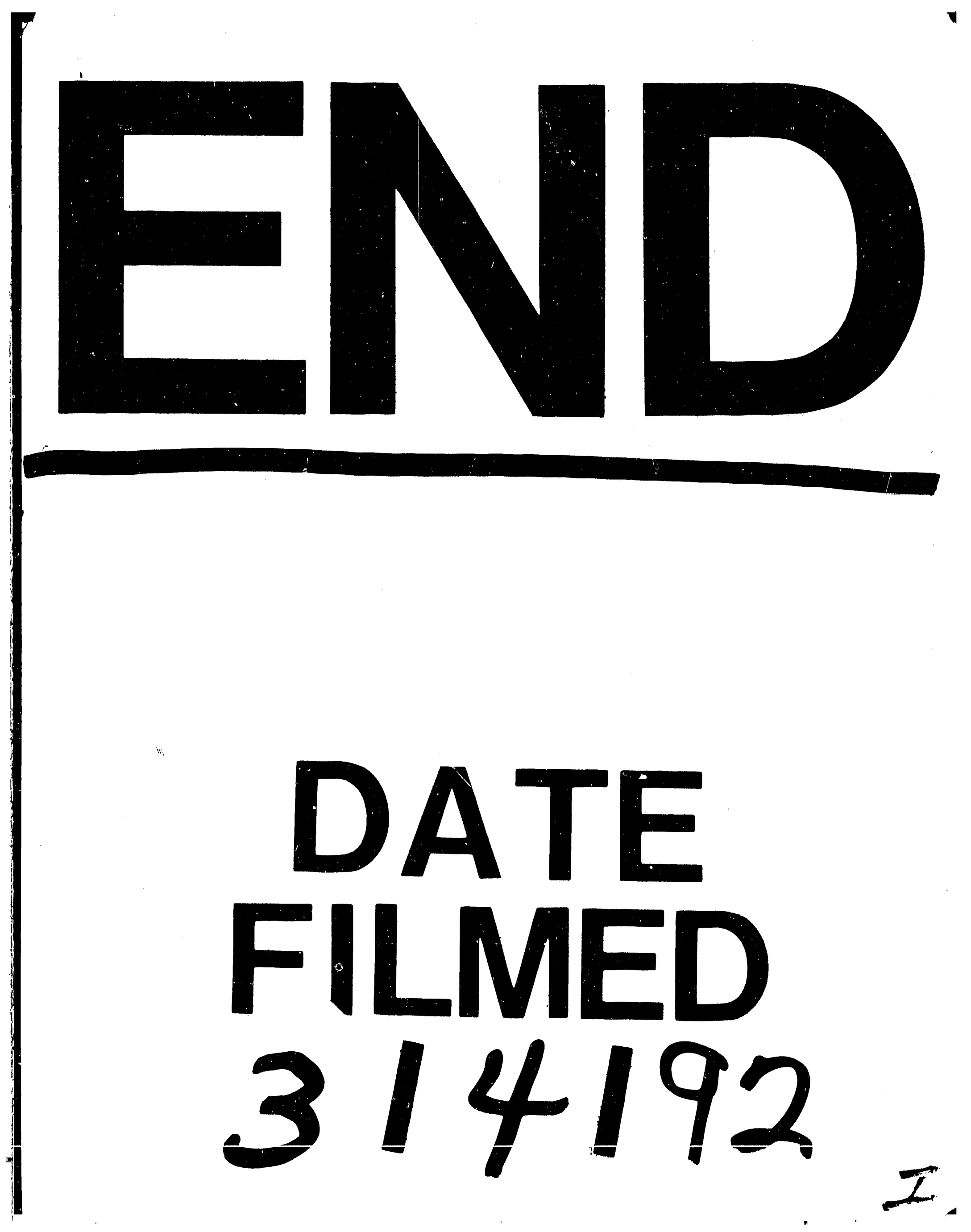



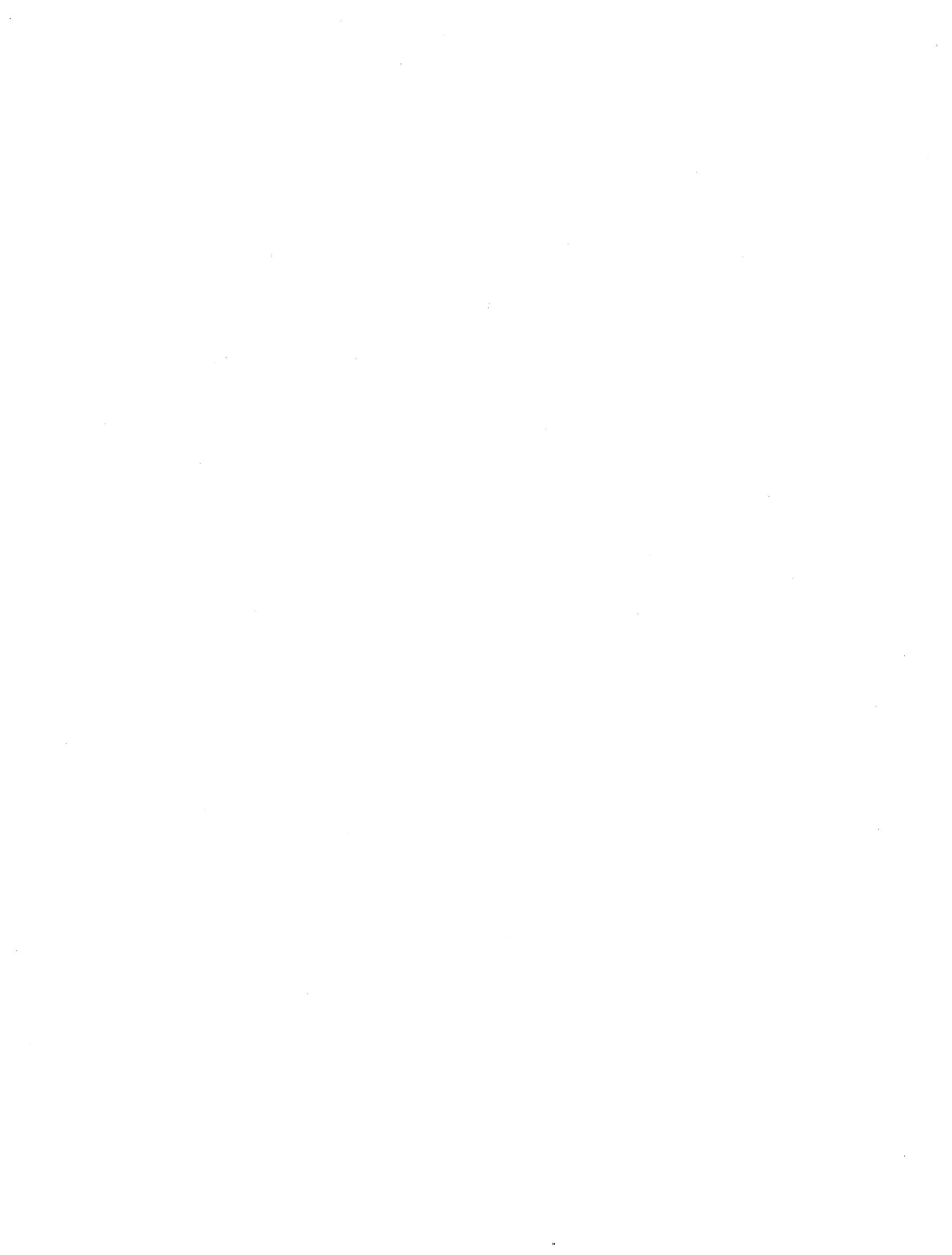